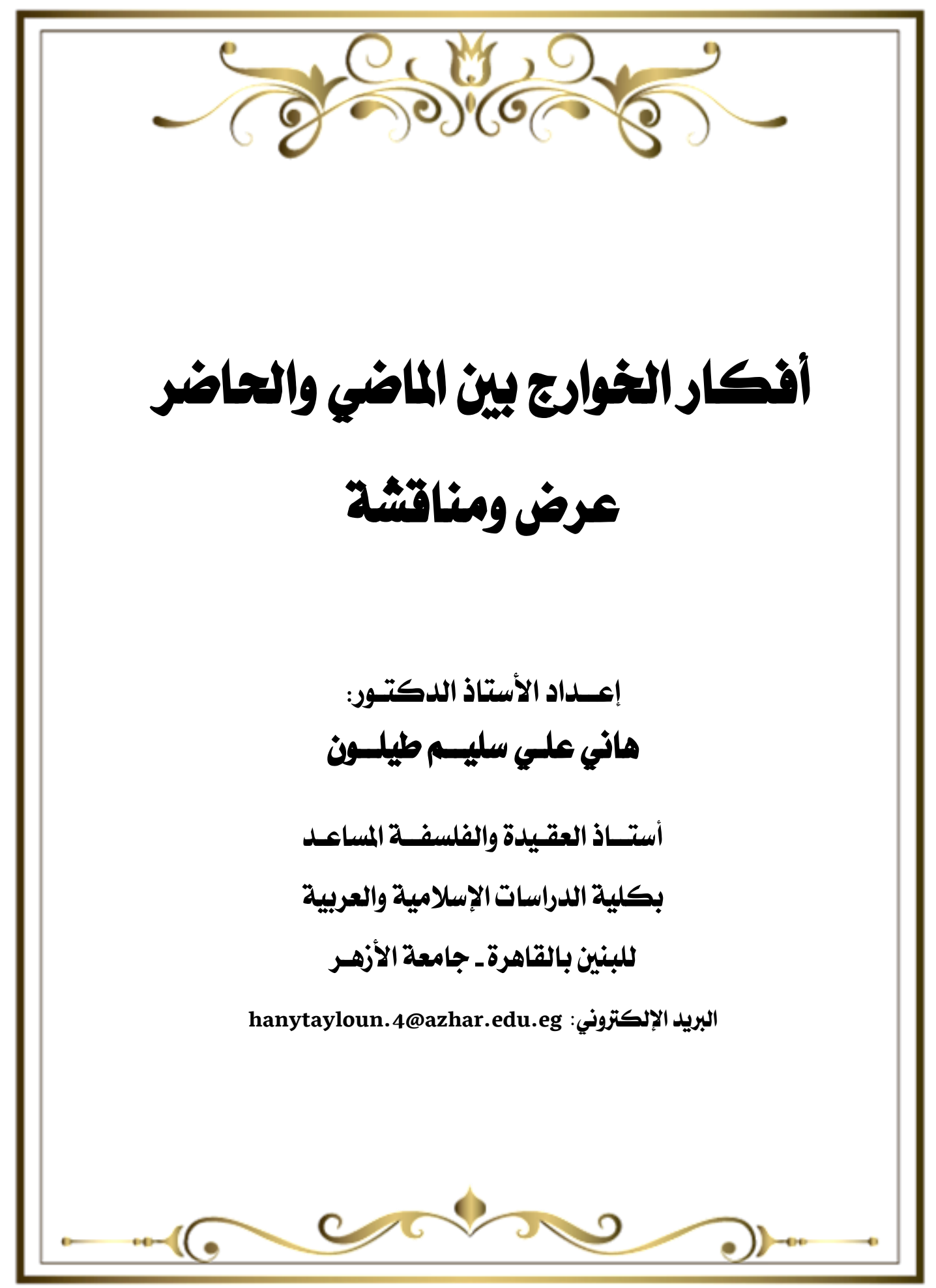


المجلد السابع والثلاثثن إصدار ديسمبر 19.rم م م

गิे

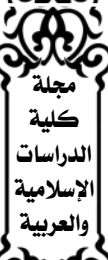

- 255

osec 
با
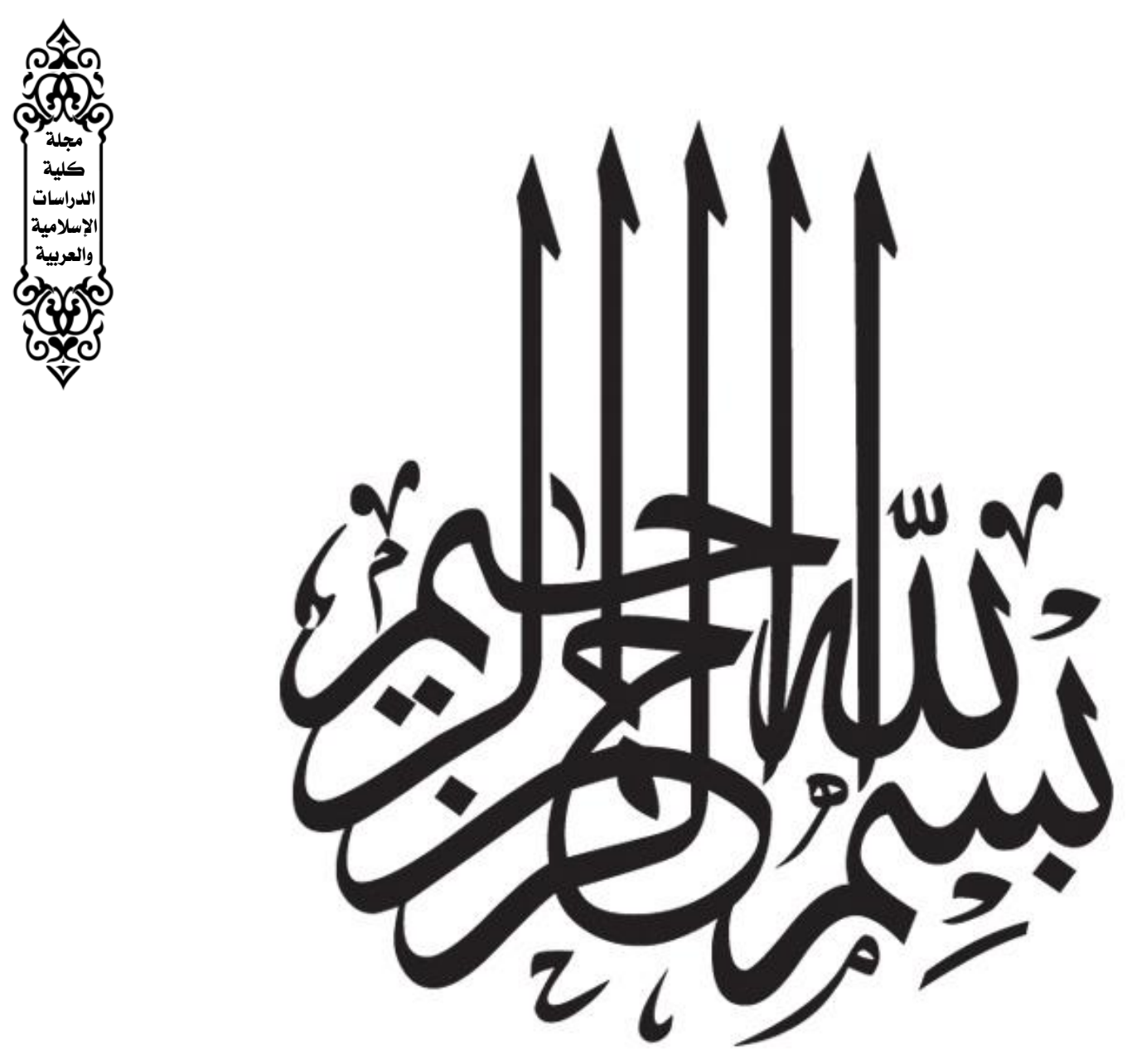
المجلد السابع والثلاثثن إصدار ديسمبر 19.rم م م

गิे

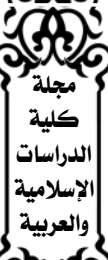

- 255

osec 


\section{ملخص البحـــــ}

تعد فرقة الخوارج من أوائل الفرق الإســلامية ظهورًا في تأريخ الإسـلام، بعقائدها المنحرفة، وأفكارها الثـاذة، كما أنهم ليسـوا حقبة تاريخية قد مضــت و انتهت بآثارها السـلبية المدمرة،

لتُدرس على أنها ظاهرة تاريخية فحسـب، لا وجود لهم في الواقع، بل هم بأفكارهم وآرائهم المنحرفة الشاذة باقون متجددون عبر القرون، كلما ذهب منهم قرن نبت قرن آخر، وتظهر أهمية هذا الموضـوع في كثرة ما وَرَدَ عنهم من أحاديث نبوية، بل ربما لم يرد في السـنة النبوية من الأحاديث المحذرة والمبينة لفرقة من الفرق مثلما ورد في شـأن الخوارج، ويرجع اختياري لهذا الموضسوع من أجل خفاء حال الخوارج المتأخرين على كثير من الناس، وظهور وانتشار أفكار التكفير والتطرف والغلو في مجتمعاتنا الإســلامية، والثــدة والغلظة في معاملة المســلمين مع بعضهم، والتحذير لعموم المسلمين من مسالك الخوارج وطرقهم و أفكارهم.

وقد اشتمل هذا البحث على التعريف بالخوارج وفرقهم وأفكارهم، من التكفير والغلو والشدة والغلظة والميل إلى الجدل، وكيفية علاج هذه الظواهر وتلك الأفكار، وبيان وسـطية الإسـلام، وموقفه من هذه الظواهر، ومن أهم نتائج البحث: أن الخوارج هم الذين خرجوا على الإمام على - رضي الله عنه - بعد قبوله التحكيم في موقعة صفين، ومن وافقهم ورأى آرائهم من الناس إلى يوم الدين فهو منهم، وأن هناك عدد من الأصول والقواسم المشتركة التي اجتمع عليها عامة الخوارج من أهمها: الخروج على الإمام الجائر، ورفض التحكيم، وتكفير مرتكب الكبيرة، وأن فرقة الخوارج قد جنحت نحو الثــدة والغلظة، مبتعدة عن نصـوص الثــــع التي تأمر بالرفق والرحمة، وأن الوسطية هي إحدى الخصائص العامة للإسلام، وإحدى المعالم الأساسية التي

$$
\text { ميز الله - تعالى - بها أمة الإسلام عن غيرها من الأمم. }
$$

الكلمـات المفتاحيــة: الخـــوارج - التكفيــر - الغلــو - الغلظـــة - الثـــدة - الجـــل الوسطية. 


\section{The Ideas of the Kharijites (Dissenters) in between the Past and Present Times; A Presentation and Exposition}

By: Hany Ali Saleem Tailoun

Assistant Professor of Philosophy and Doctrine

Faculty of Islamic and Arabic Studies for Men in Cairo

Azhar University

E.MAIL: hanytayloun.4@azhar.edu.eg

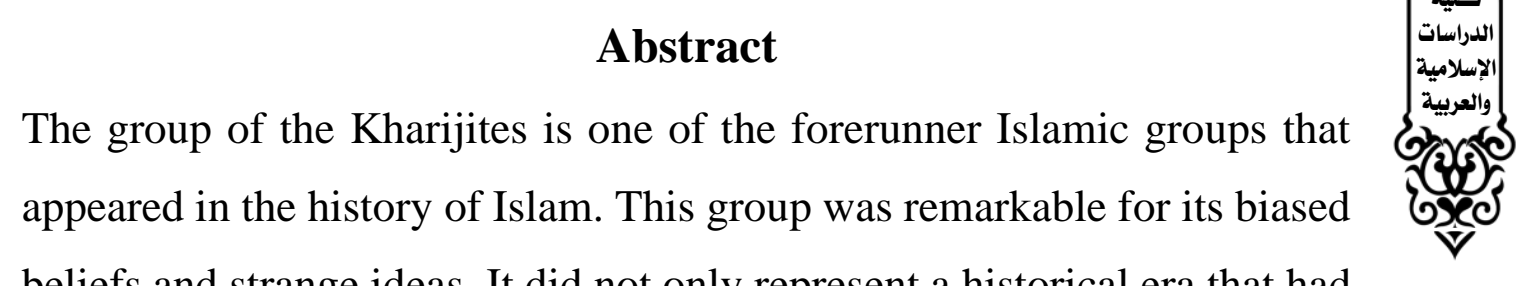
beliefs and strange ideas. It did not only represent a historical era that had gone away with its destructive consequences but it also represents a group that still exists in reality accompanied by its irregular beliefs and bizarre ideas which continue to appear along centuries. Whenever a century passes away a new century follows with this group at the center. The importance of this topic can be traced back to the great number of inherited Prophetic traditions which warned the Muslims against this group; namely the Kharijites. The reason why the researcher has chosen this topic is to clarify the underlying late Kharijites before the majority of people. In addition, radical, infidel and extreme ideas have spread in our Muslim societies as well as the tough and coarse treatment of the Muslims with their fellow Muslims. Moreover, the research aims at warning the publicity of Muslims against the ideas and ways of the Kharijites. The research at hand is keen to define the Kharijites, their groups and their ideas such as blasphemy, extremism, exaggeration, roughness, serenity and controversy. The research tries also to treat these phenomena and ideas as 
well as displaying the moderation of Islam and how these phenomena are judged in the light of its approach. Some of the most important findings of this research are stated in the conclusion. For example, the Kharijites are those who dissented from the rule of Imam Ali (May Allah be pleased with him) after his acceptance of the judgment in the battle of Seffin, and those who agree with them joined them to the Day of Judgment. The Kharijites have shared some of the basic principles such as disagreeing with the unjust ruler and refusing judgment, accusing those who commit major sins of being blasphemous. In addition, the Kharijites intended to be serene and rough though the Muslim doctrine told us to be kind and sympathetic. Moderation is one of the general characteristics of Islam and it is also one of the basic attributes that characterize the Muslims rather than any other nation.

Key words: the Kharijites, accusing one of being blasphemous, serenity, roughness, extremism, controversy, moderation. 


\section{ســـالهُالرحمن الرحيـم}

\section{الاقدمـــة}

إن الحمد لله، نحمده ونستعينه ونستغفره، ونعوذ بالله من شـرور أنفسـنا وسيئات أعمالنا، من يهده الله فلا مضـل له، ومن يضــل فلا هادى له، وأشـــهد أن لا إله إلا الله وحده لا شــريك له، وأشـهـد أن سـيدنا ونبينا وحبيبنا وقدوتنا ومعلمنا محمدًا رسـول الله، أرسـله بالهدى ودين الحق الحق ليظهره على الدين كله، وكفى بالله شـهيدًا، فاللهم صـل وسـلم وبارك عليه وعلى آله وصسحبه ومن اهتدى بهديه إلى يوم الدين، وبعد،،،

شـاء الله - تعالى - لهذه الأمة أن تكون خير أمة أخرجت للناس، واقتضـت حكمته - سبحانه - أن تتباين فيها الوجهات وتختلف فيها المنازع وتتعدد الآراء، فمن يتأمل في الواقع الذي تعيشه الأمّة اليوم يرى بَوْنًا شـاسعًا في مشـاربها وأهدافها، واختلافًا في منطلقاتها وغاياتها، يرى الإفراط والتفريط، والغلوّ والجفاء، والإسراف والتقتير. ووسط هذا الواقع المؤلم، والاضطر اب المهلك، تشـتدّ الحاجة إلى دلالة الأمّة إلى الصّر اط المسـتقيم، والمنهج العدل المبين، لإنقاذها من كبوتها، وإيقاظها من رقدتها، وتبصـير الدّعاة

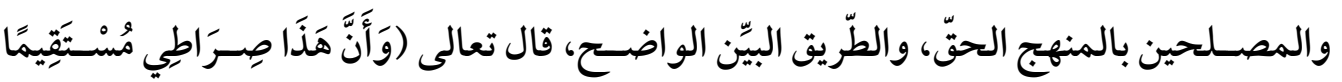

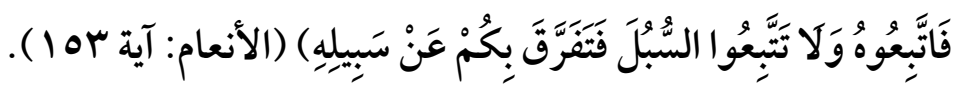

وانطلاقًا من هذا أحببت واخترت الكتابة في هذا الموضوع (أفكار الخوارج بين الماضبي والحاضر: عرض ومناقشة)، حيث إن الخوارج من الفرق المنتسبة إلى الإسلام، وهي أول الفرق الإسلامية ظهورًا في تأريخ الإسلام، بعقائدها المنحرفة، وأفكارها الشاذة، وخروجها على الأمة بالسيف. كما أن الخوارج ليسوا حقبة تاريخية قد مضـت وانتهت بآثارها السلبية المدمرة، لتُدرس على 
أنها ظاهرة تاريخية فحسب، لا وجود لهم في الواقع، بل هم بأفكارهم وآرائهم المنحرفة الشاذة باقون متجددون عبر القرون، كلما ذهب منهم قرن نبت قرن آخر، إلى أن يظهر فيهم المسـيح الدجال، كما جاء في الحديث عن سيدنا رسول الله - مئس

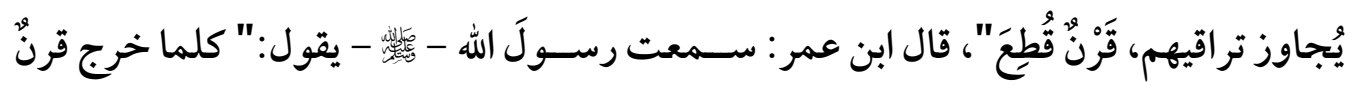

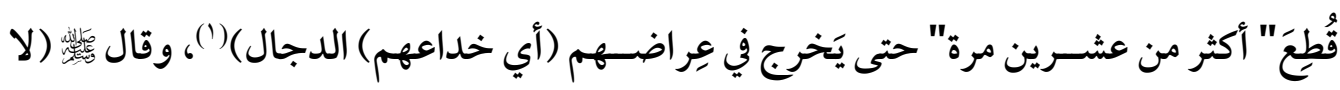
يزالون يخر جون حتى يخرج آخرهم مع الدجال) (「).

وأهمية هذا الموضــوع تظهر جليًا في كثرة ماوَرَدَ عنهم من أحاديث نبوية، بل ربما لم يرد في السنة النبوية من الأحاديث المحذرة والمبينة لفرقة من الفرق مثلما ورد في شأن الخوارج، حيث حذر الرسول - حَّل - منهم، وبيّن في أحاديثه صفاتهم و أفكارهم بتفصيل ملفت للنظر، ووصفهم

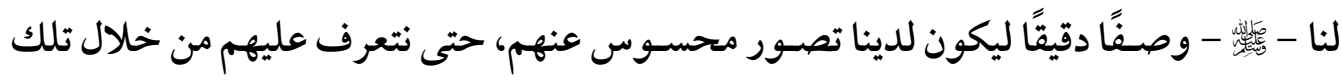
الصفات، فنحتاط منهم، ونقف لهم ولأفكارهم وآرائهم المنحرفة بالمرصاد. بل إن اتصـاف هؤلاء الخوارج بصـفات التعبد، من كثرة الصسيام والصـلاة وقر اءة القرآن ربما يغري بعض الناس فيحسـنوا الظن بهم إحســانًا يدفعهم إلى اعتقاد صـحة أفكارهم وأعمالهم،

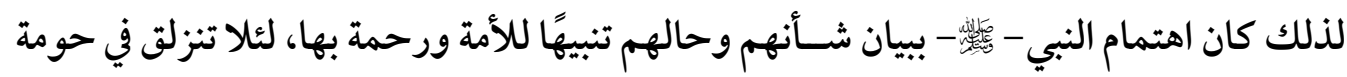

(1) أخرجه الإمام ابن ماجه في سـننه، باب في ذكر الخوارج، حديث رقم ع ل ا ، وإسـناده صسحيح، وقد احتج

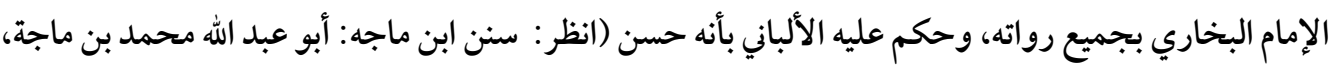

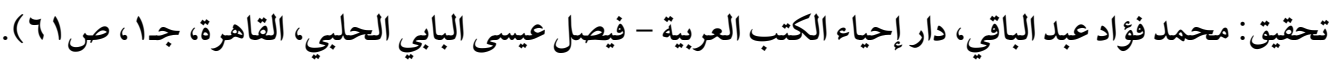

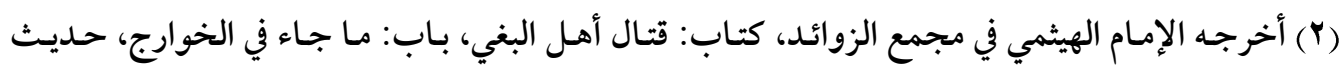
رقم4 · ـ • ا، وقال: فيه الأزرق بن قيس وثقه ابن حبان، وبقية رجاله رجال الصسحيح (انظر : مجمع الزوائد

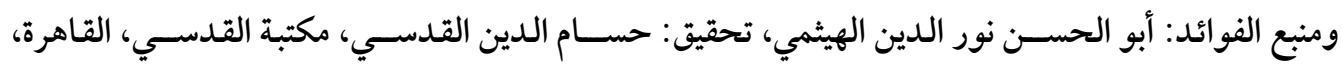
(YYq). 
أفكارهم وسوء فعالهم.

ومن ثم فإن الحديث عن فرقة الخوارج وأفكارها في هذه الأيام هو حديث عن ماضٍ مؤلم، أضــاعت فيه هذه الفرقة الطاغية - بأفكارها ومعتقداتها المنحرفة الثــاذة - من دماء الأبرياء وحياة الأتقياء وأموال المسلمين ما لا يُحصيه إلاً الله سبحانه وتعالى، وصرفت الخلافة عن قتال أعداء الله والمسلمين إلى دفع شرورهم والتصدّي لهم. لذلك كله جاء هذا البحث - المتواضـع - والذي أتمنى أن يكون لبنة في بناء دراســات تالية للتصـــي لمثل هذه الأفكار الثـاذة المنحرفة، والتي لا تمت إلى الإسـلام بأي صـلة، ولتسـلط الضـوء أيضًا على منهج الوسـطية والاعتدال الذي ارتضــاه المولى - عز وجل - منهجًا للأمة

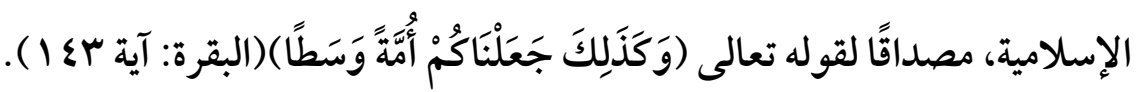
اسباب اختيار الموضوع: يمكن إجمال أسباب اختيار هذا الموضوع في الأمور التالية: - خفاء حال الخوارج المتأخرين على كثير من الناس، واشتباه أمرهم. - ظهور وانتشـار أفكار التكفير والتطرف والغلو في مجتمعاتنا الإسـلامية، والثــدة والغلظة في معاملة المسلمين مع بعضهم. - بيان أن الوسطية هي إحدى الخصـائص العامة للإسـلام، وإحدى المعالم الأسـاسية التي ميز الله - تعالى - بها أمة النبي - لَّل - عن غيرها من الأمم. - التحذير لعموم المسلمين من مسالك الخوارج وطرقهم وأفكارهم. - البر اءة مما عليه غلاة الخوارج من أفكار منحرفة لا صـلة لها بالإســلام، وإيضــاح البعد بين طريقتهم وطريقة أهل السنة والجماعة. 
أنكار الغوارج بين الماضي والحاضر عرض ومناقشئ

خطالة البجثث:

هذا وقد اشــتمل هذا البحث المتواضــع على مقدمة وثلاثة مباحث وخاتمة، أما المقلملة فهي تدور حول أهمية هذا الموضوع، وأسباب اختياره، وخطة البحث. وأما المبحث الأول: فعنولنه: التصريفـ بالخوارج وفرقهم وأفكارهم، وفيه ثلاثة مطالب: المطلب

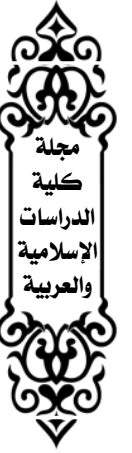

الأول: تعريف الخوارج ونشـأتهم، المطلب الثاني: ألقابهم وفرقهم، المطلب الثالث: القواسـم المشتر كة بينهم. أما المبحث الثُاذي: فعنوانه: أفكار الخوارج بيز الماضبي والحاضر، وفيه أربعة مطالب: المطلب الأول: ظاهرة التكفير، المطلب الثاني: ظاهرة الغلو، المطلب الثالث: ظاهرة الشدة والغلظة، المطلب الرابع: ظاهرة الجدل وميلهم إليه وقوتهم فيه. وأما المبحث الثُالث: فجاء بعنوان: وسطية الإسلام. وأما الغاتمة: فذكرت فيها أهم النتائج التي توصلت إليها من خلال موضوع البحث. 


\section{البحث الأول}

التعريغ بالفوادج وفر تهد وأنكار هم

وفيه ثلاثة مطالب:

المطاب الأول : تعريف الخوارج ونشأتهي

المطلب الثاني: ألقابهم وفرقهم

المطلب الثالث: المبادئ العامة للخو ارج 


\section{المطالب الأول}

\section{تعريف الخوارج ونشأته}

\section{الخوارج لغة:}

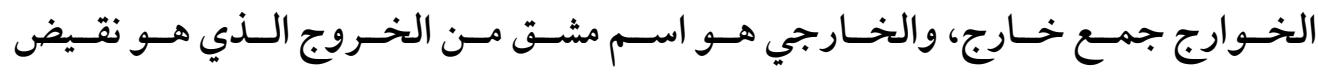

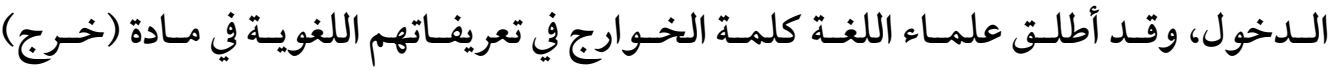
علـى هـذه الطائفــة مـن النـاس، معللـين ذلـك بخــروجهم عـن الــين، أو علـى الإمـام على، أو لخروجهم على الناس.

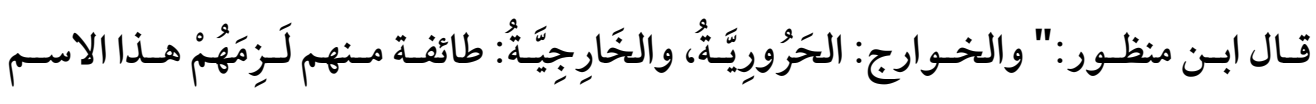

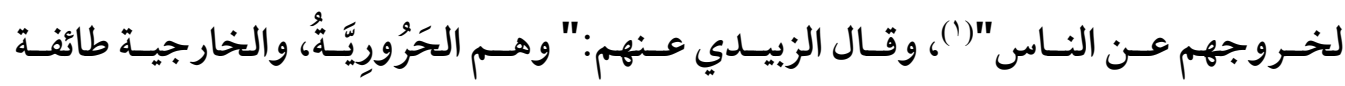

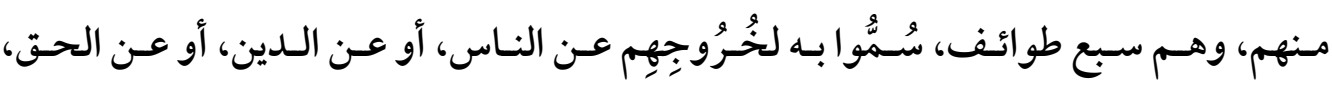

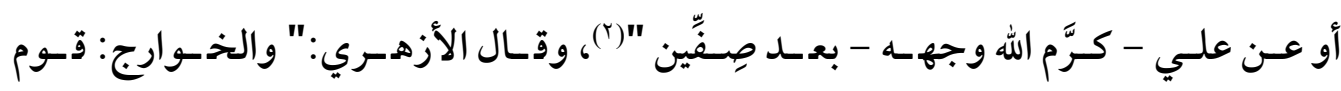

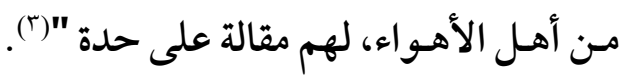

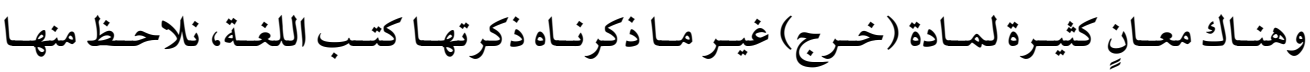
التناسـب الكبيـر بـين معنـى الخـروج في اللغـة ومـا عليـه مـنهج الخـوارج، إذ إنهـم خــارجون على أئمة المسلمين وجماعتهم، وعلى عقيدة الإسلام.

\section{الخوارج اصطلامًا:}

اختلف العلمـاء في التعريف الاصــطلاحي للخوارج، فمنهم من قـال بـأن الخوارج: هم من

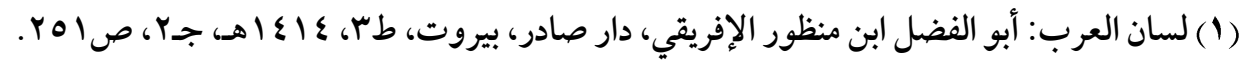

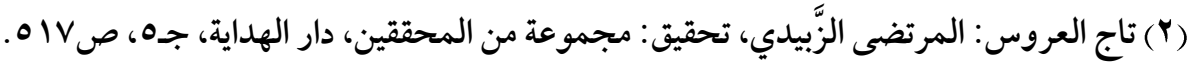

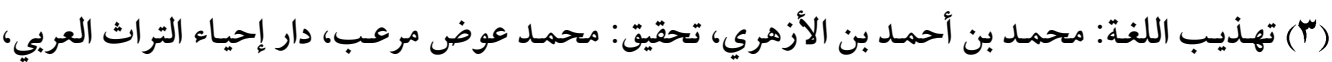

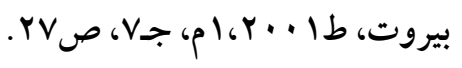


خرجوا على الإمام المســلم المتَّقق على إمامته الثــــعية في أي زمان كان، وهذا رأي الإمام الشهرستاني وغيره.

فقد ذهب الإمام الثــهرسـتاني إلى أن الخوارج هـ:" كل من خرج على الإمام الحق الذي

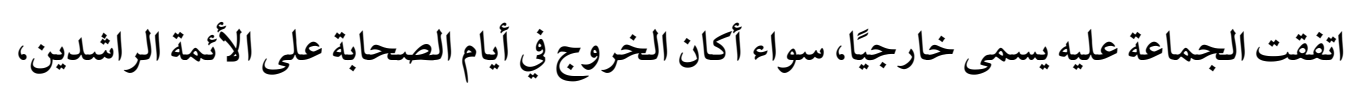
أو كان بعدهم على التابعين بإحسان والأئمة في كل زمان "((). وما ذكره الإمام الثــهرسـتاني هو تعريف عام للخوارج، اعتبر الخارجي: كل من خرج على الإمام الحق المتفق على إمامته في أي زمن كان، ولا شــك أن هذا التعريف يتناســب مع لفظة الخارج، ويدخل فيه سـلف الخوارج الذين كانوا قبل تكوين فرقة الخوارج بأصسولها المعروفة،

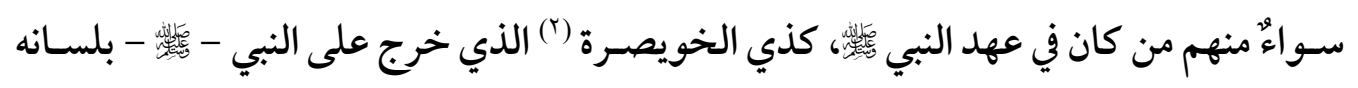
معترضًا عليه في توزيع الغنائم. ولهذا قال الإمام ابن الجوزي معلقـًا على اعتر اضــه هذا بـأن:" هـذا أول خـارجي خرج في الإسلام، وآفته أنه رضي بر أي نفسه، ولو وقف لعلم أنه لا رأي فوق رأي رسول الله، وأتباع هذا

(1) الملل والنحل: محمد بن عبد الكريم الثـهـرســاني، تحقيق: محمد ســيد كيلاني، دار المعرفة، بيروت،

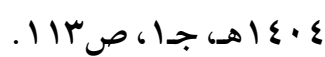

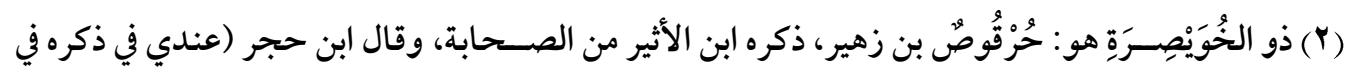

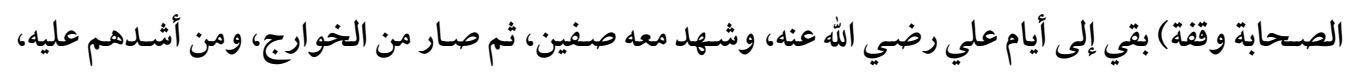
و كان مع الخوارج لما قاتلهم علي رضي الله عنه، فقتل في النهروان سنة سبع وثلاثين (انظر : أسد الغابة في معرفة وعند

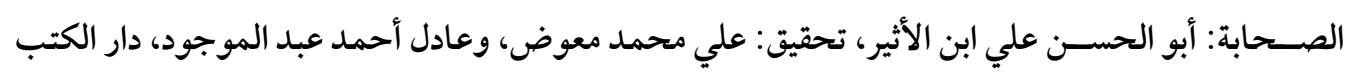

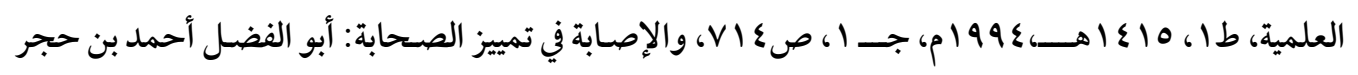

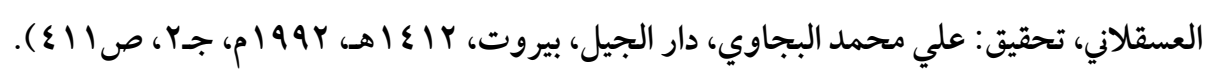




\section{الرجل هم الذين قاتلوا علي بن أبي طالب كرم الله وجهه "(')}

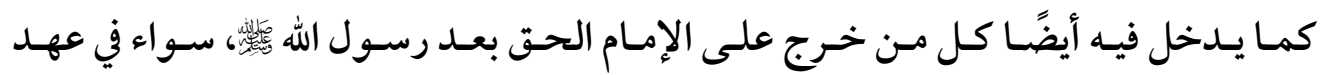

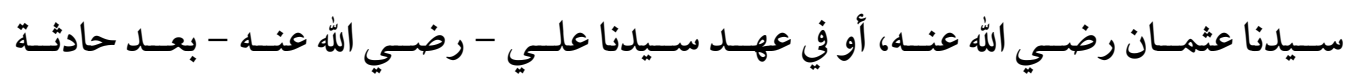
التحكـيم، ويثـمل كـذلك كـل مـن خــرج على إمـام مـن أئمسة المسـلمين اجتمعـت عليـهـ

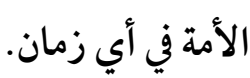

وقــد أشـار إلـى هــذا ابـن حجـر - رحمـه الله - فتــال:" أمـا الخـوارج فهـم جمـع خارجـة

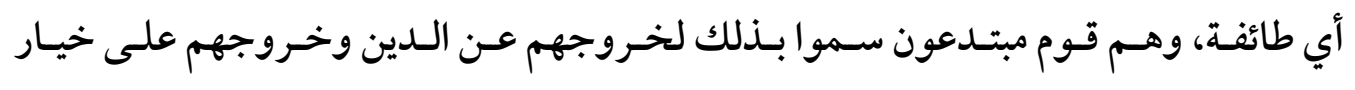

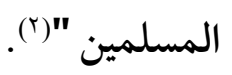

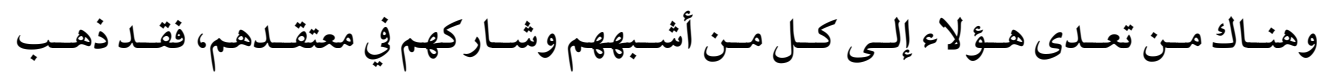
الإمـام ابـن حـزم - رحمـهـ الله - إلـى أن:" مـن وافـق الخــوارج مـن إنكـار الـتحكم وتكفيـر

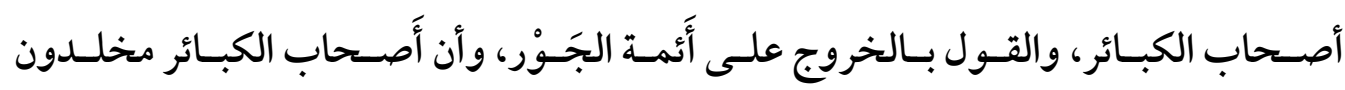
فِي النـار، وأن الإمامـة جـائزة في غيـر قريش فهـو خـارجي، وإن خـالفهم فيمـا عـدا ذلك ممـا اختلف فيه المسلمون فليس خارجيًا "(「).

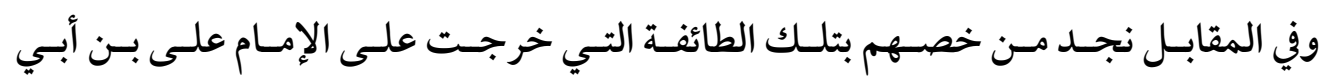
طالـب رضـي الله عنسه، وبـين أن خـروجهم عليسه هـــ العلـة في تسـميتهم بـالخوارج، حيـث (1) تلبيس إبليس: عبد الرحمن بن علي أبو الفرج بن الجوزي، تحقيق: الســـ الجميلي، دار الكتاب العربي،

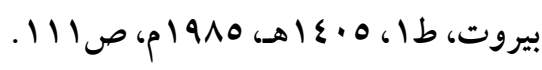

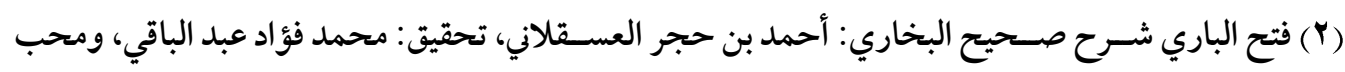

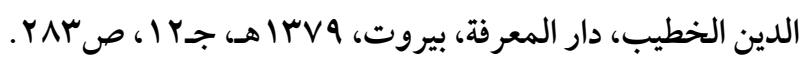

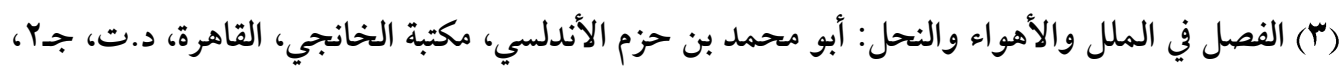

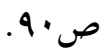


المجلد السابع والثلاثون إصدار ديسمبر 19.0.

قـال الإمـام أبــو الحسـن الأثـعري - رحمـهـ الله-:" والسـبب الــذي لـه ســموا اخـوارج خروجهم على علي بن أبي طالب" (').

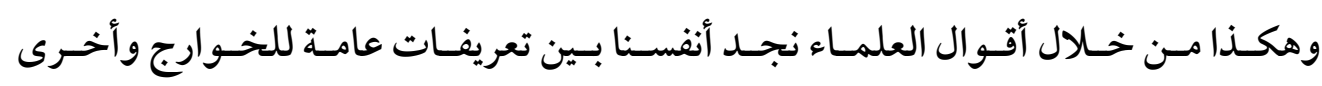

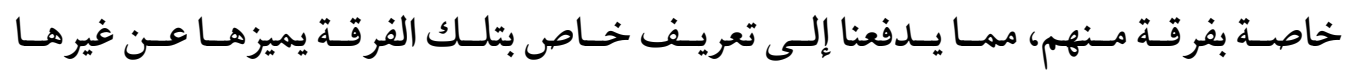

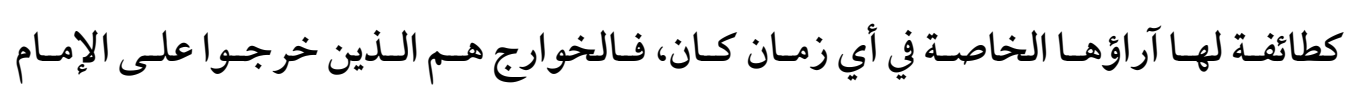
على - رضي الله عنه - بعـد قبوله التحكسيم في موقعسة صـفين، ومسن وافقهـم ورأى آرائهم من الناس إلى يوم الدين.

فهـذا يعـد هـو التعريـــ المناسـب للخهوارج، لكثـرة مـن صـار عليـه مـن علمـاء الفـرق في

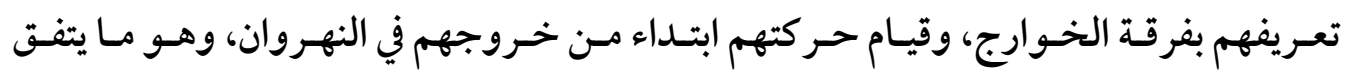

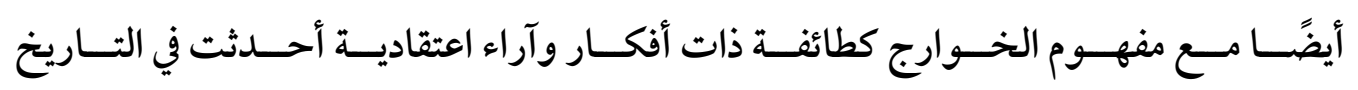

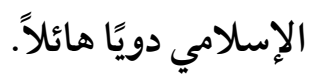

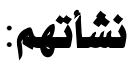

اختلف العلماء في تحديد بدء نشأة الخوارج على أقوال، أهمها ما يلى:

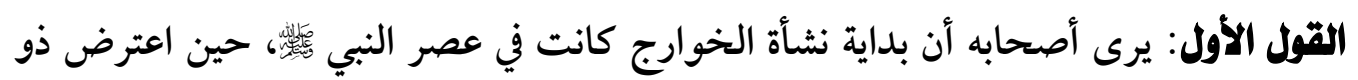

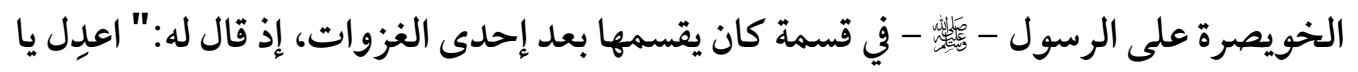

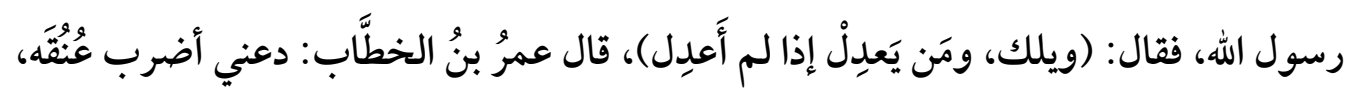

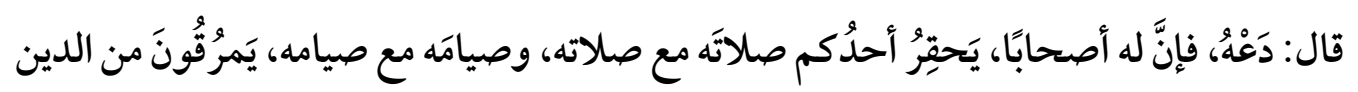

(1) مقالات الإسلاميين: أبو الحسن الأشعري، تحقيق: هلموت ريتر، دار فرانز شتايز، مدينة فيسبادن (ألمانيا)، ط 
وقد ذهـب إلى هذا القول ابن الجوزي، حيث علق على الحديث الســابق فقال:" فهذا أول خارجي خرج في الإسـلام .... وأتباع هذا الرجل هم الذين قاتلوا علي بن أبي طالب كرم الله

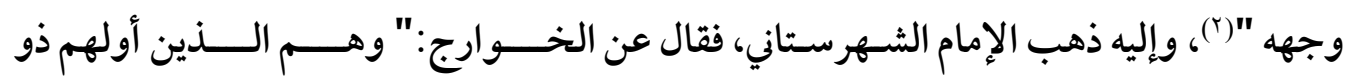
الخويصرة "(") كما ذهب إليه آخرون.

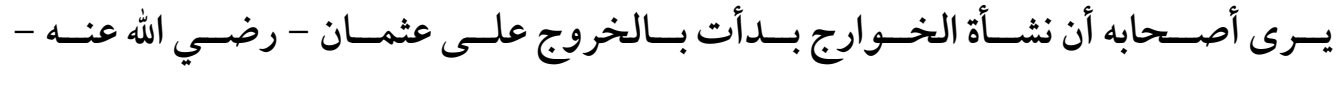

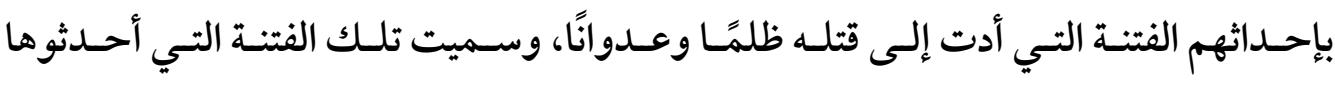
بالفتنـة الأولى، وإليـه ذهـب الإمـام ابـن كثيـر، فقــ أطلـق - أثنـاء تعرضـه لهـذه الفتنـة - على

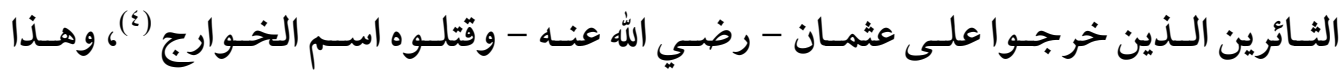

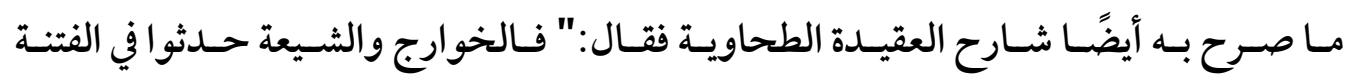
الأولى "(o)، وهي التي قتل فيها عثمان رضي الله عنه.

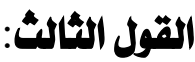

أن نثـأتهم بـــأت بانفصـالهم عـن جـــ الإمـام علـى رضـي الله عنـه، وخــروجهم عليـه في

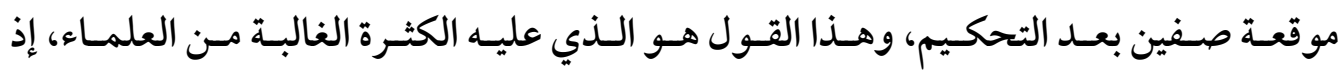

(1) أخرجه الإمام البخاري في صسحيحه، كتاب: اسـتتابة المرتدين والمعاندين وقتالهم، باب: مَنْ تَرَكَ قِتَالَ

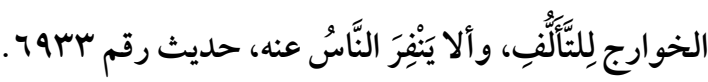

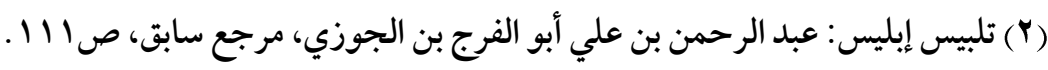

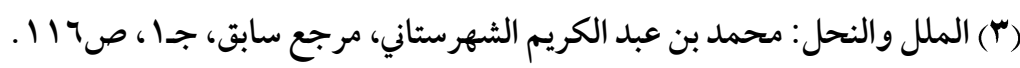
(ع) البداية والنهاية: أبو الفـداء إسـماعيل بن كثير، تحقيق: علي شـيري، دار إحياء التراث العربي، طا،

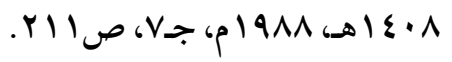

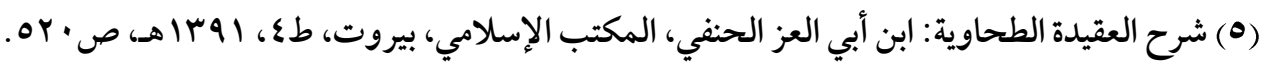




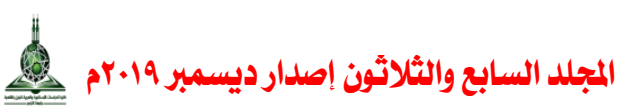

يعرفون الخوارج بأنهم هم الذين خرجوا على الإمام على بعد التحكيم.

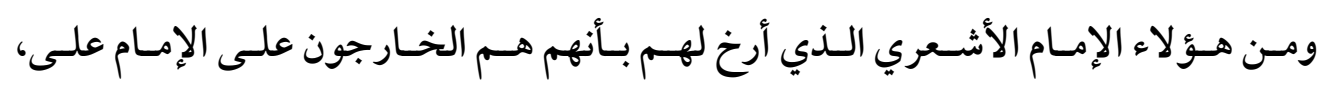

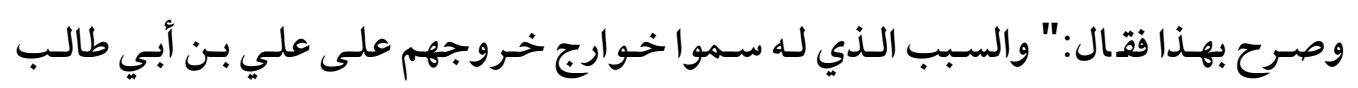

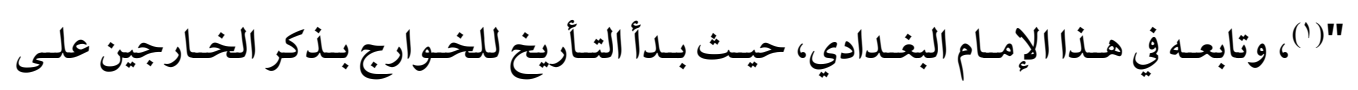
الإمام على رضي الله عنه (().

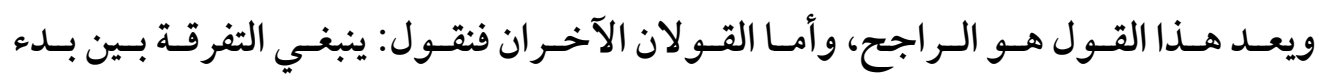

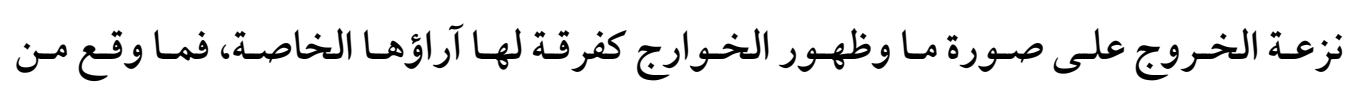

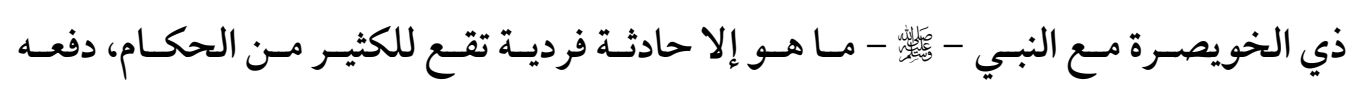

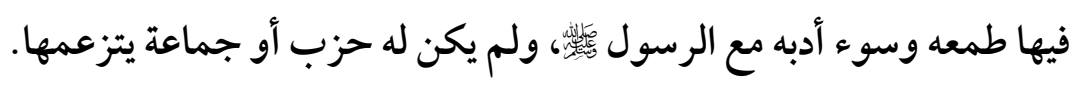

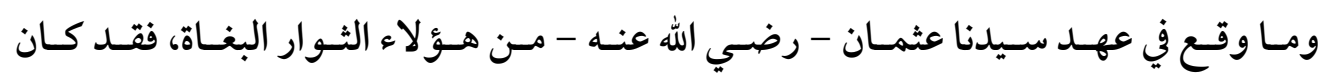

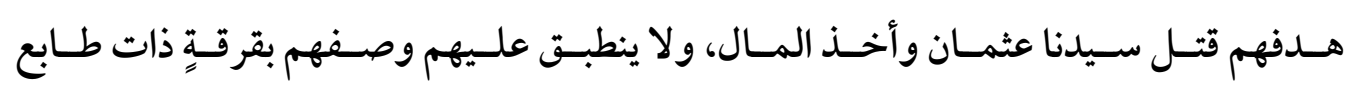

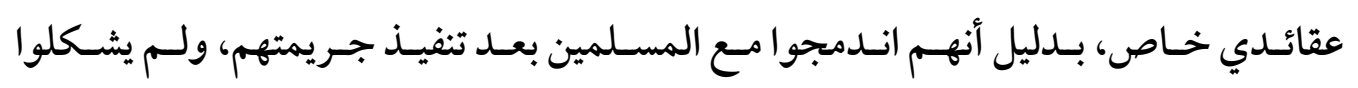
فرقة مستقلة (").

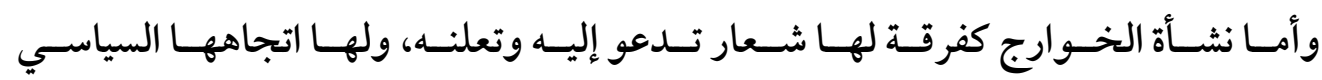

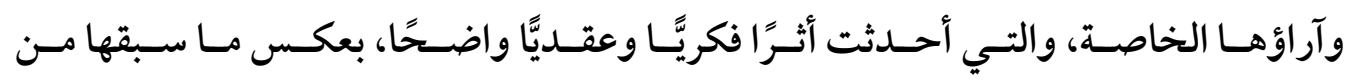

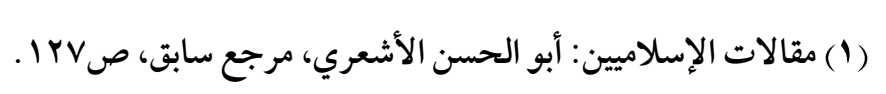

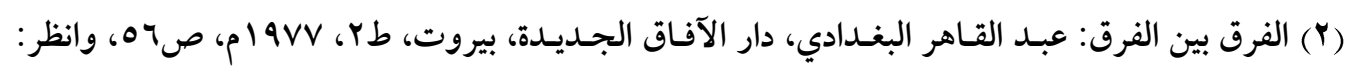

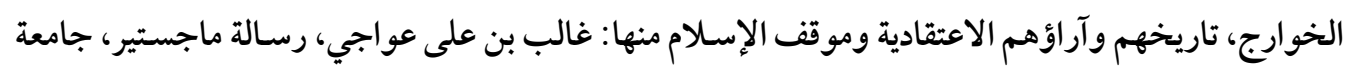

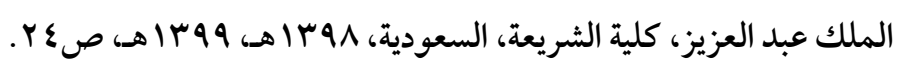

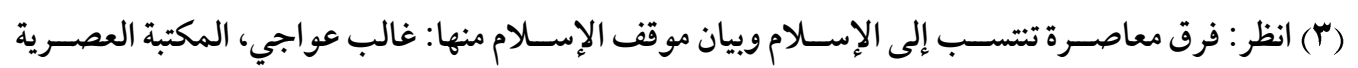

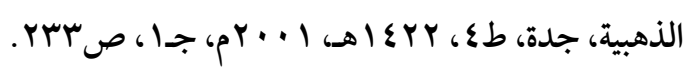


وقائع، فكان في عهد سيدنا على - رضي الله عنه - في موقعة صفين.

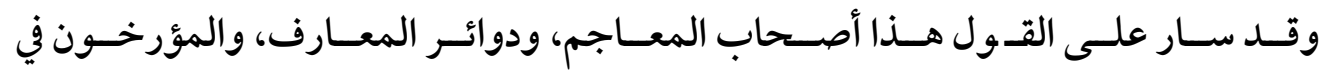

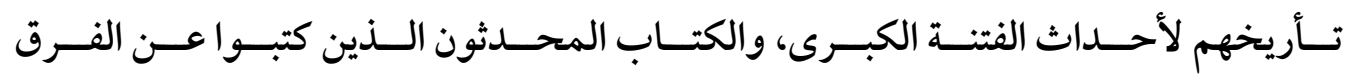
الإسلامية، كالأستاذ أحمد أمين والشيخ أبو زهرة وغيرهما.

يقول الأســاذ أحمد أمين:" واســم الخوارج جاء من أنهم خرجوا على علىّ وصــبه "(()، ويقول الشـيخ أبو زهرة:" اقترن ظهور هذه الفرقة (الخوارج) بظهور الثـيعة، فقد ظهر كلاهما كفرقة في عهد على رضي الله عنه، وقد كانوا من أنصاره "((؟).

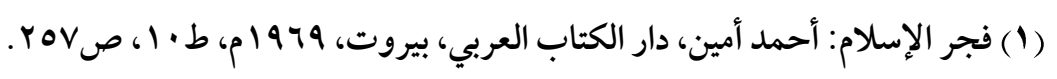

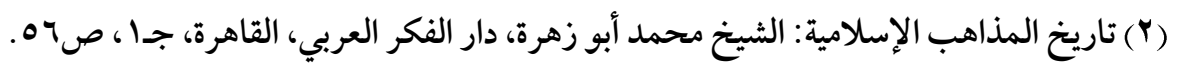




\section{الاطلب الثاذي \\ ألقاب الخوارج وفرقهم}

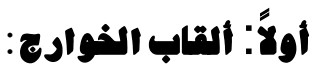

للخوارج ألقابُ ومُسـمَّيَاتُ كثيرة نسبة لعدة أمور، ومن هذه الأسـماء ما يرتضسونه ويفتخرون به، ومنها ما لا يرتضـونه، وسـأحاول هنا حصـر أهم ما وقفت عليه من هذه الأسـماء والألقاب، وبيان أصلها بذكر الشواهد على صحة إطلاق تلك الألقاب عليهم:

اــ الخوارج: وهو من أشهر أسمائهم التي تطلق عليهم، وسموا به نسبة لخروجهم على أئمة المسلمين وجماعتهم أو عن الدين، وقد ورد ذكر هذا الاسم في بعض الأحاديث، فعن يُسَيْرِ بنِ

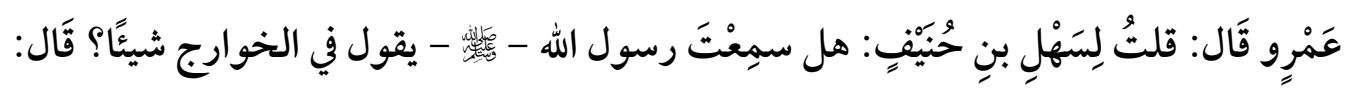

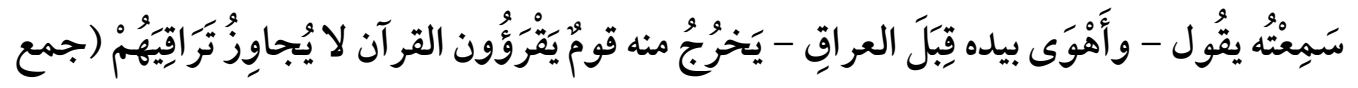

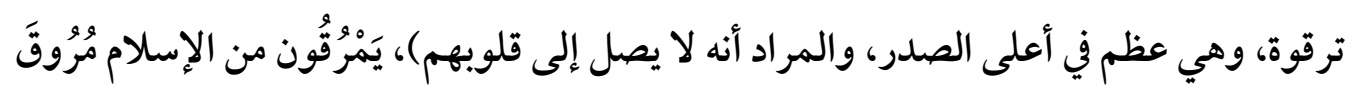

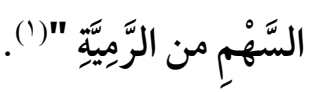

وهو اسـم يحتمل أن يكون مدحًا لهم أو ذمًا، فإذاذ كانت التسـمية مأخوذة من قوله تعالى (وَمَنْ

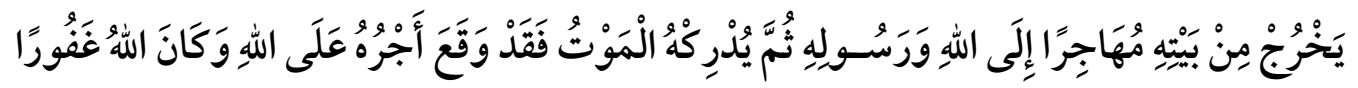
رَحِيمًا) (النسـاء: آية ، . (1)، فهي مدح يقبلونها بل ويفتخرون بها، إذ يزعمون أن خروجهم إنما هو في سبيل الله، فهو خروج على أئمة الجور والفست، وهو موقف يقبله الإسـلام، ويقولون: إن الخروج عن الدين مروق يسمى أصحابه المارقة، أما الخروج إلى الدين فإن أصحابه هم الذين يسمون الخوارج والخارجة، لأن خروجهم هو للجهاد في سبيل الله (「).

(1) أخرجه الإمام البخاري في صسحيحه، كتاب: اسـتتابة المرتدين والمعاندين وقتالهم، باب: من ترك قتال

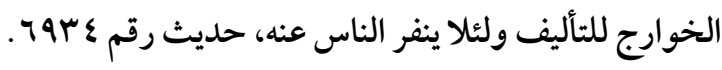

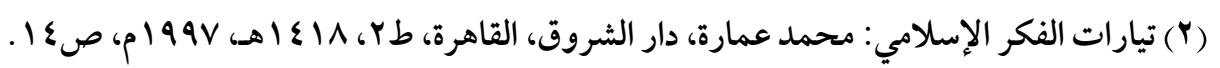


وإذا كانت التسـمية بمعنى الخروج على الأئمة أو عن الدين أو عن الإمام على رضسي الله عنه، فهي ذم وير فضسونها، ويرون أن هذا من تشـنيع خصومهم عليهم، وأنهم هم الذين سـموهم بهذا

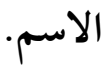

بـ المُحَكتمة: وهو من أوائل أسمائهم التي أطلقت عليهم، وسبب تلقيبهم بذلك لإنكارهم التحكيم، وقولهم "لا حكم إلا له"، وقد صح عن الإمام علي - رضي الله عنه - أنه لما سمع مقالتهم "لا حكم عِلا لله" قال :" كلمة حق أريد بها باطل "(')، وقد صارت هذه الكلمة (لا حكم إلالله) شعارًا لهم عندما يريدون الخروج عن طاعة الو لاة أو الهجوم على خصومهم في أي معر كة

"َـ الحَرُورِيدة: وسبب تسميتهم بذلك أنهم في أول أمرهم اعتزلوا جيش الإمام علي بن أبي طالب - رضي الله عنه - لما رجع من صفين، ونزلوا بمكان يقال له حَرَوراء، وهو مكان قريب من الكوفة، فسموا بذلك نسبة للموضع الذي نزلوا به، وإلى هذا أشار الإمام الأشعري فقال:" والذي سموا له حرورية نزولهم بحروراء في أول أمرهم "((). وإطلاق هذا اللقب على الخوارج كان مشــهورا عند الصـحابة - رضــي الله عنهم، حتى إن المُبرَّد ذكر أن عليًّا - رضسي الله عنه - هو الذي ســماهم بالحرورية لاجتماعهم بحروراء (؛)،

(1) أخرجه الإمام مسلم في صحيحه، كتاب: الزكاة، باب: التحريض على قتل الخوارج، حديث رقم 74 ـ ا.

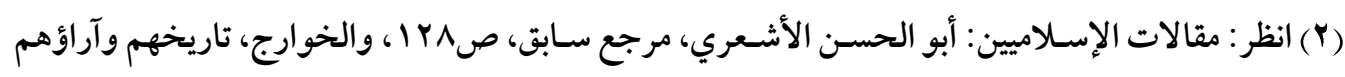

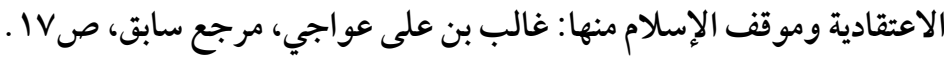

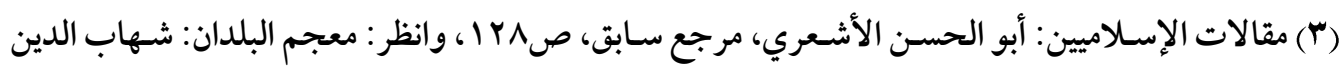

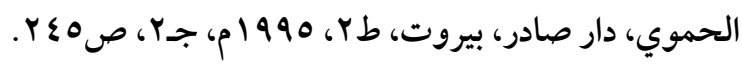

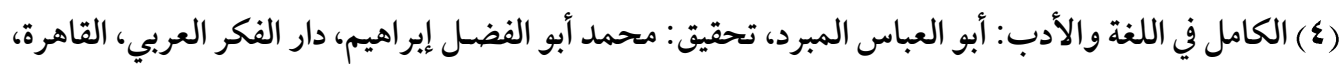

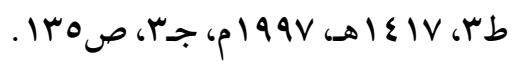




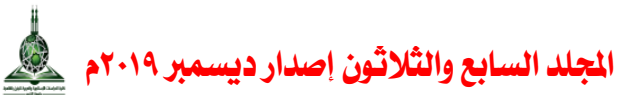

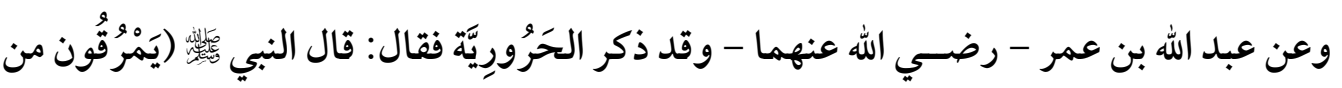

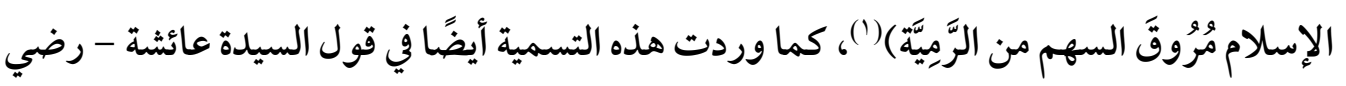
الله عنها - لما سألتها تلك المر أة عن الحائض تقضى الصوم ولا لا تقضى الصلاة، قالت: أحرورية

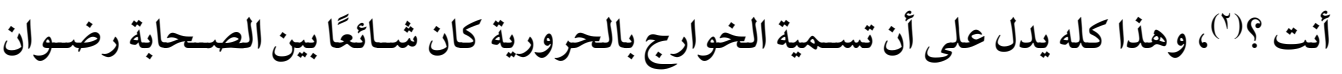
اللّه - تعالى - عليهم جميعًا.

ك المارقة: وقد سموا بذلك لأنهم يمرقون من الدين لغلوهم فيه، كما جاء في الحديث السابق

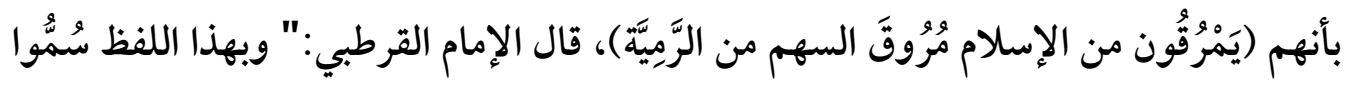

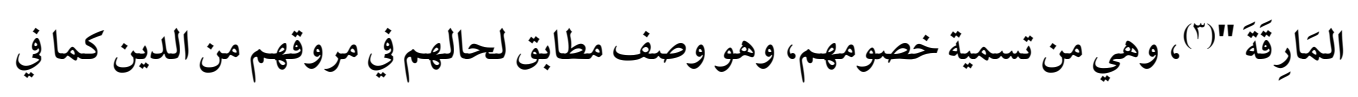
الحديث، ومروقهم وخروجهم على المسلمين.

مـ الشراة: وهو من الأسماء التي يحبها الخوارج، ويتسمون بها، وسبب تسميهم بذلك: لزعمهم

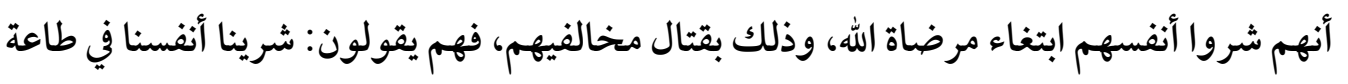

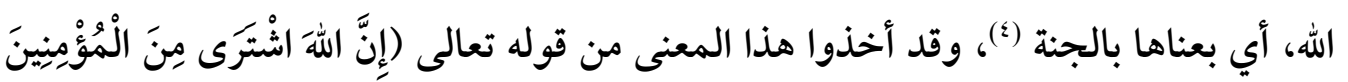

(1) أخرجه الإمام البخاري في صسحيحه، كتاب: اسـتابة المرتدين والمعاندين وقتالهم، باب: قتل الخوارج

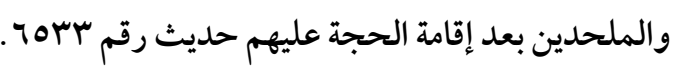

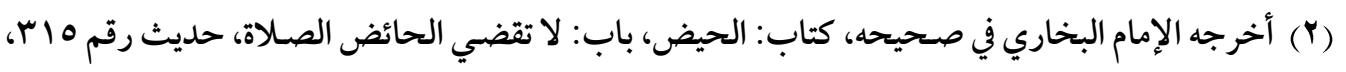

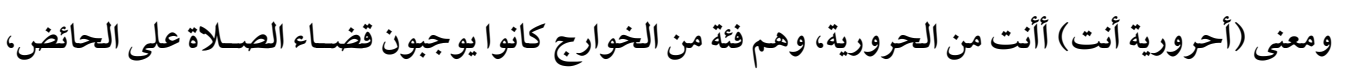

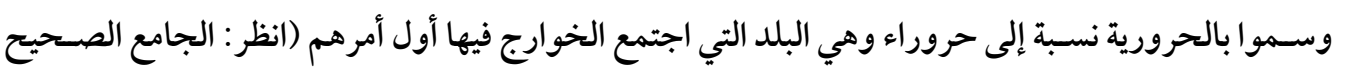

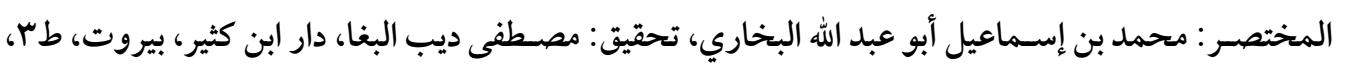

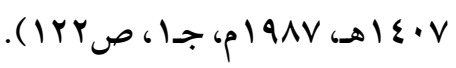

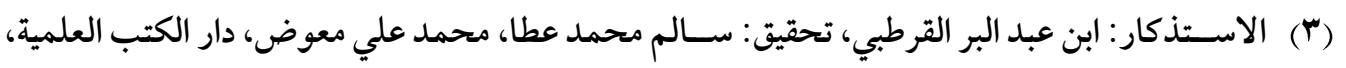

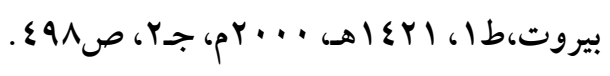

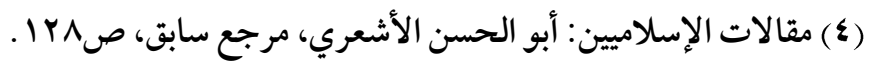




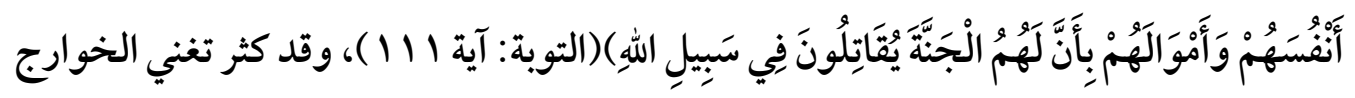

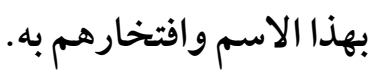

Iـ الأكمُرة: وقد سُّمُّوا بهذا لأنهم يُكفِّرون بالمعاصي والكبائر، ويُكفّرون مَنْ خالفهم من المسلمين، ويحكمون عليهم بالخلود في النار، قال فيهم ابن عبد البر :" وهم قوم استحَلُّو ابما

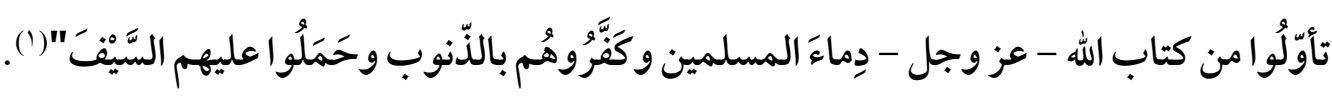
تلك هي أهم وأشـهر أسـماء الخوارج وألقابهم، وهم يحبون هذه الأسـماء كلها، ولا ينكرون منها شيئًا إلا تسميتهم بالمارقة، فإنهم لا يرضون به، لأنهم يعتبرون أنفسهم على الهدى والحق، وأمـا من عـداهم فبإنهم - من وجهة نظرهم - ظـالمون وأهـل جَوْرِ وكفر، وقـد أشـــار الإمـام الأشعري إلى هذا فقال:" وهم يرضون بهذه الألقاب كلها إلا بالمارقة، فإنهم ينكرون أن يكونوا مارقة من الدين كما يمرق السهم من الرمية "(؟).

\section{شاذيًَ: فوق الخوادج:}

عُرف عن الخوارج أنهم كانوا يختلفون ويفترقون لأتفه الأسباب، ولهذا نجدهم يكفر بعضهم

بعضًا عند أقل نازلة تنزل بهم من دقائق الفتيا وصغارها (").

ومن أجـل هـذا تشـعبـت فرقهم وتعـدت، وقـد تبـاينـت أقوال مؤرخي الفرق في تعـداد فرق

الخوارج، فالأشعري جعـل أصسول الخـوارج أربع فرق، لكنه وصل بتعدادهم إلى حوالي ست

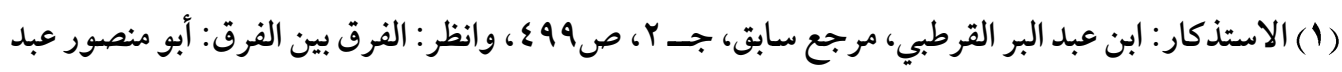

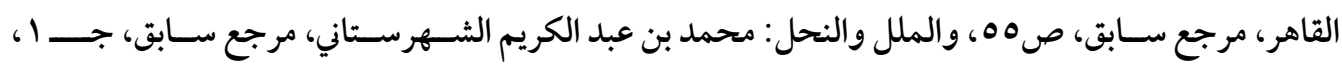

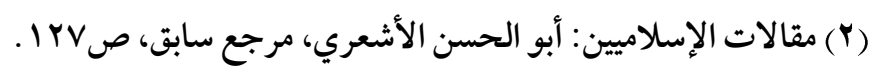

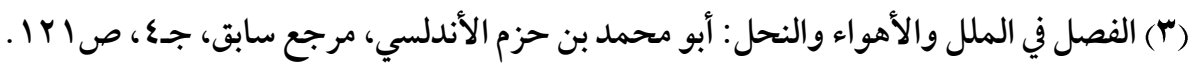




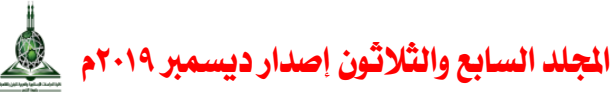

وثلاثين فرقة (')، وجعل الشهرستاني كبار فرق الخوارج ستة لكنها تصل بالانقسامات داخلها

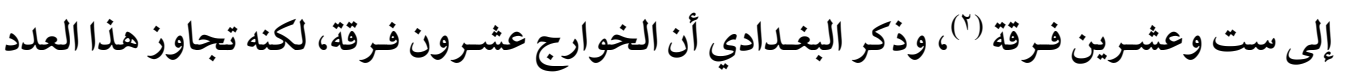

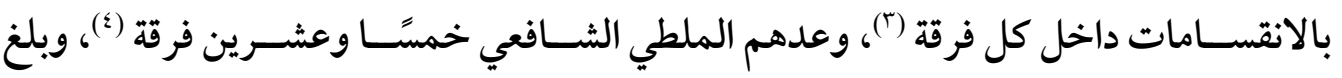

تعدادهم عند الرازي إحدى وعشرين فرقة (o)، وجعلهم الإمام الاسفراييني عشرين فرقة (ج).

ولا يسـع المقام هنا لذكرهـا جميعًا، كمـا أن القدر المتفق عليه بين الجميع أن كبار فرق

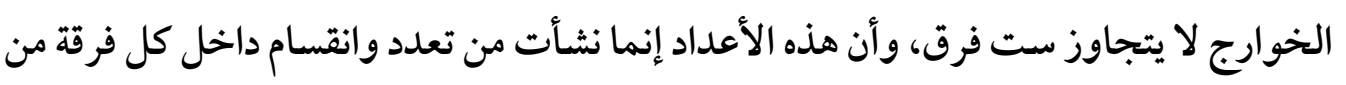

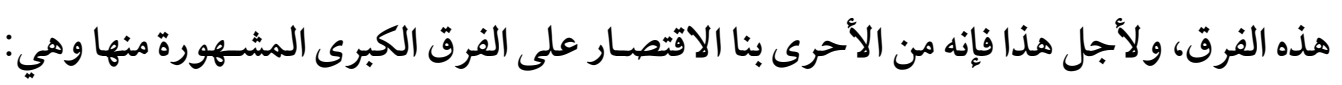
الأزارقة، والنجدات، والصفرية، والإباضية، حتى لا يطول بنا الحديث.

\section{أولاً: الأزارقة:}

هم أتباع نافع بن الأزرق الحنفي المكنى بأبي راشد، وهو أول من أحدث الخلاف بينهم، وهم

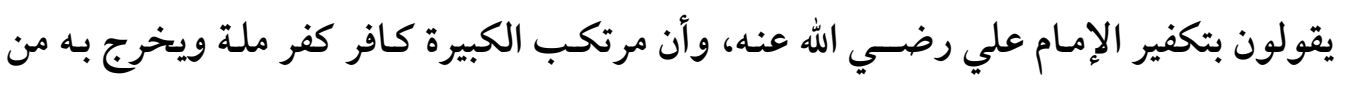

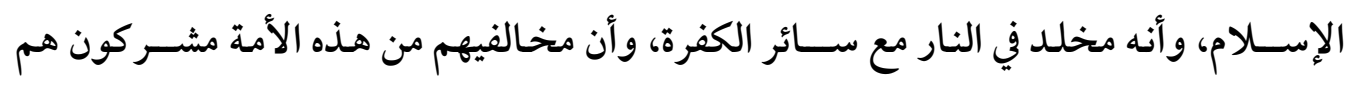

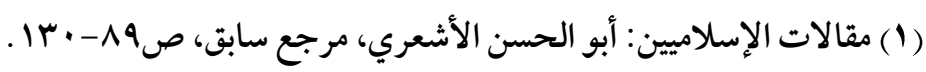

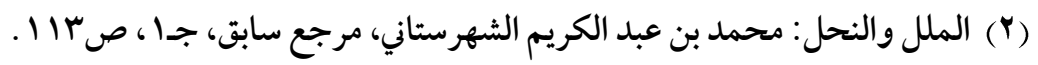

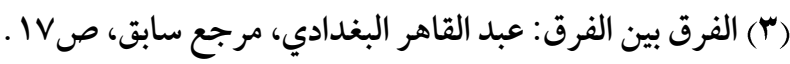

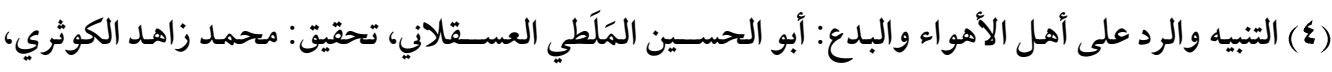

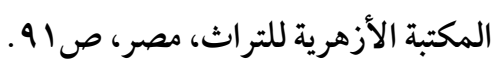

(•) اعتقادات فرق المسلمين والمشركين: أبو عبد الله الرازي، تحقيق: علي سامي النشار، دار الكتب العلمية،

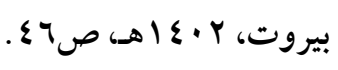

(آ) التبصير في الدين وتمييز الفرقة الناجية عن الفرق الهالكين: أبو المظفر الأسفراييني، تحقيق: كمال يوسف

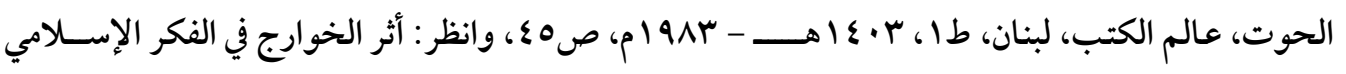

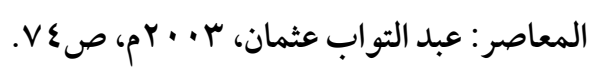


وأطفالهم، واستحلوا قتلهم وقتالهم، وأن دار مخالفيهم دار حرب يستباح فيها ما يستباح في دار الحرب، وأسقطو احد الرجم عن الزاني المحصن إذ ليس في القرآن - على حد قولهم - ذكر له، وأوجبوا على الحائض الصلاة والصيام في حيضها، وقالوا باستعر اض كل من لقوه من غير أهل عَسْكَرَهْمْ ويقتلونه إذا قال أنا مسلم، ويحر مون قتل من انتمى إلى اليهود أو إلى النصارى أو إلى

وبالإضــافة إلى ذلك نادى الأزارقة ببعض الآراء الدالة على جهلهم بالثــــع وعدم فقههم في الدين، فأجاب نافع إلى ذلك بعض الخوارج، وفارقه بعضـهـم، فأحدث بذلك الخلاف بين الخوارج، ثم قتل ســنة 70 هـــ، عندما اشـتدت المعر كة بينه وبين جيش أهل البصــة في ناحية الأهواز، فولى الخوارج أمرهم إلى الثــاعر المعروف قطري بن الفجاءة الذي انشـقـت عليه

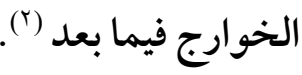

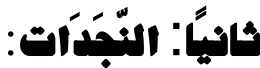

هم أتباع نجدة بن عامر الحنفي، والذي كان أحد أتباع نافع بن الأزرق، فلما أخبر بما أحدثه نافع من آراء عن استباحة قتل أطفال مخالفيه وغيرها من الآراء الفاسدة، أعلن انفصاله عن نافع وتبرئه منه، وبايعه بالإمامة هؤلاء الذين انشـقوا عن نافع في آرائه، فصـار أميرًا على طائفة من الخوارج عرفوا بالنجـات، وأصــح لنجدة وأتباعه نفوذ في دائرة واسـعـة شــملت البحرين وشواطئ الخليج، وامثد إلى عمان وبعض من أجزاء اليمن.

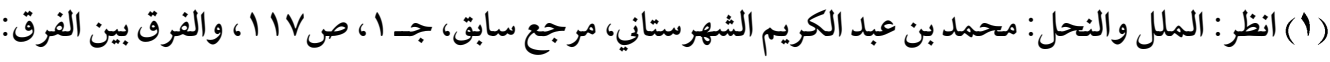

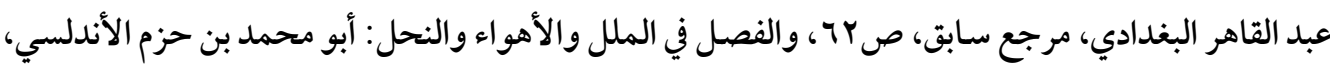

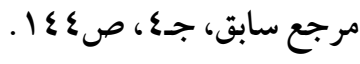
(Y) الكامل في التاريخ: أبو الحســن بن الأثير، تحقيق: عمر عبد السـلام تدمري، دار الكتاب العربي، بيروت، b 
وذهبت النجدات إلى أن الدين أمران: أحدهما: معرفة الله تعالى ومعرفة رسـله عليهم الصـلاة والسـلام، وتحريم دماء المسـلمين، وتحريم غصسب أموال المسـلمين، والإقرار بما جاء به من عند الله تعالى جملة، فهذا واجب معرفته على الجميع، والجهل به لا يعذر فيه، والثاني: ما سوى ذلك، فالناس معذورون فيه إلى أن تقوم عليهم الحجة في الحلال والحرام.

وقد اختلفت النجدات مع زعيمهم نجدة، ونقموا عليه عدة أمور، منها تعطيله حد الخمر، وعدم عدله في تقسـيم الفيء، وتفريقه الأموال بين الأغنياء من أتباعه وحرمانه ذوي الحاجة منهم، ومكاتبته عبد الملك بن مروان، ووصل الخلاف بينهم إلى قتل نجدة، وانقسموا من بعده إلى ثلاث فرق هي: النجدية والعطوية والفديكية (').

\section{هالثةاً: المنُْرية:} هناك خلاف كبير حول نسبة الصفرية، وهل سموا بذلك نسبة للصفرة التي تعلو وجوههم من أثر العبادة، أم سـموا بذلك نسـبة إلى رجل بعينه، كما نسـبت الأزارقة والنجدات والإباضـية؟ وأرجح هذه الأقوال: أن هذه الفرقة تنسـب إلى عبد الله بن صــفار التميمي الذي كان مع ابن الأزرق في بداية عهده ثم انفصـل عنه وقوع الخلاف بين قادة الخوارج، وقيل: إن نسـبتهم إلى زياد بن الأصفر. وهؤلاء لا يختلفون كثيرًا في تعاليمهم عن الأزارقة، غير أنهم لا يرون قتل أطفال أصسحاب الر أي المخالف لهم ونسـائهم، ومرتكب الذنب عندهم يسمى باسـم الذنب الذي ارتكبه، زان، سـارق، ولا يسـمى كافراً أو فاسـقًا وهذا بالنسـبة إلى الذنوب التي فيها حدّ مقرر، وأما الذنوب التي ليس فيها حدّ مقرر لذلك كترك الصـاة أو الصـوم، فمرتكبها يعد كافرًا، والشــرك عندهم شـر كان: شـرك هو طاعة الشيطان، وشـرك هو عبادة الأوثان، والكفر كفران: كفر بإنكار النعمة،

(1) انظر : الفرق بين الفرق: عبد القاهر البغدادي، مرجع سابق، صجT ، والملل والنحل: محمد بن عبد الكريم

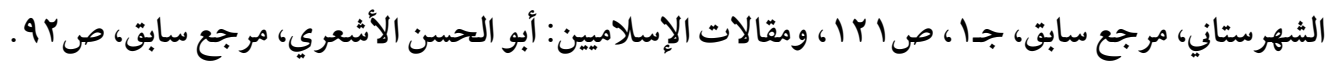


وكفر بإنكار الربوبية، والبراءة براءتان: براءة من أهل الحدود وهي سنة، وبر اءة من أهل الجحود

وهي فريضة (')

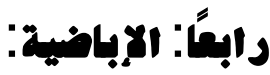

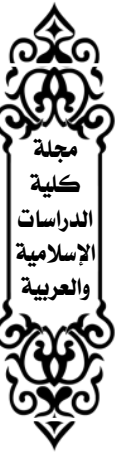

هم أتباع عبد الله بن إباض التميمي، أو المنسـوبون إلى قرية من قرى اليمامة اسـمها (إباض)، على خلاف في ســبـ التسـمية، وكانت بداية الإباضــية في البصــرة، ثم تمركزت بعد ذلك في منطقتين: الأولى: عُمان على السـاحل الثـرقي الجنوبي من جزيرة العرب، والثانية: المغرب العربي في أجزاء من أرض ليبيا وتونس والجزائر، ولا يزال إلى اليوم تمركز الإباضـية في عمان، ولا يزال لهم وجود في اليمن وليبيا وتونس والجزائر (「). والإباضية هي أقل فرق الخوارج غلوًا، وأكثرها اعتدالاً، وأقربها إلى فكر أهل السنة، فعندهم أن كفر مرتكب الذنوب الكبائر هو كفر نعمة، أي جحود النعمة، وليس كفر شرك بالله، والإيمان عندهم هو جميع ما افترضـه الله على خلقه، ولم يقولوا - مثل الأزارقة - أن أطفال الكفار كفار مخلدون في النار.

كما أن حكمهم على المخالفين لهم من المسلمين يختلف عن بقية فرق الخوارج، فبينما ترى أغلب فرق الخوارج أن ما عداهم من المسـلمين كفـار مشـــكون، يجب قتالهم ولا يجوز مناكحتهم ولا إرثهم ولا أكل ذبائحهم، ودارهم دار حرب، نجد أن الإباضـية فإنها وإن رأت جواز قتال المسلمين أحيانًا، إلا أنها تقول: بأنهم كفار نعمة، ويجرون عليهم أحكام الموحدين،

(1) الفرق بين الفرق: عبد القاهر البغدادي، مرجع سـابق، ص •V، والملل والنحل: محمد بن عبد الكريم

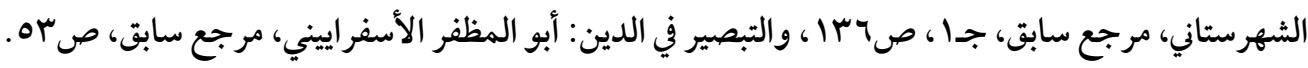

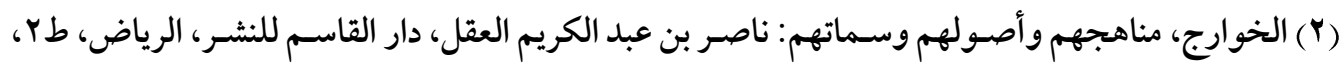
.0. 0.01 | IV 
من حيث النكاح والإرث والسبي والغنائم، وجواز معايشتهم والإقامة بينهم ('). ولا شــك أن هذا الحكم السـابق والذي خالفت فيه الإباضـية ســائر فرق الخوارج، يُعد من الفوارق الرئيسـية، بل هو الميزة التي أضـفت على الإباضـية ســمة الاعتدال تجاه المخالفين، والتي جعلت الإباضية تعايش بقية المسلمين وتسالمهم حتى اليوم. هذا وقد انقســـت الإباضـية إلى فرق: فالفرقة الأولى منهم يقال لهم الحفصـية كان إمامهم حفص بن أبي المقدام، والفرقة الثانية منهم يسمون اليزيدية كان إمامهم يزيد بن أنيسة، والفرقة الثالثة منهم يســمون بالحارثية أصسحاب حارث بن يزيد الإباضسي، ولهذه الفرق من الأقوال والاعتقادات ما يخالف ويتصادم مع العقيدة والثريعة الإسلامية (؟).

ومن ينظر إلى فرق الخوارج التي تحدثنا عنها والتي لم نتحدث عنها يجد أنها قد انقرضـت، وغدت أقو الها جزءًا من تراثنا الإسـلامي، ولم يبق من الخوارج سـوى الإباضسية، الذين لا تزال لهم بقايا حتى الآن في أجزاء من الوطن العربي وشـرقي أفريقيا، وهؤلاء ينكرون صـلتهم تمامًا بمذهب الخوارج، إذ قد تطور مذهبهم، وطوعت الحياة وأحداثها أفكارهم، حتى اقتربوا من مذهب أهل السنة في الكثير من الأصول والأقوال والمسائل، لكن يبقى الغلو والتشدد الخارجي حيًا موجودًا في أفكارهم، تبرزه الأزمات والمحن التي تمر بها أمتنا الإسلامية.

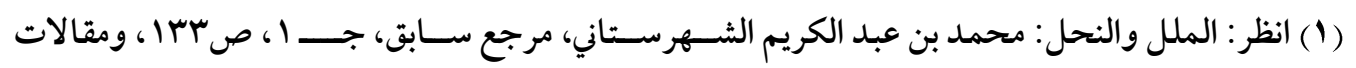

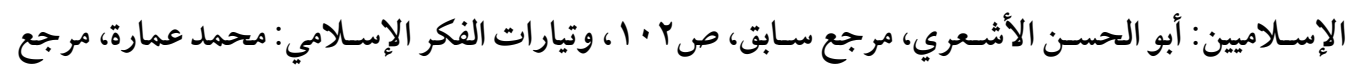

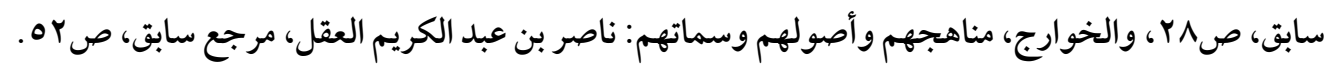

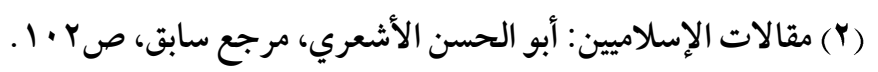




\section{الإطلب الثالث}

\section{المبادئ العامة للخوارج}

إن للخوارج علامـات ودلالات تـدل عليهم، ولهم اجتهادات وآراء وأقوال كثيرة متشـعبة، ولكن هناك عددًا من الأصــول والقواسـم المشـتر كة التي اجتمع و أجمع عليها عامة الخوارج،

\section{أولاً: الخروج على الإمام الجائر:}

يرى الخوارج أن الإمام هو المثل الأعلى، ولهذا يجب أن يكون متصـفًا بذلك قولاً وفعلاً، فإن خطأه ليس كخطأ غيره من الناس، فالإمام عندهم يسـتمر في وظيفته ما قام بالعدل وأقام الثـرع وابتعد عن الخطأ، فإن حاد وأخطأ وجب محاسـبته والخروج عليه، فإما أن يعدل وإما أن يعتزل أو يقتل، فإنه حق مشروع لهم حينئذ.

يقول البغدادي فيما يرويه عن الكعبي:" إن من الأمور التي أجمعت عليها الخوارج إجماعهم على وجوب الخروج على الإمام الجائر "(')، وأشــار كذلك الثــهرســاني في بيانه لموقف الخوارج من الإمام فقال:" وإن غير السيرة وعدل عن الحق وجب عزله أو قتله "(؟).

والأعجب من هذا أن الخوارج يحاسـبون الإمام ويخر جون عليه لأتفه الأسـباب، ويرون أن إثـهار السـيف في وجهه ووجوه أتباعه من إقامة الدين وإظهاره عاليًا، لأن الظلمة لا ولاية لهم، ولا تجب طاعتهم، وإن اختلفوا فيما بينهم في جوازه أو وجوبه، يقول الإمام الأثـعري:" وأما السـيف فإن الخوارج تقول به وتراه إلا أن الإباضـية لا ترى اعتر اض الناس بالسـيف، ولكنهم يرون إزالة أئمة الجور ومنعهم من أن يكونوا أنمة بأي شـيء قدروا عليه بـالسـيف أو بغير

$$
\text { (1) الفرق بين الفرق: عبد القاهر البغدادي، مرجع سابق، صهـ. }
$$

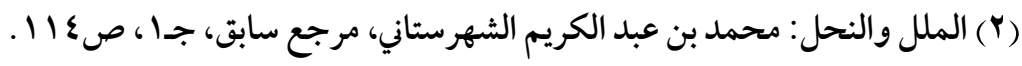


وهكذا يعيش الإمام عندهم بين فكي الأسـد، يحاسب على كل ما يصدر منه محاسبة دقيقة لا تأخذهم فيه لومة لائم فلا طاعة لجائر، لأنهم ينكرون الجور أشـــد الإنكار، ولا يعترفون بإمام يعتقدون أنه قد جار في حكمه، فيخرجون عليه إذا ارتكب ذنبًا ولم يتب منه، أو أظهر جور في حكمه، أو كان فيه تقصير عن إقامة الحدود، فإن الخروج عليه حينئذ يكون واجبًا وقتاله حق.

\section{ثانيًا: الإمامة الكبرى:}

الإمامة منصـب خطير لابد من إقامته، إذ لا يمكن أن ينعم الناس بالحياة ويســود الأمن بينهم وتنتظم الأمور إلا بحاكم يكون المرجع في تطبيق الشرع وحماية الأمة وإقامة العدل بين أفرادها، وقد أقر على هذا جميع العقلاء، فماذا كان موقف الخوارج إزاء هذه المسألة ؟ والجواب أن عامة الخوارج يرون ضـرورة الإمامة الكبرى والانضسواء تحت راية الإمام والقتال معه ما دام على الطريق الأمثل الذي ارتأوه له، ويقررون صـلاح المسـلم وصـلاحيته الذي تتوافر فيه شـروط الإمامة لتولى هذا المنصـب، بصـرف النظر عن نسـبه وجنسـه ولونه، ومن ثم فهم يختلفون عن كثير من فرق الإسـلام وتيار اته السياسية التي اشترطت النسب القرشي أو العربي

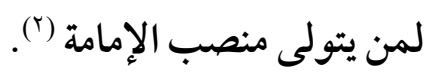
وهم يقفون مع الر أي القائل بأن الاختيار والبيعة هما الطريق لتولي وتنصيب الإمام، فمن صار أهلاً للإمامة جاز توليته دون نظر إلى نسبه، يقول الإمام الأشسعري:" والخوارج يرون أن الإمامة في قريش وغيرهم إذا كان القائم بها مستحقًّ لذلك، ولا يرون إمامة الجائر"("َ)، ويرى الإمام ابن

$$
\begin{aligned}
& \text { (1) مقالات الإسلامين: أبو الحسن الأشعري، مرجع سابق، صه } 1 \text {. . }
\end{aligned}
$$

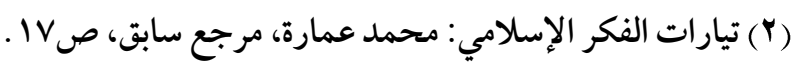

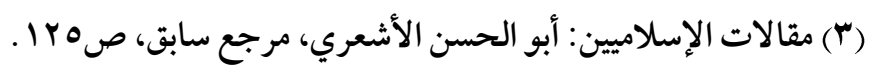


حزم أن من وافق الخوارج في أشياء ومنها: أن الإمامة جائزة في غير قريش فهو خارجي (') ومع اتفاق عامة الخوارج على ضــرورة ووجوب تنصـيب الإمام والدخول تحت رايته ما دام على الطريق الصواب، إلا أن النجدات قد خالفوا هذا، ورأوا أنه قد يستغنى عن الإمام إذا عرف كل واحد الحق الذي عليه للآخر وأداه إليه، ولم يتعد أحد على أحد بظلم أو أذى.

يقول الإمام الأشسعري:" وحُكى عن النجدات أنهم يقولون: إنهم لا يحتاجون إلى إمام، وإنما

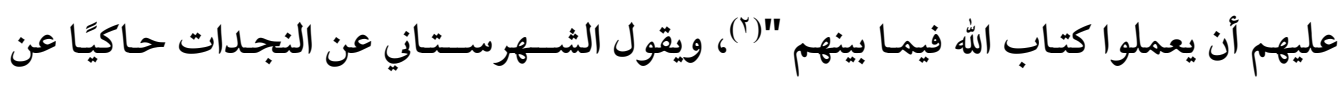
الكعبي:" وأجمعت النجدات على أنه لا حاجة للناس إلى إمام قط، وإنما عليهم أن يتناصـفوا فيما بينهم، فإن هم رأوا أن ذلك لا يتم إلا بإمام يحمله عليه فأقاموه جاز" (†). فالأمر عندهم راجع إلى المصـلحة وما تقتضسيه لا إلى أنه واجب وجويًا شـرعيًا يتحتم عليهم إنفاذه، ولا شك أن ما ذهب إليه النجدات في هذا المقام يعتبر خروجًا على إجماع عامة الخوارج الذين يرون ضــرورة نصــب الإمام، كما أن القول بالاســغنـاء عن الإمام قول في غاية البعد والسـقوط، يقول الإمام النووي:" وأجمعوا - أي المسـلمين - على أنه يجب على المسـلمين نصب خليفة، ووجوبه بالشرع لا بالعقل "(8)، وإلي هذا أشار القاضي عبد الجبار فقال:" اتفقت الأمة على اختلافها في أعيان الأئمة أنه لابد من إمام يقوم بهذه الأحكام وينفذها "(o.).

(1) الفصل في الملل والأهواء والنحل: أبو محمد بن حزم الأندلسي، مرجع سابق، جـr، ص •9.

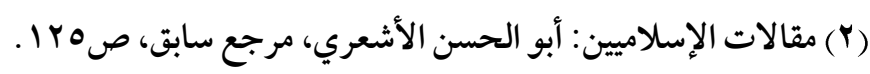

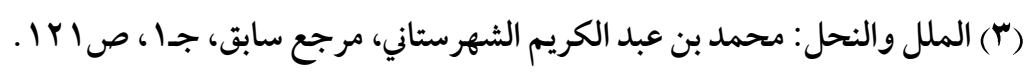

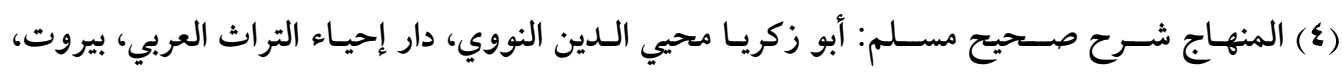
(r. (•) شـرح الأصسول الخمسـة: القاضسي عبد الجبار، تحقيق: عبد الكريم عثمان، مكتبة وهبة، القاهرة، ط؟،

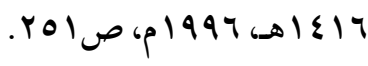




\section{المجلد السابع والثلاثثن إصدار ديسمبر 19.0.}

قال الإمام ابن حزم بعد أن ذكر أن القول بوجوب الإمامة قد أجمعت عليه جميع أهل السـنة

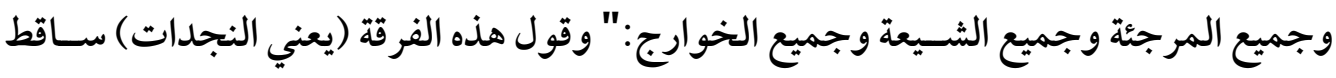
يكفي من الرد عليه وإبطاله إجماع كل من ذكرنا على بطلانه "( ().

وهو رأي واضـح لا حاجة إلى الإطالة فيه، ولكن النجدات لم تلتفت إلى الناحية الثـرعية بل

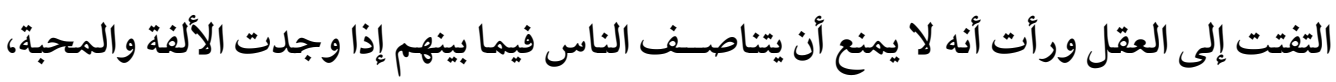

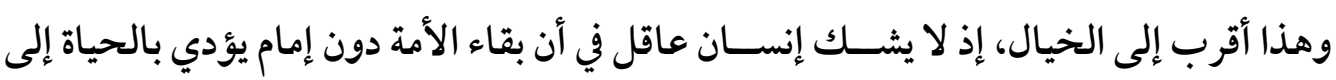
الفوضى والظلم وتشتيت الكلمة وإثارة الحروب المدمرة.

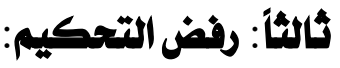

إن رفض التحكيم هو حجر الأساس لفرقة الخوارج، فاتخذوه شعارًا لهم أيام حياة الامام علي

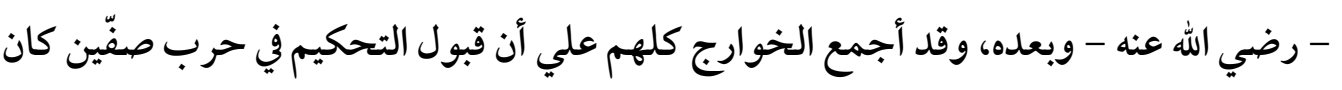

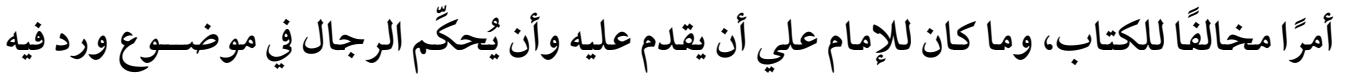
حكم إلهي في مصدرين رئيسيين أعني الكتاب والسنّة. رغم أنهم هم الذين أجبروا الإمام عليّ على قبوله في بداية الأمر، طلبًا لحقن دماء المسـلمين،

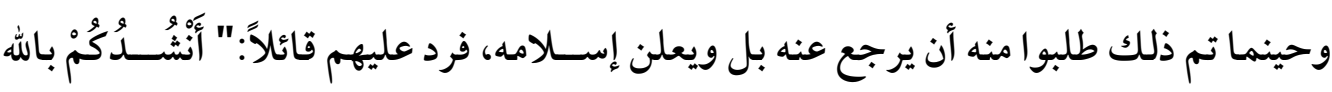
أتعلمون أنهم حيث رفعوا المصاحف فقلتم: نجيبهم إلى كتاب الله، قلت لكم: إني أعلم بالقوم منكم، إنهم ليسو أبصحاب دين؟ وذكر ما كان قاله لهم "((). فرفض التحكيم إذا مبدأ عام عند الخوارج، وتأصسيلا على هذا المبدأ حكموا بتكفير الإمام

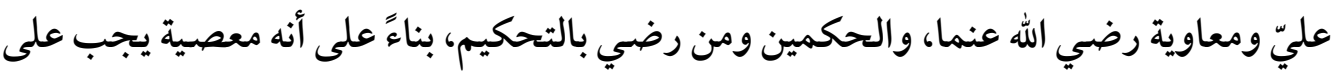

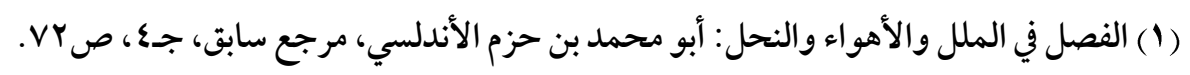

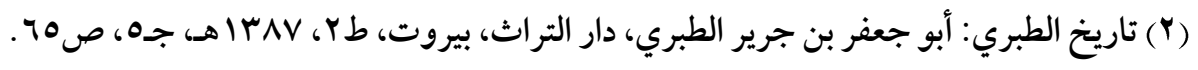


الجميع أن يتوب منها، وقـد أشار إلى هذا الإمام البغدادي فقال:" إن الذى يجمع الخوارج على افتراق مذاهبها إكفار على وعثمان والحكمين وأصسحاب الجمل وكل من رضسى بتحكيم الحكمَيْنِ"(1)

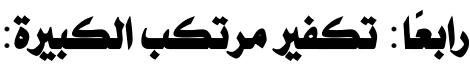

أنكر الخوارج أن تكون في المعاصسي صسيرة وكبيرة، وقالوا: إن الكل كبيرة، ويرون أن من

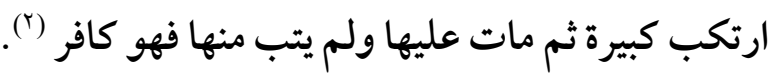

وقد أجمعـت على ذلك سـائر فرقهم إلا النجـدات منهم، قال الإمـام الأثـعري في بيـان

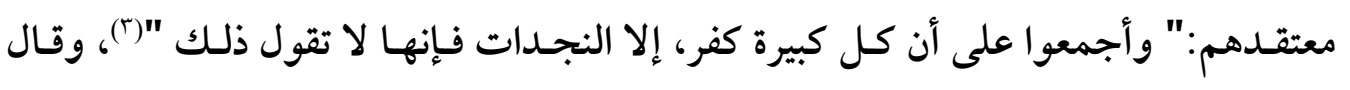

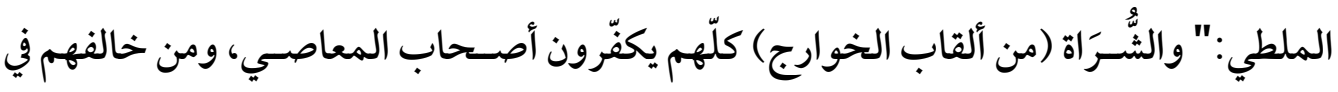

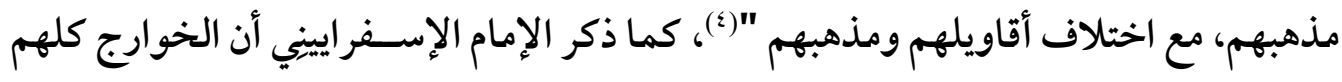

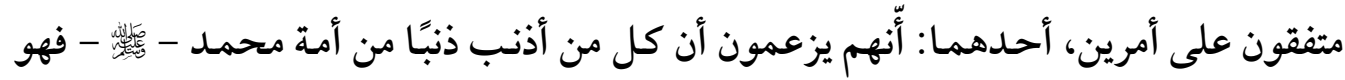

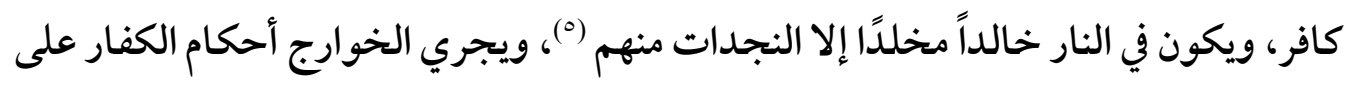
أهل المعاصسي في الدنيا، فيستبيحون دماء وأموال أهل القبلة من أهل الكبائر، لاعتقادهم بكفرهم.

وأما النجدات فقالوا: لاندري لعل الله يعذب المؤمنين بذنوبهم، فإن فعل فإنما يعذبهم في غير

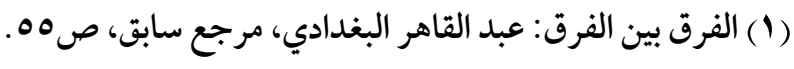

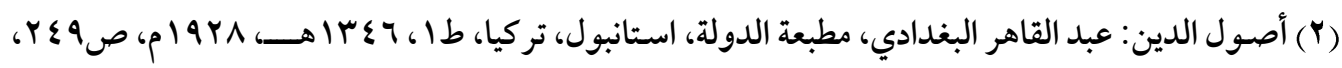

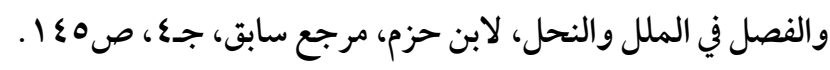

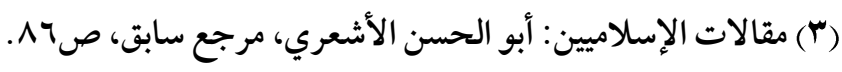

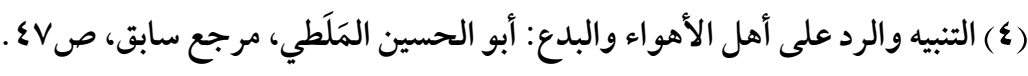

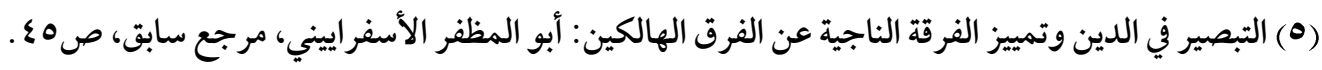




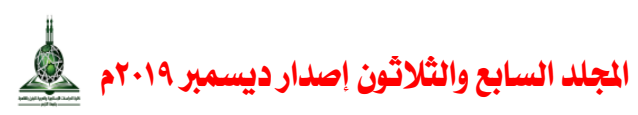

النار بقدر ذنوبهم، ولا يخلدهم في العذاب، ثم يدخلهم الجنة، وزعموا أن من نظر نظرة صسغيرة أو كذب كذبة صغيرة، ثم أصر عليها فهو مشرك، وأن من زنى وسرق وشرب الخمر غير مصر

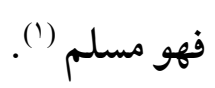

ولما حكم الخوارج على أهل الكبائر في الدنيا بالكفر وخروجهم من الدين بالكلية، زعموا أن حكمهم في الآخرة هو دخول النار، وأنهم سيخلدون فيها خلودًا أبديًا، وأن الله لا يغفر لهم شيئًا من ذنوبهم إن لم يتوبوا منها في الحياة الدّنيا، قال الإمام الأشـعري:" وأجمعوا (أي الخوارج) على أن الله - سبحانه - يعذّب أصحاب الكبائر عذابًا دائمًا إلا النجدات "(؟).

(1) مقالات الإسلاميين: أبو الحسن الأشعري، مرجع سابق، ص1 91.

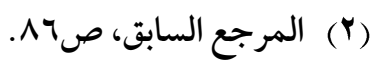




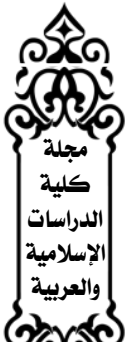

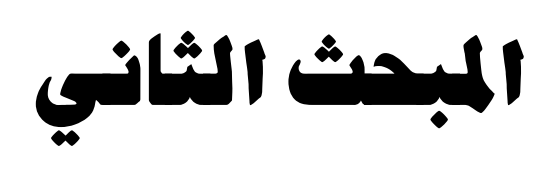

$$
\text { أفكار الخوارج بين الماضي والحاضر }
$$

$\checkmark$

$$
\begin{aligned}
& \text { وفيه أربعة مطالب: } \\
& \text { المطلب الأول : ظاهرة التكفير } \\
& \text { المطلب الثاني: ظاهرة الغلو } \\
& \text { المطلب الثالث: ظاهرة الشدة والغلظة }
\end{aligned}
$$$$
\text { المطلب الرابع: ظاهرة الجدل وميلهم إليه وقوتهم فيه }
$$ 


\section{المبلب الأول}

\section{ظاهــرة التكفير}

تفاقمت هذه الظاهرة واشتد خطرها مع جماعة الخوارج في عهد الإمام على - رضي الله عنهو كثير من الصحابة، واستمرت تتناسل جيلاً بعد جيل عبر تاريخنا الإسـلامي لتحصـد الأرواح وتسـفك الدماء وتهلك الحرث والنسـل، حتى أكابر علمـاء أمتنا الإســلامية أمثال الرازي والفارابي والبيروني وابن سـينا وابن رشـد والعسـقلاني والسـهروردى والنووي والكواكبي وابن خلدون وغيرهم، لم ينجوا من سـلاح التبديع والتفسـيق والتكفير والثــنق والطرد ومصــادرة أعمالهم، وقد أصبحت ظاهرة التكفير هي فتنة الأمة الإسلامية اليوم.

إن ما يجرى اليوم على ألسـنة الكثير من الشـباب وغيرهم من تكفير وتفسـيق لعباد الله بلا دليل ولا تَثَبَّت، يعد من أخطر الأمور وأشدها فتكـا وضر رًا، حيث لا تكاد تخفى على أحد نتائج هذا التكفير وعو اقبه إذا ما فثـي في مجتمع من المجتمعات، فإنك ترى ذلك المجتمع وهو في حالة من القلق المستمر والتقطع والتفسـخ، لا يكاد يهنأ بر احسة بال أو طيب عيش. والتكفير بغير علم مجازفة خطيرة وانتهاك لحرمة دين الله وشــريعته، وخوض فيما نهى الله -

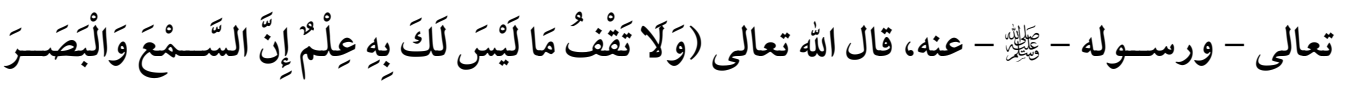

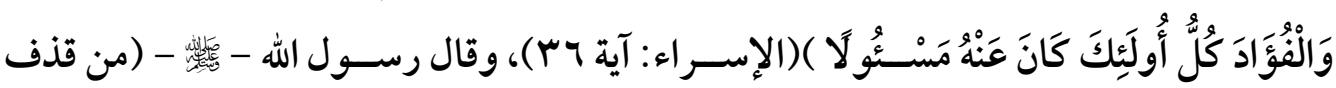

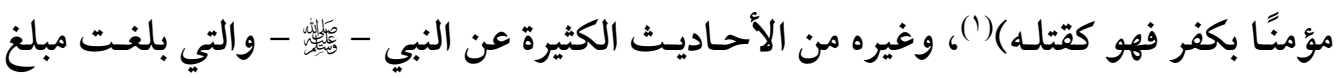
الاستفاضة في تحريم ذلك وتجريم فاعله.

وهذا لا يعنى أننا نسـد باب التكفير على الإطلاق ونفتح الباب للمفسـدين يقولون ويفعلون ما يريدون وما يشــاءون، كلا، وإنما نقصــــــهذا القول التكفير الذي لم يســتوفِ كآفة الثــروط (1) أخرجه الإمام البخاري في صحيحه كتاب: الأدب، باب ما ينهى من السباب واللعن، حديث رقم . . Vه. 
والبحث في ظاهرة التكفير من حيث خطورته ونتائجه وضو ابطه ومو انعه لا يحسـنه من بضاعته مثلى، ولكنها الرغبة الشديدة منى في مشار كة المصلحين ولو بجهد المقل، آملاً في الأجر من الله ونفعًا للمسـلمين، فأعرض هذا المبحث مسـاهمةً متو اضسعةً فيما تواجهه أمتنا من مشكلات في هذا الميدان، كي يكون معينًا للشـباب لتكوين رؤيا سـليمة، وعقيدة واضـحة في هذه القضـية الخطيرة. تعريف التكفير:

لغلة: التكفير مشـتق من مادة كفر التي تدل في اللغة على معنى السـتر والتغطية، قال ابن فارس:"

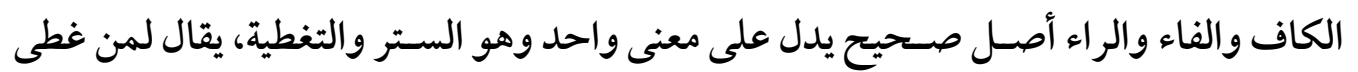
درعَه بثوب: قد كفر درعَه، ويقال للزارع كافر، لأنه يغطي الحب بتراب الأرض، كما في قوله

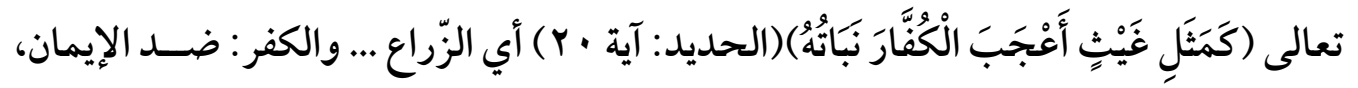
سـمي بهذا لأنه تغطية الحق)(')، وقال الر اغب:" والتَّكْفِيرُ: ســر الشـيء وتغطيته حتى يصـير

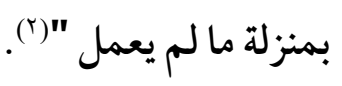

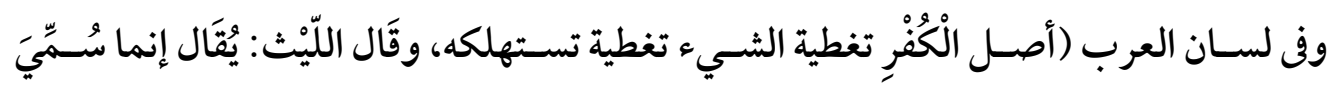

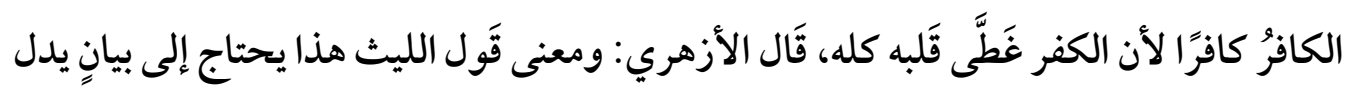
عليه وإيضــاحه أن الكفر في اللغة التغطية، والكافر ذو كفر أي ذو تغطية لقلبه بكفره، وسُـمِّيَت

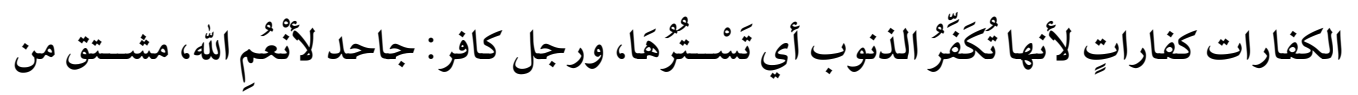

(1) معجم مقـاييس اللغـة: أحمـد بن فـارس بن القزويني، تحقيق: عبـد السـلام محمــد هـارون، دار الفكر،

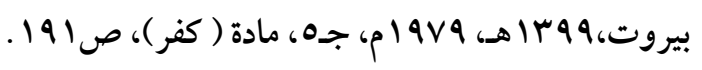

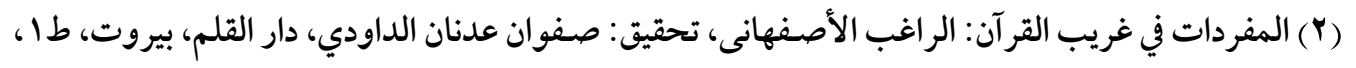
r| 
إذاً فالكفر في اللغة أصـل معناه: السـتر والتغطية وجحد الحق الظاهر أو النعمة، والتكفير : هو وصف الشخص بالكفر.

واصطلامًا: أحيانًا ترد كلمة الكفر في النصوص مر ادًا بها الكفر المخرج عن الملة، وأحيانًا أخرى ير اد بها الكفر غير المخرج عن الملة، ذلك أن للكفر شعبًا كما أن للإيمان شعبًا، وكل شعبة من شعب الإيمان تسمى إيمانًا، مصداقًَا لقوله تعالى (وَمَا كَانَ اللهُ لِيُِِيعَ ِِيمَانَكُمْم) (البقرة: آية r ع ا ) )، وهذه الشعب منها ما يزول الإيمان بزو الها كشعبة الشهادة، ومنها ما لا يزول بزوالها كترك إماطة الأذى عن الطريق، وكذلك الكفر ذو شعب كثيرة متفاوتة، منها ما توجب الكفر، ومنها ما

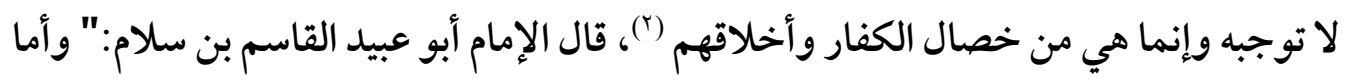
الآثار المرويات بذكر الكفر والشرك ووجوبهما بالمعاصي، فإن معناها عندنا ليست تُبْت على

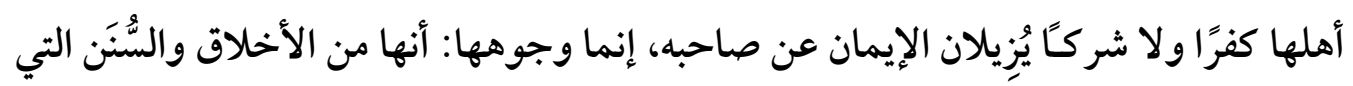
عليها الكفار والمشر كون "(r). لكن المتتبع لأقوال الخوارج من خلال كتـب العقـائـد والفرق والتـاريخ يجــ أنهم يكفرون بالذنوب أيًا كانت، وهذا هو الذي ميزهم عن غيرهم من أهل البدع مع خروجهم بالسـيف، فالخوارج تعد أول فرقة خرجت تكفر المسلمين بالذنوب. وقد صار لفظ التكفير اصطلاحًا معاصرًا مذمومًا، فلا يحمل إلا على تكفير المسلم دون وجه حق، أي وهو غير مسـتحق التكفير، وقد بحثت عن تعريف جامع مانع لهذا الاصــلاح فلم

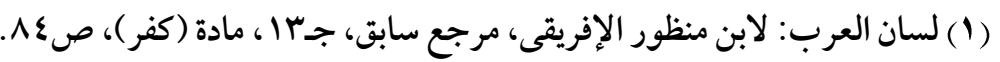

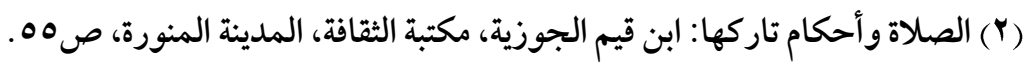

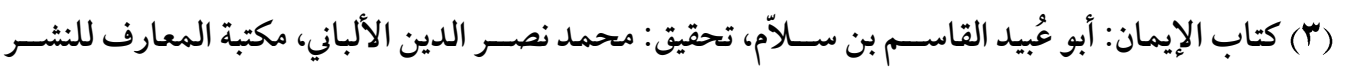

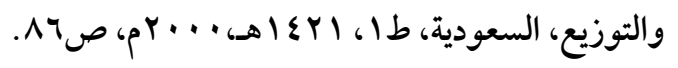


أجده، وبعد البحث والنظر رأيت أن أعرفه بما يلي: هو تنزيل أحكام الكفر على المسـلم فردًا أو جماعة أو حاكمًا بلا محاكمة شـرعية وبلا استيفاء الشـروط ولا الموانع التي يجب مراعتها في التكفير الثرعي المعتبر، أو هو الحكم على المسلم الذي ثبت إسلامه بالكفر دون أن تتوافر في حقه شروط التكفير الشرعية.

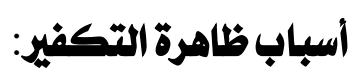

إن أسباب نشأة ظاهرة التكفير وانتشارها في القديم والحديث ترجع إلى مجموعة من الأسباب المتثـــابكة، عملـت جنبًا إلى جنـب في نشــر هـذه الظـاهرة وتـأمين البيئة الملائمـة لنموهـا واسـتمر ارها، وهذه الأسـباب تختلف من بلد إلى آخر، ومن جماعة إلى أخرى، ومن وقت إلى لى

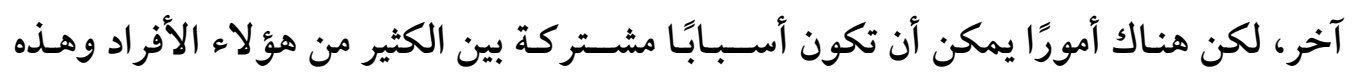
الجماعات في كثير من الأزمان والأوطان، فمن هذه الأسباب:

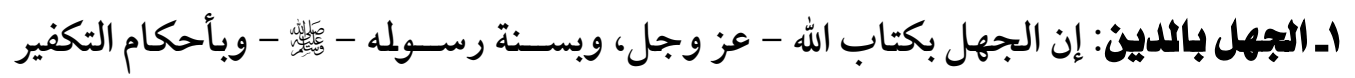
وقواعده، وكلام السـلف في ذلك، هو من أعظم الأسـبـاب الحاملة لأهل التكفير على تكفير

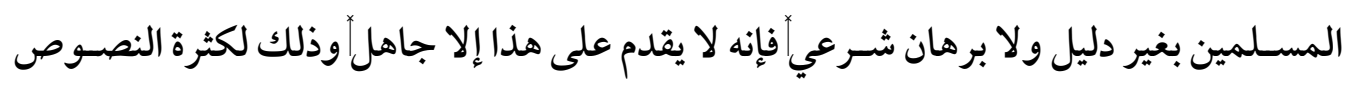

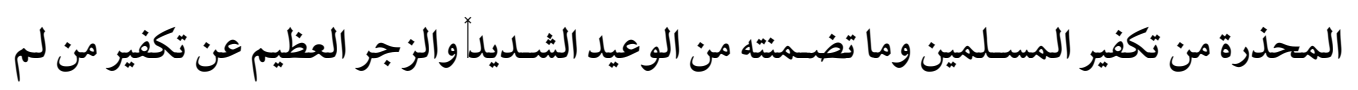
يكن مستحقًا للتكفيرً بحيث لا تخفى هذه النصوص إلا على جاهل مغرق في الجهل أولهذا كان العلماء يحتاطون أعظم الاحتياط في الحكم على المخالفين للشرع بكفر حتى يتبين لهم بالدليل أن قوله أو فعله كفر.

ولعل الجهل بأحكام الشريعة من أهم صفات الخوارج الذين كانو ا أول من تولى وزر التكفير في هذه الأمة، حين كفروا أصسحاب النبي - صلاته مع صلاتهم، وصيامه مع صيامهم، يقرؤون القرآن، لا يجاوز تراقيهم، يمرقون من الدين 
يقول الإمام القرطبي منددًا بضــلالة الخوارج وقلة فهمهم وجهلهم:" وكفى بذلك أن مُقَدَّمهم ردّ على رسول الله - بَّل - أمره، ونسبه إلى الجور .... ويكفيك من جهلهم وغلوهم في بدعتهم

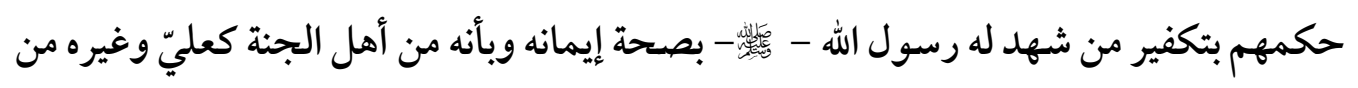
الصحابة "(())، وهذا الجهل والغلو ينطبق على أضرابهم الذين يأتون في آخر الزمان.

זـ اتباع الهوى: إن اتباع الهوى سببُ للضلال، ورفض الحق، وإتيان الباطل، وهو من أدهى الأسباب والحيل التي تقود إلى إنتاج وإفراز ظاهرة التكفير، فإنه يسيطر على صاحبه ويملك زمام عقله وقلبه ولبه، فلا يرى إلا برؤيته ولا ينفذ إلا ما يمليه عليه هواه، فيقوم بإنزال حكم التكفير على الآخرين لا لشيء إلا لاتباع هواه الضال المضل الذي جعل نفسه عبدًا له لا يطيع سواه، فهو الذي يأمره وهو الذي ينهاه. ويجب أن نعلم يقينًا أن الهوى ما خالط شـيئًا إلا أفسـده، فإذا خالط العلم أخر جه من الاتباع إلى الابتداع والضــلالة، وصـار صـاحبه من أهل الأهواء، وإن وقع في الزهد أخرجه إلى الرياء ومخالفة السـنة، وإن وقع في الحكم أخرجه إلى الظلم والصـد عن سـبيل الله، وإن وقع في العبادة أخرجها عن أن تكون طاعة وقربة، في أي مجال، في أي اتجاه، في أي منحى، إذا دخل الهوى أفسـده، وفي الحقيقة إن اتباع الإنســان لهو اه دليل على نقص عقله وضـعف إرادته وإيمانه وقلة

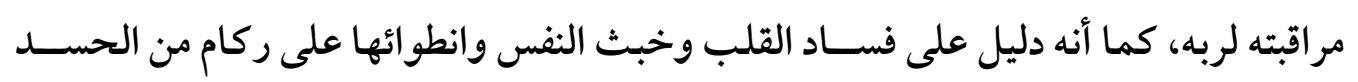
والبغي.

(1) أخرجه الإمــام البخاري في صسحيحه، كتـــاب: أحاديث الأنبياء، باب: باب علامات النبوة في الإسـلام،

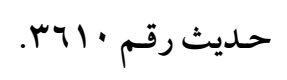

(r) المفهم لما أشكل من كتاب تلخيص مسلم: الإمام القرطبي، تحقيق: يوسف علي بدوي وآخرون، دار ابن

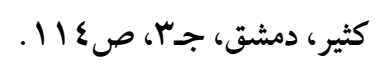


ومن ثم فقد تضــافرت النصــوص الثــرعية في ذم الأهو اء المضــلة والتحذير من اتباعها، قال

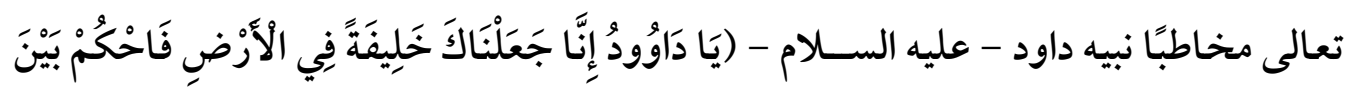

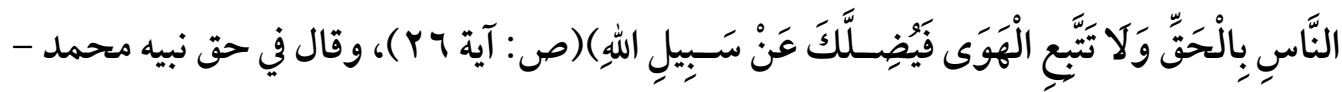

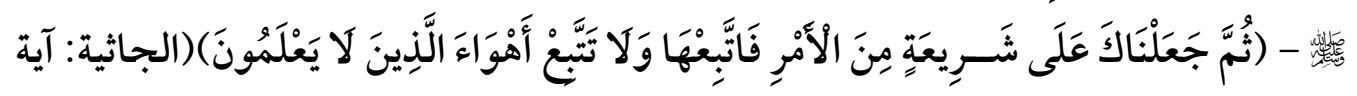

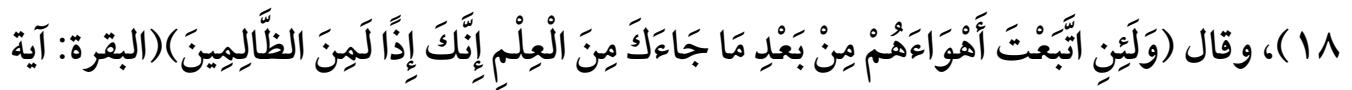

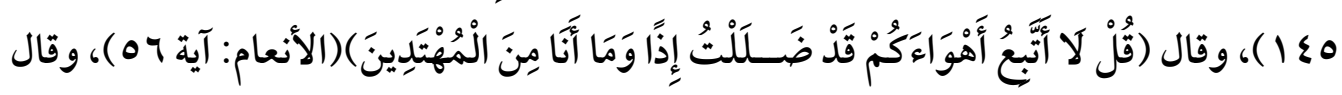
سـبحانه وتعالى مخحاطبًا عباده المؤمنين ومحذذرًا لهم من اتباع الهوى (فَلَا تَتَّبعُو الْهَوَى أَنْ

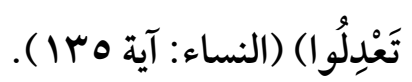

بـ تلييس الشيطان: وهو من الأسباب الخفية الباعثة لأهل التكفير على تكفير المسلمين ظلمًا وعدوانًا فإن الشيطان بكيده ومكره قد لبس عليهم في هذا الأمرأ وزينه في قلوبهمَّ فظفر منهم بما أراد من تحمل مظالم العباد من سفك للدماء واعتداء على المحارمٌّواستباحة لأموال المسلمين بغير الحقاّ ولذا قال الإمام علي - رضي الله عنه - للخوارج بعد قتالهم:" بؤسًا لكمّ لقد ضركم من غركم فقالوا: يا أمير المؤمنين ومن غرهم ؟ قال: الشيطان وأنفس بالسوء أمارة غرتهم بالأماني وزينت لهم المعاصي "(1) كما ذكر الإمام ابن الجوزي تلبيس الشيطان على الخوارج| فقال بعد ذكر شئ من أخبارهم:" وإنما المقصــود النظر في حيل إبليس وتلبيسـهـ على هؤلاء الحمقى الذين عملوا بواقعاتهم| واعتقدوا أن علي بن أبي طـالب - كرم الله وجهـه - على الخطاًّ ومن معسه من المهاجرين

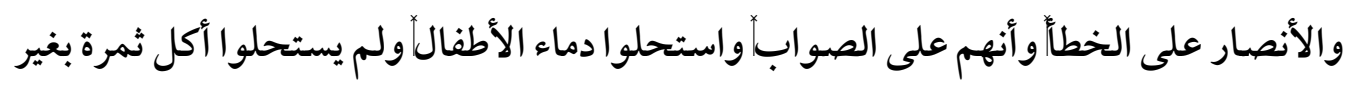
ثمنها "( (ن)

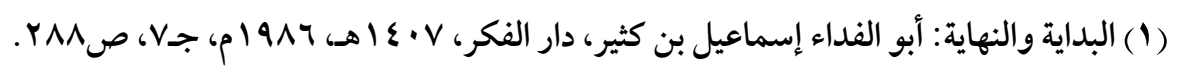

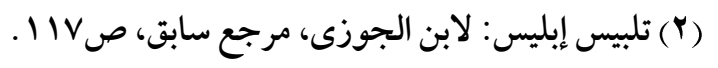




\section{المجلد السابع والثلاثثن إصدار ديسمبر 19.0.}

ك قللة العلماء المعتبرين: وذلك بسبب موتهم أو تقييد حرية البعض مما يؤدي إلى تنامي ظاهرة

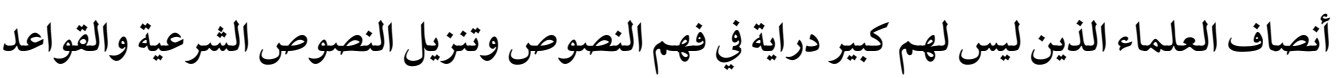

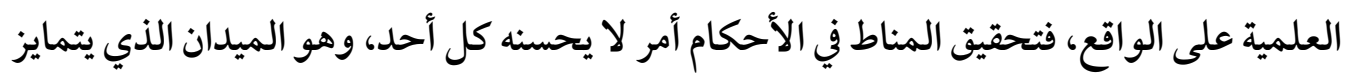

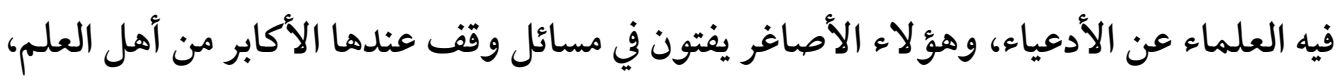

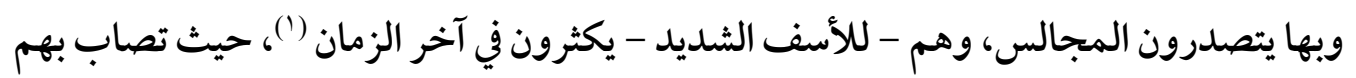

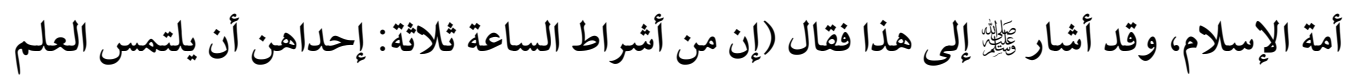

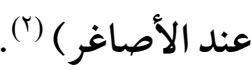

يقول ابن قتيبة:" لا يزال الناس بخير ما كان علماؤهم المشايخ، ولم يكن علماؤهم الأحداث، لأن الشيخ قد زالت عنه حِدَّة الشباب ومتعته وعجلته، واستصحب التجربة والخبرة، فلا يدخل

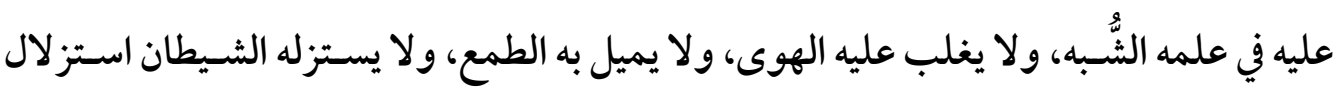

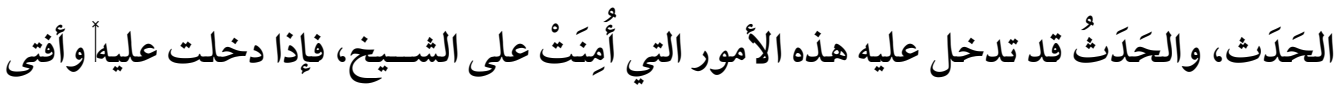

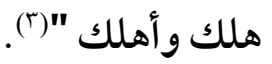

مـ التاويل الفاسل: يعد التأويل الفاسد للنصوص من أهم الأسباب الحقيقية الباعثة لأهل التكفير

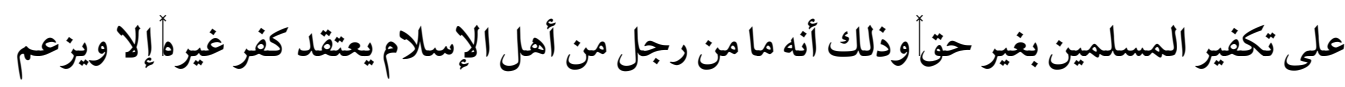

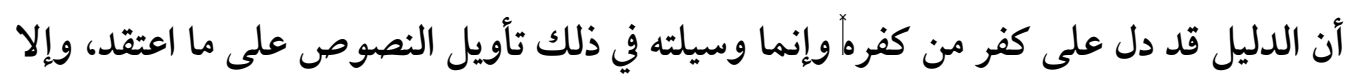

(1) التكفير وضوابطه: منقذ محمود السقار، رابطة العالم الإسلامي، ص9 ؟.

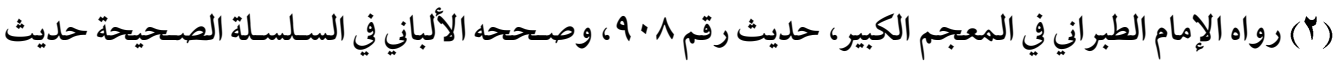

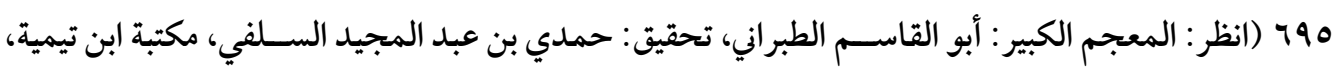
القاهرة، طY، جـ Y Y، ص آץr، وسلسلة الأحاديث الصحيحة: أبو عبد الرحمن محمد ناصر الدين الألباني،

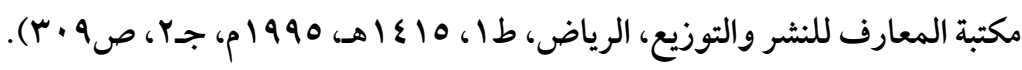
(r) نصسيحة أهل الحديث: أبو بكر الخطيب البغدادي، تحقيق: عبد الكريم أحمد الوريكات، مكتبة المنار،

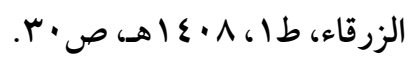


فالنصوص لا تعينه على معتقده الفاسد بل ترده، ولهذا عد العلماء التأويل الفاسد للنصوص سبب كل شر وفتنه وقعت في الأمة.

كما ذكر العلماء أن سـبب فتنة الخوارج فيما اعتقدوه من تكفير المســلمين إنما هو بسـبب التأويل| فعن الضحاك أنه قال:" أهل نهروان تأولوا آيات من القر آن في أهل القبلةً وإنما أنزلت في أهل الكتابلّ جهلوا علمها فسفكوا بها الدماء وانتهبوا الأموال وشهدوا علينا بالضلالة "( ). 1ـ اضطهاد حملة الفكر الإسلامي السليم، وقادة وأتباع الدعوة الإسلامية الملتزمة بالقرآن والسنة، والتضييق عليهم في أنفسهم ودعوتهم، ولا شك أن هذا الاضطهاد والتضييق لأصحاب الفكر الإسلامي الحر لايُولّد إلا اتجاهات منحرفة، تعمل في جو مغلق بعيدًا عن العلم الشرعي الصحيح، والنور الذي يشيعه العلماء الثقات، والحوار المفتوح. עـ قللح بضاعة هؤلائ الشباب الغيورين من ظقه الإسلام وأصوله، وعدم تعمقهم في العلوم الإسلامية واللغوية، الأمر الذي جعلهم يأخذون ببعض النصوص دون بعض، أو يأخذون بالمتثابهات وينسون المحكمات، أو يأخذون بالجزئيات ويغفلون القواعد الكلية، أو يفهمون بعض النصوص فهمًا سطحيًا سريعًا، فيتصدرون للفتوى في هذه الأمور الخطيرة، دون أهلية كافية، فالإخلاص وحده لا يكفي ما لم يسنده فقه عميق لشريعة الله وأحكامه، وإلا وقع صاحبه فيما وقع فيه الخوارج من قبل (`). وبعد فهذه جملة ما يوقع الناس في التكفير وما يؤدي إلى انتشـار وبائه، لكن العاقل إذاعرف الداء أصـاب الدواء، وتوخي موارد الزلل والهلاك بمزيد من الوقاية والحذر، حيطة لدينه وطلبًا

(1) معالم التنزيل في تفسير القرآن (تفسير البغوي): أبو محمد الحسين البغوي، تحقيق: عبد الرزاق المهدي،

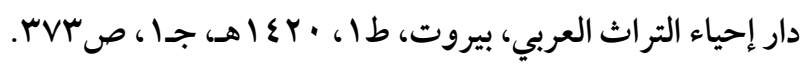

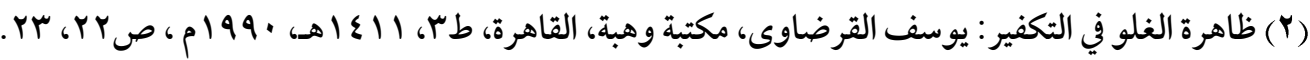


الآثار المترتبل على التكفير: تزداد خطورة التكفير وتظهر بصورة أكثر وضوحًا فيما يترتب عليه من آثار، فالحكم بالكفر على شخص يترتب عليه آثار دنيوية وأخروية.

\section{اولأ: الآثار الدنيوية:}

1 - أنه يجب أن يُحاكم أمام القضـاء الإسـلامي من أجل تنفيذ حكم الردة عليه وهو القتل كما

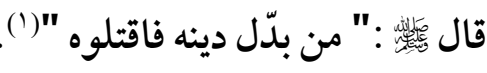

وفي هذا استباحة لدم المسلم الذي الأصل فيه التحريم والعصمة، لقوله المسلم حرام دمه وماله وعرضه "().

ץ- تحريم زوجته عليه، ووجوب التفريق بينه وبين امر أته، لأنها مسلمة وهو كافر، ولا يجوز له له

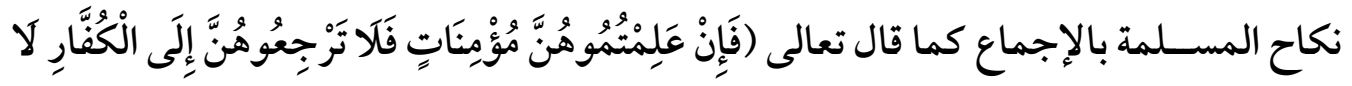

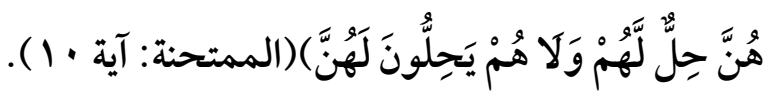

ץ- سقوط ولايته على أولاده لأنه كافر، فلا يجوز أن يبقوا اتحت سلطانه، لأنه لا يؤتمن عليهم،

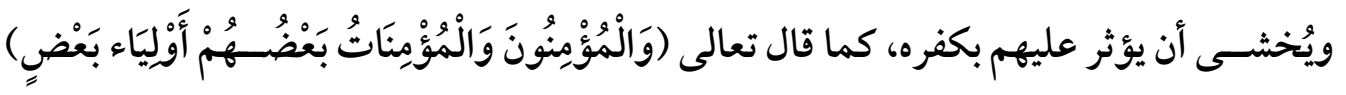

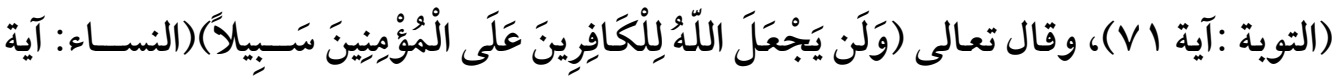
إ ( )، كذلك تبطل ولايته على المسلم في صور كثيرة، فلا يجوز أن يكون الكافر وليًا أو حكمًا أو قاضيًا أو إمامًا للمسلمين، إلى غير ذلك من صور الولاية المختلفة.

ع - انقطاع التوارث بينه وبين أقاربه، فلا يرثهم ولا يرثونه، فإنان اختلاف الدين مـانع من

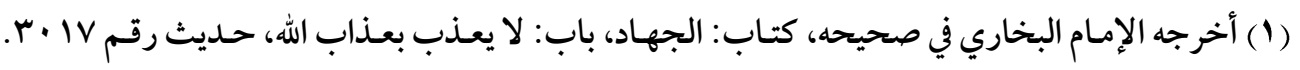

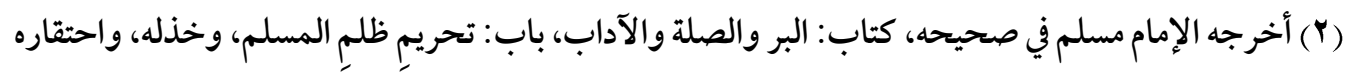

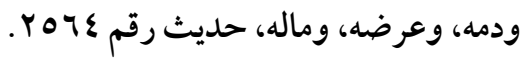




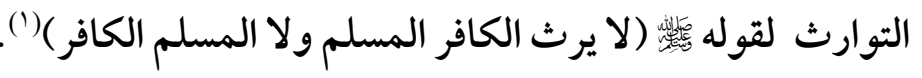

ه - تحريم محبته ومودته، ووجوب المقاطعة والهجر له حتى يتوب ويعود إلى الإسـلام، قال

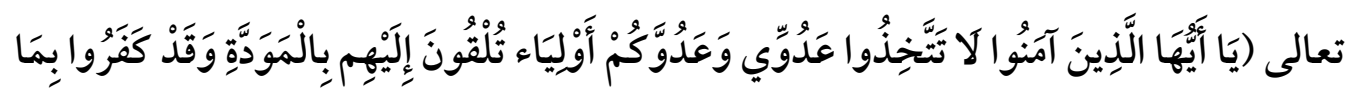

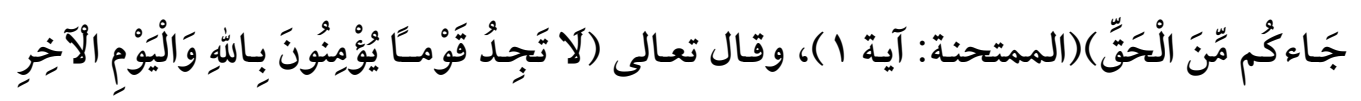

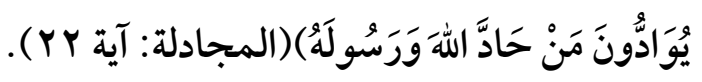

ج - عدم جريان أحكام المسـلمين عليه عند موته فلا يغسـل ولا يصـلى عليه ولا يدفن في مقابر

المسلمين ولا يستغفر له، وهذا من تمام البراءة من المشركين في محياهم ومماتهم، قال تعالى

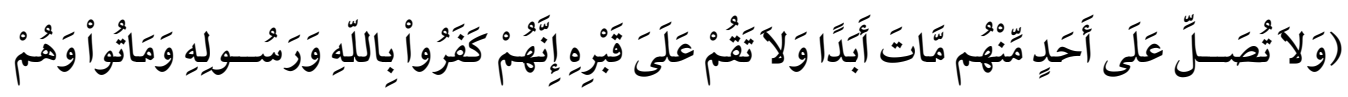

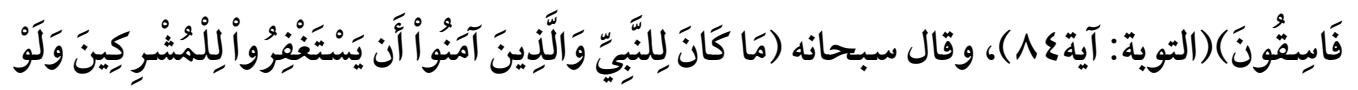

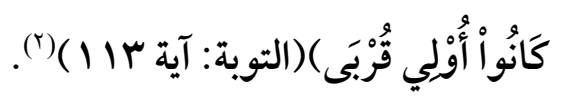

\section{ثُانيًا: الآثثار الأخروية :}

يترتب على تكفيره وموته على الكفر الحكم عليه بالعذاب واللعنة والخلود في النار، وحبوط

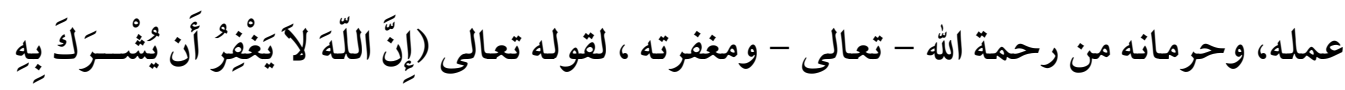

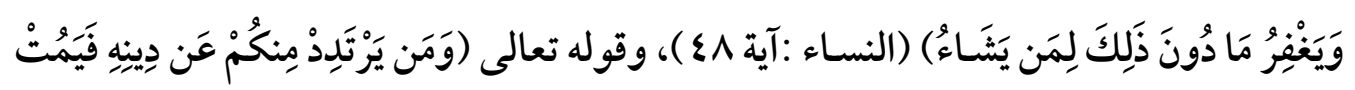

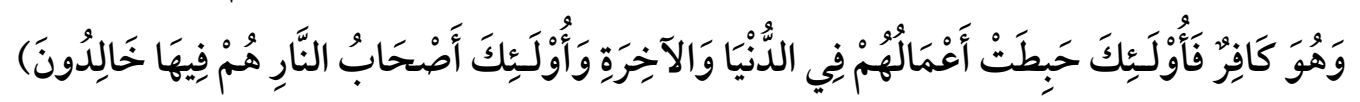

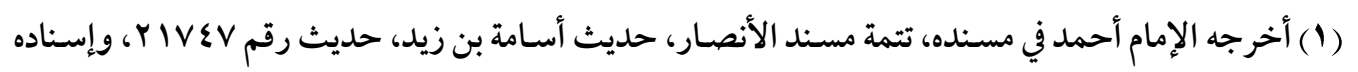

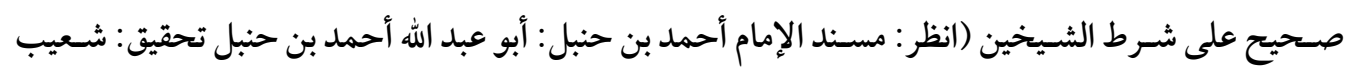

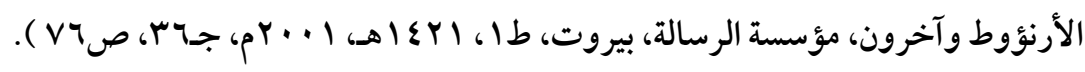

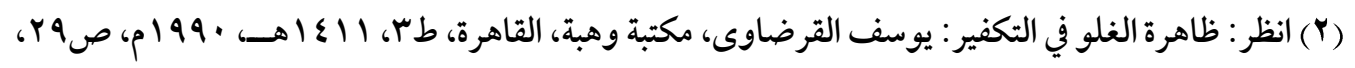

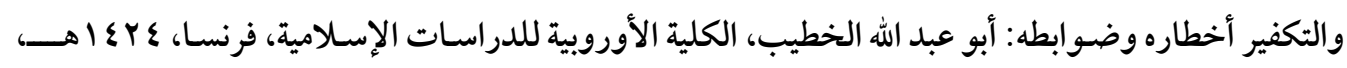

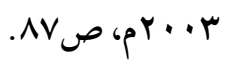


ولهذا فإننا نرى أن هذه الآثار إذا ثبتت على حكم التكفير غير الصسحيح، فما أعظم الأضــرار

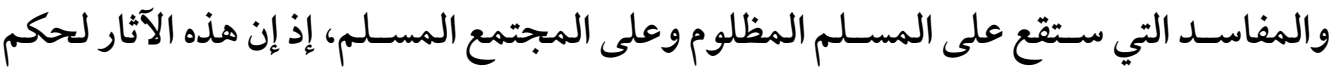
التكفير الجائر إنما هي بغى وظلم وعدوان علي صـاحبها من جهة، وتمزيق لأواصــر الأمة الإسلامية، وغرس لبذور الشقاق والخلاف في المجتمع المسلم من جهة أخرى. عقيدة أهل السنة أنه لا يحكم على الشخص بالكفر حتى تجتمع فيه جميع شروط التكفير، من

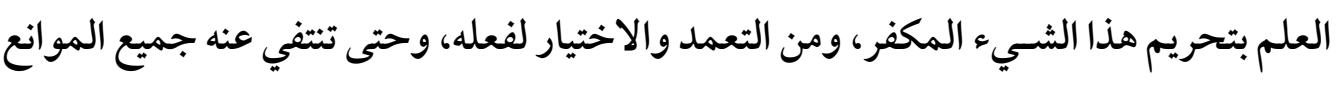

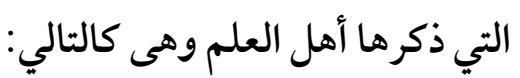

اــ الجهل: وهو خلو النفس من العلم، فالعذر بالجهل من موانع التكفير الذي يرفع به هذا

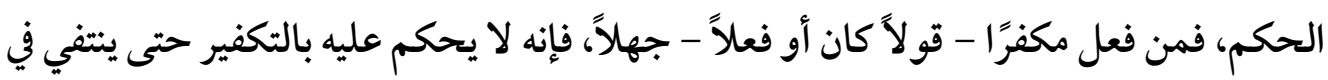

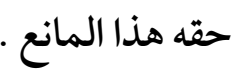

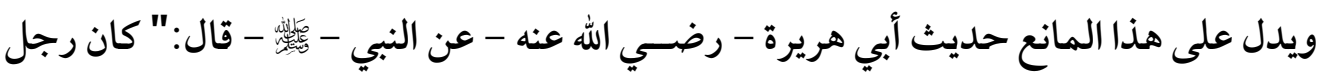

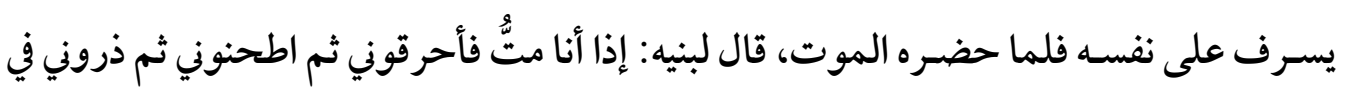

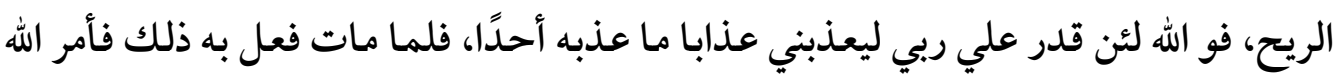
الأرض فقال اجمعي ما فيك منه، ففعلت، فإذا هو قائم، فقال ما حملك على ما صـنعت ؟ قال : يا رب خشسيتك فغفر له "(()، فهذا الرجل جهل قدرة الله عز وجل، فظن أنه إذا أحرق ونثر رماده في البر والبحر، فإن اله لا يقدر على جمعه، ولا شك أن الشك في قدرة الله - تعالى - كفر، ولكنه

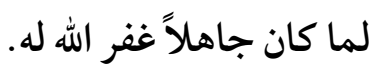

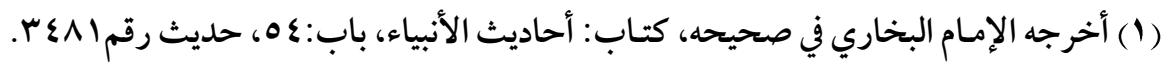


لكن ليس كل جهل يعذر صـاحبه، وإلا لعطلت الحدود واعتذر كل من قارف فعلاً مكفرًا بالجهل|ّولو عذر كل جاهل بجهله لفضل الجهل على العلم، كما قال الإمام الشافعي - رحمه الله - :" لو عُذِرَ الجاهل لأجل جهله لكان الجهل خيرًا من العلم، إذ كان يحط عن العبد أعباء

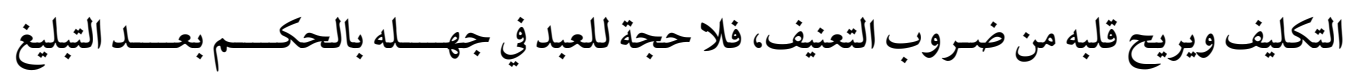
والتمكين، لئلا يكون للناس على الله حجة بعـد الرُسل "(1).

فالعذر بالجهل إنما يقبل في حق من كان في محلٍ أو حالٍ هو مظنة أن يجهل هذه الأحكام، كمن نشأ في بادية بعيدة أو كان حديث عهد بكفر، أما من عاش بين المسلمين، يحضر صلو اتهم ويسمع خطبهم، ثم يجهل شيئًا من أصول الدين أو أمرًا معلومًا منه بالضرورة فلا يعذر بجهله، لأنه متسـبب في وجود جهله وعدم إزالته، فالعذر بالجهل حيث إنه مانع من التكفير ليس على إطلاقة فهناك قضايا و أحوال لا يعذر فيها بالجهل.

rـ التاويل: وهو وضـع الدليل الشـرعي في غير موضعه باجتهاد أو شبهة تنثأ عن عدم فهم دلالة النص، فإذا اعتقد المسلم أو فعل أو قال أمرًا مكفرًا، وكان عنده شبهة تأويل في ذلك، فإنه يُعذر بذلك، فلا يكفر حتى تقام عليه الحجة .

وقد حكي بعض العلماء إجماع أهل الســة على هذا المانع، فقال الإمام الثــافعي - رحمه الله:" لم نعلم أحدًا من سلف هذه الأمة يقتدي به ولا من التابعين بعدهم ردّ شهادة أحد بتأويل،

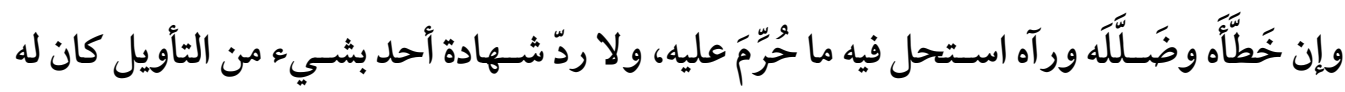
وجه يحتمله، وإن بلغ فيه استحلال الدم والمال أو المُفِرِّط من القول "(T)، وقال ابن حجر :" قال

(1) المثثور في القواعد الفقهية: أبو عبد الله بدر الدين الزركثـي، وزارة الأوقاف الكويتية، الكويت، ط؟، ما

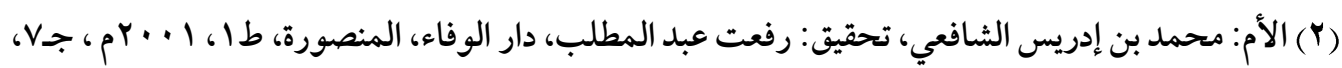
( ) 
العلماء كل متأول معذور بتأويله ليس بآثم، إذا كان تأويله سـائغًا في لسـان العرب وكان له وجه

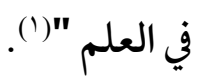

ومن خلال ما ســبق يتضــح لنا أن التأويل المعتبر في هذا المقام هو ما كان له وجه في الثــــع واللغة العربية، أما إن كان لا يعتمد على شـيء من القرائن الثــرعية أو اللغوية فهو غير معتبر

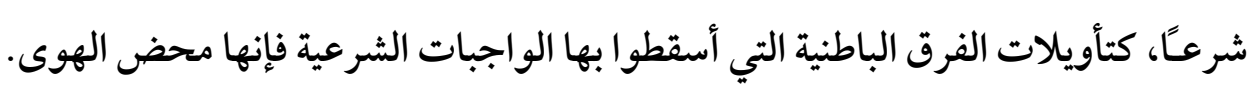
rـ الإكراه: وهو إلزام وحمل الغير على أمر يمتنع عنه ولا يريده، بتخويف يقدر الحامل على

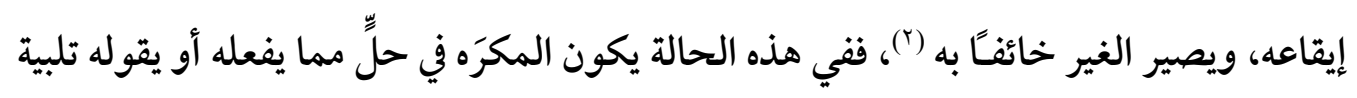

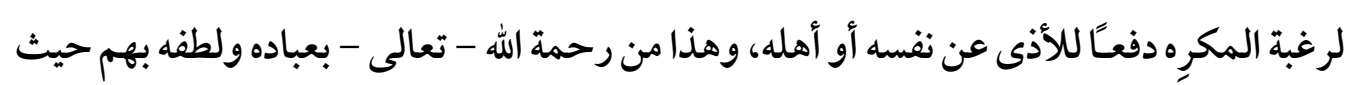
لم يكلفهم ما يشق عليهم. فإذا قال المســلم أو فعل أمرًا مكفرًا مخرجَا من الملة وهو في ذلك مكرها على قتل أو ضــرب يؤدي إلى إتلاف نفس أو نحوه، فإنه يعذر بذلك ولا يكفر وإن كان قوله أو فعله مكفرًا، ويدل

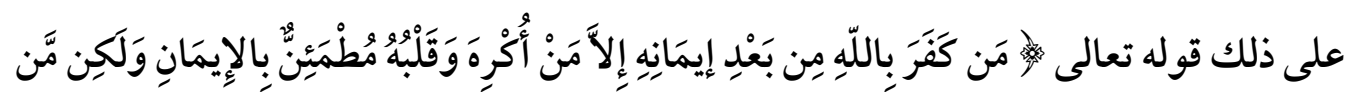

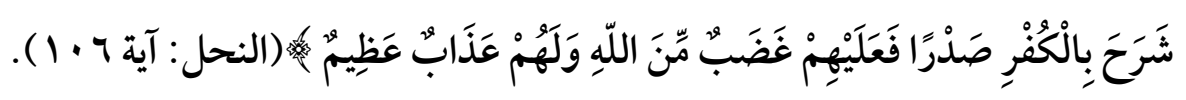
قال ابن العربي:" لما سـمح الله - تعالى - في الكفر به، وهو أصـل الثـريعة عند الإكراه، ولم يؤاخذ به، حمل العلماء عليه فروع الثــريعة، فإذا وقع الإكراه عليها لم يؤاخذه به، ولا يترتب

(1) فتح الباري شـرح صسحيح البخاري: أحمد بن حجر العسـقلاني، تحقيق: محب الدين الخطيب، رقم كتبه

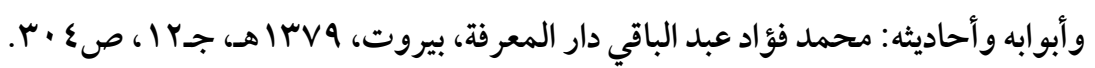

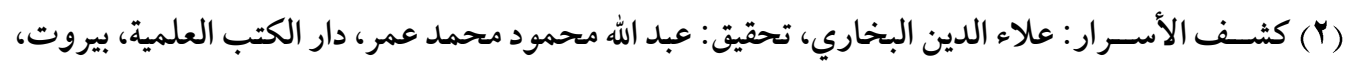
(b 
كـ الغطا: وهو أن يقصد بفعله شيئًا فيصادف فعله غير ما قصد، كمن يريد رمي غزالٍ فيصيب

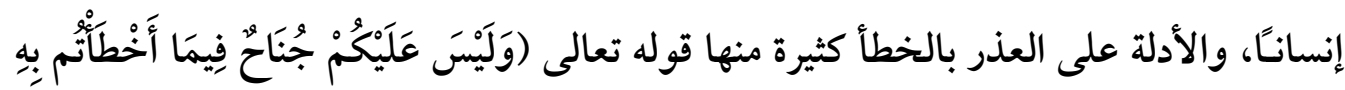

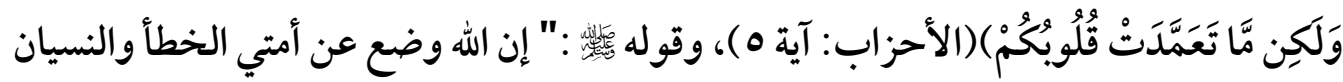
وما استكرهوا عليه "(()، وهذا عام في العذر من عموم الخطأ. وثمة دليل خاص يدل على العذر من الخطأ في مسـألة التكفير، وهو ما رواه مسـلم عن أنس بن

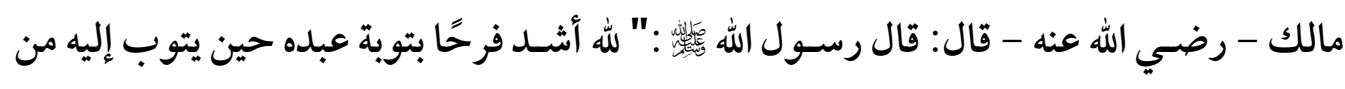

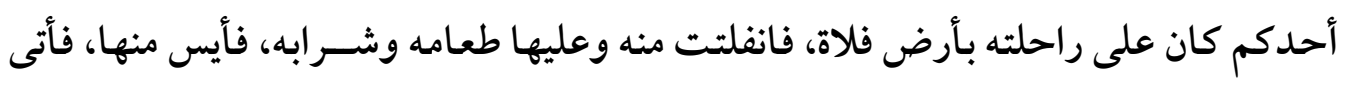

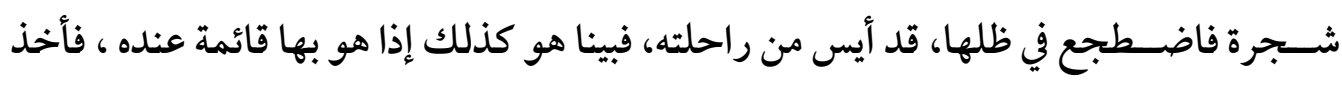

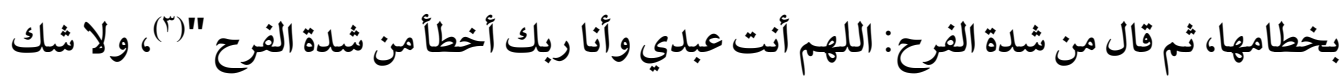

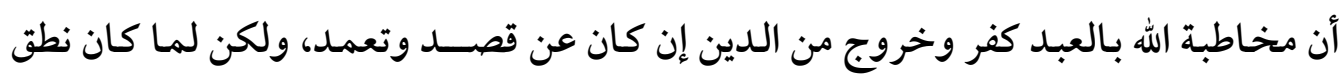
الرجل لها خطأ كان معذوراً بخطئه ولا يكفر.

تلك هي موانع التكفير، وهي تدلنا على مبلغ حرص الشـرع على وجوب التحقق من وقوع

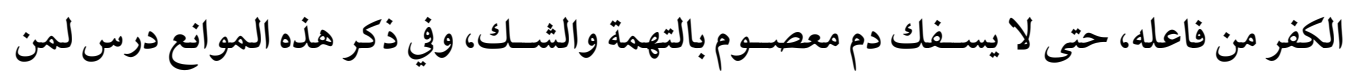

(1) أحكام القرآن: القاضسي محمد أبو بكر بن العربي، تحقيق: علي محمد البجاوي، دار إحياء التراث العربي،

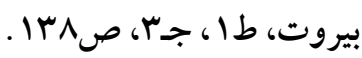

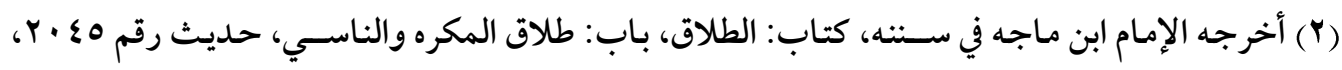
وصسحه الإمام الألباني (انظر: سـن ابن ماجن فاجه: الإمام ابن ماجة، تحقيق: محمد فؤاد عبد الباقي، دار إحياء

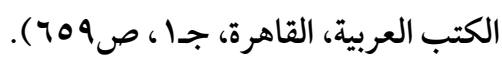
(ب) أخرجه الإمام مسـلم في صسحيحه، كتاب: التوبة، باب: في الحض على التوبة والفرح بها، حديث رقم 
المجلد السابع والثلاثّن إصدار ديسمبر 19.0.

يمارسون التكفير دون اعتبار لتوافر شروط التكفير وانتفاء موانعه .

\section{الخوارج وظظاهرة التخغير:}

إن ظاهرة التكفير ليست جديدة على المجتمع الإسـلامي، بل إنها تمتد إلى العصر الإسـلامي الأول، وتحديدًا إلى ما بعد معر كة صِفِّين (') ونشــوء فرقة الخوارج، والتي يمكن اعتبارها أول حركة تكفيرية ودموية عرفها التاريخ الإسلامي.

فكان أول من أظهر بدعة التكفير بغير وجه حق هم الخوارج، حيث جعلوا من التكفير أسـاسًا لعملهم السياسي والديني، قال شيخ الإسلام ابن تيميه:" والخوارج هم أول من كفَّر المسلمين،

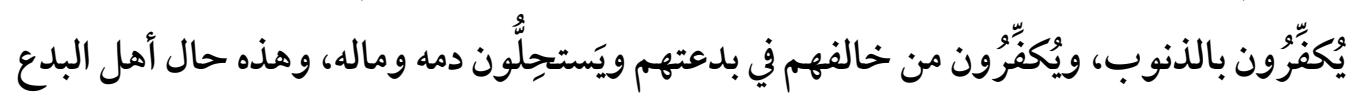
يبتدعون بدعة ويُكفِّرون من خالفهم فيها "(؟).

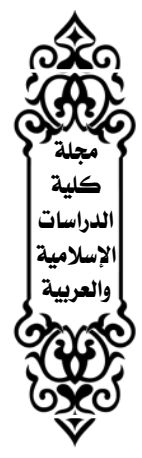

وكان هذا في معر كة صِفِّن، والتي كانت بين جيش على وجيش معاوية رضي الله عنهما، حيث

بدأت عندها الأحداث التي تفجر منها الوجود الخارجي بفكره ومبادئه وقواعده، وفى مقدمتها التكفير.

والخوارج كانوا في البداية من أنصـار الإمام على، ومن المقاتلين تحت رايته، والمؤيدين له، وفى معر كة صِسفِّن حين طلب معاوية - رضــي الله عنه - إيقاف القتال واللجوء إلى التحكيم لتصـفية النزاع الدموي، وكان رأى الإمام على - رضسي الله عنه - اسـتمرار القتال، لكن جيثـه

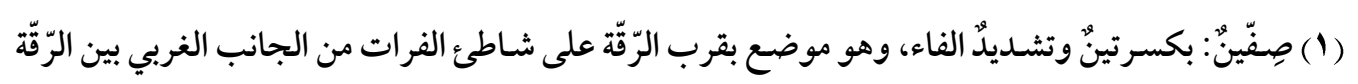

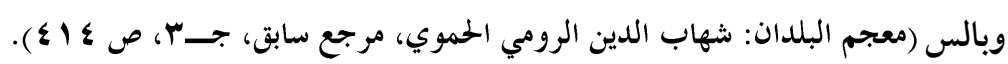

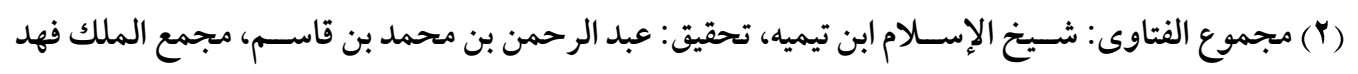

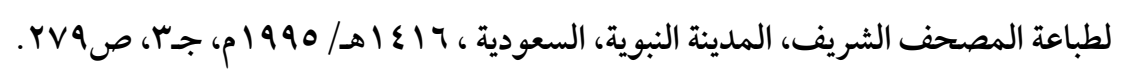


رفض وطالب بقبول التحكيم، فاضطر الإمام على لذلك (').

بل وصـل بهم الأمر إلى تهديد الإمام على - رضسي الله عنه - بأن قالوا له:" يا علي، أجب إلى

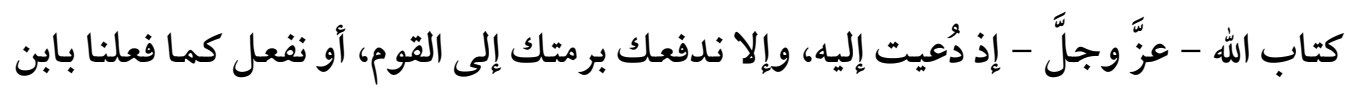
عفان .... والله لتفعلنها أو لنفعلنها بك "(().

لكن ما أن أعلن الإمام على - رضسي الله عنه - ذلك، حتى خرج من جيشـهـ جماعة ترفض التحكيم، وليت الأمر وقف عند هذا الحد، بل بالغوا في الإنكار على الإمام على، وقالوا له : حكمت الرجال في كتاب الله، لا حكم إلا لله، ومن حكّم غيره فقد كفر، فرد عليهم الإمام بقوله : كلمة حق أريد بها باطل (). ثم بعد ذلك قادهم الشـيطان وحملهم على إنكار إمامة عثمان - رضي الله عنه - في المدة التي نقم عليه أعداؤه فيها، كما أنكروا إمامة على - رضي الله عنه - أيضـا بعد التحكيم، بل أدى بهم سـوء معتقدهم إلى تكفير هما، وتكفير طلحة والزبير ومعاوية وعمرو بن العاص وأبى موسسى الأشعري وعبد الله بن عباس رضي الله عنهم، وأصحاب الجمل وصفين. وهكذا نبتت أول بدعة في تكفير المسـلمين، وقد دَوّن أهل العلم هذا المعتقد السـيئعنهم في كتبهم، فقال الإمام الأشسعري:" والخوارج بأسـرها يثبتون إمامة أبى بكر وعمر، وينكرون إمامة عثمان رضـــوان الله عليهم في وقت الأحداث التي نقم عليه من أجلها، ويقولون بإمامة على قبل أن يحكم، وينكرون إمامته لما أجاب إلى التحكيم، ويكفِّرون معاوية وعمرو بن العاص وأبـا

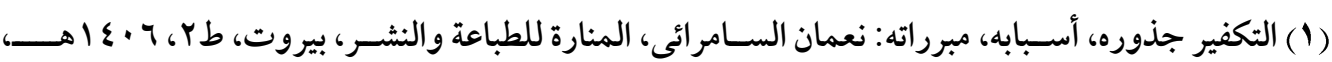
rVDapl919T

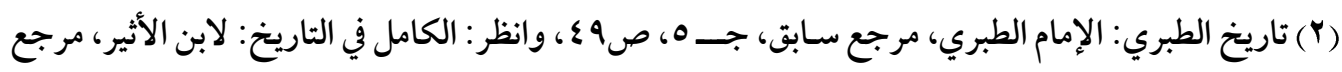
سابق، جr، ص^זr.

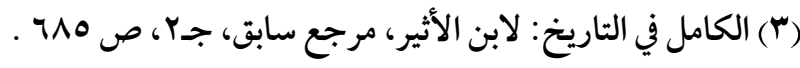


وقال الإمام الثــهرســانى:" ويجمعهم القول بالتبرئ من عثمان وعلي رضـي الله عنهما،

ويقدمون ذلك على كل طاعة "(؟).

ثم وصلت ظاهرة التكفير عند الخوارج إلى منعطف خطير، حيث استخدموه وسيلة لإرهاب المجتمعات الإســلامية وبث حالة من الرعب فيها، وقد نجم عن ذلك فتح باب الصــراعات السياسية والاختلافات الفكرية، التي أدت فيما بعد إلى ظهور فرقٍ وأحزابٍ وحر كات سياسية، وبالغ الخوارج في تكفير المســلمين وغالو افي ذلك إلى درجة أن أصــح هذا التكفير مبداً يميز الخوارج عن غيرهم من الفرق الإسلامية الأخرى.

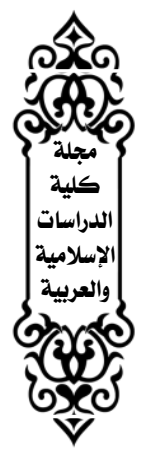

فقد اشتهروا بتكفير أصحاب الكبائر، ونقل عنهم أصحاب المقالات في هذه الظاهرة عقائدهم الفاسـدة وتناقضـاتهم، واختلافهم في تحديد الذنب الذي يُكّفر صـاحبه به إذا ارتكبه، فمنهم من يكفر بالكبائر وهو المشهور عن جملتهم، ومنهم من يكفر بكل ذنب. قال أبو الحسـين الملطى:" والثُّـراة (وهم الخوارج) كلهم يكفرون أَضْـَحَاب الْمعاصِسي وَمن خالفهم فِي مَذْهَبهم مَعَ اخْتَِّاف أقاويلهم ومذاهبهم "((َ). وقال الثـهرسـتانى:" ويكفرون أصسحاب الكبائر ويرون الخروج على الإمام إذا خالف السـنة

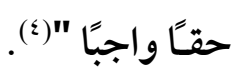
وقال ابن حزم:" ومن وافق الخوارج من إنكار التحكيم، وتكفير أصسحاب الكبائر، والقول

$$
\begin{aligned}
& \text { (1) مقالات الإسلاميين واختلاف المصلين: أبو الحسن الأشعري، مرجع سابق، صه 1 ا. }
\end{aligned}
$$

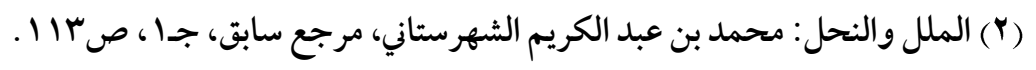

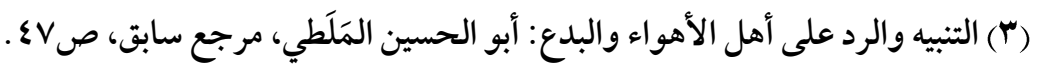

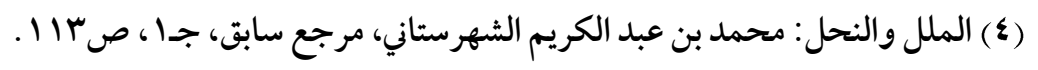


بالخروج على أنمة الجور، وأن أصسحاب الكبائر مخلدون في النار، وأن الإمامة جائزة في غير قريش فهو خارجي، وإن خالفهم فيما عدا ذلك مما اختلف فيه المسـلمون - وإن خالفهم فيما

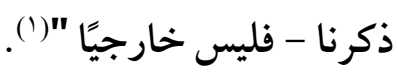

ومن خلال ما سـبق يتضــح لنا مدى التفاوت الكبير في تحديد الخوارج للذنب الذي يكّفر به وتناقضهِم واختلافهم، وهذا من البراهين على بطلان مذهبهم، كما قال تعالى (وَلَوْ كَانَ مِنْ عِنْدِ

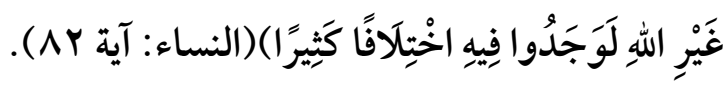

\section{وقل انطلق الخوارج في تكميرهم هدا من منطلقين (†):}

الأول: هو مقتضى مبدؤهم في الإيمان، فهو عندهم: اعتقاد بالقلب، وإقرار باللسان، وعمل بالجوارح، قال ابن حزم:" وجميع الخوارج إلى أن الإيمان هو : المعرفة بالقلب بالدين، والإقرار

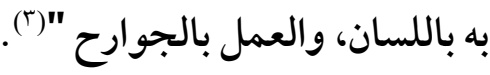
وإذا كان هذا الر أي هو مذهب الكثير من الفرق الأخرى، إلا أن الخوارج انفردوا بما يترتب على ذلك، إذ الإيمان عندهم كل لا يتبعض، فمن ترك ركنًا من أر كانه فقد سـلب منه كله، كما جعلوا أجزاء الإيمان التي يتركب منها متساوية الأقدام، إذا زال بعضه زال كله. يقول العلامـة المُبَارَكْفُورِي:" وقال الخوارج والمعتزلة: تـارك الأعمال خـارج من الإيمان، لكون أجزاء الإيمان المركب متســاوية الأقدام في أن انتفاء بعضـهـا - أيٌّ بعض كان - يسـتلزم انتفاء الكل، فالأعمال عندهم ركن من أر كان الإيمان كأركان الصلاة، ثم اختلف هؤلاء، فقالت

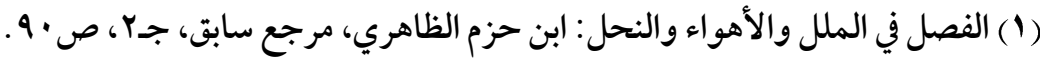

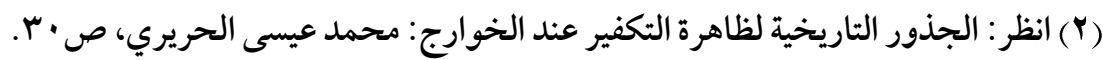

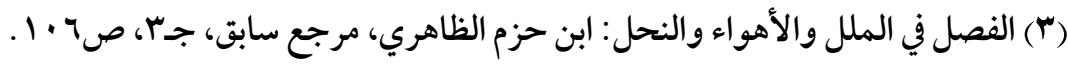


الخوارج: صاحب الكبيرة وكذا تارك الأعمال كافر مخلد في النار"(().

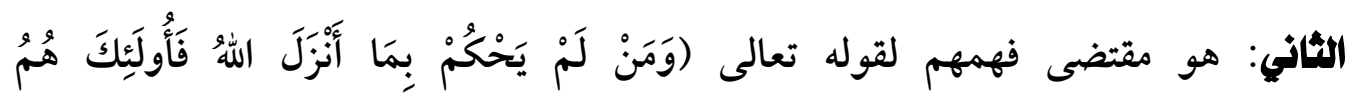
الْكَافِرُونَ)(المائدة: آية؟ § )، فاعتقد الخوارج أن كل مخالفيهم في مذهبهم ومبادئهم حاكمون بغير ما أنزل الله، واعتقدوا بيقين أن مذهبهم هو المذهب الحق الأوحد، وراحوا تطبيقًا لهذا يتصيدون ما اعتبروه أخطاء ارتكبها هؤ لاء المخالفون ليحكموا عليهم بالكفر. وترتب على هذا أن أصـبح للخوارج مسـلكان: الأول: تكفير مرتكب المعاصسي والذنوب من المسلمين، والثاني: تكفير مخالفيهم عامة سواء كانوا حكامًا أو محكومين. وإذا كان أصـل هذه البدعة الضــالة قد انحدر من الخوارج ومن أفكارهم المنحرفة، إلا أنه لا يزال داء التكفير بغير برهان، ولا مسـتند شـرعي، ينتقل من طائفة إلى طائفة من أهل البدع،

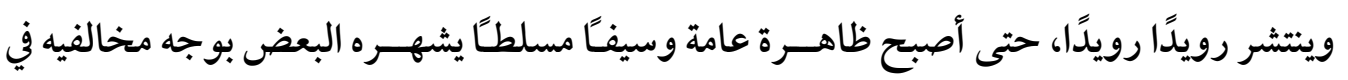

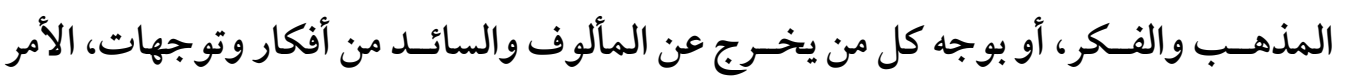
الذي شوّه صورة الإسـلام وأضعف المسلمين وحوّلـهم إلى مللٍ متنـاحرة وفرقٍ متناثرة.

\section{كيفية علاج هده الظاهرة:} إن علاج هـذه الظاهرة لا يكون بإلقاء الخطب والمواعظ، ولا بعقد المؤتمرات والندوات، دون أن يتبعها إجر اءات عملية، وإن العلاج بالعنف المضاد لا يولد إلا التطرف، يقول رسول الله ـ ـ ـ ـ إن الله رفيق يحب الرفق، ويعطي على الرفق ما لا يعطي على العنف، وما لا يعطي على

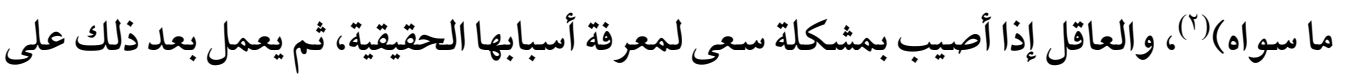

(1) مِرْعَاة المَفَاتِيحِ شرح مشكاة المصابيح: أبو الحسن المبار كفوري، إدارة البحوث العلمية والدعوة والإفتاء،

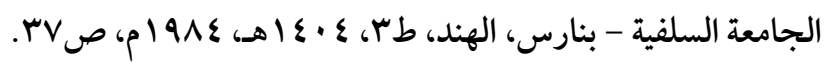

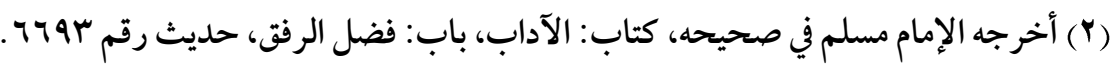


إزالة هذه الأسباب وإصلاح ما يمكن إصلاحه من الخلل.

ونحن الآن أمام خطر كبير يدمر الحرث والنسـل، ويحرق الأخضــر واليابس ويقتل الإنســان لمجرد أن يختلف معه في الرأي وهـذا خلاف مـا جـاء بـه الإســلام الداعي للحرية والتعـايش والانفتاح على الآخر دون تمييز في عرق أو دين أو لون، والسـؤال المطروح كيف نواجه هذا الخطر والمرض المستشري في جسد الأمة ؟

لكن قبل الحديث عن علاج الفكر التكفيري هذا أود أن أشـير إلى بعض النقاط المهمة بين

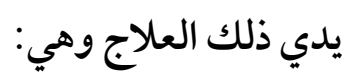
1 - أن التكفير مرض من الأمر اض المنتشـرة في جســم الأمة عبر التاريخ، وما من مرض إلا وله دواء، عرفه من عرف، وجهله من جهل، وقديما قال الشاعر :

لكل داء دواء يستطب به إلا الحماقة أعيت من يداويها(')

ץ - أننا إذا أردنا علاج تلك المشـكلة الخطيرة فلا بد من تفادي وتجنب الأسـباب التي أدَّت إلى هذه الحالة - قدر المسـتطاع -، انطلاقتَّ من المقولة القائلة: الوقاية خيرٌ من العلاج، فالفكر التكفيري - قديمه وحديثه - لم ينثــأ من فراغ، ولم يأت جزافتًا، وإنما له أســبابه ومســبـاته المتعددة والمتنوعة، والتي سبق أن أشرنا إليها . بـ- أن علاج هذه الظاهرة مسؤولية مشتر كة لدى الجميع، كلّ في موقعه: حكَّام، وعلماء، ودعاة، وبقية أفراد المجتمع، فينبغي أن تتضافر الجهود في سبيل مواجهة هذه الظاهرة الخطيرة. والآن آن الأوان أن نعرض ما نراه علاجًا نافعًا ومعالجة تأصـيلية على ضــوء منهج الكتاب والسنة وسير السلف الصالح، ومن ذلك:

(1) العقد الفريد: ابن عبد ربه الأندلسي، دار الكتب العلمية، بيروت، طع • \& (، اهـ، جـr، صجYY. 


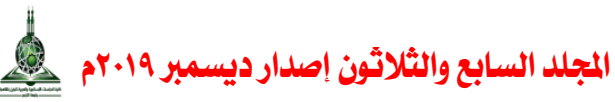

أولأ: نشر العلم الشرعي المستمد من الكتاب والسنة وسلف الأمة: فالانحر اف الفكري غالبًا ما

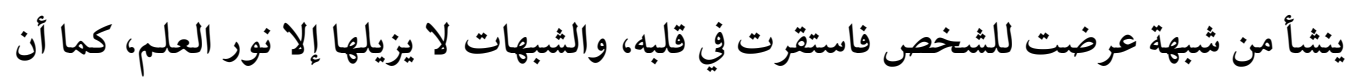

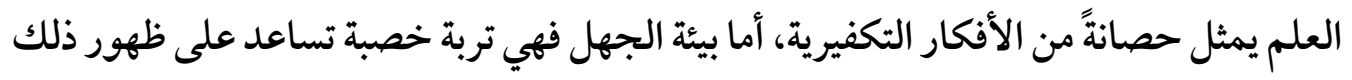

وتكمن أهمية هذا العلم في معالجة ظاهرة التَّكفير في كونه عليه المدار في إطلاق الأحكام

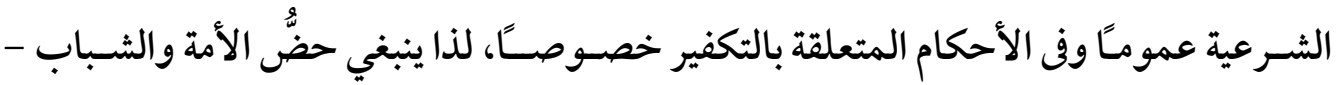

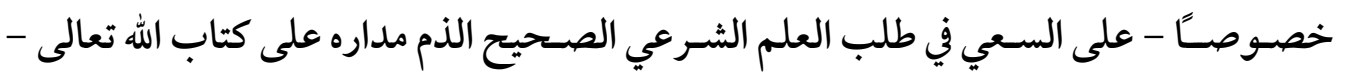

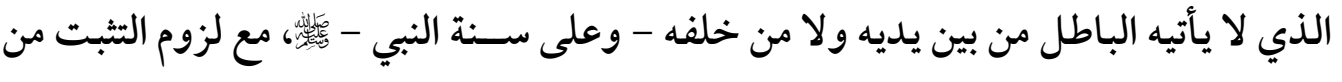

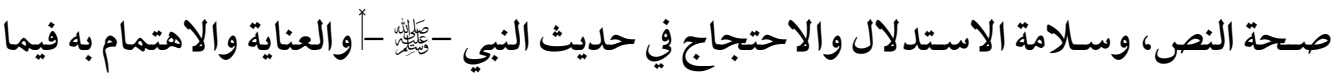

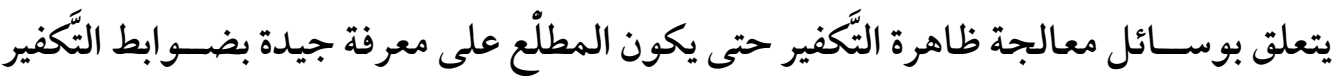
وحدوده ومو انعه وشـروطه، وهذا لا يتوفر إدراكه إلا لمن وفقه الله - عز وجل - للعلم بذلك، تلكيك.

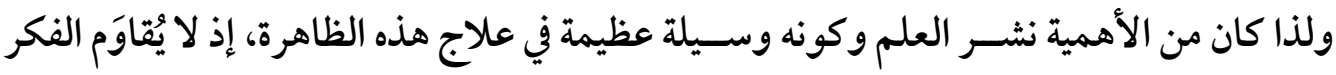

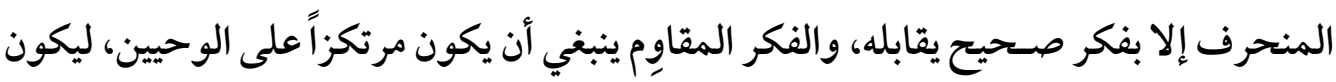
الردُّو العلاج محكمًا قويًا (1). ولا شك أن طلب العلم على وجهه الصحيح، وعلى من هو أهله يؤدى بفضل الله إلى الاحتراز

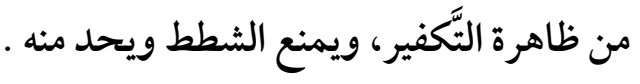
ثانيًا: الثفاف شباب الأمة حول العلماء الربانيين والثقة بهم وبفتاواهم: فالعلماء الربانيون هم

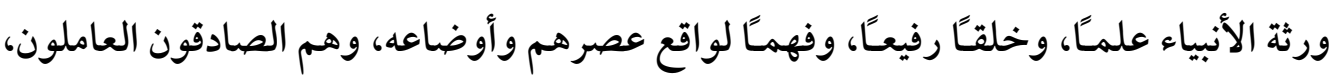

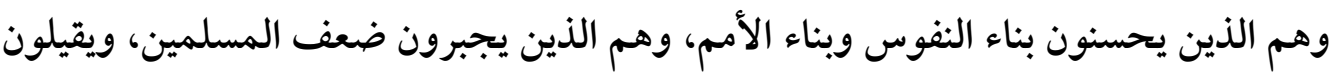

(1) وسائل علاج ظاهرة التَكفير : عاصم بن عبد الله القريوتي، دار العلم، السعودية، صT. 
الأمة من عثرتها، ويعيدون لها عزتها، فهؤلاء حاجة الأمة إليهم أشد من حاجتهم إلى الهواء

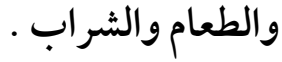

لكن ثمة فجوة واسعة أو شرخ كبير حدث بين الشباب الذين جنحوا إلى الفكر التكفيري وبين هؤلاء العلماء، يتمثل في ذلك الانفصـال الذي صـار بين العلماء وشـبـاب الدعوة، فالعلماء في مكان وشباب الدعوة في مكان آخر، ومع الأسف فقد تصدى للدعوة أناس ليسوا من أهل العلم الثــرعي والاجتهاد فضـلوا وأضـلوا، ومن ثم وقع كثير من هذا الثــبـاب فريسـة لهذا الفكر التكفيري.

أيها الثــباب ألا نذهب إلى الأطباء عندما نمرض ؟ ألا نذهب إلى المهندس المعماري عندما

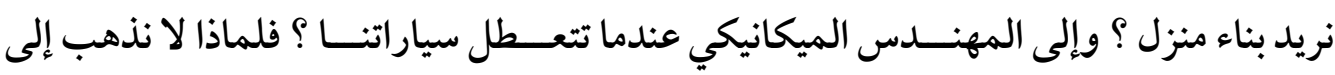
هؤلاء العلماء عندما تقع لنا مشكلات ونوازل دينية ؟ أليس الإصـلاح الديني أهم من الإصلاح

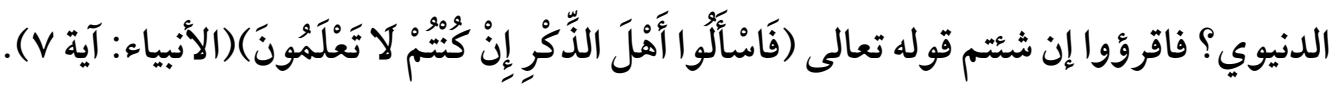
ومن هنا أطالب العلماء بـالاقتراب من هؤلاء الثـبـاب، كما ينبغي على الثــباب أن يثقوا بالعلماء، وعلى شـباب الدعوة أن يعرف قدر نفسـه ولا يغتر بتدينه، فهذه سـمة الخوارج الذين

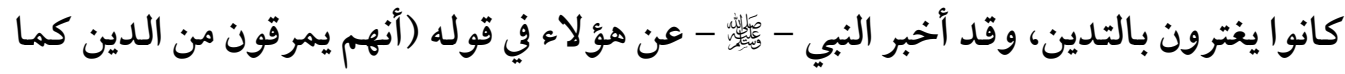
يمرق السهـم من الرمية) (')، أي يتعبدون بلا علم، ويجب أن يطبقوا قول الله تعالى (فَاَْأَّوا أَهْلَ

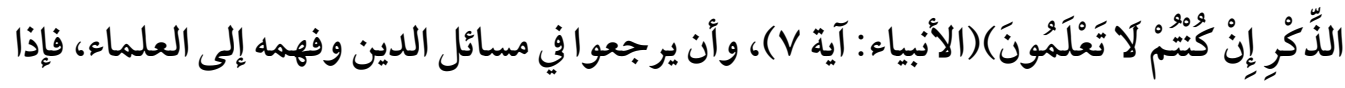
حدث التو اصل والاندماج بين العلماء وشباب الدعوة والأمة كلها، نستطيع - بعون الله تعالى أن نقضى على ظاهرة التكفير التي غزت بلدان المسلمين.

(1) أخرجه الإمام البخاري في صسحيحه، كتاب: اسـتتابة المرتدين والمعاندين وقتالهم، باب: قتل الخوارج والملحدين بعد إقامة الحجة عليهم، حديث • · 794. 


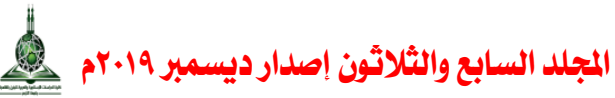

ثالثثا: العودة إلى الكتاب والسنة: فمن العلاج النافع التمسك بكتاب الله تعالى وبسنة رسول الله الذي يوزن بهما أيّ إنتاجٍ معرفيّ أو أيّ تراثٍ وثقافةٍة، فهما مصدر التشريع، وفيهما البيان الشامل، والجواب الوافي لمتطلبات حياتنا الدينية والدنيوية، فلا يقبل قول يبنى عليه اعتقاد إلا بدليل من الكتاب أو السنة وفق فهم سلف الأمة.

ولنكن على يقين كامل، وثقة مؤكدة، أنه لاعز لأمتنا ولا نصـر لها ولا كرامة إلا بهذه البداية،

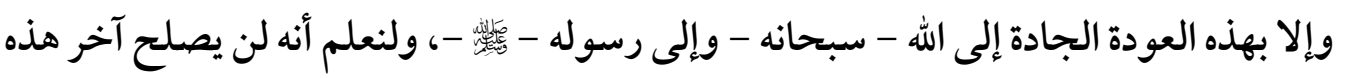

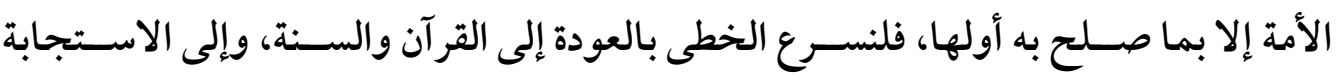

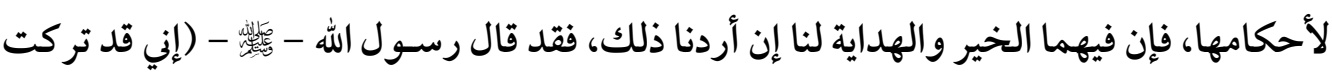

فمتى عدنا إلى الكتاب والسـنة فزنا وأفلحناً ومتى أعرضــا عنهما ضــللنا وشـقيناً وما كل ما

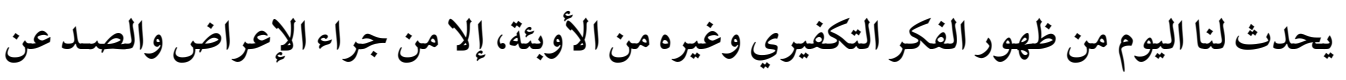

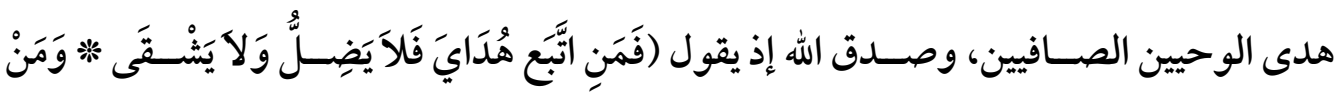

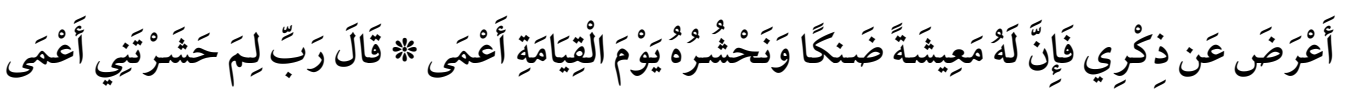

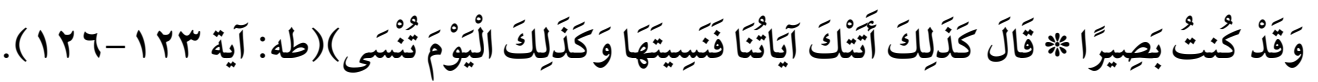
رابعاً: فتح باب الحوار والمناقشة العلمية: فالحوار هو الوسيلة التي تقبح جماح أي فكر منحرف

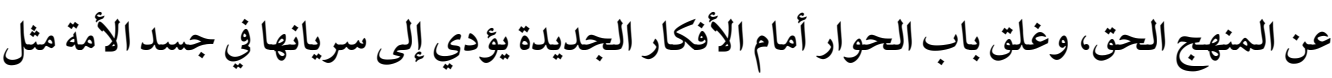

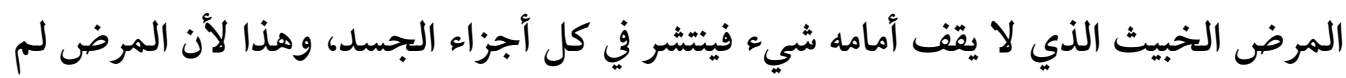

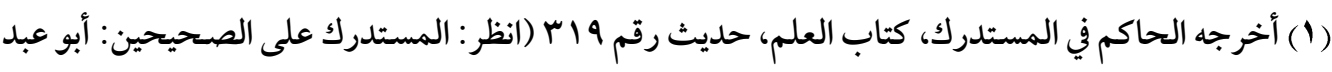

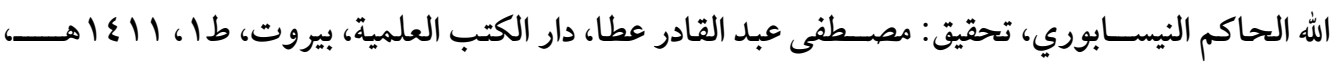

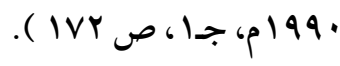


يتعامل معه منذ مولده، ومن ثم يعد هذا العلاج من أنفع وأنجح الأساليب، ولهذا لم يتر كه النبي الناس بدين الله، ولم يكن لأهل مكة حيلة يصرفون بها الناس إلا الغمز واللمز في النبي وإلقاء التهم عليه، وهذا دأب كل مبتدع ضال وكل كافر ملحد مع أهل الحق، ليس أمامه غير

التجريح واختراع تهم باطلة لصرف الناس عن الحق (').

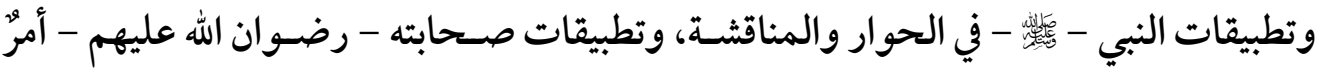

معلوم مدون في كتب السنة.

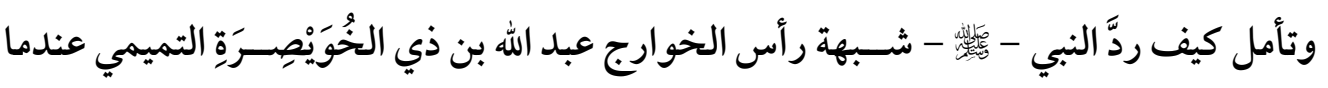
قـال له: اعـدل، فأجابه مباشرة بقولـه: ويلك ومن يعـدل إذا لم أعـدل ؟(؟)، وهذا هو المنهج نفسه الذي استخدمه علي بن أبي طالب وابن عباس - رضي الله عنهما - مع الخوارج لإقناعهم بالعدول عن آرائهم والعودة إلى حظيرة الأمة، فرجع منهم بسبب الحوار والمناظرة معهم أربعة آلاف كما جاء في بعض الروايات، وقيل ألفان (ॅ). إن أسلـــوب الحـــوار والمناقثـــة العلمية ينبغي أن يحتذى به ويقـــدم في معـالجة الأفكار المنحرفة والتعامل معها، فالفكـر يعالج بالفكـر، والحجـة لا تدحضها إلا حجـة أقـوى منها، كما أن الحوار مع أصحاب هذه الأفكار قد يكشف الكثير عن الأفكار التي تبدو غامضة، ولهذا يعتبر الحوار مفيدًا جدًا في إخراج أصسـحاب الفكر المنحرف من ســـن الترديد والتقليد إلى لى

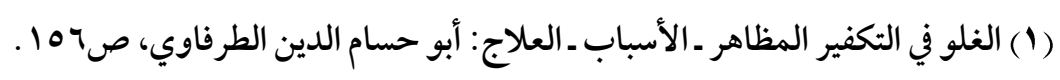

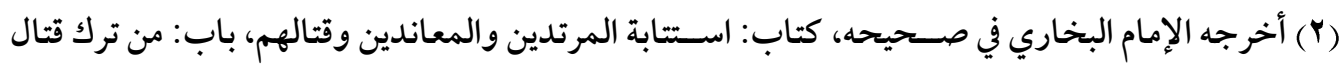

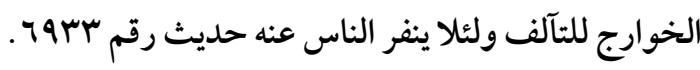
(r) البداية والنهاية: أبو الفداء إسـماعيل بن كثير، تحقيق: عبد الله بن عبد المحسـن التركي، دار هجر للطباعة

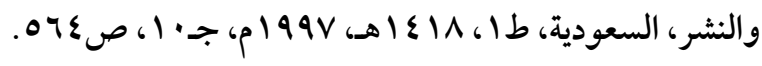


رحابة الفكر العقلي وسـماحته، فهو يفتح أمامهم آفاقَّا جديدة لم يكن مسـموحسَّ لهم بها داخل جماعاتهم، ويعينهم على استخدام ملكة العقل.

خامسأ: منع ومعالجة الفتاوى الفردية الثاذة في قضايا الأمة المصيرية: لأن الفتوى لها شأنها وخطورتها، فقد كثرت في هذا العصر فوضى الفتاوى الشاذة والمضطربة التي لا يضبطها ضابط، ولا يحكمها ميزان، وزاد في الطين بلة كما يقولون، سرعة انتشارها وذيوعها، بعد أن أصبح العالم قرية واحدة، بسبب ثورة الإعلام وانتشار وسائل الاتصال الحديثة، ولاسيما الفضائيات وما يُذاع فيها من فتاوى على الهواء.

لقد عانت مجتمعاتنا من الفتاوى والآراء الثــاذة، ولهث بعض المحسـوبين على العلماء من غير المؤهلين وغير المتخصسصسين ومن بعض ضسعاف النفوس المتطلعين للشـهرة أو الجاه أو حب الظهور، خلف كل شـاذ وغريب من الآراء، ليجذبوا بذلك الأنظار إليهم، أو ليخدموا به

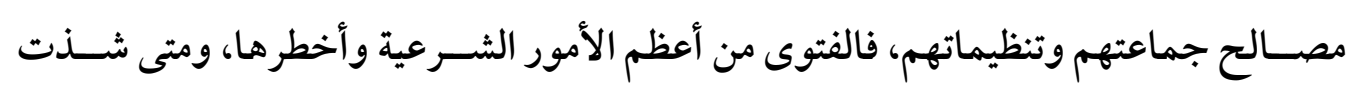

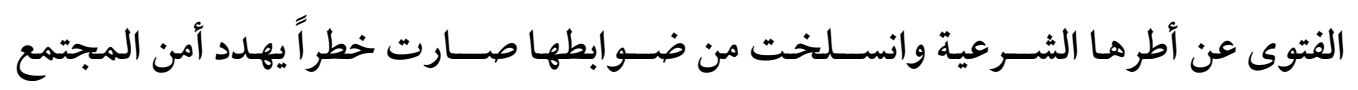
واستقراره، كما يهدد الأمن الفكري للأمم المجاورة، لأنها ترسم صورة مشوهة عن الإسلام. ولذا يجب وضع ميثاق لعملية الإفتاء ولوسائل الإعلام الإسلامية توافق عليه كل القنوات التي تتبنى برامج الإفتاء، تلتزم من خلاله بشروط وضوابط الفتوى والمفتين، والإحالة على المجامع الفقهية في حالة الفتاوى المشحَلَة دون التحرج من ذلك. كما أننا نرى أن الأمر قد بات أكثر إلحاحًا وضــرورة إلى تبني فكرة الاجتهاد الجماعي الذي يدعى إليه كبار العلماء، من مختلف دول العالم ممن يحملون هموم الأمة ومشكلاتها ليو اجهوا بشجاعة القضايا الخطيرة.

ولا شـك أن هذا الاجتهاد الجماعي سيسـهم بشكل كبير وواضح وبنّاء في القضاء على الآراء 
الشاذة، وعلى إزالة أسباب التطرف، كما سيؤدى إلى تحقيق جانب كبير مــن التـــارب بيــن العلماء، ويزيـل كثيرًا مـن أسبـاب الفــقــة والخـلاف، مما يسهم - وبلا شك - في وحدة صف الأمة، ولاسيما في مواجهة الأفكار الشاذة والمنحرفة والضالة والمتطرفة.

سادساً: الحذر من مفارقة الجماعة والشذوذ: فمما لا شك فيه أن الشذوذ بالر أي ومخالفة ما عليه الأمة من الوسائل الخطيرة التي كانت لها السبب الأكبر في انتشار فكر التكفير، كما أن اجتناب المفارقة يعد معصمًا من معاصم النجاة من الفتن بإذن الله، فمن مخارج الفتن في كل زمان

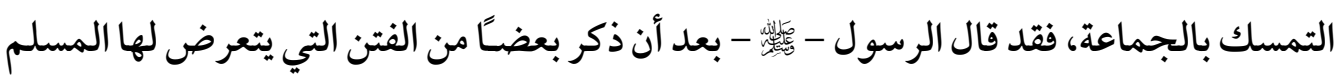

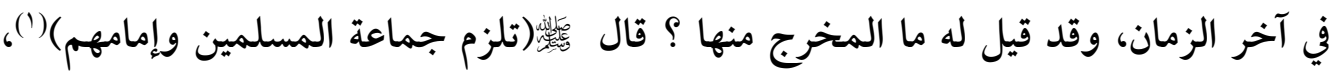
فالتمسك بالجماعة يحصل به الهدي إلى الصراط المستقيم، والنجاة من الفتن ويؤمن به من الانحر اف إلى طرق أهل الضلال.

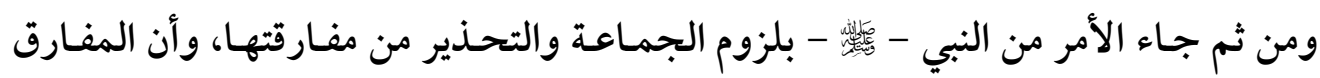
لجماعة المسلمين على خطر عظيم، وإذا مات على مفارقته هذه مات كميتة أهل الجاهلية، قال

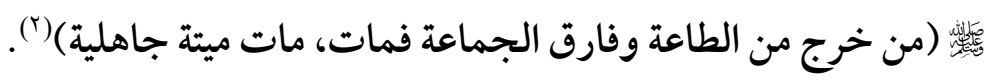
فعلى المسـلم أن يلـزم جمـاعـة المسلـمين ولا يفارقهـا ولا يشـذ عنها في الاعتقاد أو الأقوال أو الأعمال، حتى يسلم من الفتن الظاهرة والباطنة، وقد حرص أئمتنا الكبار على لزوم الجماعة وعدم الاسـتقلال بالر أي في مسـائل كثيرة، لأنهم يرون أن مخالفة إجماع الأمة وما كانو اعليه ليس بالأمر الســـل، وهو من أكبر الأسـباب المؤدية للانحر اف، وذلك لأن التفرد مظنة الخطأ (1) أخرجه الإمام البخاري في صسحيحه، كتاب: الفتن، باب: كيف الأمر إذا لم تكن جماعة، حديث رقم .$v \cdot \Lambda \varepsilon$ (ץ) أخرجه الإمام مسـلم في صسحيحه، كتاب: المغازي، أبواب الإمارة، باب: من خرج من الطاعة وفارق

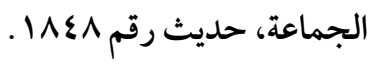




\section{المجلد السابع والثلاثون إصدار ديسمبر 19.}

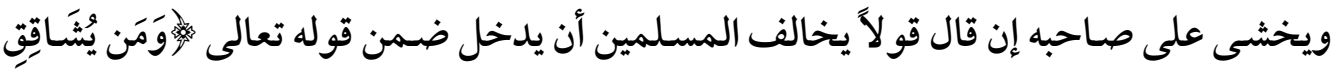

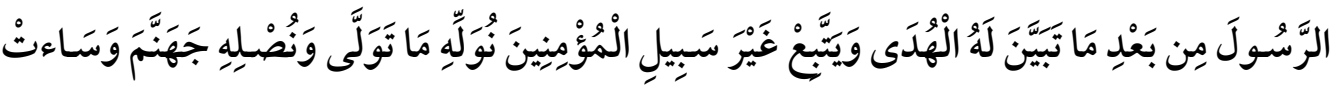
مَصِيراً (النسـاء: آية 11 (1)، فمن رغب عنها فقد فارق الجماعة وخلع ربقة الإسـلام من عنقه،

$$
\text { وشذ عنهم واتبع غير سبيل المؤمنين. }
$$

سابغا: تصدى الأزهر لهذا الفكر الضال: حتى يكون للأزهر دور فعّال ومؤثر في هذه القضية . وغيرها من القضايا الأخرى، يجب أن نعمل جادين على إعادة الاعتبار لمنارة الإسلام وحصن الشريعة وبيت الوسطية (الأزهر الشريف)، وتوفير الدعم اللازم لاستقلاله المالي والإداري، مع كفّ أيدي أصحاب الأفكار المخالفة له عن العبث به أو بمناهجه الوسطية الراسخة عبر القرون في قلوب الناس، وإخراج الأزهر ومؤسساته من معترك التنافس السياسي، ليكون رأيه مستقلاً خالصًا من علائق دنيا السياسة، وناصحًا وموجهًا لله - تعالى - ولمصلحة الوطن. عندئذٍ يتصدّى الأزهر الشريف بشكل جاد ومعلن لهذا الفكر الضالّ من خلال دراسات شرعية قوية الاستدلال، راسخة القدم في التحقيق الفقهي، وأن يُجاهِر علماؤه برفضهـم لهذا الانحر اف هُ الفكري، ويقوموا بدورهم الدعوي في توعية الناس من مخاطر ظاهرة التكفير، وأنها لا تنتمي للإسـلام ولا لمنهجه الوسطي من قريب أو بعيد، ثم يتناولون الشـبهات التي يُضـل بها قادة هذا الفكر التكفيري فلذات أكبادنا لينتزعوا منهم انتماءهم، ويحولوهم إلى قنابل موقوتة تنفجر هنا وهناك، ثم تُنَََر هذه الدراسات وتُدرَّس في المدارس والجامعات والمساجد ووسائل الإعلام، وتُناقش عبر ندوات حوارية بحضــور الرموز الدينية لهذا الفكر الضــالّ، ومشــار كتهم ليظهر الصــحيح من السـقيم، ويرجع الصـادق منهم إلى الحق، ويُفحَم صــاحب الهوى على الملأ ويعرف أنه ضال مضل.

وهكذا دائمًا كان دور الأزهر الثــريف - وما زال - على مر العصـــور وفي كل زمان وفي كل اتجاه وفي كل الأحوال يعمل على التعايش السلمي بمحاربة الأفكار الهدامة والتيارات المتشددة 
والمنحلة، حتى يبقى المجتمع في سلم وسلام، والبلاد والعباد في استقرار وأمان. ثامناً: تفكيك ونقد التراث التكفيري والرد على شبهاته المثارة: فالقارئ لكتاب الله - تعالى يجده حافلاً بالرد والنقض للشبهات التي أثارها المشركون أو اليهود أو المنافقون في مجال العقيدة، وفي ذلك دلالة على أهمية هذا الأمر باعتباره وسيلة ضرورية لعلاج تلك الظاهرة المنحرفة، وهو أسلوب قر آني لا ينبغي تركه في أي عصر، بل الحاجة له قائمة ما دام الصراع بين الحق والباطل قائما، والأمثلة على ذلك من القرآن الكريم أكثر من أن تحصر ('). يضـاف إلى ما سبق اهتمام المؤسسـات التربوية بإبراز دورها في الوقاية من الأفكار التكفيرية، وتتمثل هذه المؤسســات في: الأسـرة والمدرسـة والمسـجد، فعندما تتعاون هذه المؤسســات وتتكامل فيما بينها، في تربية شـباب الأمة على المنهج الوســي الذي هو شـعار هذه الأمة، إذ الانحر اف الفكري ما هو إلا خروج عن الوسطية نحو الإفراط أو التفريط، فإنها ستبني شخصية واعية متزنة لا تنطلي على صاحبها شبهات التكفيريين. نسـأل الله - تعالى - أن يهلدينا جميعًا إلى سـواء السـبيل، وأن يعصـمنا من كل مكروه وسـوء، ربنا تقبل منا إنك أنت السميع العليم.

(1) حماية المجتمع المســلم من الانحر اف الفكري: مجلة البحوث الإســلامية، السـعودية، العدد السـابع

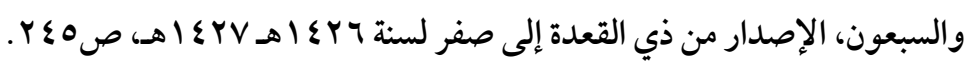


المجلد السابع والثلاثثن إصدار ديسمبر 19.rم م م

गิे

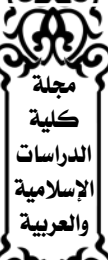

- 255

osec 


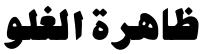

إن دين الإسـلام مشـتق من السـلام وهو دين التسـامح والوسطية، ينبذ العنف والغلو ويرفض التطرف، ويدعو إلى الوسطية والاعتدال، فقد قامت شِـرُعته على جملة من المبادئ والمقاصـد

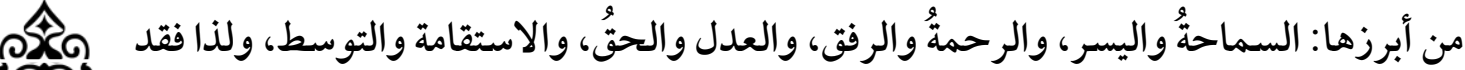

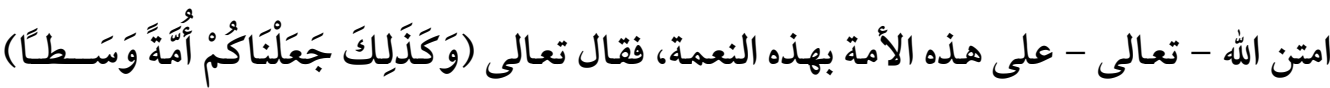

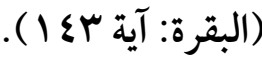

ومع هذه السمة الأساسية التي تميز بها الإسلام عن غيره، إلا أنه قد ظهر في هذه الأمة من جنح إلى الغلو والتطرفـأواتخذ من أعمال العنف والإرهاب وسـيلة للوصسول إلى تحقيق ما يؤمن به من أفكار شاذة، ينسبها إلى الإسلام البريء منها، وما كان لهذه الأفكار الشاذة أن يكون لها قبول بين أوساط الأمة وشبابها لو لا مجموعة من الظروف والأسباب التي وُجدت لتوفر غطاءً مناسبًا لاعتناق بعض المسلمين للأفكار المتطرفة المناقضة للاعتدال والوسطية التي دعا إليها الإسلام

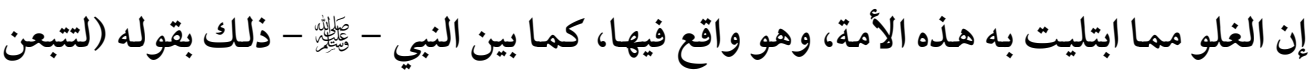
سَنَنَ من قبلكم شبر ا بشبر، وذراعا بذراع، حتى لو سلكوا جُحْرَ ضَبِّ لسلكتموه، قلنا: يا رسول الله، اليهود والنصــارى؟ قال: فمن ؟)(')، فأهل الكتاب قد غلوا، وقد نهاهم الله - عز وجل -

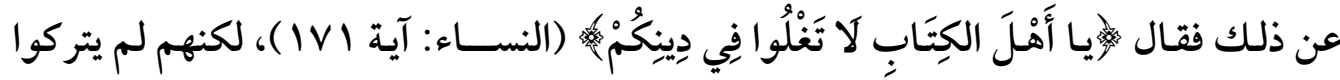
غلوهم، وقد حذا كثير من هذه الأمة حذوهم، حتى صار الغلو سمة كثير من هذه الأمة. وقد تطورت هذه الظاهرة - بعد أن كانت عبارة عن حوادث فردية أو متفرقة محدودة تظهر وسـرعان ما تزولّ إذ لم تكن منتشـرة ذلك الانتشـار الذي نشـاهده في عصـرنا الحاضـر - إلى أن (1) أخرجه الإمام البخاري في صحيحه، كتاب: أحاديث الأنبياء، باب: ما ذكر عن بني إسر ائيل، حديث 0 ـ ؟ـ. 
أصبحت ظاهرة متفشية ومنهجـًا وأسـلويًا له أصوله ومنطقه الذي ينخدع به معتنقوه من شباب الأمة، وصـار يهدد الدين والرسـالة ذاتها في تشـويه صسورتها وهدم مقاصـدها، إذ الغلو يناقض مقصسود الثـارع الحكيم من إرادة الرحمة بالعباد، وتحصيلِ مصـالحهم، ودفع المفاسـد عنهم،

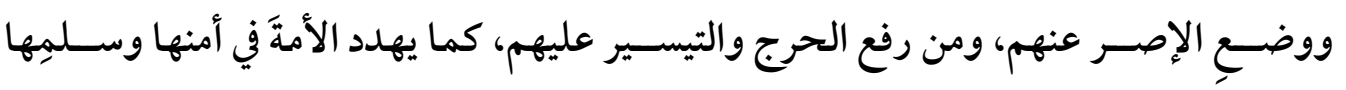
واستقر ارِها وتنميتِها، وهكذا أصبح الغلو يمثل تحديًا حقيقيًا للمجتمعات المعاصرة. وترمي هذه الكتابة - المتواضـعة - إلى تسـليط الضــوء على هذه الظاهرة الخطيرة (ظاهرة الغلو)، وتحليل أســبابها، وبيان علاجها، بعد محاولة تدقيق مفهومها وبيان نشــأتها، وتحذير الشرع منها.

\section{تعريف الغلو:}

إن العلم بحقائق الأشـياء، والوعي بمفاهيمها يُعد مدخلاً أســــــا لتضـيق دائرة الخلاف أو إزالته، إذ ما تكاد أن تجد خلافًا في حكم إلا ومن ورائه اختلاف أو سـوء فهم أو جهل بحقيقة الأمر المختلف فيه، فأحكام الناس على الأثـياء عائدة إلى التصـور، وفي المأثور: الحكم على

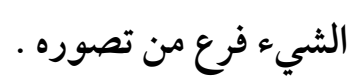

ومن الألفاظ والمصطلحات التي يحتاج إلى فهمها الشرعي ومعناه اللغوي وفهم مر اد الشـارع منها (لفظ الغلو)، إذ لا بد في فهمه من الرجوع إلى معيار ثابت، إذلو ترك هذا اللفظ إلى البثـــ لأصسبح نسبيًا بحسـب اختلاف أهو ائهم ومشــاربهم وانتمائهم، واتباع الهوى يؤدي إلى فسـادٍ واختلافٍ غير متناه، فثبات المعيار الذي ينظر بواسـطته وتفهم الحقائق في ضــوئه أمر لا محيد عنه.

الغلو في اللغل: بالرجوع إلى المصادر والمعاجم اللغوية ظهر لنا أن الأحرف الأصلية لهذه الكلمة ومشتقاتها تدور حول معنى واحد هو: مجاوزة الحد وتعديه. 


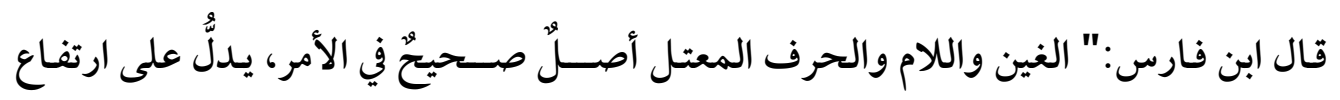

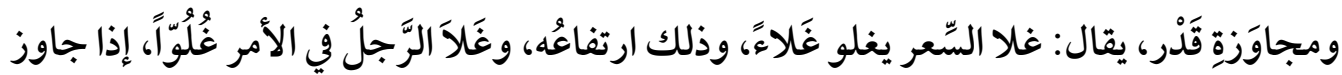
حدَّه، وغلا بسَهْمِه غلواً، إذا رَمى به سَهْمًَا أقصى غايتِه "(1).

وقال الجوهريٌُ:" غلا في الأمر يغلو غلوَّا، أي جاوز فيه الحدّ "(؟)، وفي المصـباح المنير :" غلا

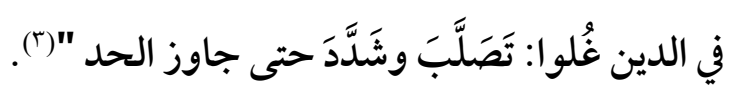

وقال ابن منظور:" وأَصل الغلاء: الارتفاع ومُـــاوزة القَدْرِ فــي كلِّ، وغلا فــي الدِّين والأمر

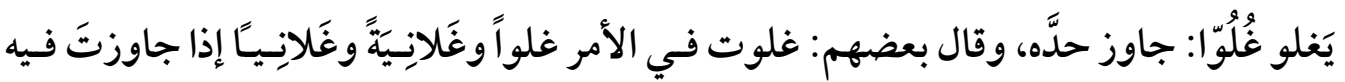

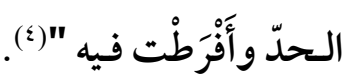

مما سـبق يتبين لنا أن الغلو في سـائر اسـتعمالاته اللغوية يدل على الارتفاع والزيادة ومجاوزة الأصسل الطبيعي أو الحد المعتاد، وعلى ذلك فمادته تدور في اللغة حول مجاوزة الحد أيًا كان نوعه.

وفى الاصطلاح: فقد اجتهد العلماء في وضع تعريف للغلو بعبارة موجزة، وإليكم بعض تلك التعريفات:

قال شـيخ الإســلام ابن تيمية:" الغلو: مجاوزة الحد بأن يزاد الثـيء في حمده أو ذمه على ما

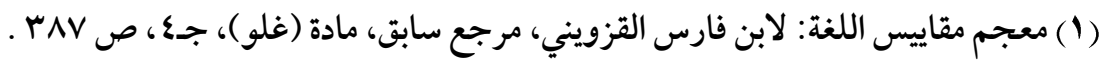

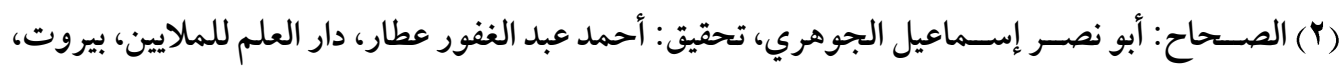

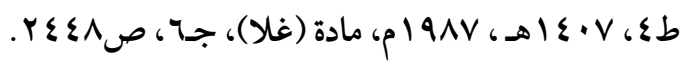

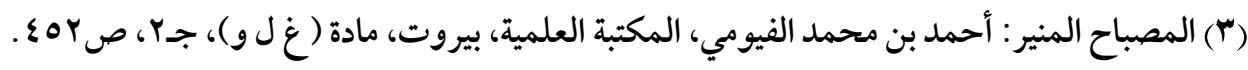

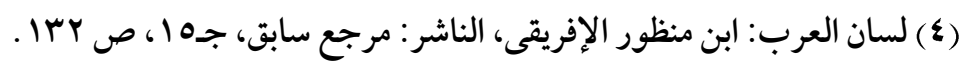


وقال أبو بكر الجصاص:" الغلو في الدين هو مجاوزة حد الحق فيه "(؟).

وعرفه الحافظ ابن حجر بأنه:" المبالغة في الثـيء والثشــديد فيه بتجاوز الحد، وفيه معنى

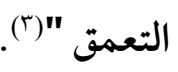

وقيل: هو التثــدد والخروج عن حد الاعتدال في الدين اعتقادًا أو عملاً، أو هما معًا، أو هو مجاوزة الحد المشروع في أمر من الأمور، بأن يُزاد فيه أو يُنقص عن الحالة التي شُرع عليها؛ وقال الإمام أبو شــامة:" فكل من فعل أمرًا موهمًا أنه مشــروع وليس كذلك، فهو غال في دينه مبتدع فيه قائل على الله غير الحق بلسان مقاله أو لسان حاله "(•). 
البدعة، لخروجه عن رسـمم الثـــع من جهة الزيادة والمبالغة، ولا يشـفع له كونه صـادرًا عن اجتهاد وحسن نية، فإن اقتصاداً في اتباع، خير من اجتهاد في ابتداع.

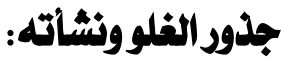

إن ظاهرة الغلو قديمة قدم الرسـالات السـماوية، إذ تمتد جذورها إلى القدم، وهى سـمة في

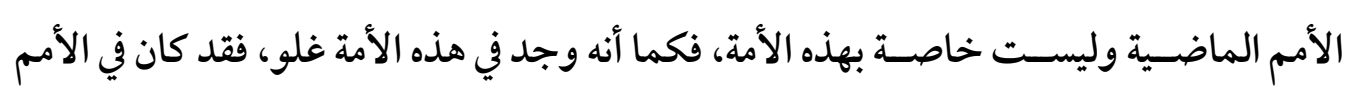

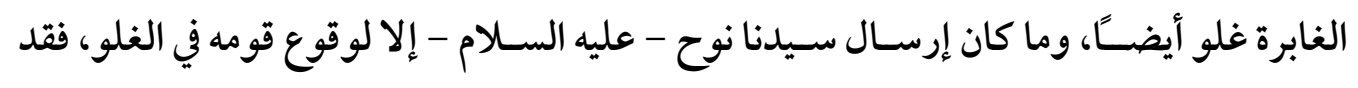

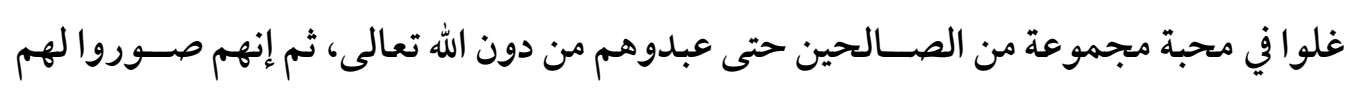

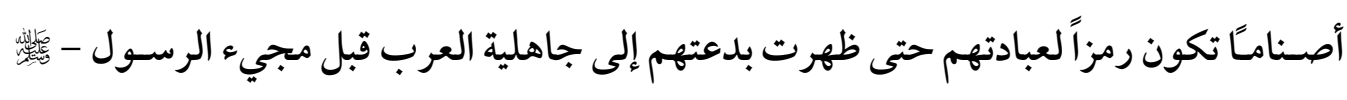

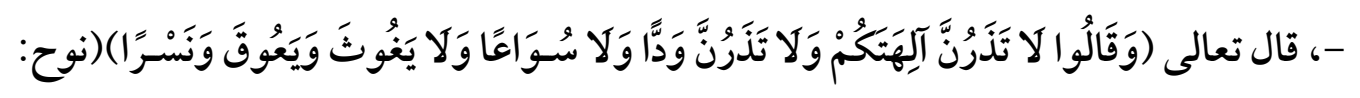

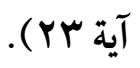
ثم ظهر الغلو في بني إسـرائيل وبلغوا فيه مبلغنَّا كبيراً، وقد قص الله - عز وجل - علينا ما وقع

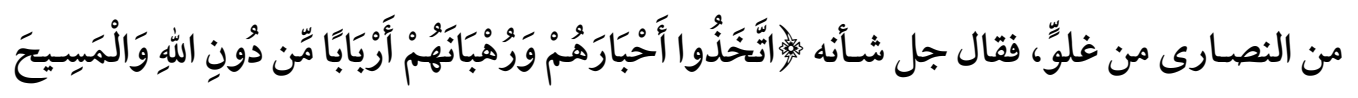

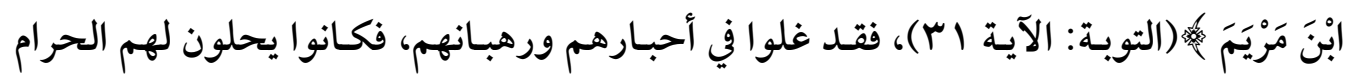
فيحلونه، ويحرمون عليهم الحلال فيحرمونه.

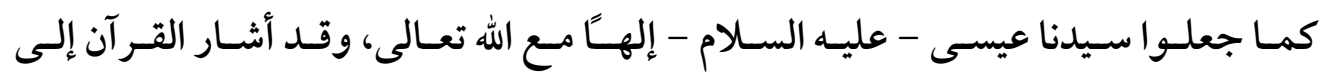

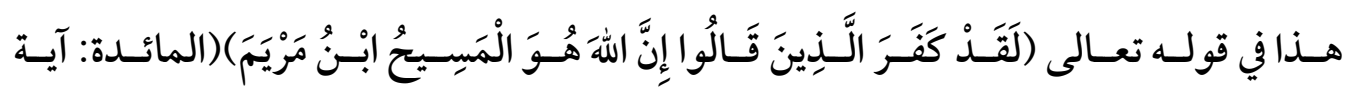

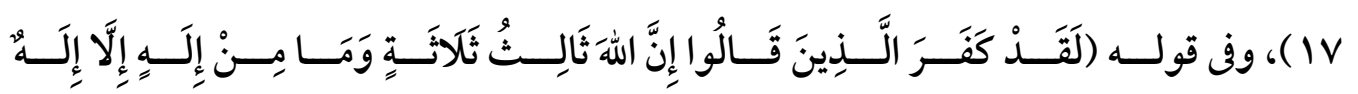

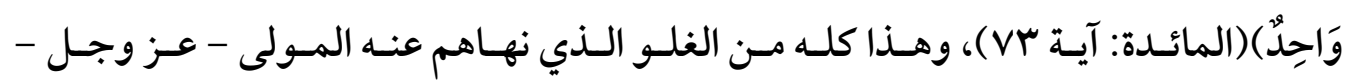

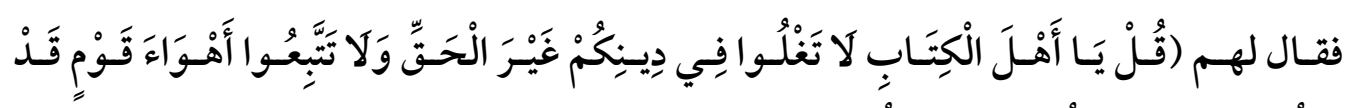

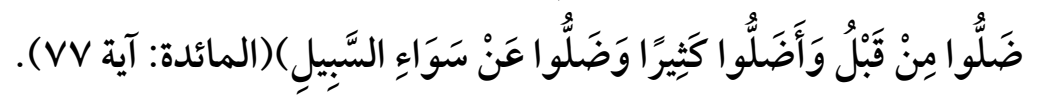




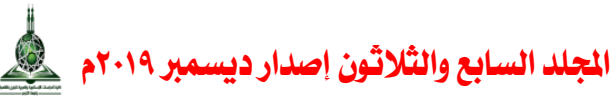

قال الإمام ابن كثير - رحمه الله -:" ينهى - تعالى - أهل الكتاب عن الغلو والإطراء وهذا

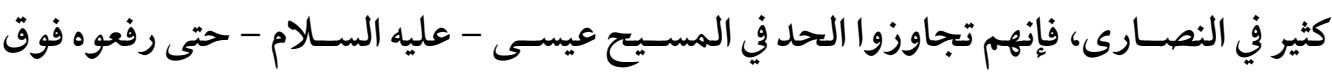

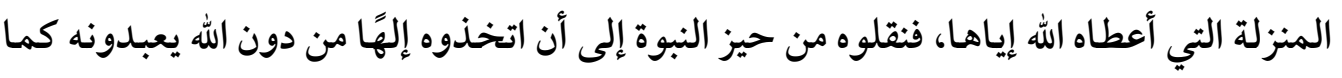

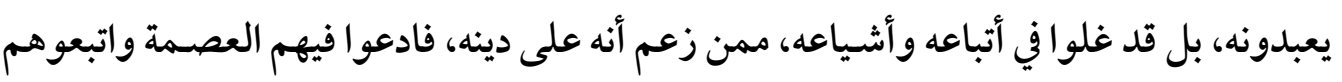

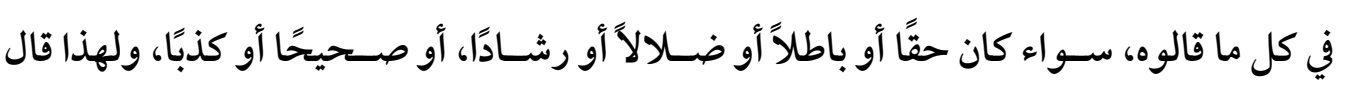

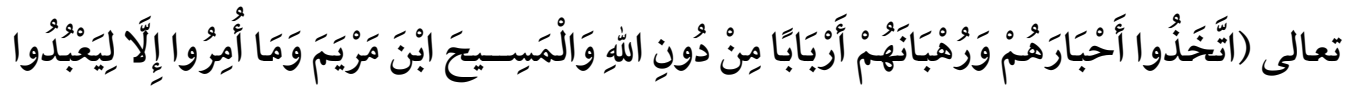

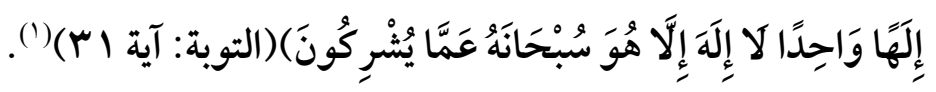
وفى عصـر النبي - ولثد - عاش هو وأصسحابه عاملين بمنهج الوحي على أفضـل وجه وأعدله، وقدموا لنا صسورة مثالية فريدة في تنفيذ منهج الله بتوازنه واعتداله ووسـطيته، وشـموله وواقعيته وكماله، إلا أنه قد وقعت بعض المواقف الفردية المعدودة (() من بعض الصـحابة تشـير إلى الى

(1) تفسير القرآن العظيم: أبو الفداء إسماعيل بن عمر بن كثير تحقيق: سامي بن محمد سلامة، دار طيبة للنشر

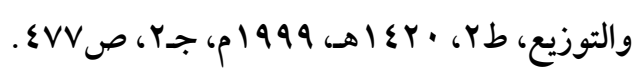

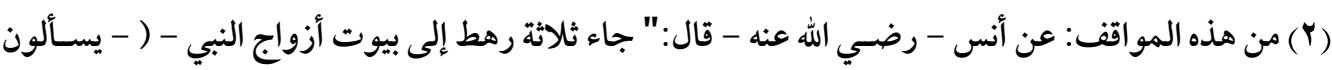

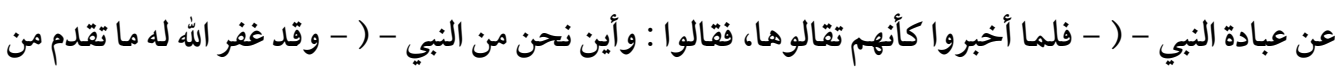

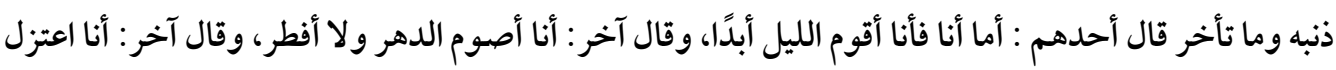

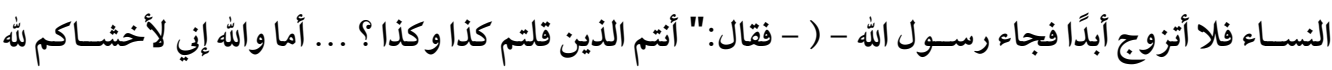

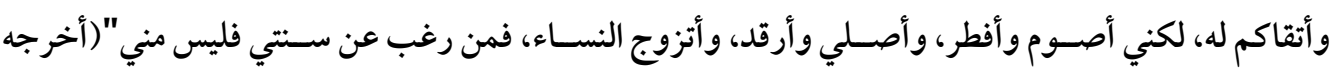

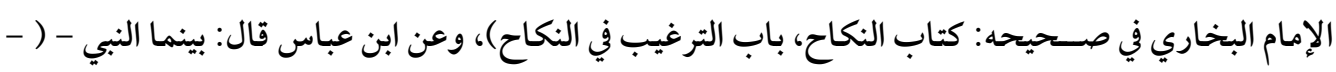

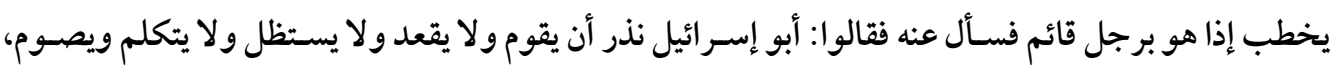

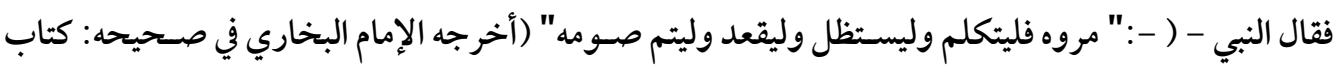

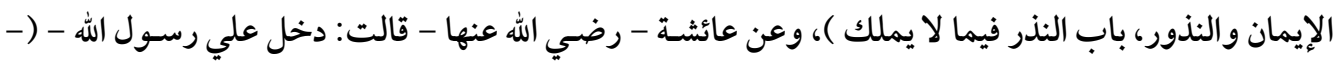

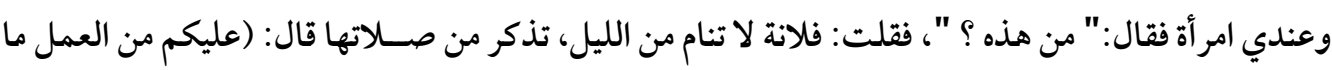


الاتجاه إلى سبيل الغلو والتشدد في الدين عن حرص صادق للازدياد من الخير، لكن الرسول لهاب - كان له بالمرصاد، فاستطاع أن يُفقه أصحابه ويعلمهم ليصححوا ما قد يحصل من بعضهم من غلو - إن جـاز التعبير - فردهم عن هـذا السـبـل، وقوّم هـذا العوج وصــحح نظرتهم، وأرشدهم إلى سبيل الاعتدال، فاستجابو ا وأطاعوا، كل ذلك كان بأسلوب حكيم.

ومع وقوع بعض هذه الحالات الفردية في حياة النبي - - فئس - في الغلو، لكنها لا تذكر لقلتها ولعدم استمر اريتها ولأنها لا تمثل عقيدة أو منهجًا، بل سرعان ما زالت عند معرفة الصواب.

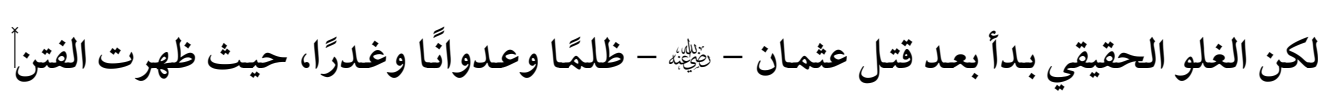
وثارت أعاصير الشبهاتُ وأقبلت الفتن مهرولة يحمل رايتها الغلو والتطرف فُ فكان غلو الخوارج

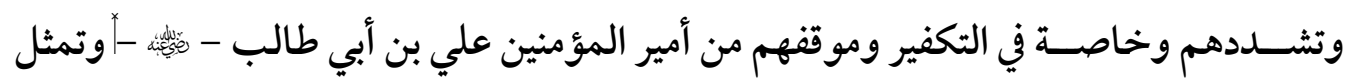
غلوهم في دينهم بعد ذلك من خلال أصــولهم العقدية التي اشــهـرت عنهم بعد هذه المرحلة التأريخيةً حيث تأصلت أصولهمّ وظهرت قواعدهم في عقيدتهم وفي تعاملهم مع المسلمين ('). واسـتمر مسـلسل الغلو في تاريخ الأمة، فلم يسـلم عصـر من العصـور من وجود فِرق من فرق الغلاة، ولم يكن عصـرنا بمنأى عن هذه الظاهرة، فقد ظهرت مظاهر عدة من مظاهر الغلو، وإن ما نشــهده مما اكتوت به هذه البلاد من أحداثٍ وتفجيرات وعنف وتكفير، كل هذا من مظاهر الغلو التي حذرنا منها الإسلام، وحذرتنا منها نصوص الوحيين. ونحن لا ننكر حصــول الغلو في هذه الأمة أيضًـــا كما هو حال الفرق المخالفة من هذه الأمة، ولكن العجيب والغريـب أن نقصـر تهمة الغلو والتطرف على المســلمين فقط، مع أنها من من مده

تطيقون، فو الله لا يمل الله حتى تملوا"، و كان أحب الدين إليه ما دوام عليه صاحبه" (أخرجه الإمام البخاري في صحيحه: كتاب التهجد، باب ما يكره من التشديد في العبادة ).

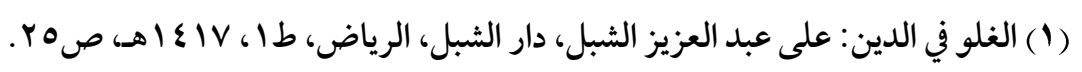


أخلاقيات غيرهم من اليهود والنصارى ومن سار على دربهم واحتذى حذوهم.

فالغلو ليس خاصّتًَا بالمسـلمين وحدهم دون سـواهم، بل هو منهج له أسـبابه وعو امله| التي لا ينفك عنها أي مجتمع بشرى، لأن من أعظم أسبابه الجهل (ليس المر اد بالجهل هنا الأمية ولكن المر ادبه هنا هو نقص التصور الصحيح الكامل للمسألة التي غلا فيها من غلا ) والذي لا يخلو منه مجتمع أبـداً، وإلا فأي مجتمع يمكن أن يقال إن جميع أفر اده على درجة واحدة في كمال التصور الصحيح لجميع الأمور، حتى يمكن أن ينجو جميع أفر اده من الغلو? هذا المجتمع لم ولن يوجد، فهذا أكمل مجتمع بشـري عرفته البشـرّيةٌوهو مجتمع سـيد ولد

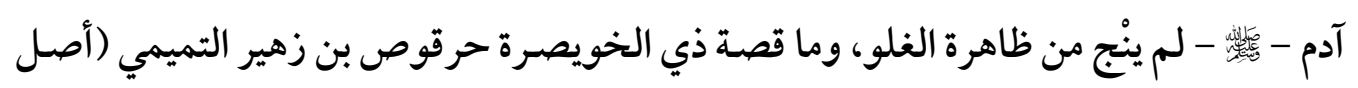

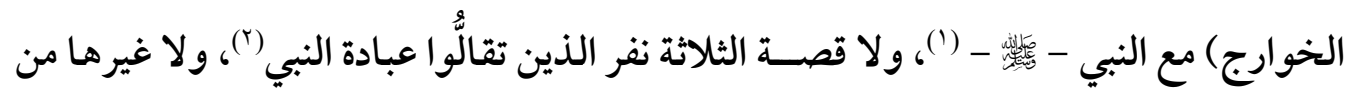

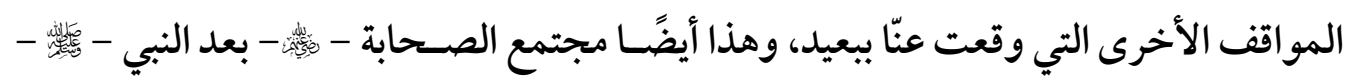

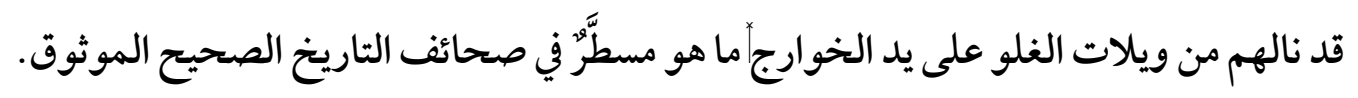

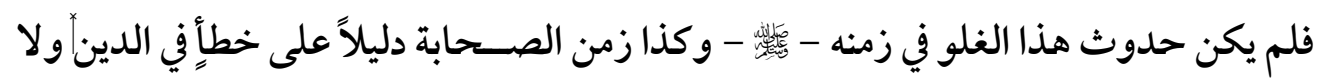

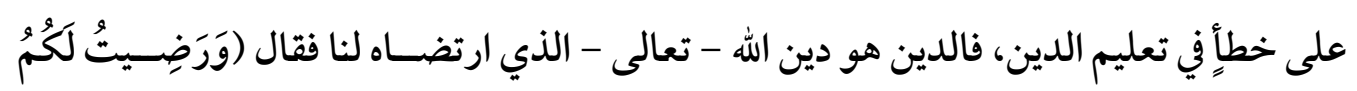

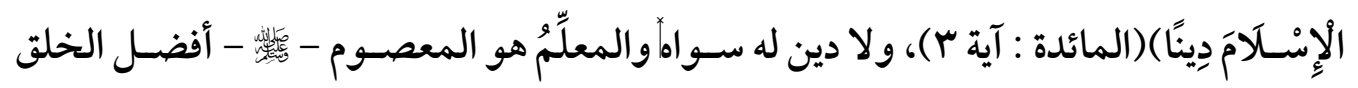
على الإطلاق المبعوث رحمة للعالم. إذن فالغلو ليس دائمًا دليالً على خطأ المذهـب أو الدينَّ وإلا لكانت كل الأديان والمذاهب باطلةً لعدم وجود مذهب أو دين - كما سـبق بيانه - إلا وفي أتباعه غلاة متطرفون، ولذلك فإنه

(1) أخرجه الإمام البخاري في صسحيحه، كتاب: اسـتتابة المرتدين والمعاندين وقتالهم، باب من ترك قتال

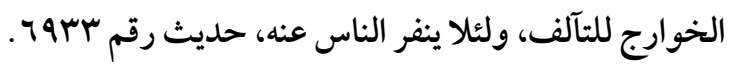

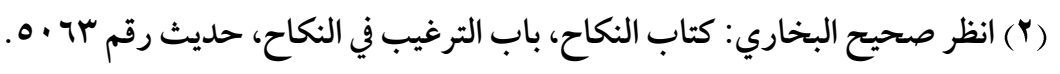


من الغلو والتطرف أيضًا أن نلغي مذهبًا أو منهجًا مأَ لمجرد وجود من غلا وتطرف فيه ('). ولا يعني هذا أننا نقف مكتوفي الأيدي أمام ظاهرة الغلوأكلا إذ ما هذا البحث إلا محاولة ووجه من وجوه إطلاق اليد في محاولة الإصـلاح ومقاومة الغلو، ولكن هذا يعني أننا يجب أن نجابه من يهاجم دينتا وشـريعته بالغلوألمجرد وجود غلاة فيه بأن غلو الغالين لا يدل على غلو ديننا، كما لا يدل على أن الغلو ليس خاصـًا بالدين الإسـلامي وحده، وإنما هو موجود عند جميع من

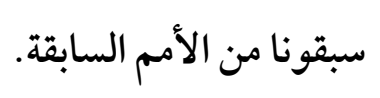

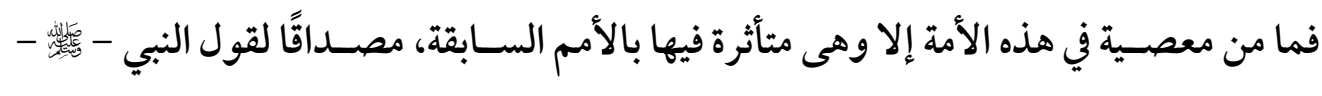
(لتبعن سنن من قبلكم شبر ا بشبر، وذراعا بذراع، حتى لو سلكوا جحر ضب لسلكتموه، قلنا: يا رسول الله، اليهود والنصارى؟ قال: فمن؟ )(؟).

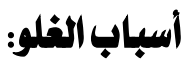

لقد جعل الله لكل شـيء سـبًِا، وجعل الظواهر والمشـكلات الني يقع فيها الناس راجعة إلى أسباب دافعة إليها، وهذه سنة من سنن الله - عز وجل - في الخلق والكون، وظاهرة الغلو ليست بدعَّا من المشـكلات، إذ لها أســباب وعوامل أدت إلى الوقوع فيها، وليس المر اد هنا حصـر الأسباب التي أدت إلى الغلو، إذ الإحاطة الشـاملة بجميع الأسباب غير ممكنة، لأن طرق الشـر والانحر اف غير منحصرة في الأصل. قال أبو بكر الطرطوشي - رحمه الله -:" والخطأ لا تنحصر سبله، ولا تتحصل طرقه، فاخطُ كيف شـئت، وإنما الذي تنحصـر مدار كه وتنضـبط مآخذه فهو الحق، لأنه أمر واحد مقصـود

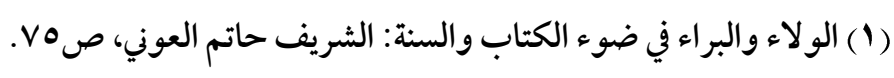

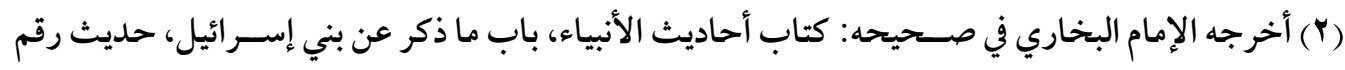




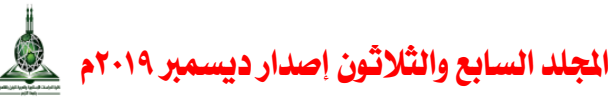

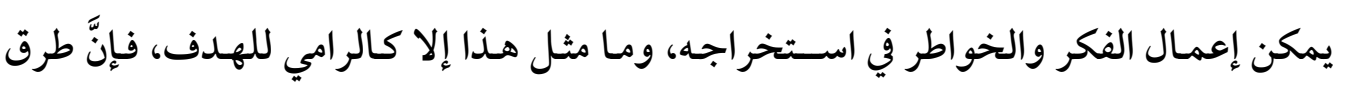

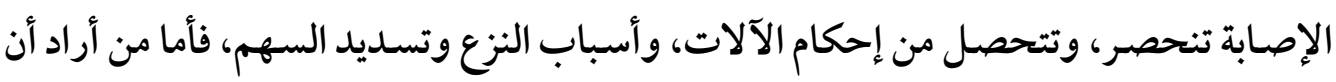
يخطئ الهدف فجهات الأخطاء لا تنحصر ولا تنضبط إلا أن نذكر من ذلك حسب الإمكان" ('). ويكاد يجمع الباحثون - في ظاهرة الغلو - أن أسبابه لا تنحصر في شيء بعينه، وإنما منها ما هو

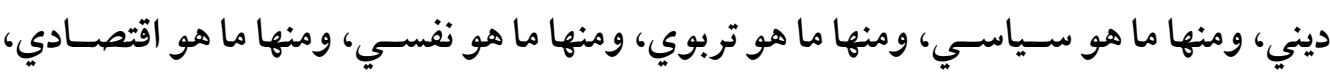

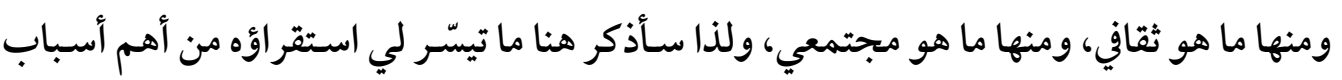
ظهور الغلو بين المسلمين، وهي أسباب غالبًا ما تكون ممهدة لظهور الغلو في أي زمان أو بيئة. اــ عدم فهم الإسلام على حقيقته: فكثير ممن يصاب بهذا الداء لا يعرف الكثير عن الإسلام تمام المعرفة، فإن من عرف الإسلام ومزاياه وخصائصه وسماته، وأنه دين الوسطية والاعتدال، وطبَّق

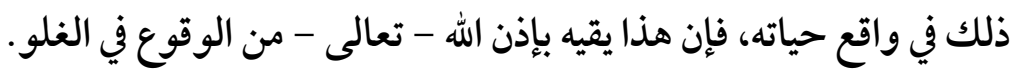
لكن الجهل سـبب لكل داء، وهو رأس كل بلية، وهو يشـمل الجهل بالكتاب والسـنة وبمنهج

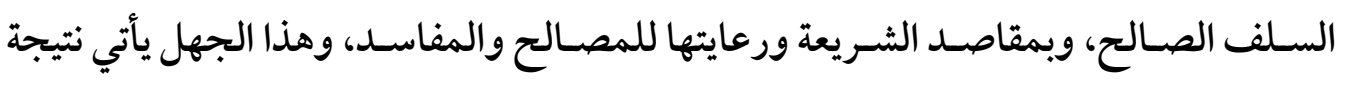
غياب الوعي الديني وعدم الفهم الصسحيح والعميق لنصـوصـه، فإن من عنده علم بالكتاب والسنة، وما دلا عليه لا يتصور وقوعه في الغلو والتطرف. وهو من أهم أسـباب غلو الخوارج، وفي الحديث أن النبي - - أبك - قال عنهم (قوم يقرؤون

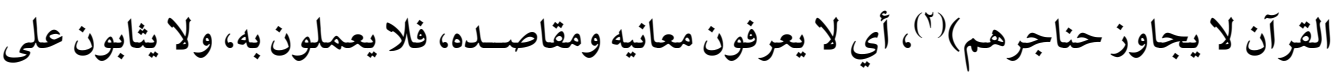
قراءته، فهذه القراءة لا يرفعها الله ولا يقبلها، فكأنها لم تتجاوز حلوقهم، وهذا المعنى أشار إليه (1) الحوادث والبدع: أبو بكر الطرطوشى، تعليق: على حسـن الحلبى الأثرى، دار ابن الجوزى، السعودية، ط (ז') أخرجه الإمام البخاري في صسحيحه، كتاب: أحاديث الأنبياء، باب: قول الله تعالى (وإلى عاد أخاهم هودا

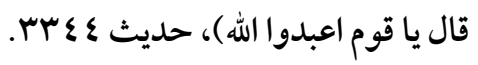


الإمـام النووي فقـال:" المر اد أنهم ليس لهم فيـه حظ إلا مروره على لســـانهم لا يصــل إلى حلوقهم، فضلاً عن أن يصل إلى قلوبهم، لأن المطلوب تعقله وتدبره بوقوعه في القلب "(1). وليس المقصود بالجهل هنا الجهل المطلق بالدين، فهذا لا يؤدى إلى الغلو والتطرف، بل إلى نقيضه وهو الانحلال والتسيب، وإنما المراد به: نصف العلم، الذي يظن صاحبه به أنه دخل في زمرة العالِمين، وهو يجهل الكثير والكثير، فجهله هذا يؤدي به إلى الغلو، ومع ذلك يظن نفسـهـ من أهل العلم والاجتهاد، وهو لم يبلغ تلك الدرجة، فإن العلم بظواهر النصوص الثـرعية دون عللها ومقاصدها لا يكفي لبلوغ درجة الاجتهاد.

ورحم الله الإمام أبا إســحاق الثــاطبي، فقد نبه على هذه الحقيقة بوضـوح، حين جعل أول أسباب الابتداع والاختلاف المذموم المؤدي إلى تفرق الأمة شيعًا: أن يَعتقد الإنسان في نفسه أو يُعتقد فيه - أنه من أهـل العلم والاجتهاد في الدين، وهو لم يبلغ تلك الدرجة، فيعمل على ذلك ويعد رأيه رأيًا، وخلافه خلافتًا، فنراه آخذاً ببعض جزئيات الثـريعة في هدم كلياتها، حتى ني يصسير منها ما ظهر له بادي رأيه من غير إحاطة بمعانيها، ولا رسوخ في فهم مقاصـدها، وهذا هو

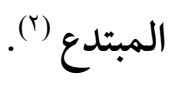
فالجهل بالدين وقلة البصيرة وعدم الفقه فيه يؤدى إما إلى فهم زائد عن الواجب وهو الإفراط، أو عكسـه وهو التفريط فيه، وكل هذا خروج عن منهج الاعتدال، وهذا هو الغلو بعينه، فالغلاة

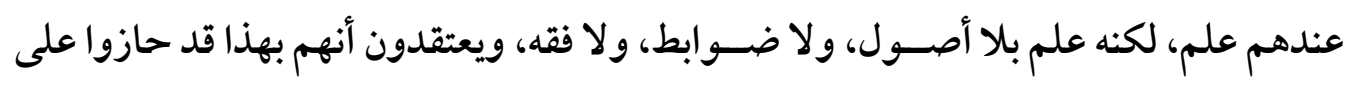
علم الأولين والآخرين، وهكذا كان حال الخوارج، يدعون العلم والاجتهاد، وهم من أجهل

(1) فتح الباري شـرح صسحيح البخاري: لابن حجر العسقلاني، تحقيق: محمد فؤاد عبد الباقي، ومحب الدين

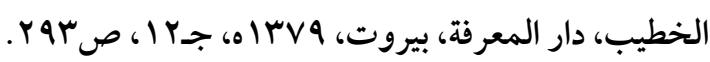
(ז) الاعتصـام: إبر اهيم بن موسى الثهير بالشـاطبي، تحقيق: سليم بن عيد الهلالي، دار ابن عفان، السعودية،

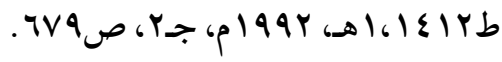


الناس.

rـ التعصب الأعمى: يقوم التعصب على تحيز الشخص إلى طائفة أو مذهب أو قوم أو فكر، فيدفعه ذلك إلى الاعتقاد بأن ما يحمله أو يتتمي إليه هو الصواب الذي لا يحتمل الخطأ، وماعداه

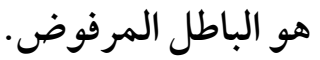

وهذا التعصب من دلائل الإعجاب بالنفس، واتباع الهوى، وهما من أشد المهلكات خطرًا، إذ إذ إنها المتعصـب أشـبه بامرئ يعيش وحده في بيت من المرايا، فلا يرى فيها غير شـخصـه أينما ذهب

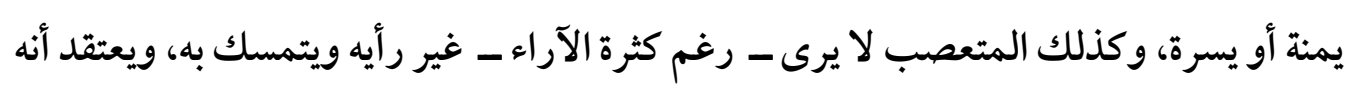
صحيح لا يحتمل الخطأ، بينما يرى رأي غيره خطأ لا يحتمل الصحة، وبالتالي فإنه يرفض آراء آراء

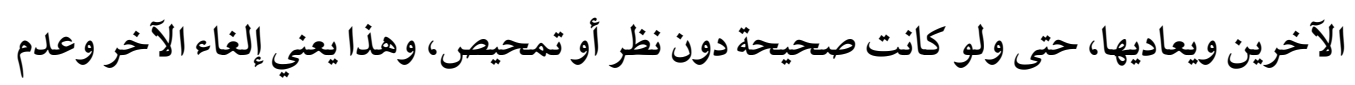

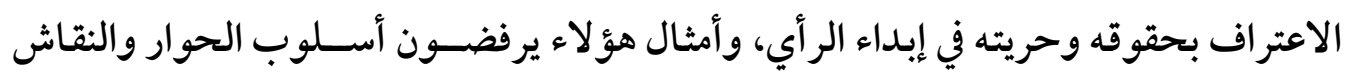

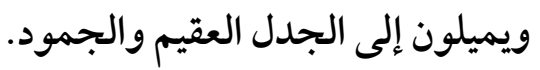

ولذا فقد حذر الإسلام من هذا التعصب ونهى عنه، بل وحاربه بجميع أشكاله وصوره، لما له

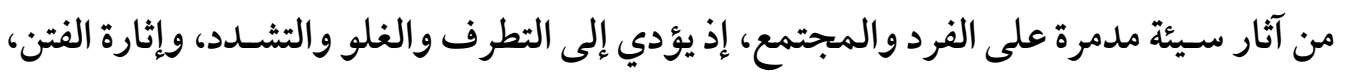
وغرس مشاعر الحقد والكر اهية، وسفك الدماء بين الناس، ومنع الآخرين من ممارسة حقوقة الثهم

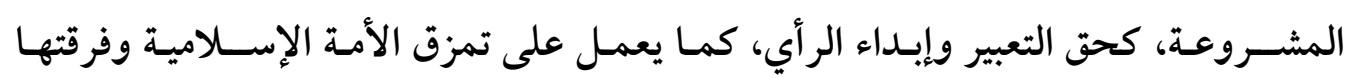

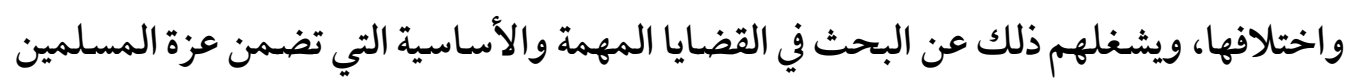
وكرامتهم .

ץ.الفراغالروحي الدي يعيط بالشباب: إن الفراغ الروحي هو ذلك الوضع الذي تكون فيه النفوس

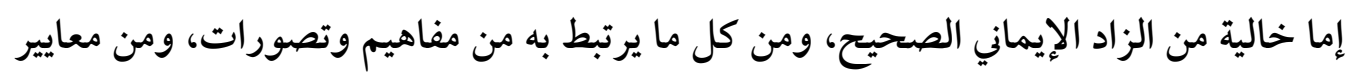

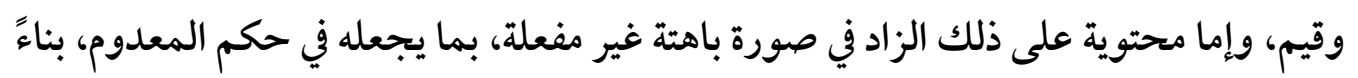


على أن الزاد الإيماني يكتسب مصداقيته من فاعليته وترجمته إلى سلوك في الواقع يعود على الفرد والمجتمع بالسعادة والطمأنينة.

وليس أشـــد على الأمة من الفراغ الروحي الذي ينهك طاقاتها ويبدد قدرات أفرادها، وفي مقدمتهم الثـباب، لأنهم يمثلون الجانب الأكثر التصـاقًا بالواقع، وعلى عاتقهم تقع مسؤولية التغيير والبنـاء، فهم أداة التحول التنموي والاجتمـاعي بكل مـا تعنيـه هـذه الكلمـة من معنى، وعندما يصيب الفراغ الشباب فإن ذلك ينذر ببدء تخلخل العمد الأساسية في بناء المجتمع . وتُعدّ حالة الفراغ الروحي الذي يعيثـهـ قطاع كبير من الثـباب اليوم، ظاهرة خطيرة جدًّا، إذ عدم وجود ما يشبع هذا الفراغ لدى الشباب خاصة إذا وافق ذلك بطالة وعدم وجود سبل الرزق وكسـب العيش، كفيل في ضسياعهم وربما انحر افهم مما يسـهل توجيهـم واسـتغلالهم من قبل الغلاة والمتطرفين، وحسب رغبتهم وخططهم، وربما كان هذا الفراغ سـببا للجريمة والإفسـاد في المجتمع كما هو ملاحظ في هذه الأيام. فتفريغ الشــباب من الإيمان وآثاره الإيجابية يدفعه إلى البحث عن الإشـباع الروحي بطرق مختلفة، وقد تكون متطرفة إلى حد ما، مما يجعله يميل إلى الغلو والتطرّف، وهو يعتقد أنه بغلوه وتطر فه هذا يكون في أعلى مر اتب الإيمان، وهنا لا نحصل إلا على شباب متطرف مغالٍ، وهذا بسبب الفراغ الروحي الذي يعيشه.

ك اتباع المتشابهات وترك المحكمات: وأعني بالمتشابه: ما يشتبه معناه على الكثير من الناس، ولا يدر كه إلا أهل العلم والراسخون في ذلك، والمحكم: هو البين المعنى الواضح الدلالة الذي لا يخفى على أحد.

ولخطورة اتباع المتثــابه وترك المحكم من النصــوص في إفســاد دين من يفعل ذلك، وغلوه

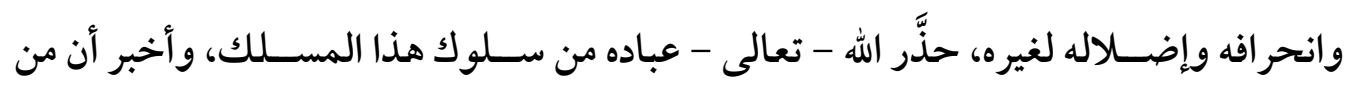




\section{المجلد السابع والثلاثثن إصدار ديسمبر 19.0.}

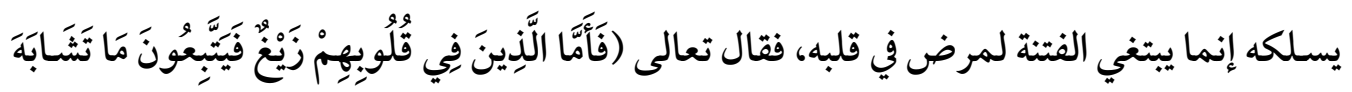

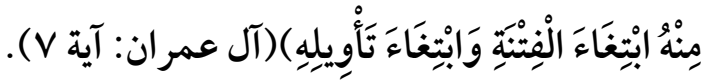

وهذا الذي جعل جماعة الخوارج قديمًا تسـطط في ورطة التكفير لمن عداهم من المسـلمين،

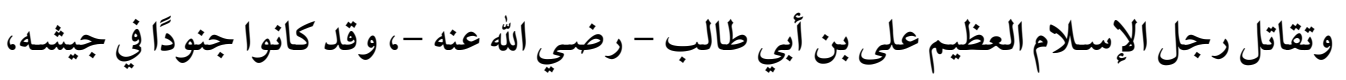
مستندين إلى أفهام عجيبة، بل أوهام غريبة، في دين الله تعالى.

مـ البعد عن العلماء وترك التلقي عنهم: وهذا منذر بخطر عظيم، فإن العلماء هم ورثة الأنبياء، وهم منابر النور، وهم مصدر تلقي العلم الصحيح، وهم أهل الذكر الذين أمرنا الله تعالى بسؤ الهم

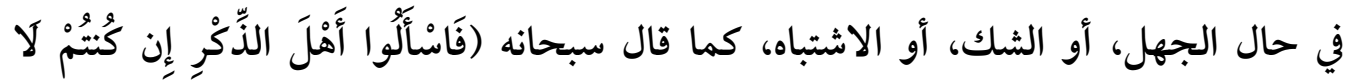

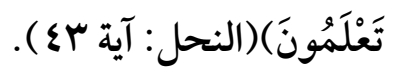

فالإعر اض عن العلماء والبعد عنهم، وجفوتهم وترك التلتي عنهم والاقتداء بهم، والتلقي عن دعاة السوء والفتنة والالتفاف حولهم من أهم أسباب الغلو . وإذا بحثنا عن مصـادر التلقي عند هؤ لاء الغلاة وجدناها مصسـادر تو افق أهواءهم، إما كتب محدثة لخدمة هذه الطائفة من الناس غير موثقة، وإما ما يكتب في بعض الصسحف والمجلات

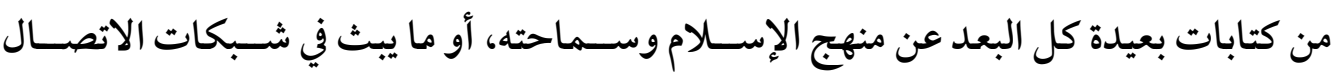
والقنوات الفضـائية من بعض الفتاوى، التي تدعو للتعصـب والبدع تحت غطاء الثدين، فهذه

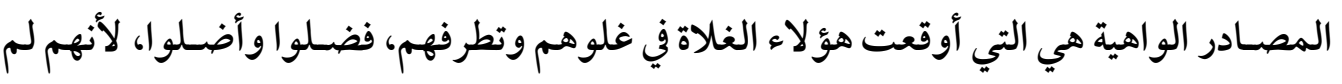
يتلقوا العلم من أهله وشيوخه وخاصته.

1ـ التعالي والشعور بالكمال: وهو داء يدب إلى أذهان البعض من الشباب خاصة، حتى يظن

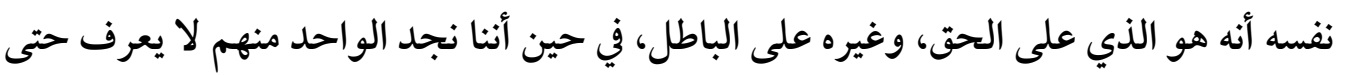

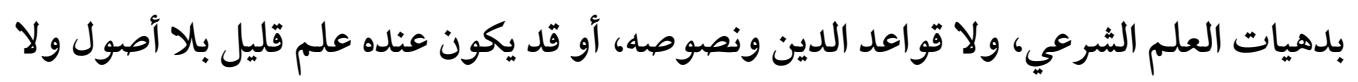


ضوابط ولا فقه ولا رأي سديد، ويظن أنه بعلمه القليل وفهمه السقيم قد حاز علوم الأولين والآخرين، فيستقل بغروره عن العلماء، وينأى بنفسه عن مواصلة طلب العلم، ويحاول أن يسعى إلى الإصلاح والتغيير وفق أوهام رسخت بذهنه، لا أساس لها من سنن الله في خلقه، ولا من

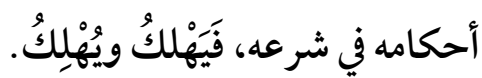

وهكذا كان حال الغلاة الأولون من الخوارج يدَّعون العلم والاجتهاد ويشـعرون بالكمال، بل ويتطاولون على العلماء، وهم من أجهل الناس.

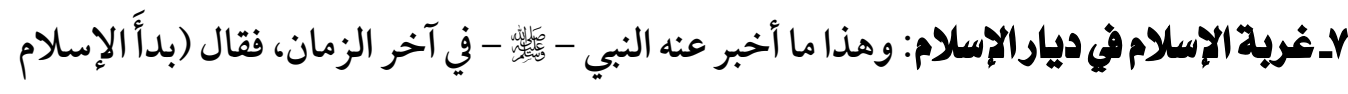

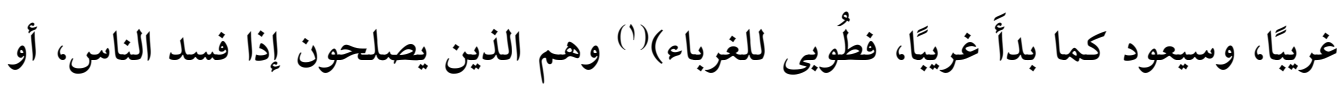
يصلحون ما أفسد الناس، ونحن نعيش في عصر اشتدت فيه غربة الإسلام، فالقابض على دينه كالقابض على الجمر، ولا شك أن غربة الإسلام في ديار الإسلام تؤذن بغياب الوسطية في المجتمعات المسلمة، ومتى غابت الوسطية ظهر الغلو والتطرف، وظهرت البدع والخرافات، وكثر الانحر اف العقدي والفكري، وفسدت الأخلاق.

وقد وصـف الله - سـبحانه وتعالى - هذه الأمة بأنها أمة وسط، والوسط هو العدل والخيار،

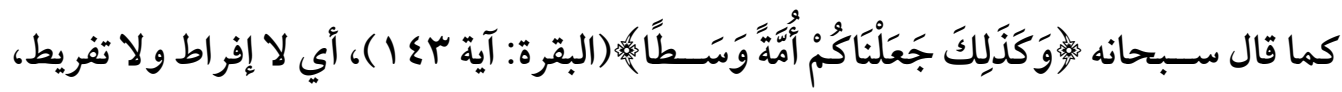
فمن زاد على الدين ما ليس منه فقد غلا وأفرط فيه، ومن لم يقم بحقه كما يجب ونقص منه فقد فرط فيه، فالخير كل الخير في التوسط والاعتدال، وهو منهج السلف الصالح من هذه الأمة. هذه أهم الأســباب التي تجتمع معًا لتقف وراء ظاهرة الغلو، تلك الظاهرة المعقدة التي لها أبعاد نفسية ودينية وسياسية واقتصادية واجتماعية، وإذا ما عملت هذه الأسباب عملها، أنتجت

(1) أخرجه الإمام مسـلم في صسحيحه، كتاب: الإيمان، باب: بيان أن الإسـلام بدأ غريبًا وسـيعود غريبًا، حديث

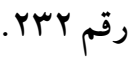


عضوًا فاسدًا في المجتمع لا ينفع نفسه ولا غيره بشيء، وإنما عضو فاسد مفسد، تجب مقاومته

وأخيرًا أود أن أنبه على أن دراسـة هذه الأسـباب يجب ألا تتجه إلى أن تكون تبريرًا للغلو، وإيجادًا للعذر عند الغلاة، إذ هذا المنهج التبريري لا يولد في المآل إلا مزيدًا من الغلو، ويجعل الغالي يسـقط غلوه وجرمه على الناس، وإنما أردت من دراســها وذكرها تشــخيص الواقع، لتكون المعالجة على أصل قوي.

مما لا شــك فيه أن الخوارج بلغوا مبلغًا عظيمًا في الطاعة والعبادة، فقد كانوا حريصـين كل الخوارج والغلو: الحرص على التمسك بالدين، وتطبيق أحكامه، والابتعاد عن جميع ما نهى عنه الإسلام، وكان لهم اشـتغالهم الدائم بقر اءة القر آن قد لا يدر كه الكثير من غيرهم، حتى أصسبح ذلك سِـمَة بارزة

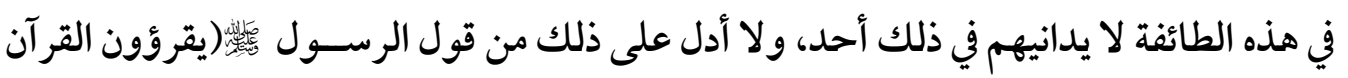
ليس قراءتكم إلى قر اءتهم بشيء، ولا صلاتكم إلى صلاتهم بشيء، ولا صيامكم إلى صيامهم بشـيء) (') ويصـفهم جندب الأزدي بقوله :" لما فارقت الخوارج عليًا، خرج في طلبهم فانتهينا إلى عسـكرهم، فإذا لهم دوي كدوى النحل من قراءة القرآن، وإذا فيهم أصسحاب البرانس أي الذين كانوا معروفين بالزهد والعبادة "(r).

كما اشـتهروا بالصـدق والنفرة عن الكذب، لأنهم يعتبرونه من صـفات الجبناء الذي لا مكان لهم عندهم، قال أبو العباس المبرد:" والخوارج في جميع أصــافها تبر أ من الكاذب، ومن ذي

(1) أخرجه الإمام مسلم في صحيحه، أبواب الجمعة، باب: باب إعطاء المؤلفة قلوبهم على الإسلام وتصبر من

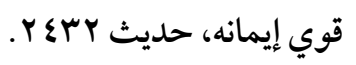

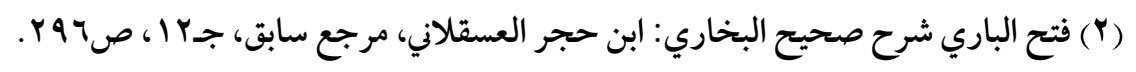


المعصية الظاهرة "(")، ووصفهم ابن تيمية بأنهم " ليسوا ممن يتعمد الكذب بل هم معروفون بالصدق حتى يقال إن حديثهم من أصح الحديث "(().

ومع أنهم كانو ا أهل صسيام وصـلاة وتلاوة للقر آن وصـدق في الحديث، لكنهم تجاوزوا حد

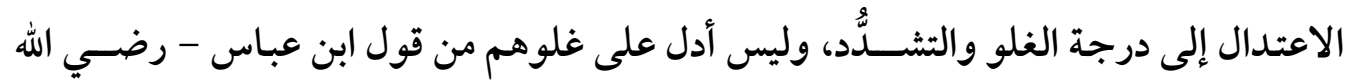

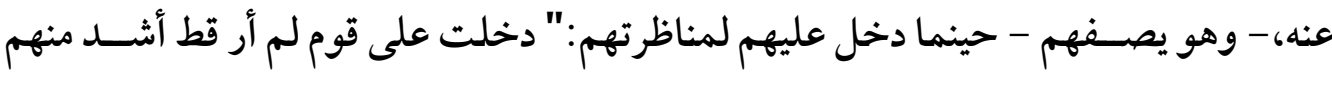

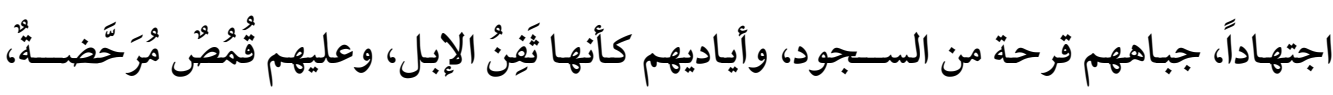

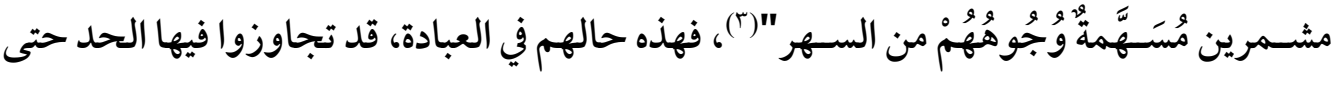
أصسبحوا ينظرون إلى مخالفيهم تلك النظرة القاسـية المتمثلة في تكفيرهم، واسـتحلال دمائهم وأموالهم.

فقد قادهم هذا الغلو إلى مخالفة قواعد الإسـلام، بما تُمِليه عليهم عقولهم، فكانت مظاهر

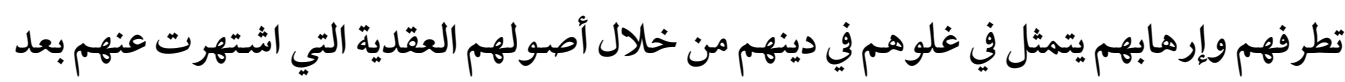

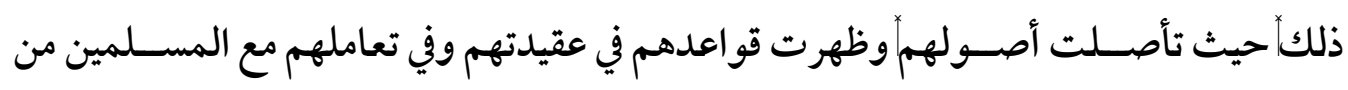

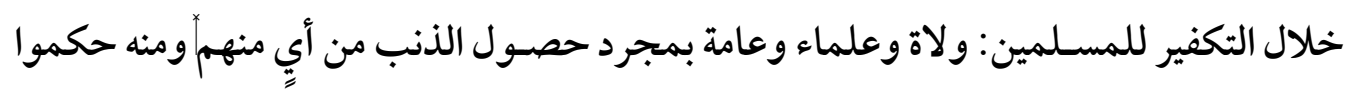
على علي بن أبي طالب وقبله عثمان بن عفان وعلى معاوية ومن معهم - رضسي الله عنهم

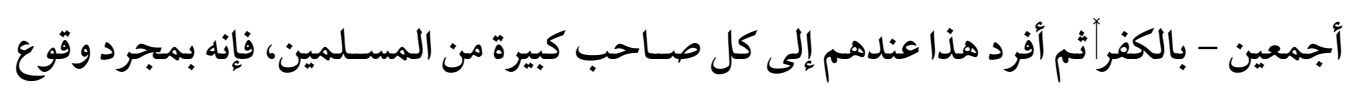

(1) الكامل في اللغة والأدب: أبو العباس بن يزيد المبرد، تحقيق: محمد أبو الفضـل إبراهيم، دار الفكر العربي،

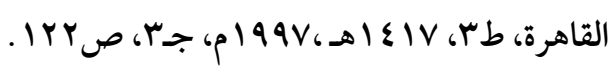

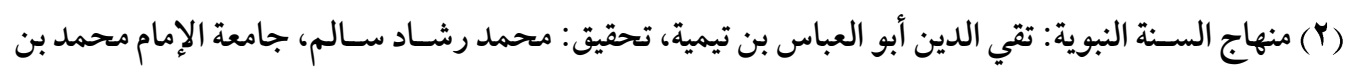

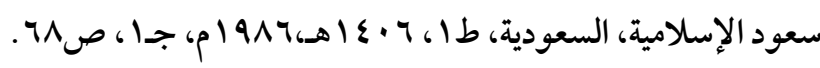

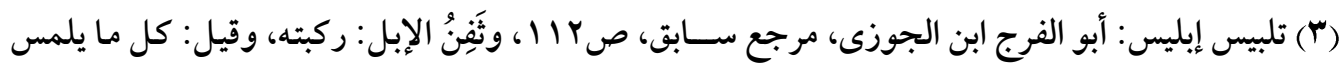

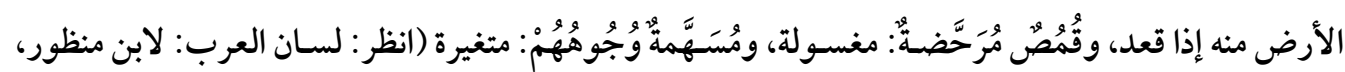

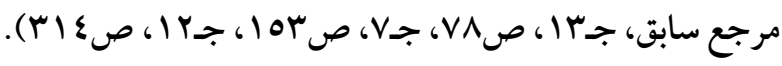


الكبيرة منه يكفر ويخرج من الملة، إلا أن يتوب فعليه الدخول في الدين مجددًا.

ومنهم من بالغ في ذلك حتى على كل من ارتكب ذنبًا، من الذنوب ولو كان صــيرًا، فإنه كافر

مشـرك مُخلّد في النار، وكان من نتيجة هذا الغلو الذي خرج بهم عن حـدود الدين وأهدافه الســامية، أن كفَّروا كـل من لم ير رأيهم من المســمين ورموهم بـالكفر أو النفـاق، فكفروا المجتمعات المســلمة، حتى إنهم اسـتباحوا دماء مخالفيهم، ومنهم من اسـتباح قتل النســاء والأطفال من مخالفيه (')، وهكذا صـور كثيرة من الظلم والاعتداء ارتكبها هؤلاء لأجل غلوهم في دين الله تعالى.

ونسـتطيع القول بأن طبيعة التكوين الفكري لغلو الخوارج قد تحكم فيه عاملان: عامل بيئي، وآخر ديني، فأما العامل البيئي فيتمثل في أن الغالبية العظمى منهم كانت من الأعراب، حيث كانت بداوة الأعراب بما طوت من حدة وخشــونة وحماس جارف وتســرع في إبداء الر أي والتطرف فيه، فضلاً عن طبيعتهم المميزة التي اكتسبوها من بيئتهم الصحر اوية القاسية والجبلية الوعرة.

ويؤكد الدكتور أحمد محمود صـبحي هذا الأثر البيئي بقوله:" فالطبيعة القاسـية والمناخ القاري - الذي لا يعرف الاعتدال - لا بد أن ينعكســا على نمط تفكير الإنســان وعقيدته، كما ينعكسـان على حياته الثـخصـية، ومن ثم كان التطرف إلى حد تكفير المخالفين وقتل النســاء

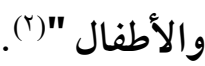

فإذا انتقلنا من العامل البيئي إلى العامل الديني نجد أكثرهم من القراء، وذلك يشـير إلى نمط

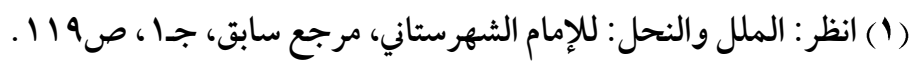

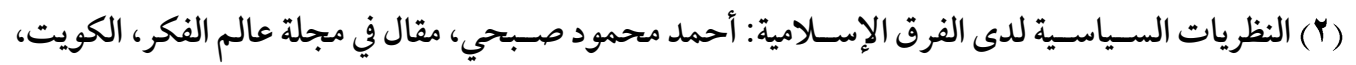

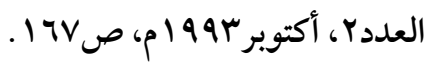


اعتقادهم، فهم أكثر الفرق الإســلامية اســثــهـاداً بالآيات القرآنية مع الوقوف عند المعنى الظاهري منها، وأقلها استناداً إلى الأدلة العقلية، ولكنها أقلها حظكًا من علم أو فكر أو حضـارة،

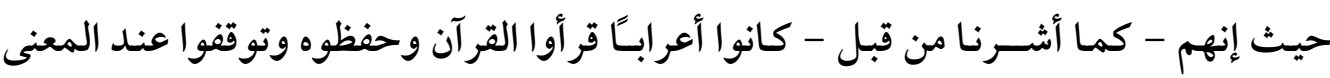

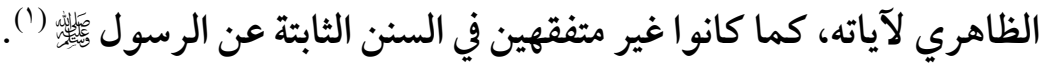

ولا شـك أن الخوارج بما اتُصَّفـوا به من الجهل والجفاء والغلو قد شـوَّهوا محاســن الدين الإسـلامي، تشـويهًا غريبًا، فإن هذا الغلو أخرجهم عن روح الإسـلام وجماله واعتداله، وهم في

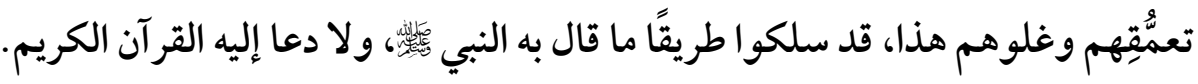

وقد طمِعوا في الجنة وأرادوا السـعي لهاعن طريق التعمُقق والغلو في الدين، غلوًا أخرجهم عن

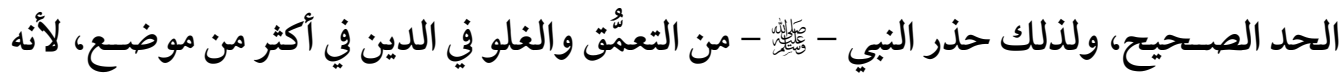

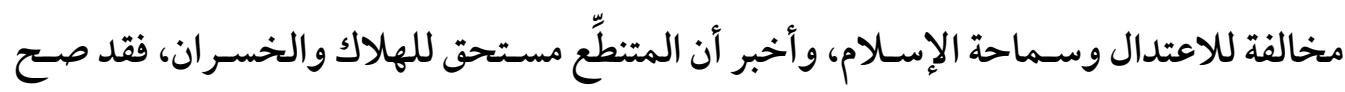

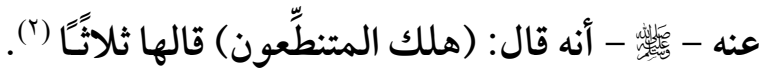
وبهذا يتبيَّن لنا شـذوذ الخوارج، و كذلك كل من ســار على منهجهم المبني على التعسُّــــ والغلو المخالِف لسماحة الإسلام ووسطيته.

\section{ملاج ظاهرة الغلو:}

إن علاج أي داء لا يتحقق إلا بـالتشـخيص الدقيق لـه وتلمس أسـبـابه وأعر اضــه، وبـدون التشخيص الصحيح فالعلاج لن يفيد ونستطيع الحكم عليه بالفشل.

(1) انظر: الفصل في الملل والأهو اء والنحل: ابن حزم الظاهري، مرجع سابق، جـ \&، ص إ I، وتيارات الفكر

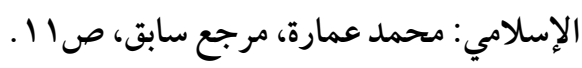
(ץ) أخرجه الإمام مسـلم في صسحيحه، كتاب: كتاب العلم، باب: النهي عن اتباع متثــابه القرآن والتحذير من صن متبعيه، حديث رقم • rTV. 
ومعالجة الأسباب هي أول خطوات محاربة الغلو وضربه بمقتل، وبذلك نوفر الجهد والوقت والمال، إذل لا يمكن معالجة أي ظاهرة من الظواهر إلا بمعرفة أسـباب نشــأتها، فإذا علمنا أن أسباب الغلو إما عدم فهم الإسلام على حقيقته، وإما اتباع الهوى والتعصب الأعمى، وإما اتباع المتشابهات وترك المحكمات، وإما الفراغ الروحي الذي يحيط بالشباب، أو البعد عن العلماء وترك التلقي عنهم، أو غيرها من الأسـباب التي تحدثنا عنها سـابقًا، سـهل علينا وضـع الحلول والدراسات لمعالجة هذه الظاهرة الخطيرة.

ولا يوجد علاج جامع مانع شـاف مبرئ إلا من خلال التمسـك بالكتاب والسـنة الصسحيحة، عملاً وقولاً واعتقادًا في شتى ميادين الحياة، على علم وهدى وبصيرة، لا بهوى وجهل . والالتزام كذلك بمذهب السلف الصالح، لأنهم هم الذين يحققون الوسطية، ويطبقون منهج الثرع، وهم الذين يفهمون المقاصد الثرعية والنصوص من المصدرين على الوجه الصحيح،

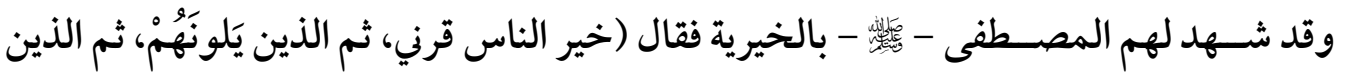

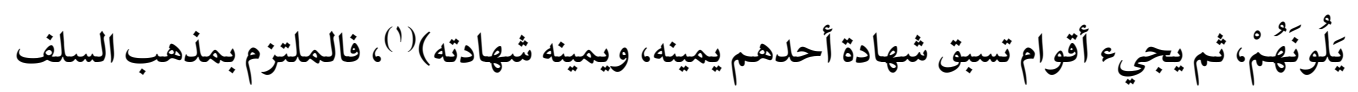
محقق لمعنى الوسطية، معتصم بالهدى، مقيم على أمر الله. فلا بد من تقرير هذين الأمرين العظيمين، والدندنة عليهما في شـتى الميادين، والسـعي إلى تحقيق ذلك في ميدان العمل والتطبيق ليجني الناس ثمارهما الطيبة. ولا مر اء في أن الغلو بل وجميع الانحر افات بأثـكالها المتعددة إنما نبتت على سـاحة الفكر الإســلامي كتيجة حتمية للإعر اض عن الكتاب والسـنة، وترك الاهتداء بنورهما الوهاج، ومن ثم فيكمن العلاج في الرجوع إليهما والاعتصــام بهما، والأخذ بتوجيهـما، فهما المصــدران (1) أخرجه الإمام البخاري في صحيحه، كتاب: الشهادات، باب: لا يشهد على شهادة جور إذا أشهد، حديث

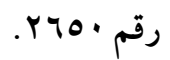


النيران اللذان من اعتصـم بهما هدي إلى النهج السـوي، والطريق القويم كما قال سـبحانه (وَمَنْ

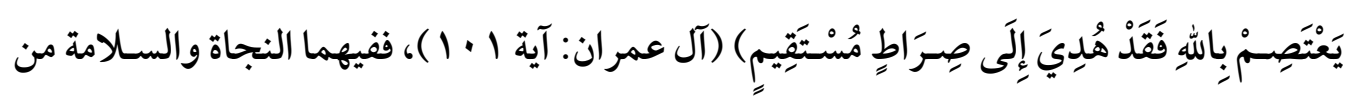
الغلو ومن أي انحراف.

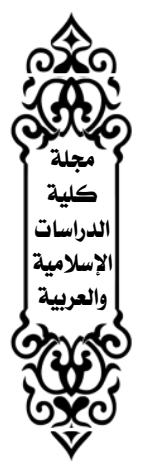




\section{الاطلب الثالث}

\section{ظاهرة الشدة والغلظة}

وضـع الشـارع الثـريعة في الأصـل على مقتضسى قدرة الإنسـان ووسـعه، وجعل للمشـقات العارضسة رخصَّا تخففها رحمة بعباده وتيسيرًا عليهم، ونهى عن الشـدة والغلظة لما في ذلك من مشقة على النفس وإضرار بها، وتضييق على الناس في معايشهم وتصرفاتهم، وخروج عن سنة

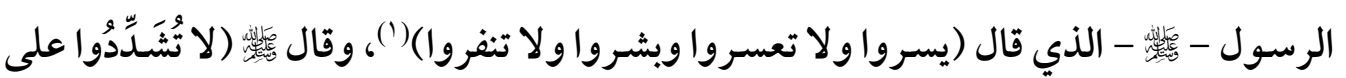

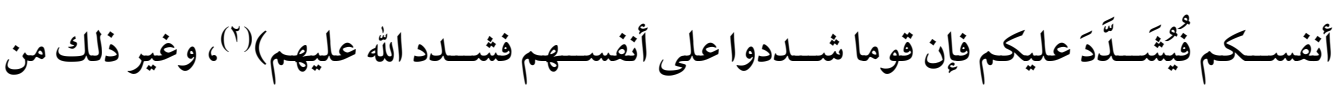
الأحاديث الكثيرة التي تنهى عن الشدة والغلظة.

وعلى الرغم من كثرة النصــوص القر آنية والتوجيهات النبوية التي تأمر المســلمين بـالرفق

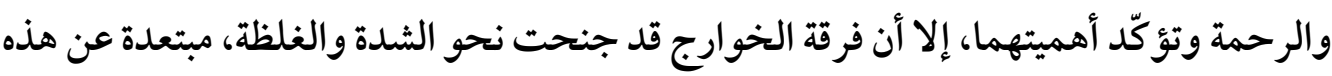
النصـوص وتلك التوجيهات، ضـاربة بهاعُرض الحائط، ومؤسســة نظامًا جديدًا في التعاملات

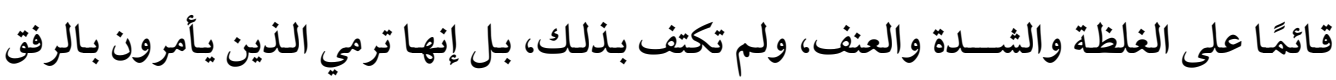
والرحمة والتسامح بالكفر والبدعة وموالاة أعداء الله. فالخوارج أوجدوا التشـدد، حتى إن السيدة عائشـة - رضي الله عنها - لما سـألتها تلك المر أة عن الحائض تقضى الصوم ولا تقضى الصلاة، قالت: أحرورية أنت ؟ (ّ). فالتعمق في الدين والتشــد والغلظة فيه من أكبر ســمات الخوارج، فقد تشــددوا وتعمقوا في

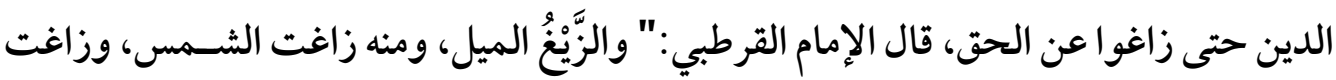

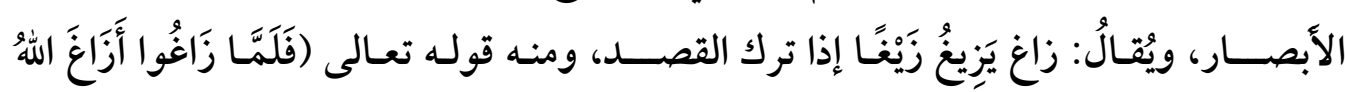

(1) أخرجه الإمام البخاري في صحيحه، كتاب: العلم، باب: ما كان النبي - ( - يتخولهم بالموعظة والعلم كي

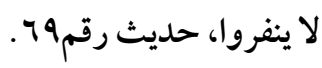

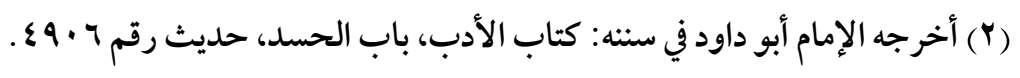

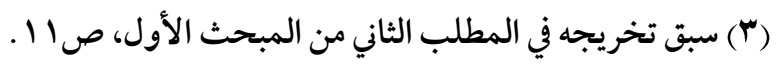


قُلُوبَهُمْ)(الصـف: آية ه )، وهذه الآية تَعُمُ كل طائفة من كافر وزِنديق وجاهل وصـاحب بدعة،

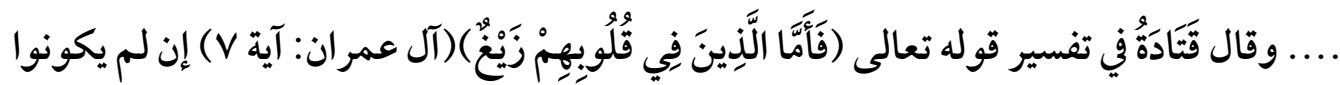
الْحَرُورِيَّةَ وأنواع الخوارج فلا أدري مَنْ هم "( ).

ومن ثم عُرف الخوارج بـالغلظة والثـــدة والجفوة، وكانوا شــديدي القســوة والعنف على المسـلمين، وقد بلغت شــتهم حداً فظيعـا، فاسـتحلو ادماء المسـلمين وأمو الهم و أعر اضـهم فروعوهم وقتلوهم، وأما أعداء الإســلام فقد تركوهم ووادعوهم فلم يؤذوهم، ولقد ســـل التاريخ صحائف سوداء للخوارج في هذا السبيل.

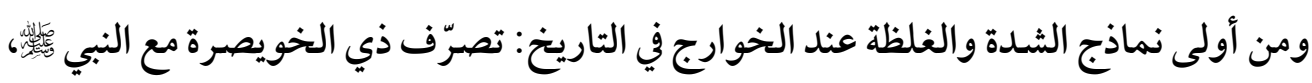

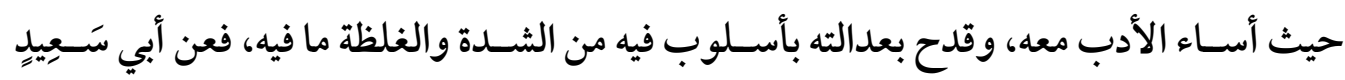

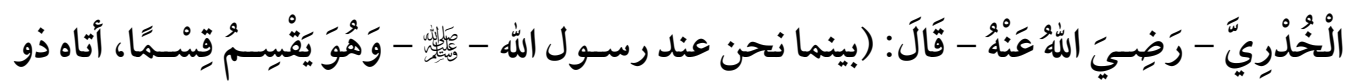

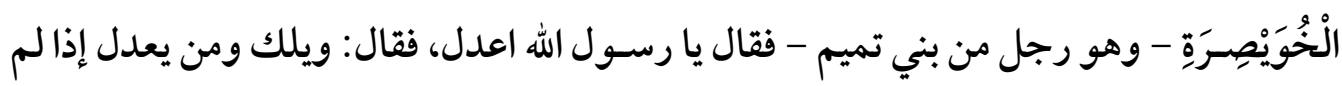

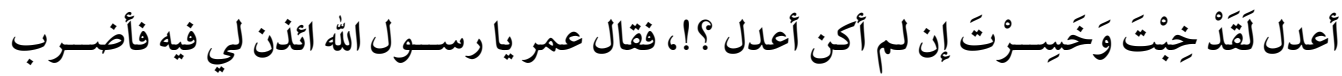

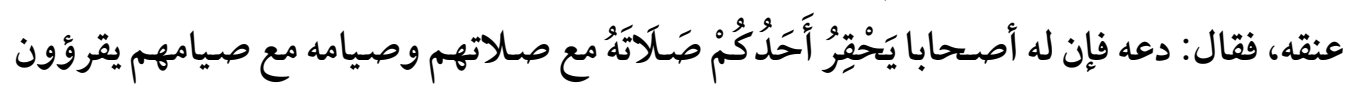

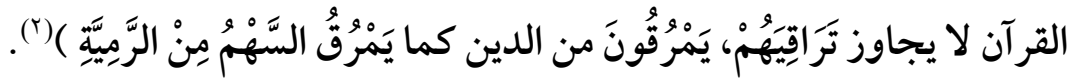

ومن ذلك أيضًّـا ما جاء في قصسة مقتل خبّاب بن الأرت رضسي الله عنه، قال الحافظ ابن حجر العسقلاني:" فاستعرضـوا الناس (أي: الخوارج) فقتلوا مَن اجتاز بهم من المسـلمين، ومرَّ بهم

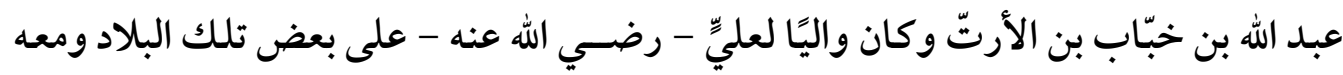

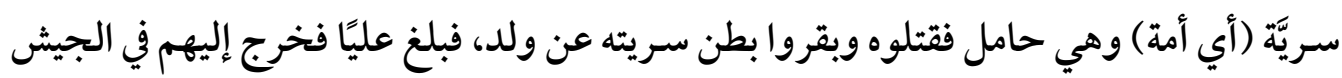

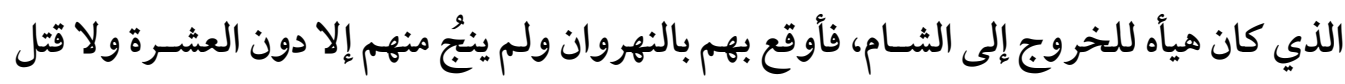
(1) تفسـير القرطبي: الإمـام شـمس الدين القرطبي، تحقيق: أحمـد البردوني وإبراهيم أطفيش، دار الكتب

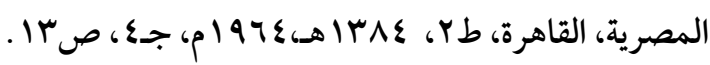

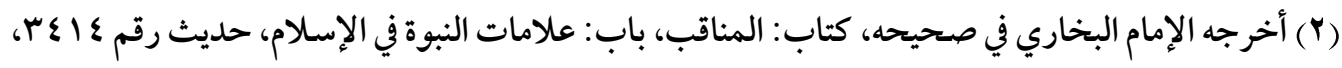
وأخر جه الإمام مسلم في صحيحه، كتاب: الزكاة، باب: ذكر الخوارج وصفاتهم، حديث رقم ץ؟ ا. 
فمعاملة الخوارج للمسلمين مصحوبة بالقسوة والشدة والعنف، وأما للكافرين فلين وموادعة ولطف، وبهذا خالفوا أمر الثـارع الذي ندب إلى اسـتعمال الثــدة والغلظة مع الكفار، وإلى

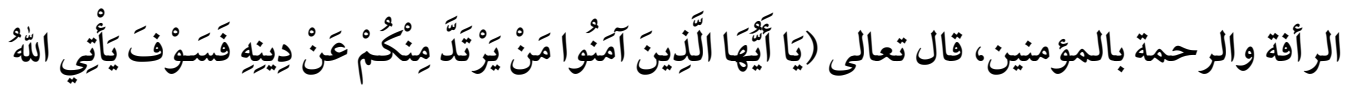

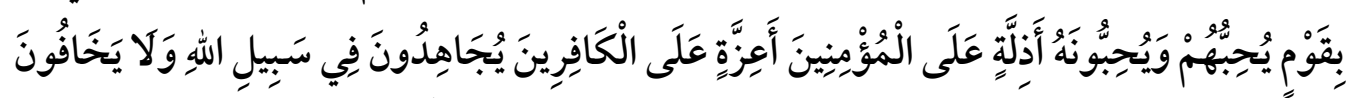

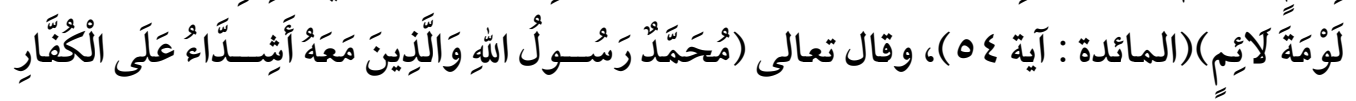

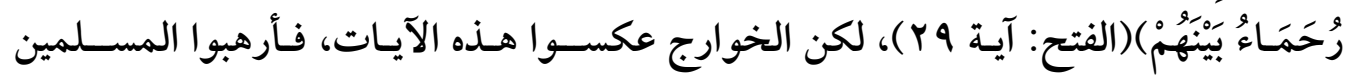
وروعوهم، في الوقت الذي تعاملوا فيه مع الكافرين بالر أفة والرحمة. ومن تشــديدهم في الأحكام الثـرعية، حيث أوجب بعضـهم الصــلاة الفائتة على الحائض في زمن حيضها، وقطعوا يد السارق من إبطه، ولم ير اعوا نصاب السرقة، فقطعوا في القليل والكثير،

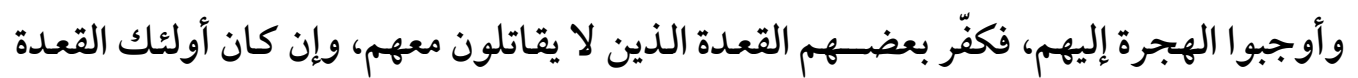
على مذهبهم الفاسد، ولم يعذر بعضهم حتى النساء في ترك الهجرة إليهم (؟). ولقد تأثر بعض الثـباب بهذا الأسـلوب الخوارجي، فاسـتخدموا أسـلوب الغلظة والثــدة

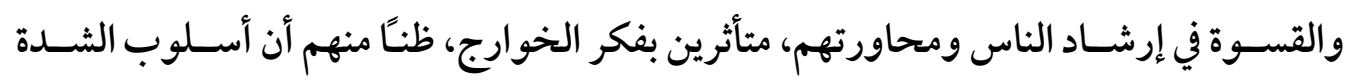
والغلظة هو المجدي والر ادع، حتى أصبحت الثدة هي الطابع الغالب على سلوك الكثير منهم، وقد تجاوزت هذه الشدة حدود القول إلى العمل| فسفكت دماء بريئة بسببه ودمرت منشآتأ كما تسببت هذه الشدة والغلظة والعنف في أضرار فادحة على أصحابها وعلى الأمة الإسلامية. وهكذا مصسير من ترك المنهج الذي جاء به خاتم الأنبياء من العنف والثــدة والغلظة في الدعوة ومعاملة الناس، قال تعالى آمرًا موسـى وأخاه هارون -

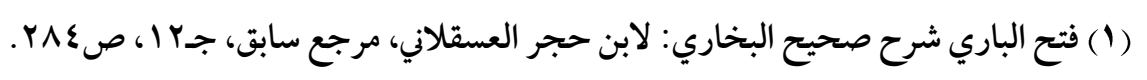

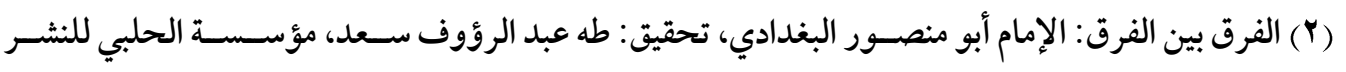

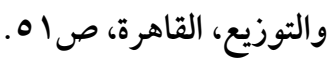




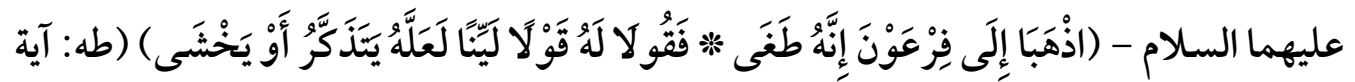

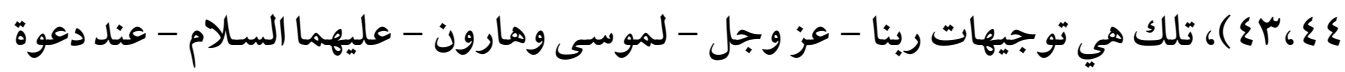
فرعون الطاغية القول اللين في بيان الحق لأنه أجدى وأقرب لقبول الذكرى وإحداث الخشية.

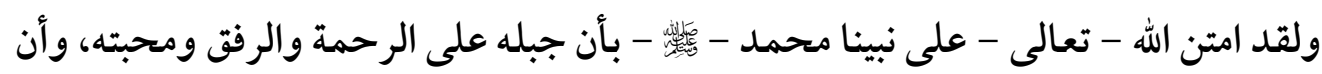

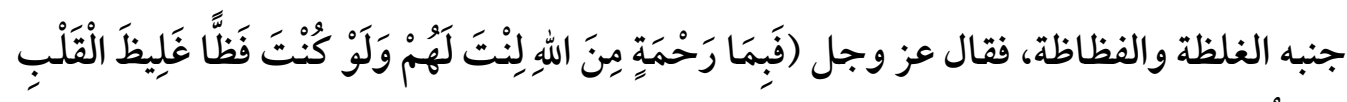

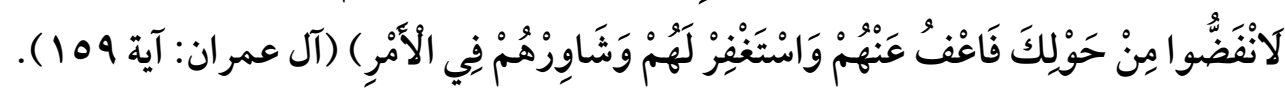

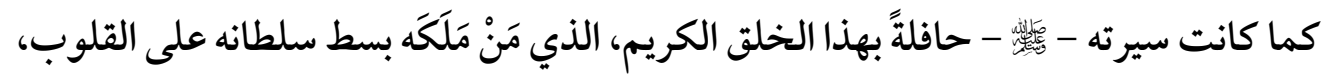

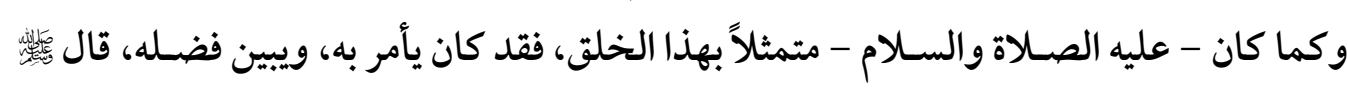
(إن الله رفيق يحـب الرفق، ويعطي على الرفق ما لا يعطي على العنف، ومـا لا يعطي على ما

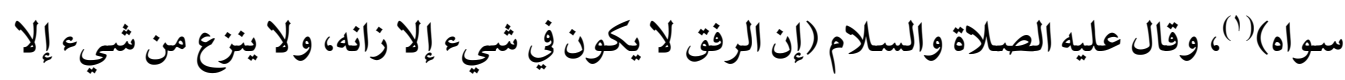

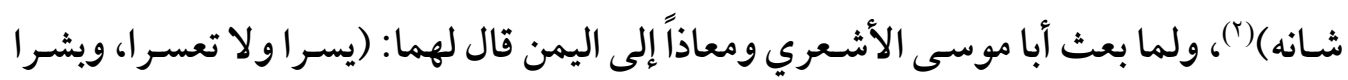
ولا تنفرا، وتطاوعا ولا تختلفا)(").

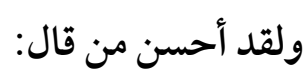
لو سار ألف مدجج في حاجة ... لم يقضها إلا الذي يترفق (s)

$$
\begin{aligned}
& \text { (1) أخرجه الإمام مسلم في صحيحه، كتاب: الآداب، باب: فضل الرفق، حديث رقم بهه r. }
\end{aligned}
$$

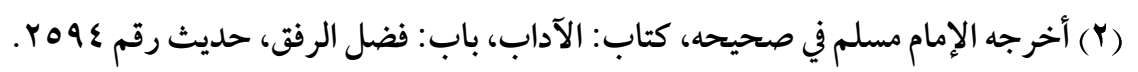

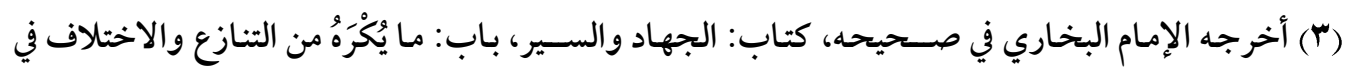

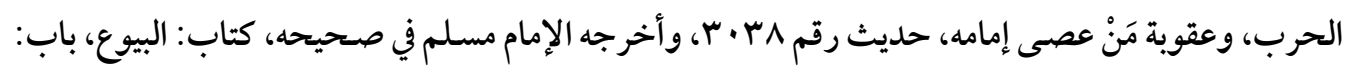

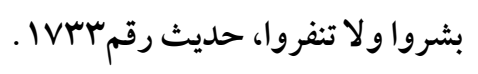
(ع) روضــة العقلاء ونزهة الفضــلاء: أبو حاتم محمد بن حبان الدارمي، المحقق: محمد محي الدين عبد

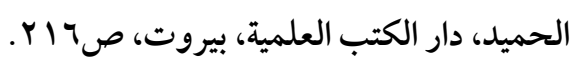




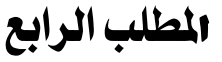

\section{ظاهرة الجدل وميلهم إليه وقوتهم فيه}

خلق الله - تعالى - الإنســان ناطقًا مفكرًا يتوارد عليه من الخواطر والمعلومات ما يجعله مدفوعا بالضـرورة إلى الإفضـاء بها والإفصـاح عنها، وبما أن الإنسـان مدني بطبعه لا يعيش إلا داخل جماعة من بني جنسـهـ يتفاعل معهمّ يؤثر فيهم ويتأثر بهم ئأتي الجدل كمطلب من أهم متطلبات هذا التفاعل، لكي يعبر به عما يختلج في نفسه من مقاصد و أغر اض، بصرف النظر عن كيفية هذا البيان ونوعيته من جهة، ومن جهة أخرى من أجل اسـتجلاب الحقوق ودفع المظالم وإعلاء الحق ودحض الباطل.

فالجدل ظاهرة إنسـانية، بل عالمية لوجودها في الأجناس البشـرية وغيرها، قال الزجاج:" كل

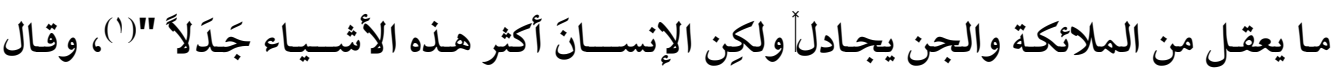
الألوسي:" (وكان الإنسـان) بحسب جبلته (أكثر شيء جدلا) أي أكثر الأشياء التي يتأتى منها الجدل ... والمعنى: أن جدل الإنسان أكثر من جدل كل مجادل "(؟). ولما كان الجدل يمثل نزعة إنسانية، لأنه طبيعة في الفطرة الإنسانية جاءت النصـوص الثـرعية في القرآن الكريم والسنة النبوية تارة بمدحه، وأخرى بذمه.

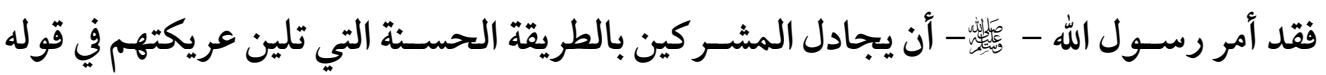

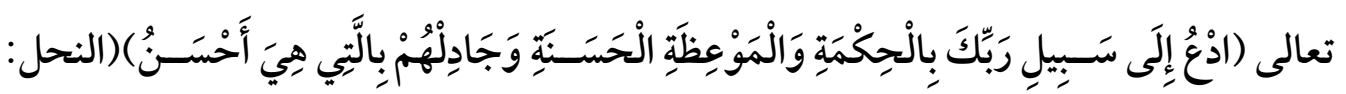

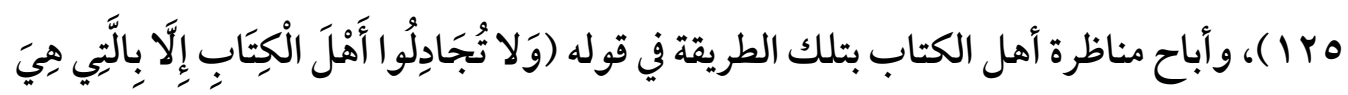

(1) معاني القرآن وإعرابه: أبو إسـحاق الزجاج، تحقيق: عبد الجليل عبده شـلبي، عالم الكتب، بيروت، طا،

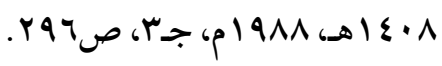

(r) روح المعاني: شـهاب الدين الألوسـي، تحقيق: علي عبد الباري عطية، دار الكتب العلمية، بيروت، طا،

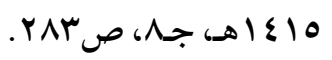


أنكار الثوارج بين الماضي والحاضر عرض ومناقشح

\&

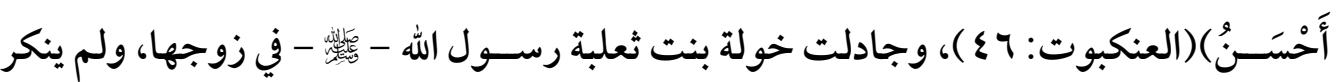

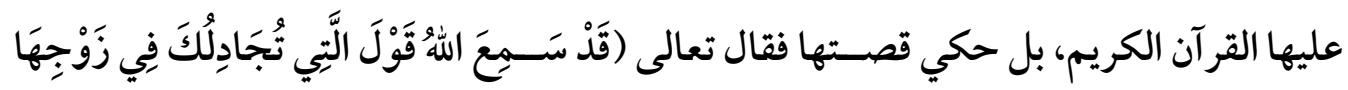

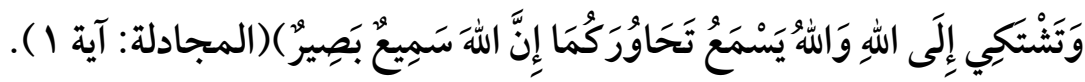

وبهذه النصسوص وغيرها يتبين لنا مشـروعية الجدل بالحسـى، وهو الجدل المحمود، فهو من قبيل المناظرة التي تهدف إلى إظهار الحق، وإقامة البرهان على صحته وإزالة الشبه.

ودل على ذلك الإمام الشوكاني بقوله:" فأما الجدال لاستيضـاح الحق، ورفع اللبس، والبحث عن الر اجح والمرجوح، وعن المحكم والمتثــابه، ودفع ما يتعلق به المبطلون من متثــابهات القرآن، وردهم بالجدال إلى المحكم فهو من أعظم ما يتقرب المتقربون "('). وبمثله أشــار الإمام الزمخثـري بقوله:" فأما الجدال فيها (أي في آيات الله تعالى) لإيضــاح ملتبسها وحل مشكلها، ومقادحة أهل العلم في استنباط معانيها ورد أهل الزيغ بها وعنها، فأعظم جهاد في سبيل الله "(؟) - ( )

أما النصــوص التي ورد فيها ذم الجدل فهي كثيرة، منها ما ورد في ذم الجدل بغير علم كقوله

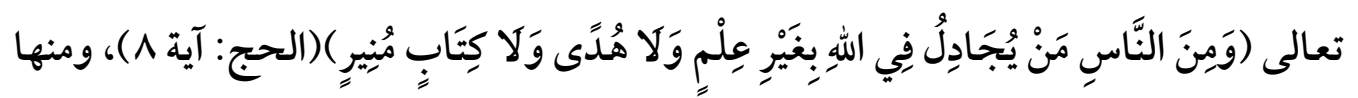

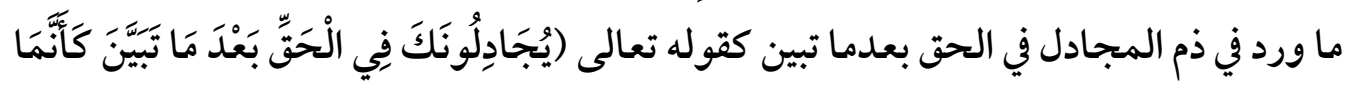

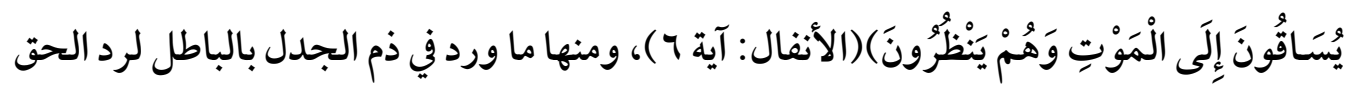

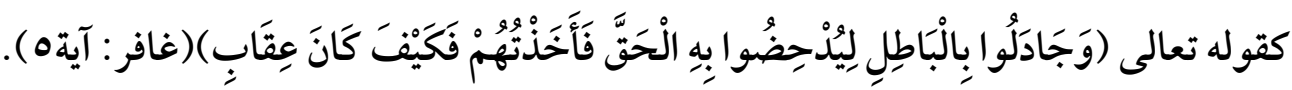

(1) فتح القدير : الإمـام محمد بن علي الشـوكاني، دار ابن كثير، دار الكلم الطيب، دمشـق، بيروت، ط1، ـ

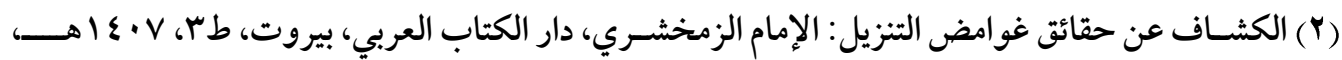

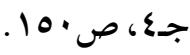


فهذه النصـوص وغيرها مما جاء فيها الحديث عن ذم الجدل، تتحدث عن الجدل المذموم، وهو كل جدل ناصسر الباطل أو أفضسى إليه، وهو الذي يغلب على أصسحابه حب النفس واتباع الهوى فيغلب عليهم التعصــب الأعمى ويسـيطر عليهم الغضــبـ مما يفضسى في النهاية إلى المنازعة والمخاصمةً وربما أدى إلى أسوء من ذلك.

قال الإمام الجويني:" ومن الجدل ما يكون مذمومًا محرّمًا، فالمذموم منه ما يكون لدفع الحق، أو تحقيق العناد، أو ليُّبِسَ الحق بـالباطل، أو لما لا يطلب بـه تعرُّفُ ولا تقرُُّّ، أو للمماراة وطلب الجاه والتقدم، إلى غير ذلك من الوجوه المنهيّ عنها، وهي التي نص الله - سـبحانه - في

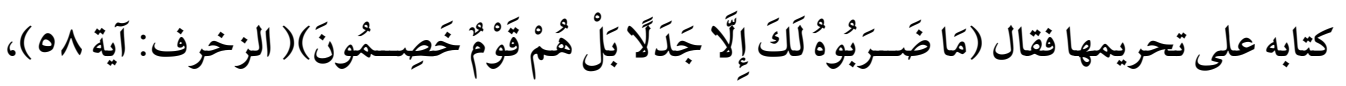

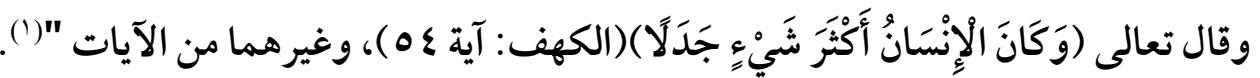

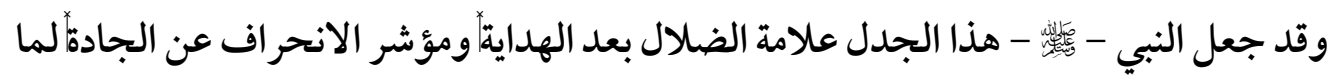

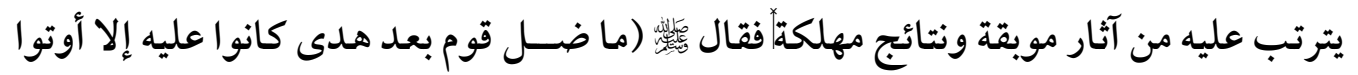

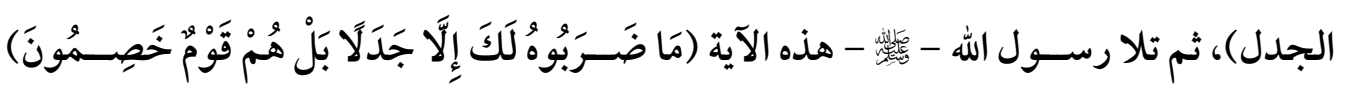

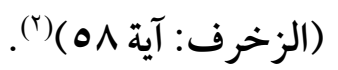

وبناءً على ما سبق، يتضح لنا أن الجدل منه ما هو محمود، ومنه ما هو مذموم، وأن وصفه بهذا أو ذاك يتوقف في المقام الأول على الهدف المنثــود من ورائه، والأدلة المســتخدمة لتحقيق (1) الكافية في الجدل: الإمام الجويني، تحقيق: فوقية حسـين محمود، طبعة مكتبة عيسى الحلبي، القاهرة،

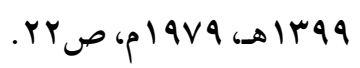

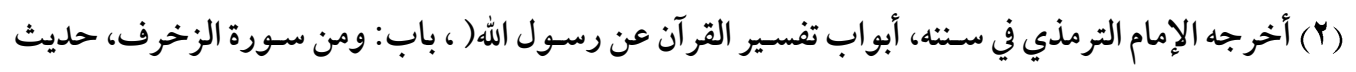

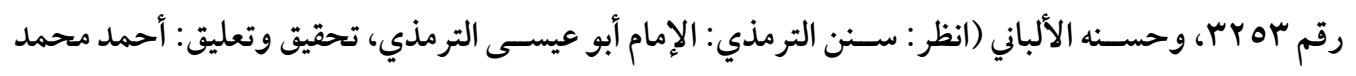

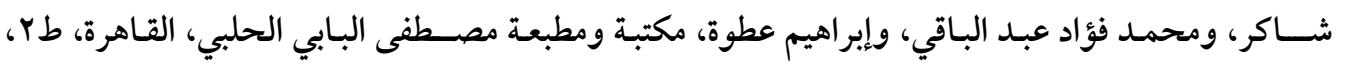

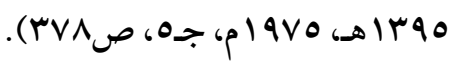


ذلك، فإذا كان الهدف منه الانتصارَ للحق، واستخُحِدَمَت الأدلة والبر اهين على ذلك، سواء اقتنع بها الخصم أم لا، فهو جدل محمود، وما كان بخلاف ذلك، فهو جدل مذموم.

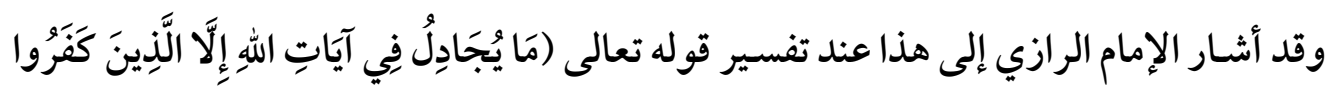

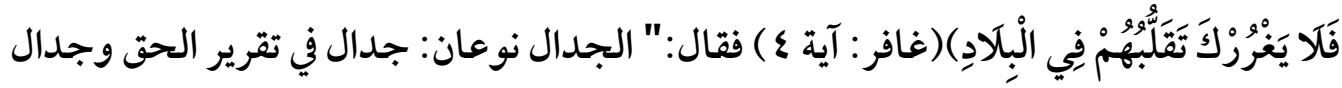
في تقرير الباطل، أما الجدال في تقرير الحق فهو حرفة الأنبياء عليهم السـلام، قال تعالى لمحمد

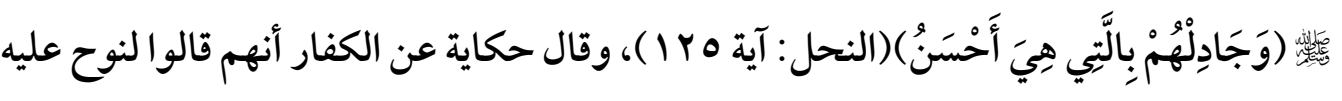

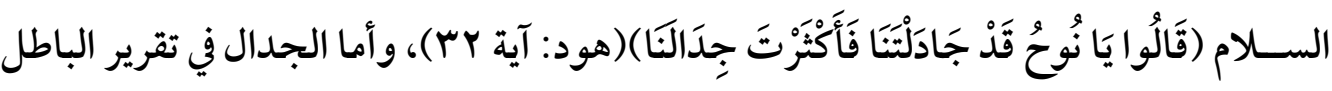
فهو مذموم وهو المر اد بهذه الآية حيث قال (مَا يُجَادِلُ فِي آيَاتِ اللهِ إِلَّا الَّذِينَ كَفَرُوا)(غافر : آية

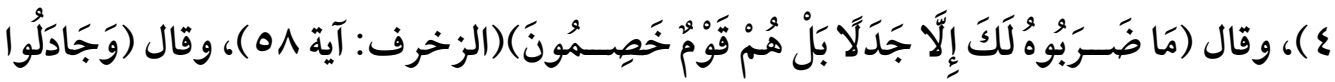

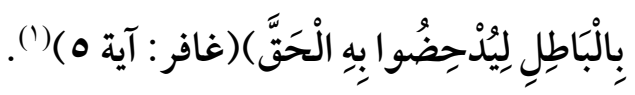
وإذا ما جئنا إلى الخوارج، نجد أنهم قد بذلوا في الدفاع عن آرائهم وجعل السـيطرة لها على الناس جهدًا كبيرًا، ســواء كان ذلك بقوتهم الحربية أو كان بقوتهم الجدلية التي كانت من أهم سـماتهم التي اشـتُهروا بها، فكثرة المراء، والإسـراف في الجدال، كان من أسسباب صـرفهم عن

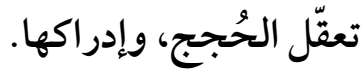
قـال أبو العبـاس المبرد:" وكـان في جملـة الخوارج لـدد واحتجـاج، على كثرة خطبـائهم وشعر ائهم، ونفاذ بصيرتهم، وتوطين أنفسهم على الموت "(()، بل إن الأسلوب الذي اتبعوه في مناقشة علي بن أبي طالب وابن عباس - رضي الله عنهما - تصديقُ لرسوخ تلك الصفة فيهم، حتى إن أحد أئمتهم، وهو نافع بن الأزرق، جعل يسـأل ابن عباس - رضسي الله عنه - يومًا حتى

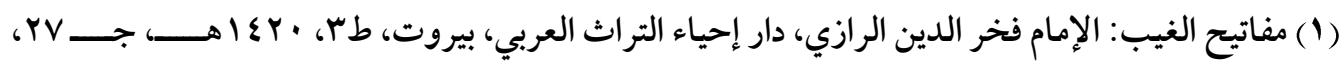
صמת.

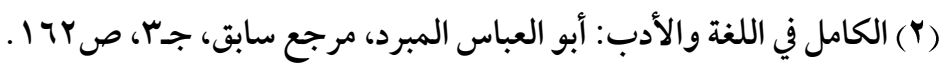


أَمَلَّهُ، فجعل ابن عباس يُظْهِهر الضّجر ('). وقد حفلت كتب التاريخ والأدب بذكر مجادلاتهم مع الإمام علي وابن عباس وغيرهما من أعلام المســلمين، كعبد الملك بن مروان وعمر بن عبد العزيز، ويطول بنا القول لو ذهبنا نذكر أخبار تلك المناظرات والمحاورات التي دارت بينهم وبين خصومهم، والتي ظهرت فيها قوتهم في الجــدال ولـددهـم في الخصــومـة، وذلـك لكثرة هـــه الأخبـار وطول تلـك المنـاظرات

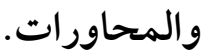

بل لقد كان عقلاء الخوارج ومفكروهم يشكون من كثرة انتشار الجدل بينهم، والذي كان سببًا مباشرًا من أسباب تفرق الخوارج، على نحو ما يصفه الصلت بن مرة بقوله:

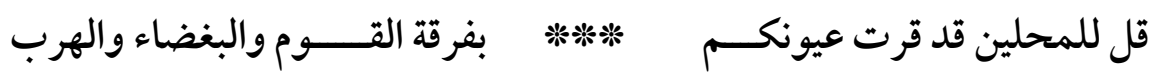

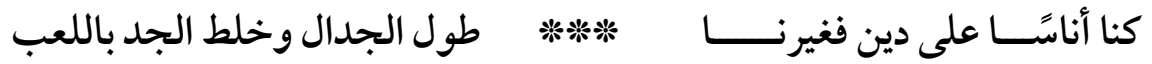

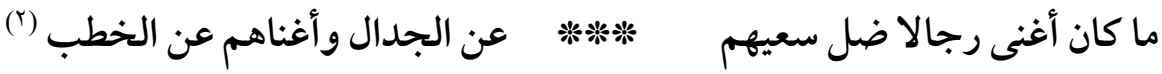
وحذر النبي - - ولئ - أيضـا من قدرتهم على التضـليل بحسـن الكلام والبلاغة والجدل، فقال في روايات متعددة: إنهم يحسنون القيل ويسيئون الفعل، ويتكلّمون بكلمة الحق، ويقولون من خير قول البريّة (")، لذا كانوا يطالبون عليًا - رضي الله عنه - بتطبيق الثـرع رافعين شعار " لا حكم

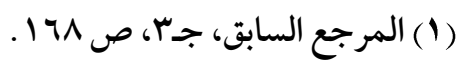

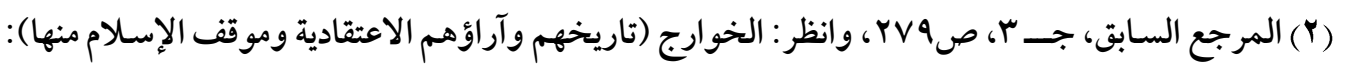

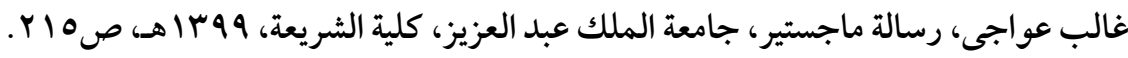

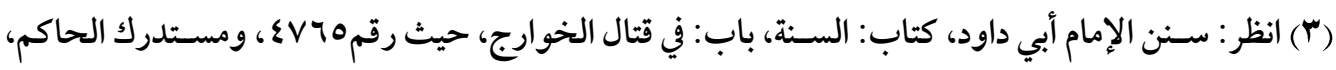

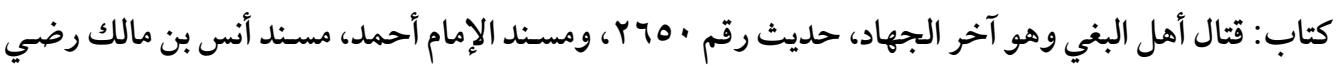

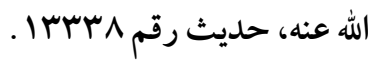


وقد اتصف الخوارج بصفات متميزة رفعت من جدلهم، بل وجعلتهم قومًا خصمين، يجادلون عن أفكارهم ومعتقداتهم باندفاع وحماس وعنف، ومن أبرز هذه الصفات:

\section{اــ الفصاحة وطلاقة اللسان ومعرفة طرق التأثير على السامعين: اشتهر الخوارج بالفصاحة وقوة}

الأسلوب وعرض مذهبهم والدعوة إليه بصورة شيقة تجذب إليهم القلوب وتتأثر بكلامهم أيما تأثر، فلهم خطب وأشعار وأمثال ومناظرات مشهورة في كتب الأدب تتميز بفصاحتها وقوة

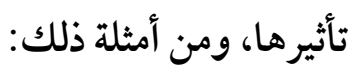

" أن عبد الملك بن مروان أتي بر جل منهم فبحثه فر أى منه ما شــاء فهمًا وعلمًا، ثم بحثه فرأى منه ما شــاء الله أدبًا ودهيًا (أي عاقلاً مجربًا)، فرغب فيه واسـتدعاه إلى الرجوع عن مذهبه فرآ مسـتبصـرًا محققتًا، فزاده في الاســدعاء فقال له: لتغنك الأولى عن الثانية وقد قلت فسـمعت فاسمع أقل، قال له: قل: فجعل يبسط له من قول الخوارج ويزين له مذهبهم بلسان طلق وألفاظ بينة ومعان قريبة، فقال عبد الملك بعد ذلك على معرفته: لقد كاد يوقع في خاطري أن الجنة خلقت لهم وأني أولى بالجهاد منهم، ثم رجعت إلى ما ثبت الله علي من الحجة ووقر في قلبي من الحق فقلت له: لله الآخرة والدنيا، وقد سلطني الله في الدنيا ومكن لنا فيها وأراك لست تجيب بالقول، والله لأقتلنك إن لم تطع "((). كما وصف ابن زياد أسلوب الخوارج وقوة بيانهم بقوله:" لكلام هؤلاء أسرع إلى القلوب من النار إلى اليراع (القصب الفارسي)"(().

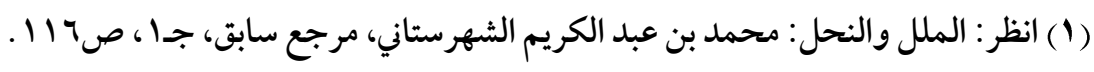

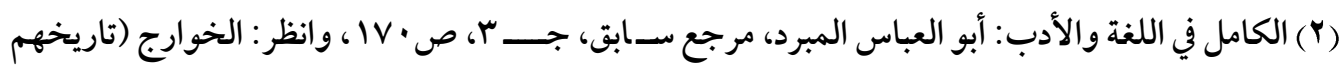

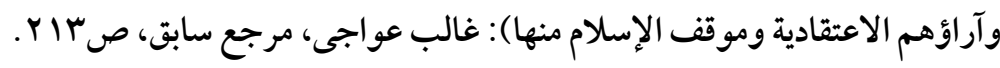

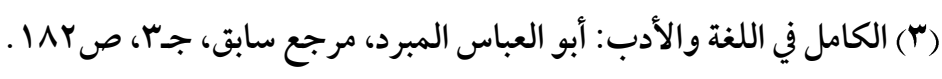


ووصفهم الشيخ أبو زهرة بقوله إنهم:" اتصفوا بالفصاحة وطلاقة اللسان، والعلم بطرق التأثير

البياني، وكانوا ثابتي الجنان، لا يتحيرون أمام خصومهم، ولا تأخذهم حبسة فكرية "( ).

rـالشجاعة الثادرة: بلغ الخوارج القمة في الإقدام على الموت في ساحات القتال لا يهابون بطش أحد ولا يقف دون غضبهم حاجز، واشتهروا بالشجاعة النادرة والاستبسال في المعارك.

وقد شــهد لهم الكثيرون بذلك، فصـاحب العقد الفريد يقول عنهم:" وليس في الفرق كلها

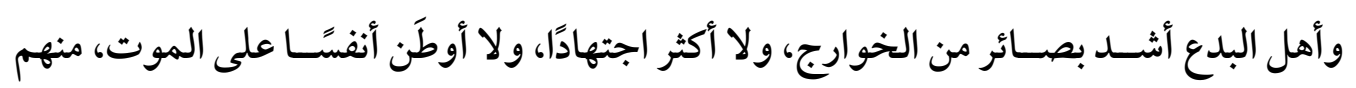
الذي طُعنَ فأنفذه الرمح فجعل يسعى إلى قاتله ويقول: عجلت إليك ربّ لترضى "((؟). وهذا أميرهم قَطَرِيّ بن الفُجاءة (َ) كان آية في الثـجاعة والإقدام، وبطلاً مغوارًا في الحروب لا يعرف قلبه الخوف، قال عنه الذهبي:" البطل المشهور رأس الخوارج قطري بن الفجاءة، خرج زمن ابن الزبير وهزم الجيوش واسـتفحل بلاؤه .... وله وقائع مشــهودة، وشـــاعة لم يُسْـمَعْ بمثلها "(8)، وقال ابن خلكان:" كان قطري رجلاً شـجاعًا مقدامًا كثير الحروب والوقائع ، قويّ

(1) تاريخ المذاهب الفكرية: الشيخ أبو زهرة، دار الفكر العربي، القاهرة، صه7.

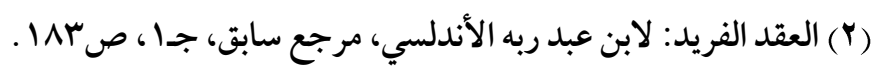

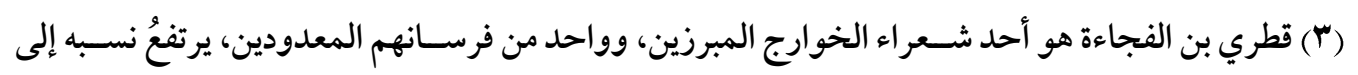

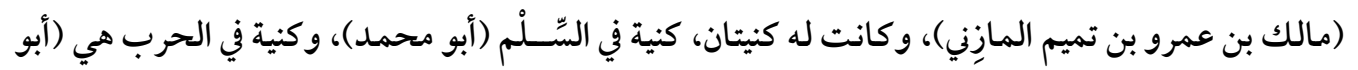

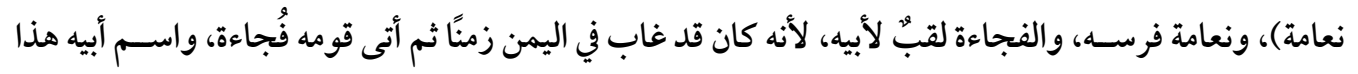

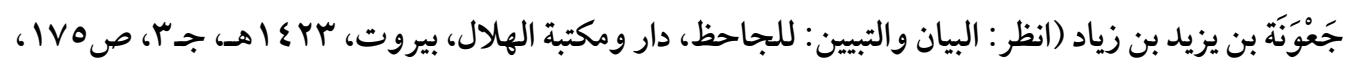

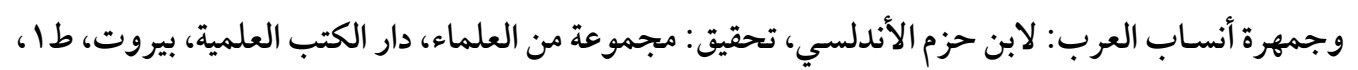

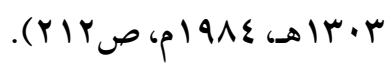

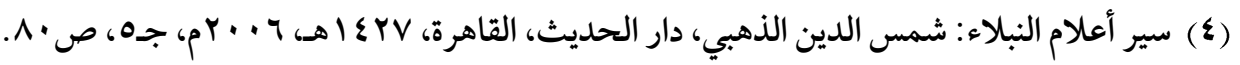


الفكار الخوارج بين الماضي والحاضر عرض ومناقشيح

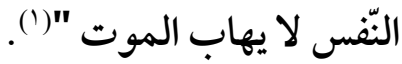

وأعتقد أن تلك الشجاعة وذلك الاستبسال لو وجه وجهة صحيحة لكان له أثر بالغ في مجرى التاريخ، ولكانوا جنودًا عاملين ومؤثرين في نشر الفتوحات الإسلامية بدلا من حربهم للمسلمين وإضعافهم لقوة الدولة الإسلامية.

זـ حبهم ورغبتهم في الجدل والمناقشة: فقد كانت عندهم رغبة جامحة في المناقشة والمجادلة واستعراض ما لهم من ملكات، ومساجلة الآراء والمذاهب، حتى أنهم في ساحات القتال كانوا

جاء في كتاب الأغاني:" كان الثراة والمسلمون يتواقفون ويتساءلون بينهم عن أمر الدين وغير ذلك على أمان وسـكون فلا يهيج بعضـهـم بعضًّا، فتو افق يومًا عبيدة بن هلال اليشـكري وأبو حُر ابة التميمي وهما في الحرب، فقال عبيدة: يا أبا حُر ابة إني ســائك عن أشــياء أفتصـــنى في الجواب عنها؟ قال: نعم إن ضـمنت لي مثل ذلك، قال: قد فعلت، قال: سـل عما بدا لك، قال: مـا تقول في أئمتكم ؟ قـال: يبيحون الـدم الحرام والمـال الحر ام والفرج الحرام، قـال: ويحـك فكيف فعلهم في المال ؟ قال: يجمعونه من غير حله وينفقونه في غير حقه، قال: فكيف فعلهم في اليتيم قال يظلمونه ماله ويمنعونه حقه، قال: ويلك يا أبا حر ابة أمثل هؤ لاء تتبع؟! "(().

وقد علق الثـيخ أبو زهرة على هذا فقال:" وترى من هذا أن حب المناقشــة والمناظرة قد اسـتولى عليهم، حتى كانوا يتو افقون مع مقاتليهم ليجادلوهم ويسـاجلوهم الأفكار والمذاهب

(1) وفيات الأعيان: أبو العباس شـمس الدين بن خلكان، تحقيق: إحســان عباس، دار صـادر، بيروت،

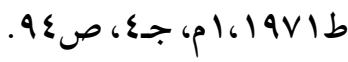

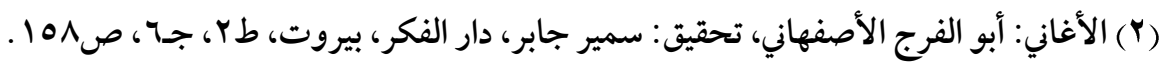


فجدل الخوارج لا يخرج عن الجدل الذي يكون ســبِّا في تحول المؤمنين إلى الضــلال بعد الهدى، أو الجدل الذي يُتتبع به الآيات المتثــابهات ومعارضــة المحكمات بها ابتغاء الفتنة وابتغاء تأويلها على غير مر اد الثـرع، مما يقتضسي التكذيب ببعض النصـوص، أو الجدل الذي يكون مماراة وخصومة في وجه أهل الحق، أو سببًا للفرقة والاختلاف والتنازع المذموم.

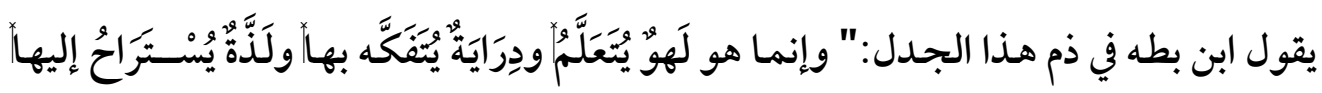

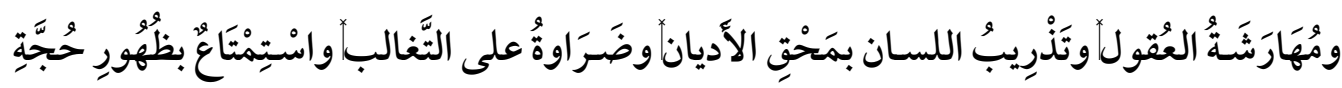

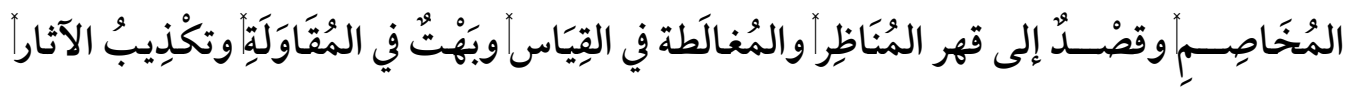

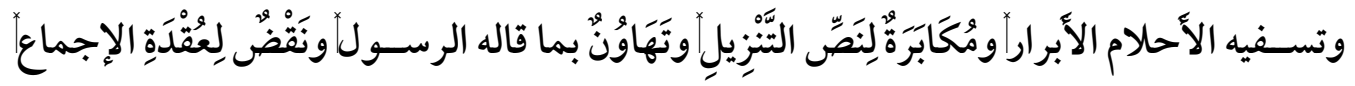

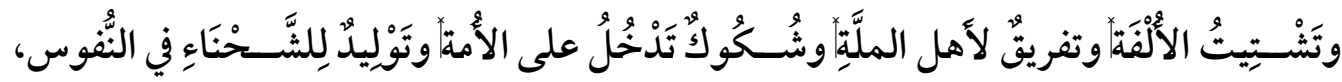
عصمنا الله وإياكم من ذلك "(؟). فالجدل إذا أصــبح ســمة للإنســان وأمته، فهذا منذر بوقوع مرضٍ خطير، إذ الجدل يفرق

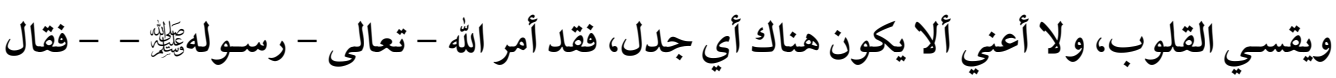

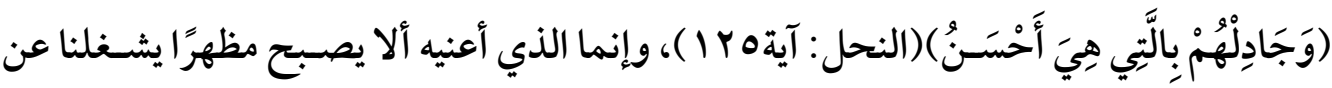
كتاب الله وعن سنة الرسول - - وعن - ذكر الله وطاعته.

كما لا أعني أن نترك الحوار الذي يؤدي إلى الحق، ولكنى أريد ألا يتعمق هـذا الجدل فينـا وننشغل به، بحيث يفرقنا ويقسي قلوبنا، بل ينبغي أن يكون همنا دائمًا هو تفهم الإسلام، وزيادة

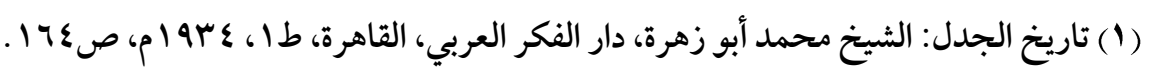

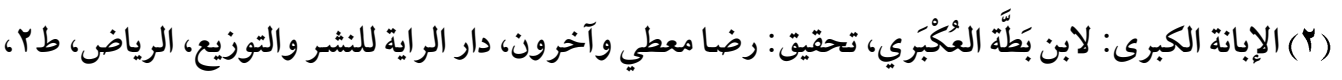

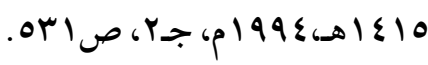


الإيمان وتجديده، وتزكية النفوس، لا أن يكون الجدل همنا، فنضيع الأصول بسببه، فهناك فرق

بين هذا وذاك.

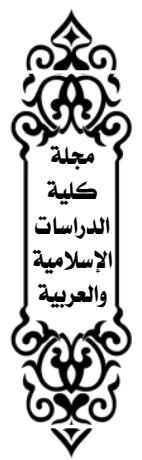




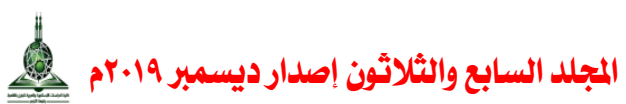

\section{المبحث الثالث}

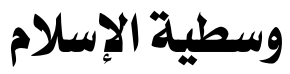

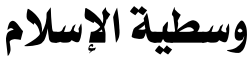

الوسطية هـي إحـدى الخصـائص العامـة للإسـلام، وإحـــى المعـالم الأساسـية التي ميـز

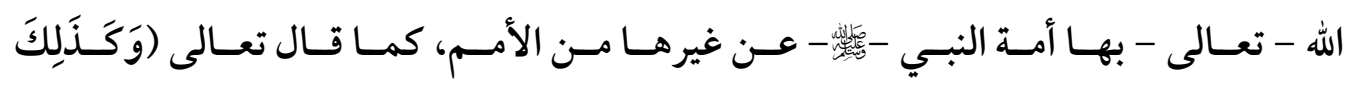

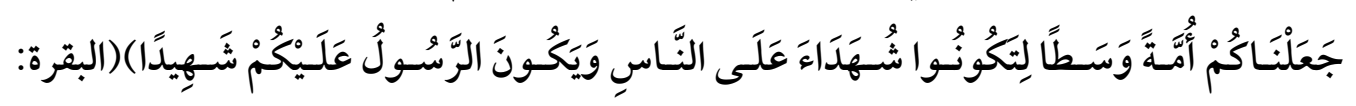

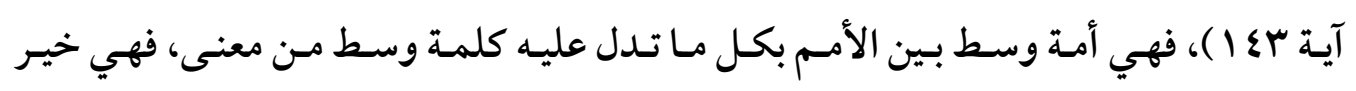

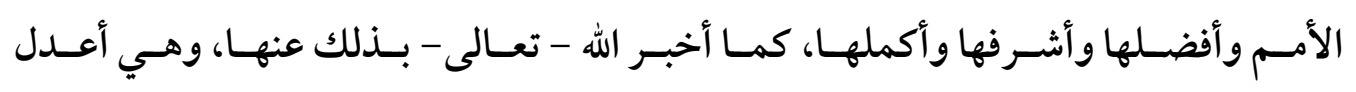
الأمم، ولذلك أعدها الله لتكون شاهدة على الناس.

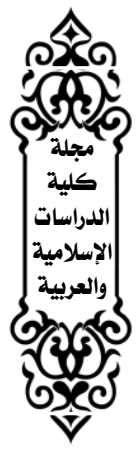

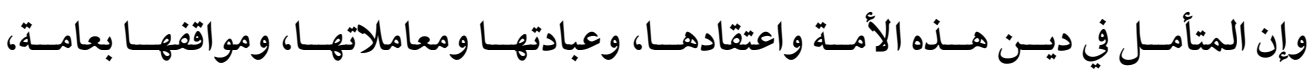

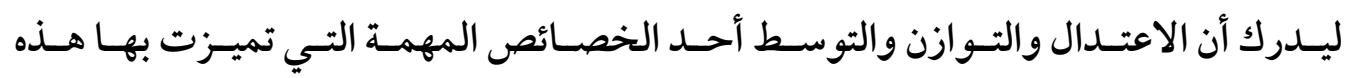

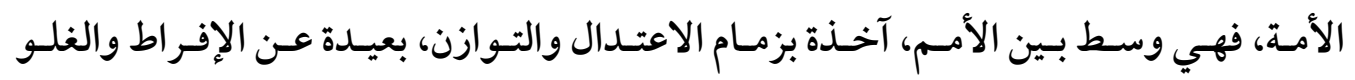
والتفريط والتقصير والجفاء والتشدد.

وهـــه الوسطيَّة ليسـت محصـورةً في جزئيسة مـن الجزئيـات، بـل ولا في ركـن مـن الأركـان،

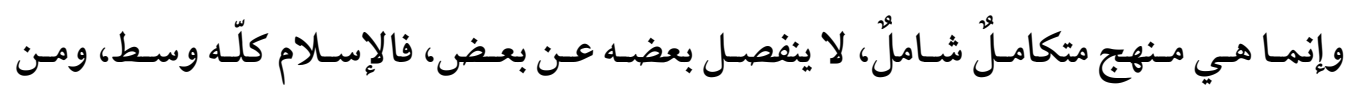

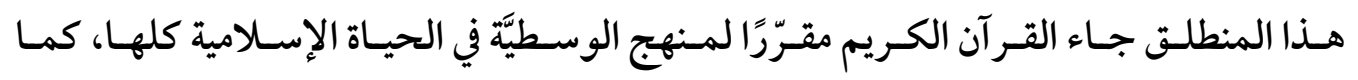

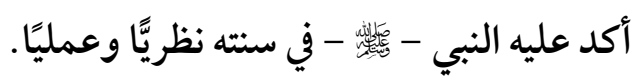

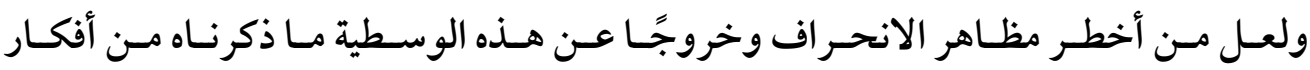

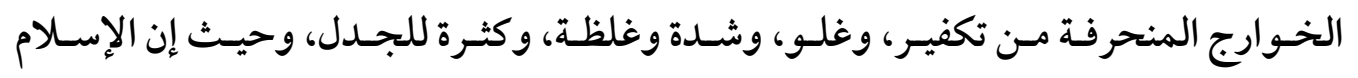
هو دين الوسطية، سنبين موقفه من هذه الأفكار المنحرفة في عجالة سريعة. 
جاء الإسـلام ناهيًا ومشــدةًا على تكفير الآخرين ممن ثبت إســلامهم بيقين في أكثر من نص

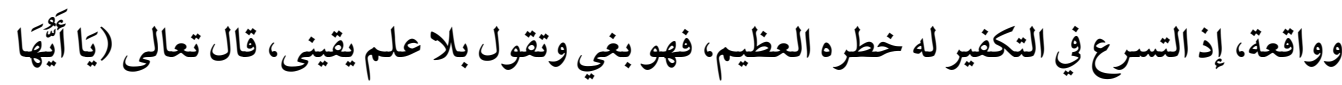

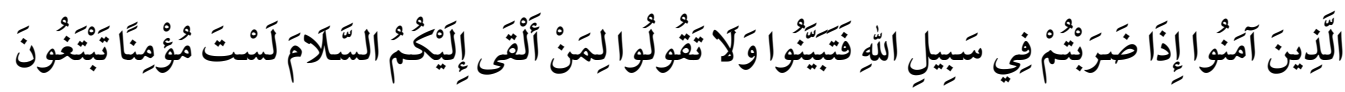

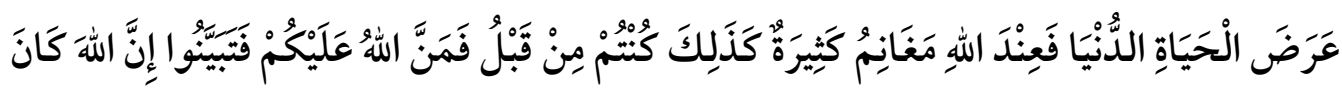

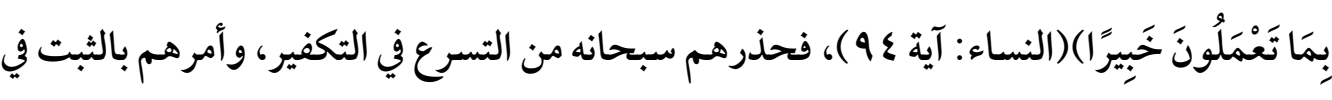

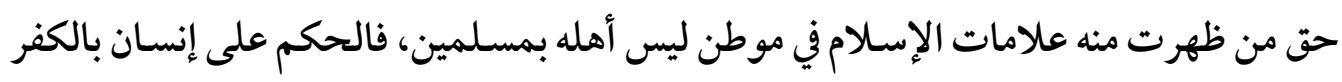

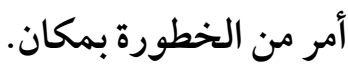

وإذا كانت الحدود تـدْرَأ بالثــبهات، مع أن ما يترتب عليها أقل مما يترتب على النكفير،

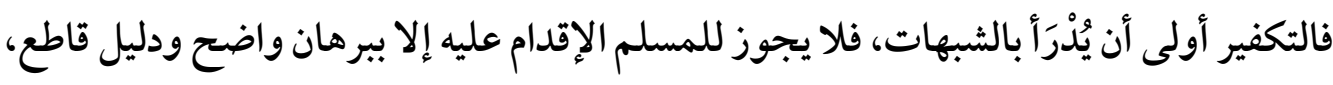

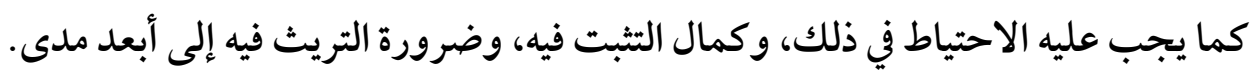
ولخطورة التكفير، وسوء آثاره، واتساع دائرة أضراره، التي تلحق بالفرد والأسرة والمجتمع

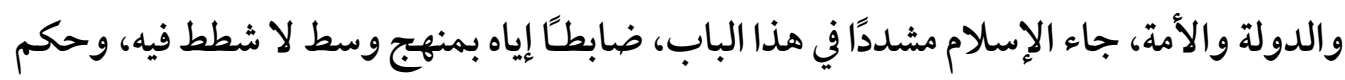

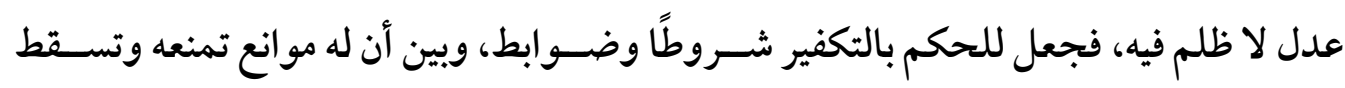

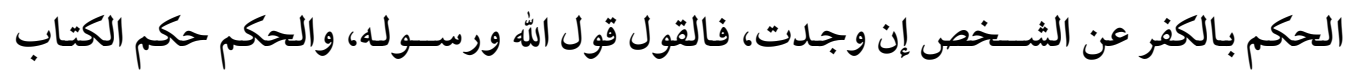
والسنة.

فالتكفير حكم شــرعي، مردّه إلى الله ورسـوله، فكما أن التحليل والتحريم إلى الله ورسـوله،

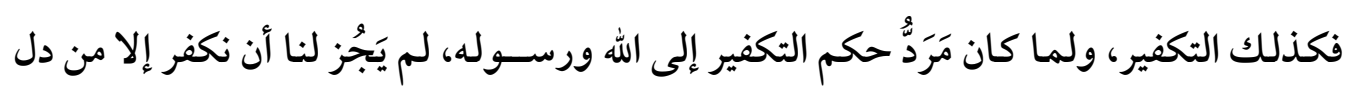

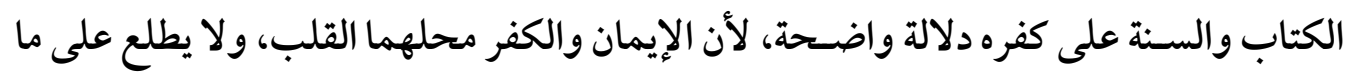

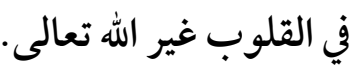


وهذا ما أثار إليه الإمام القرافي عندما قال:" إن كون أمر ما كفرًا، أي أمر كان، ليس من الأمور العقلية بل هو من الأمور الشرعية، فإذا قال الشارع في أمر ما هو كفر فهو كذلك، سواءً كان ذلك

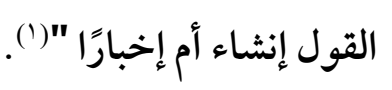

وأكده الإمام الثـهرسـتاني بقوله:" ولأصسـوليين خلاف في تكفير أهل الأهواء مع قطعهم بأن المصـيب واحد بعينه، لأن التكفير حكم شـرعي، والتصـويب حكم عقلي، فمن مبالغ متعصـب لمذهبه كفّر وضلل مخالفه، ومن متساهل متألف لم يكفر "(؟).

فالأصـل بقاء المســلم على إسـلامه حتى يقوم الدليل على خلاف ذلك، فلا يكفي في التكفير مجرد الثـبـهة أو الظن، لِمَا يترتب على ذلك من الأحكام والآثار الخطيرة التي سـبق الحديث

ومن ثم جاءت النصـوص الشـرعية متضـافرة تحذر من الغلو في التكفير تحذيرًا شـديدًا، على وجه الخصوص، وترهب من تعدي حدود الله التي حدّها سبحانه فيه.

ففي السـنة النبوية حذر الرسول - - فئس تكن في صـاحبه فقد رجعت عليه، فعن ابن عمر - رضسي الله عنهما - قال: قال رسـول الله أيما امرئ قال لأخيه: يا كافر، فقد باء بها أحدهما، إن كان كما قال، وإلا رجعت عليه "(r).

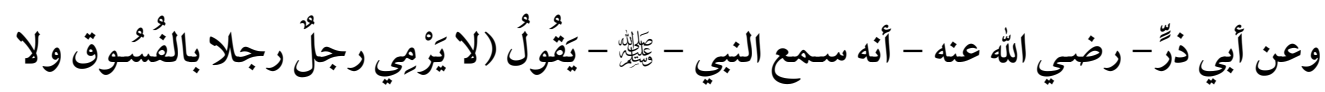

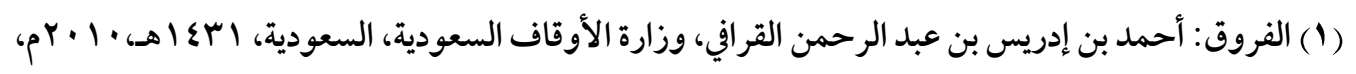
جع، ص101. (10.

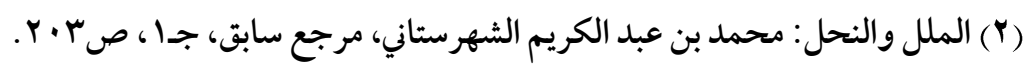

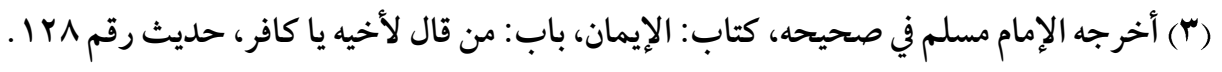




\section{يَرْرِيه بالكفر إلا ارَتَدَّتْ عليه إن لم يكن صاحبُهُ كذلك )('.}

قال الإمام النووي معلقًا على هذا الحديث:" أي فقد رجع عليه تكفيره، فليس الراجع حقيقة الكفر بل التكفير، لكونه جعل أخاه المؤمن كافرًا، فكأنه كفر نفسـه، إما لأنه كفر من هو مثله، وإما لأنه كفر من لا يكفره إلا كافر يعتقد بطلان دين الإسلام، واله أعلم "(().

ومن الآثار الدالة أيضًا على حرمة التكفير لأحد من المسلمين من غير بينة، أن من كفّر مسلمًا

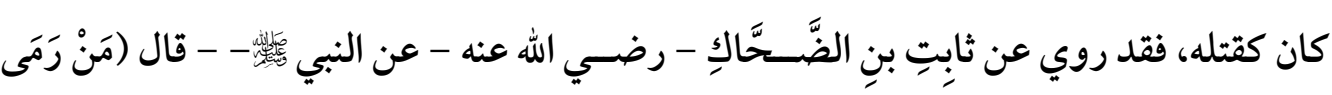

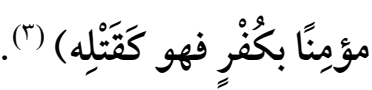

قال البدر العيني - رحمه الله - :" يَعْني: في الحُرْمَة، وقيل: لأن نسبته إلى الكفر المُوجب لقتله كالقتل لأن المتسبب للشيء كفاعله "(s).

فهذه الأحاديث وأمثالها زاجرة للمسلم ومحذرة إياه، حتى لا يتسرع في رمي أخيه بالكفر، لأنه حكم شـرعي، مضـبوط بضـو ابط معلومة من نصـوص الكتاب والسـنة، فلا يصـار إليه بمجرد الهوى والجهل، إذ إن عقوبته وخيمة في الدنيا والآخرة.

قال ابن عساكر بعـــ أن ساق بعضًا مــن النصوص في خطــورة التكــير :" فهذه الأخبـار تمنع

(1) أخرجه الإمام البخاري في صحيحه، كتاب: الأدب، باب: ما يُنْهَى من السِّبَاب واللَّعْن، حديث رقم هـ ـا.

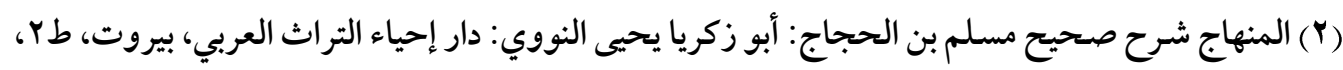
rاهal (ب) أخرجه الإمام البخاري في صسحيحه، كتاب: الأدب، باب: مَنْ كَفَّرَ أخاهُ بغير تأوِيلٍ فهو كما قال، حديث رقم ه.T.

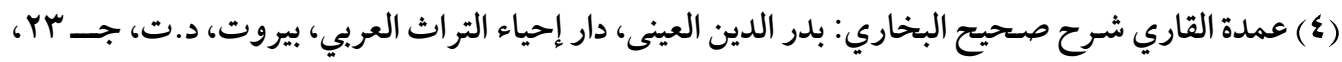
ص. 
المجلد السابع والثلاثّن إصدار ديسمبر 19.0.

مـن تكفير المسلمـين، فمن أقدم على التكفير فقـد عصى سيد المرسلين "((). وقال ابن دقيق العيد في معنى هذه الأحاديث:" وهذا وعيد عظيم لمن أكفر أحدًا من المسلمين وليس كذلك، وهي ورطة عظيمة وقع فيها خلق كثير من المتكلمين، ومن المنسوبين إلى السنة وأهل الحديث لما اختلفوا في العقائد، فغلظوا على مخالفيهم، وحكموا بكفرهم "(؟). ولذا فإننا نرى أن التسرع في الحكم على المسلم بالكفر والخروج من الإسلام يُعد مزلة قدم لا

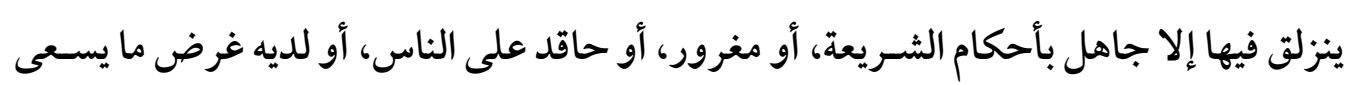
إليه من أغراض الدنيا كالحصول على المال أو السلطة أو الشهرة، أو غير ذلك من متع الدنيا. فعلى هؤلاء الذين يكفّرون ما يشـاؤون من عباد الله، فيخر جونهم من الإسـلام حسبب أهو ائهم واستحســان عقولهم، أن يدركوا خطورة التكفير وما يترتب عليها من فتن وشــرور، وليحذروا من هذا الأمر والخوض فيه بلا علم ولا دليل واضح وبينة كافية. ولما أدرك علماء الإسـلام وأئمة الدين خطورة تكفير المسـلم بغير مكفر شـرعي، سـاروا على هـذا المنهج من الورع والاحتيـاط والحـذر من التكفير، فـأطبقوا على منع التكفير إلا بـدليل

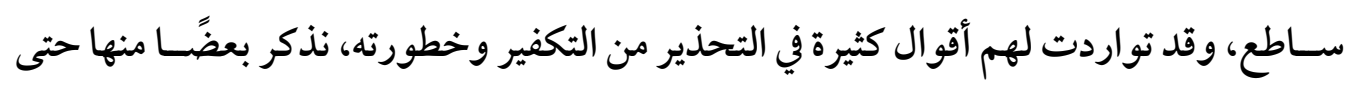
تتضح لنا خطورة هذه المسألة. قال الإمام مالك:" من صــر عنه ما يحتمل الكفر من تسـعة وتسـعين وجهًا، ويحتمل الإيمان

(1) تبيين كذب المفتري فيما نسـب إلى الإمام أبي الحسـن الأشعري: أبو القاسـم علي بن الحسـن المعروف

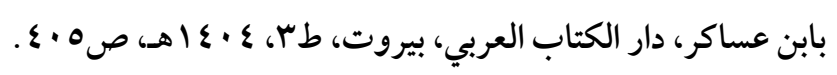

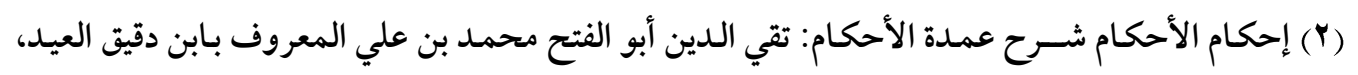

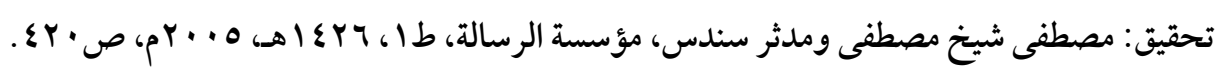


وما أجمل ما صرح به الإمام الغزالي حين قال:" والذي ينبغي أن يميل المحصل إليه الاحتراز من التكفير ما وجد إليه سبيلاً، فإن استباحة الأموال والدماء من المصلين إلى القبلة، المصرحين بقول "لا إله إلا الله محمد رسـول الله" خطأ، والخطأ في ترك تكفير ألف كافر في الحياة أهون من

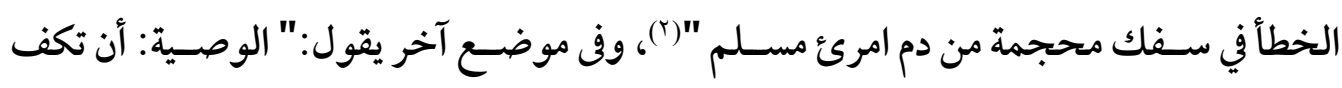
لسـانك عن أهل القبلة مـا أمكنك، ما داموا قائلين: (لا إله إلا الله، محمد رسـول الله)، غير مناقضـين لها ... فإن التكفير فيه خطر، والسكوت لا خطر فيه "(().) وقال الإيجي في المواقف:" لا يجوز الإقدام على التكفير إذ فيه خطر عظيم"((؛). وقال الإمام الشوكاني:" واعلم أن الحكم على رجل مسلم بخروجه عن دين الإسلام ودخوله في دين الكفر، لا ينبغي لمسلم أن يقدم عليه إلا ببرهان أوضح من شمس النهار"، ثم أورد عددًا من الأحاديث التي تحذر من تكفير المسـلم، وقال:" ففي هذه الأحاديث وما ورد موردها أعظم زاجر، وأكبر واعظ عن التسرع في التكفير"(م). هذه هي أهم أقو ال علماء أهل الإســلام، والتي تدل دلالة واضـحة على الاحتياط الشــديد في

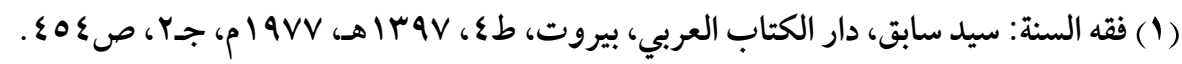

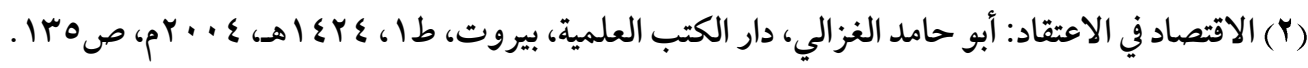

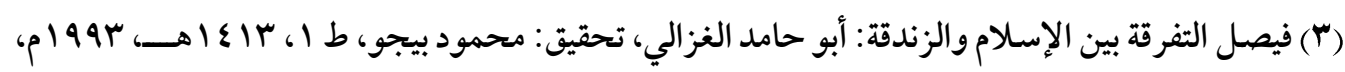
ص (\&) المواقف: عضـــد الـدين عبدـ الرحمن الإيجي، تحقيق: عبـد الرحمن عميرة، دار الجيل، بيروت، طا،

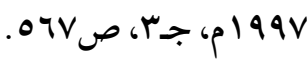
(•) السـيل الجرار المتدفق على حدائق الأزهار: محمد بن علي بن محمد الثـوكاني، تحقيق: محمود إبراهيم

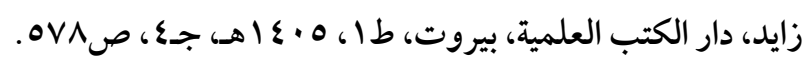


التكفير والاحتراز منه، والتحذير من المسارعة إلى تكفير المسلمين، فالذي يكفر المسلم بدون بينة واضحة ونص صريح، يكون على خطر عظيم.

فمن اشـتبه عليه الأمر فالأولى في حقه الإمسـاك، بل الواجب عليه أن يبقيه على الأصـل الذي هو اليقين، وهو ما أظهره من الإسـلام، وإن كان الثـخص في حقيقة أمره منافقًا يعادى الإسـلام وأهله.

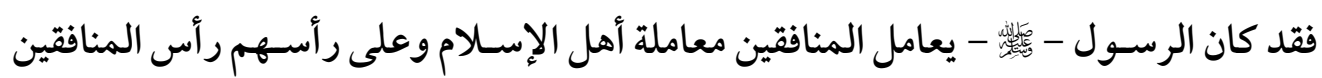

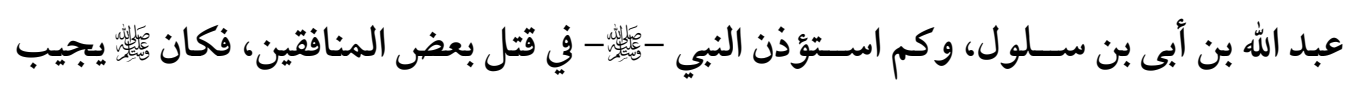
بقوله:" دعه، لا يتحدث الناس أن محمدًا يقتل أصحابه" (1).

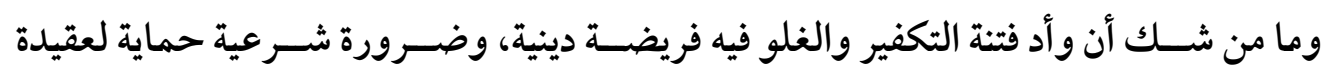
المسـلم من العبث، وصـيانة لحرمة الفرد من الانتهاك، ووقاية للمجتمع من الفتن التي تخرب ولا تعمر، وتفسـد ولا تصــلح، وحماية لشـباب أمتنا من التيارات والأفكار المنحرفة، والأفهام المعوجة. ولأن يحكم المرء لمائة شخص بالإسلام خير له من أن يكفّر مسلمًا، فإن الأحاديث الصحيحة الصـريحة فيها الوعيد لمن كفّر مسـلمًا، كما سـبق بيانه، وليس هناك أحاديث صـريحة - ولو كانت ضـعيفة - تحذر من الحكم بالإسـلام لإنسـان أظهر شـيئًا من شـعائر الإسـلام، وإن كان يُشك في أمره، وهكذا تظهر لنا وسطية الإسلام واضحة تجاه هذا الموضوع الخطير.

(1) أخرجه الإمام البخاري في صحيحه، سورة المنافقون، باب: (يقولون لئن رجعنا إلى المدينة ليخرجن الأعز

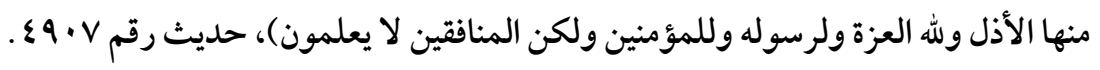


لما كان الله - تعالى - هو الخالق لخلقه، والدين منزل من عنده تعالى، كان سـبحانه أعلم

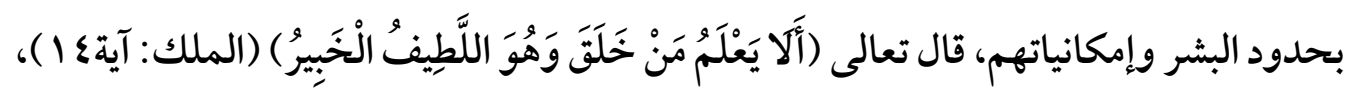
لذا فقد شرع لهم ما يناسبهم ويو افق قدراتهم، ومن ثم جاء الإسلام دينًا سمحًا يسرًا.

وإذا كان الدين الإسلامي بهذا الوضع، دين اعتدال وتوسط وقصد في كل شيء، عُلم أن الغلو فيه، والزيادة على اعتداله، والتشدد في قصده، ضلال عن هديه، وبعد عن مقاصده.

فالغلو في الدين آفة قديمة في جميع الأمم السابقة، وقد كانت هذه الآفة الخطيرة سببًا لهلاكها، من أجل ذلك جاءت الآيات القر آنية والأحاديث النبوية مقررة وسطية الإسلام، ومحذرة من آفة الغلو، ومبينة ما يترتب عليها من أضرار.

وقد جاءت آيتان في القرآن الكريم فيهما النهي عن الغلو بلفظه الصريح، الأولى قوله تعالى (يَا

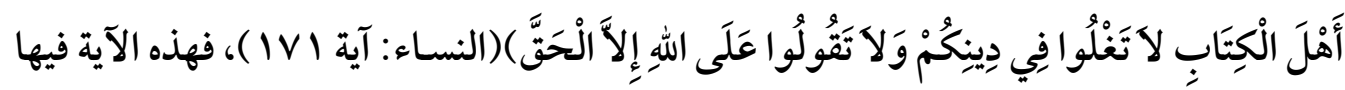
نهي لأهل الكتاب عن الغلو في الدين، وكل خطاب موجه لأهل الكتاب في القرآن الكريم بأمر أو نهي فالمقصود به هذه الأمة، لأنها الأمة المخاطبة بهذا الكتاب أصلاًا، فإذا نهى الله أهل الكتاب عن الغلو فنحن منهيون عنه من باب أولى. قال العلامة عبد الرحمن السـعدي:" ينهى - تعالى - أهل الكتاب عن الغلو في الدين وهو مجاوزة الحد والقدر المشروع إلى ما ليس بمشروع، وذلك كقول النصارى في غلوهم بعيسى عليه الســلام، ورفعه عن مقام النبوة والرســالة إلى مقام الربوبية الذي لا يليق بغير الله، فكما آن 
التقصير والتفريط من المنهيات، فالغلو كذلك "(1). والآية الثانية جاءت في قوله تعالى (قُلْ يَا أَهْلَ الْكِتَابِ لاَتَغْلُوا فِي دِينِكُمْ غَيْرَ الْحَقِّ وَلاَتَتَّبعُوا

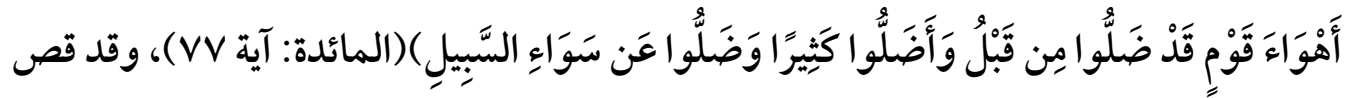
الله - عز وجل - علينا غلو أهل الكتاب، لكي تتعظ أمتنا، وتتجنب سلوك مسالك الغلو. وأما من السُّنة، فقد جاءت أحاديث عن رسول الله - - تحذّ - تحذر الأمة من الغلو، وتبين مصير المغالين وعاقبتهم، منها: قولهـ

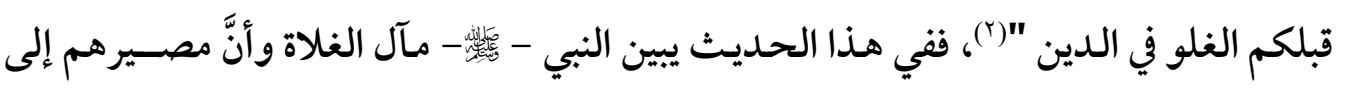
الهلاك كما هلكت الأمم السابقة بسبب الغلو نسأل الله العافية. وقوله الذي هو الغلو والتطرف فيه، والمتنطعون- كما يقول الإمام النووي- هم المتعمقون الغالون المجاوزون الحدود في أقو الهم وأفعالهم (๕) كما جاء في أحاديث أُخَرَ : أن التشـديد على النفس سـبب لوقوع التشــديد من الله تعالى، فقد

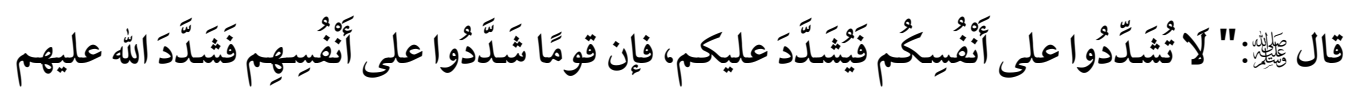
(1) تيسـير الكريم الرحمن في تفسـير كلام المنان: عبد الرحمن بن ناصسر السـعدي، تحقيق: عبد الرحمن

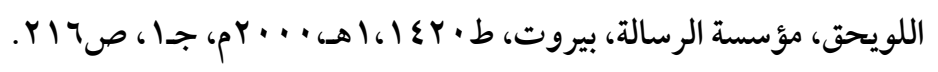

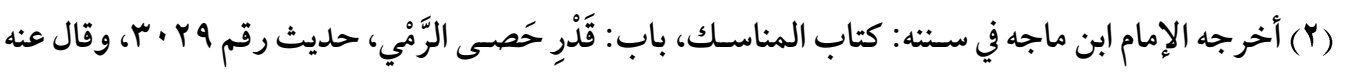

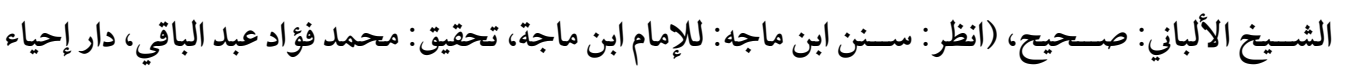

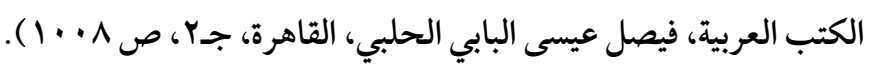

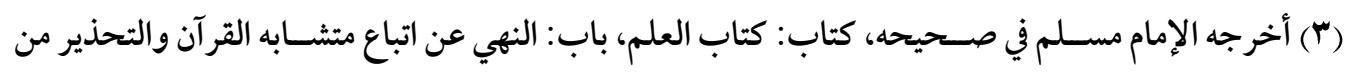

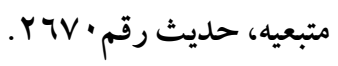

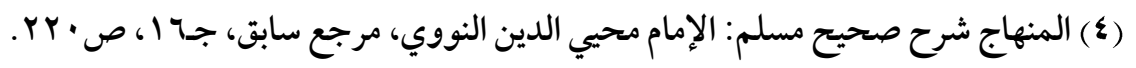


"(()، والتشــديد على النفس هو نوع من أنواع الغلو، بينت الســنة النبوية أن عاقبة صـاحبه إلى الانقطاع، وأنه ما من مشــاد لهذا الدين إلا ويغلب وينقطع عن الاسـتقامة على الدين، كما قال

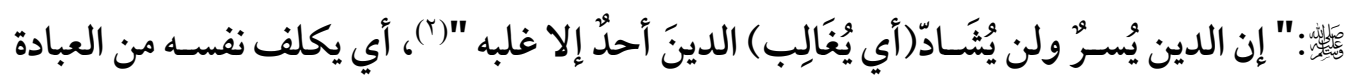

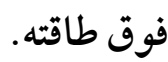

هذه هي بعض الأدلة التي تحذر من الغلو وتبين عاقبته، فالغلو محرم في دين الله تعالى، وهو أمر مذموم تنفر منه الطباع والفطر السـليمةً بـل ويجر ويلات على الإســلام والمســلمين من الإســاءة إليهم وتشـويه صسورتهم، ولذا فإن نسـبته إلى الدين بقول (الغلو الديني) أو (التطرف الديني) تجوز في العبارة لا يصح، إذ الغلو إنما هو في أسلوب التدين لا الدين نفسه، ولذلك جاء

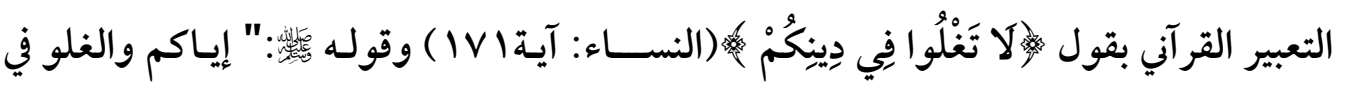

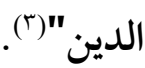

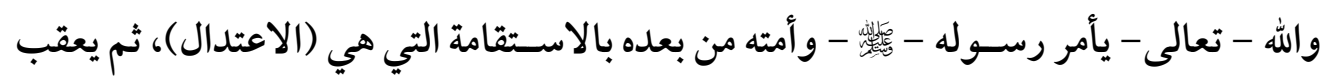

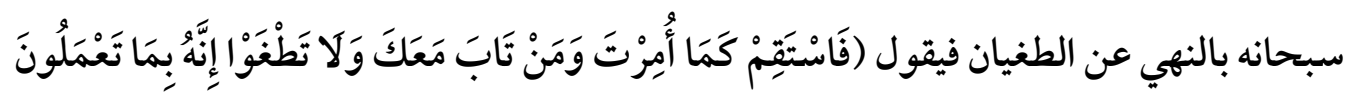

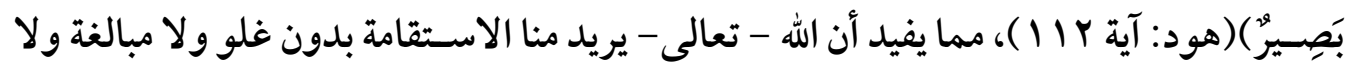
تشديد، وهي الوسطية التي جاء بها الإسلام بين الغلو والتفريط، ولا يمكن أن نسير في ركابها إلا في اتباع سبيل السلف الصالح رضوان الله عليهم. ويجب أن نعلم - كما قال ابن القيم رحمه الله - بأن الله - تعالى - ما أمر بأمر" إلا وللشـيطان فيه نزغتان: إما إلى تفريط وإضاعة، وإما إلى إفراط وغلو، ودين الله وسط بين الجافي عنه والغالي فيه، كالو ادي بين جبلين، والهُدى بين ضـلالتين، والوسـط بين طرفين ذميمين، فكما أن الجافي

$$
\begin{aligned}
& \text { (1) أخرجه الإمام أبو داوود في سننه، كتاب: الأدب، باب: في الحسد، حديث رقم ع •9 ؟ . }
\end{aligned}
$$

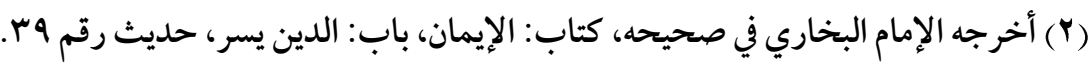

$$
\begin{aligned}
& \text { (r) سبق تخريجه في الصفحة السابقة. }
\end{aligned}
$$




\section{المجلد السابع والثلاثون إصدار ديسمبر 19.}

عن الأمر مضيع له، فالغالي فيه مُضَيِع له: هذا بتقصيره عن الحد، وهذا بتجاوزه الحد "(1). ويؤكد هذا الإمام الحســن البَصْــرِي - رحمه الله - فيقول:" إن دين الله وضـع على الْقَصْــد، فدخل الشيطان فيه بالإفراط والتَّْْصير، فهما سبيلان إلى نار جهنم "(؟). كل هذه الأدلة وغيرها تدل على أن الغلو خروج عن المنهج الوســ الذي وصـــت به أمة الإسلام، بل ومجاوزة للحد، وفعل ما لم يشرعه الله تعالى ولا رسوله كرئ. قال الإمام الطبري:" وأرى أن الله - تعالى ذكُرهُ - إنما وصفهم بأنهم " وسط "، لتوسطهم في الدين، فلا هم أهل غلو فيه، غلو النصـارى الذين غلوا بالترهب، وقولهم في عيسى ما قالوا فيه، ولا هم أهل تقصسير فيه، تقصسير اليهود الذين بدلوا كتاب الله، وقتلوا أنبياءهم، وكذبوا على ربهم، وكفروا به، ولكنهم أهل توسط واعتدال فيه، فوصفهم الله بذلك، إذ كان أحب الأمور إلى الله أوسطها "(r). (") كما أن الغلو بجميع صسوره - وهو مجاوزة الحد الشـرعي - منهى عنه، لأنه تَقَدُّمُ بين يدى الله تعالى ورســوله

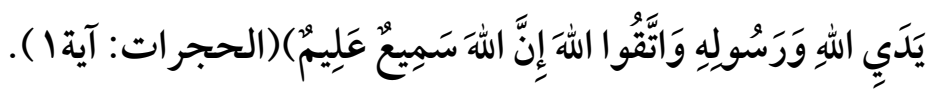

(1) مدارج السالكين: محمد بن أبي بكر ابن قيم الجوزية، تحقيق: محمد المعتصـم باله البغدادي، دار الكتاب

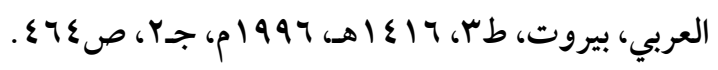
(ז) نوادر الأصول في أحاديث الرسول (: أبو عبد الله الحكيم الترمذي، تحقيق: عبد الرحمن عميرة، دار الجيل، بيروت، د.ت، جا ، صVIT 1. (r) جامع البيان في تأويل القرآن: محمد بن جرير الطبري، تحقيق: أحمد محمد شــاكر، مؤسـســـة الرســالة،

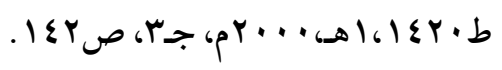




\section{ثالثًاً: موقفه من ظاهرة الشدة والغلظة}

إن يسـر الإسـلام وتيسـيره سـمة من سـماته التي اختلف بها عما سـواه من الأديان، إذ كان من

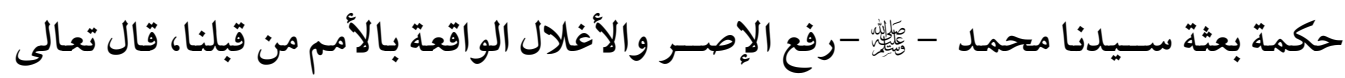

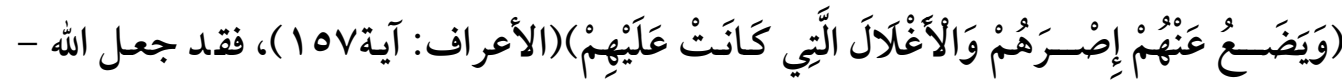
تعالى - شريعة الإسلام سهلة سمحة، وحببها إلى خلقه بذلك.

فالتيسير والسماحة من خصائص الدين الإسلامي، لأن الله - تعالى - أراد لثريعة هذا الدين

أن تكون عامـة للناس، كافة في جميع أنحاء المعمورة، إلى أن يرث الله الأرض ومن عليها، فاقتضى ذلك أن يجعل فيها من اليسر والسـماحة والتخفيف ما يلائم اختلاف الناس وطبائعهم في مختلف الأزمان، وتباين البقاع، حتى يكون تنفيذها بين الأمة ســهلاً ميسـورًا، ولا يتأتى ذلك إلا إذا انتفى عنها الثشدد والمشقة.

ولأن الله جعل هذا الدين هو دين الفطرة، وفي فطرة الإنســان حب اليسـر والرفق والسـماحة، والنفور من الشـدة والعنف والقسـوة، فإن طبيعة البشـر العادية تنفر من التشـديد ولا تحتمله، ولا تصبر عليه، ولو صبر عليه بعضهم لم يصبر عليه عامتهم، وشريعة الدين الإسلامي إنما خاطبت الناس جميعًا، وقد أراد الله - تعالى - عموم هذه الثــريعة ودوامها، ولا يكون ذلك إلا إذا انتفى عنها الشدة والغلظة والقسوة (') ولقد تضـافرت الأدلة من الكتاب والسـنة وآثار الصحابة، وإجماع الأمة على أن التيسير ورفع الحرج أصـل من أصسول الثـريعة الإسـلامية، لذا سـأكتفي هنا بذكر بعضٍ منها: فهناك آيات صرحت بإرادة الله - تعالى - اليسر والتخفيف بهذه الأمة: منها:

(1) مقاصـــ الثــريعة الإسـلامية: الطاهر بن عاشــور التونسـي، تحقيق: محمد الحبيب ابن الخوجة، وزارة

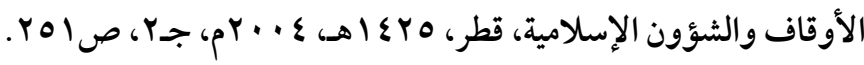




\section{الإجلد السابع والثلاثثن إصدار ديسمبر 19.0.}

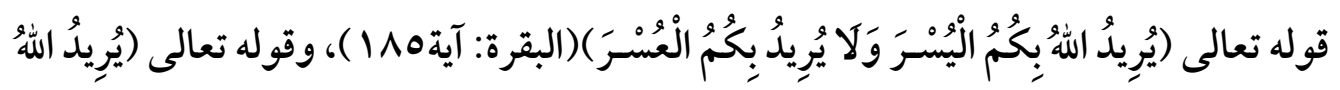

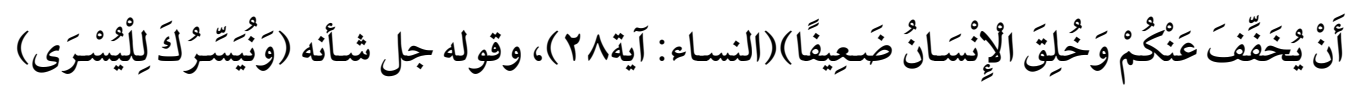

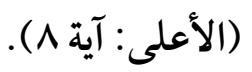

وآيات أخرى صـرحت برفع الحرج والعنت عن الأمة منها: قوله تعالى (مَا يُرِيدُ اللَُّعِبِجْعَلَ

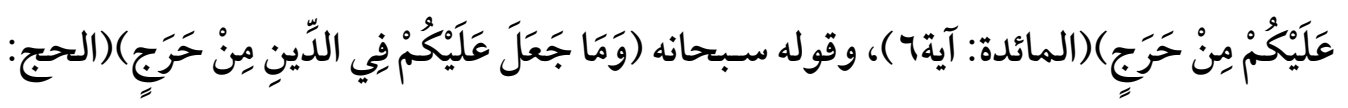

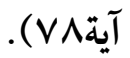

وإذا جئنا إلى السنة النبوية وجدنا فيها أحاديث كثيرة قدصرحت بيسر الدين وسماحته، منها: قوله

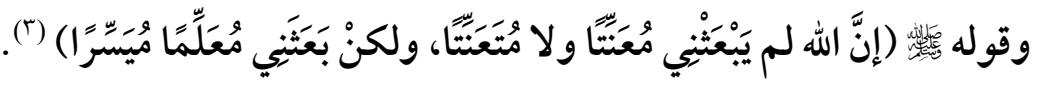
وأحاديث أخرى تأمر بالتيسير وتنهى عن التشـديد والتعمق، منها: قوله

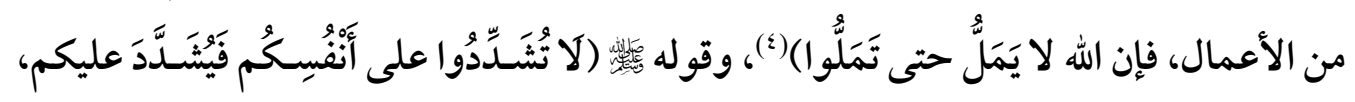

$$
\text { (1) أخرجه الإمام البخاري في صحيحه، كتاب: الإيمان، باب: الدين يسر، حديث رقم ه؟r. }
$$

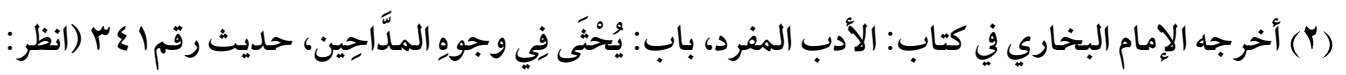

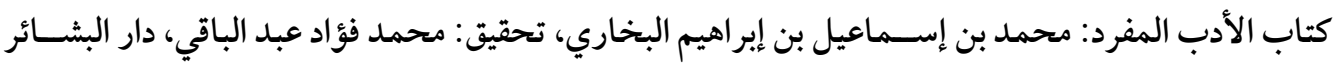

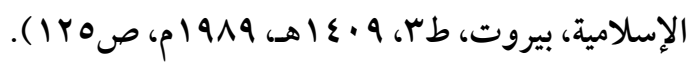

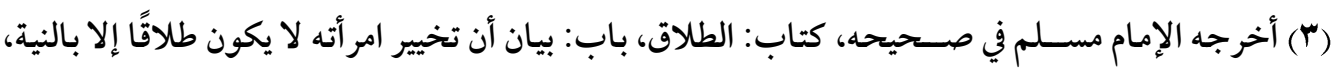

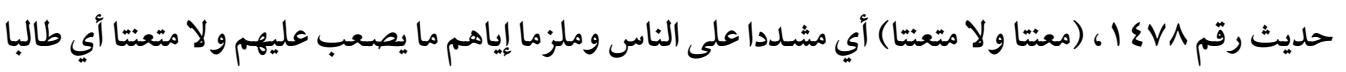

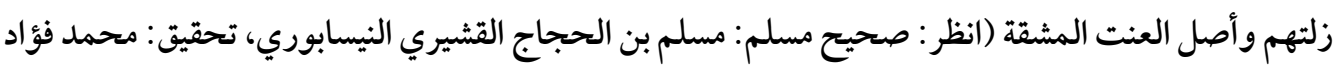

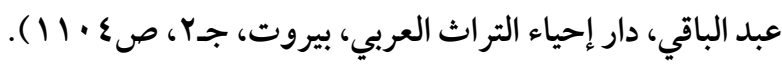
(ع) أخرجه الإمام البخاري في صسحيحه، أبواب التهجد، باب: ما يكره من التشـديد في العبادة، حديث رقم 


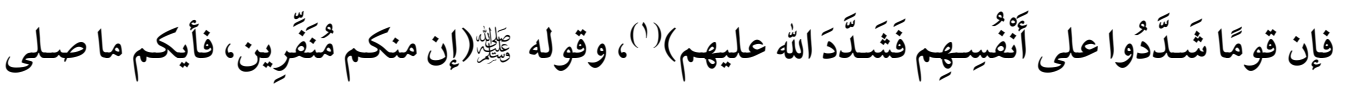

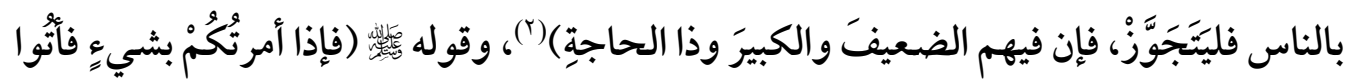

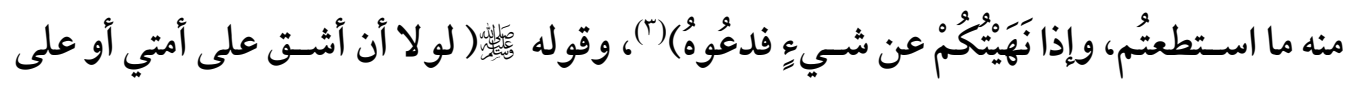
الناس لأمرتهم بالسو اك مع كل صلاة) (؛)

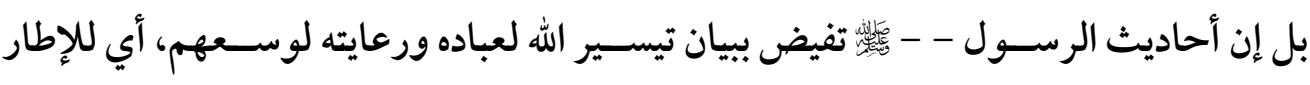
الواقعي الذي يعيشـون فيه، كما تبين أن الخروج عن هذا المبدأ هو بُعد عن طبيعة دين الإسـلام وبُعد عن هديه

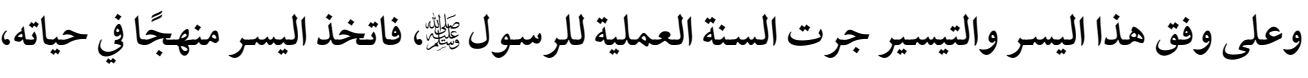
فما خير بين أمرين إلا اختار أيسرهما، وهذا ما أكدته السيدة عائشسة - رضي الله عنها - بقولها

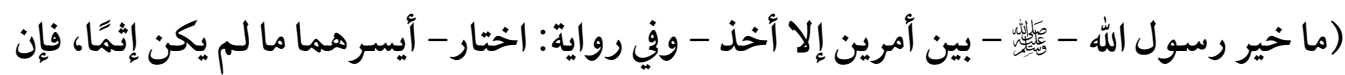
كان إثمًا كان أبعد الناس منه) (•. وقد علق الإمام ابن عبد البر على هذا الحديث فقال:" في هذا الحديث دليل على أن المرء ينبغي له ترك ماعسر عليه من أمور الدنيا والآخرة، وترك الإلحاح فيه إذا لم يضطر إليه، والميل

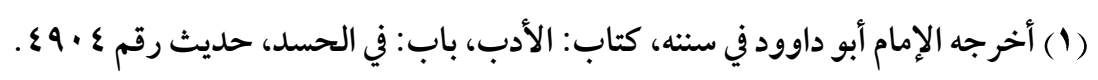

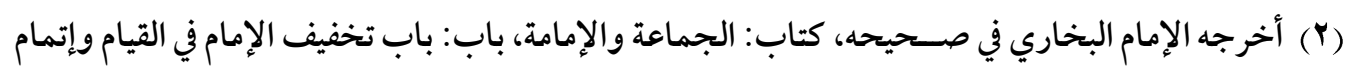

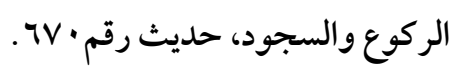

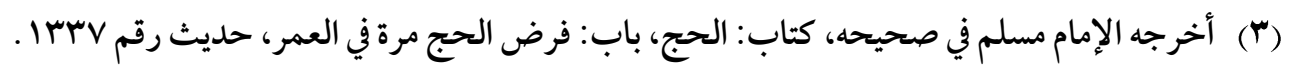

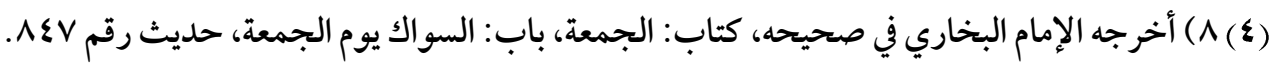
(•) ( ) أخرجه الإمام البخاري في صحيحه، كتاب: المناقب، باب: صفة النبي (، حديث رقم VIrr. 
ولهذا كان

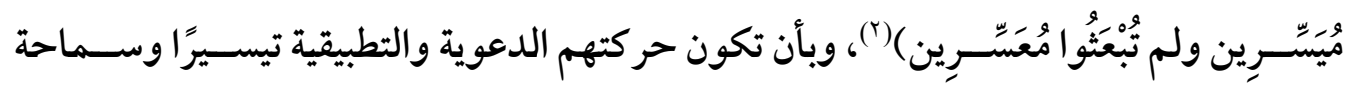

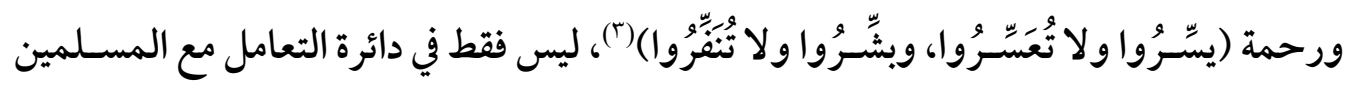
كما يتصــور ذلك بعض من يضــيق قيم الإســلام ويحد من عموميتها، ولكنه مع كل الناس، ولذلك وجه

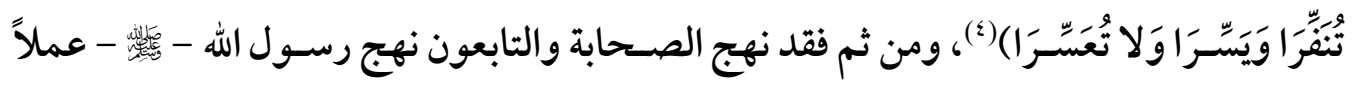
وإرشادًا وتوجيهًا، ولقد كان من طريقهم البعد عن الشدة والتكلف، والأخذ باليسير من الأمر. هذه هي سنة رسول الله وَّل وطريقته: سلوك الطريق الوسط واتباع اليسير، وسلوك غير ذلك -

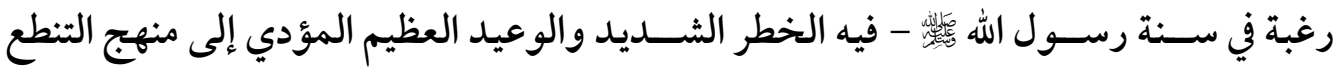
والإفر اط والتفريط، والبعد عن منهج الوسطية الذي تميزت به هذه الأمة من بين سائر الأمم. وبإمعان النظر في النصسوص التي سـقناها من الكتاب والسـنة، وما لم نذكره مما هو في معناها،

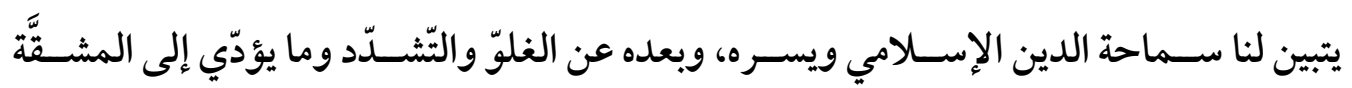
(1) التمهيد لما في الموطأ من المعاني والأسـانيد: أبو عمر يوسـفـ بن عبد البر، تحقيق: مصـطفى بن أحمد

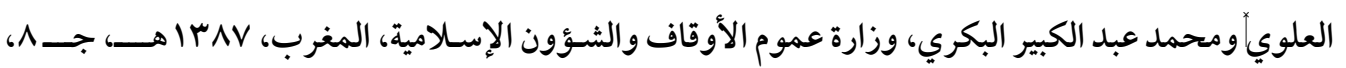
صTะ 1 . (ץ) أخرجه الإمام البخاري في صحيحه، كتاب: الوضوء، باب: صب الماءعلى البول في المسجد، حديث رقم

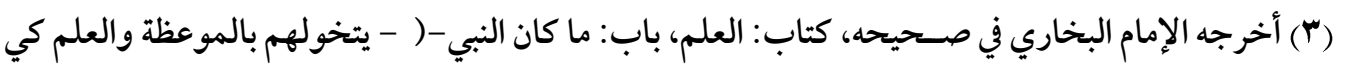

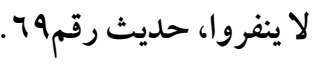
(ع) أخرجه الإمام مسلم في صحيحه، كتاب: الأشربة، باب: بيان أن كل مُسْكِرِ خَمْرُ وأن كل خمرٍ حرام، حديث

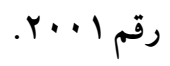


والعسر، كما نستنبط منها أن اليسر والسماحة والرفق وانتفاء الحرج من أكبر مقاصد هذا الدين، وإلى هذا أشـار الطاهر بن عاشـور فقال:" اسـتقر اء الثـــيعة دل على أن السـماحة واليسـر من

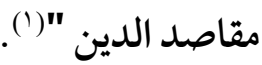

لكن ليس معنى اليسـر والتخفيف والسـماحة في الدين الإسـلامي ترك العمل والتكاسـل عن الطاعات والعبادات، كما ليس معنى التثـديد فيه الأخذ بالأكمل فيها، كلا بل المر اد الالتزام بالتوسط فيها، بلا إفر اط ولا تفريط، فهذا هو منهج الوسطية، وهو صر اط الله المستقيم، فلا ميل إلى جانب الإفر اط والتعمق والتثــديد على النفس وعلى الآخرين، ولا إلى جانب التيسـير الشديد والتساهل الذي يصل إلى حد التحلل والانسلاخ من الأحكام. وهذا لا يعني التفريط والتســاهل والتهاون بحجة أن هذا الدين يســر، وهو ما يبرّر به كثير من المقصّرين والعصاة أفعالهم، فإنَّ تحديد مفهوم اليسر والتخفيف والتّوسعة يرجع إلى الثَّارع لا إلى أهواء الناس ورغباتهم، فالتيسير والتخفيف ورفع الحرج مرتبة عالية بين الإفراط والتفريط، وبين التثــدّد والتنطّع، وبين الإهمال والتضـيع، فالتوسّــ هو منبع الكمـالات، والتّخفيف والسّماحة ورفع الحرج على الحقيقة هو في سلوك طريق الوسط والعدل.

وبهذا ندرك أن هذا الأمر يندرج في منهج الوسـطية، التي هي ســمة من ســمات هذه الأمة، وخاصية من خصائصها، فلن نستطيع أن ندرك معنى الوسطية إلا إذا فهمنا سمة اليسر والتوسعة ورفع الحرج، وألا تصبح الوسطية معنى مفرغًا من حقيقته، وقولاً نظريًا لا وجود له في الواقع. 


\section{رابغًا: موقفه من ظاهرة الجدل واليل إليه}

خلق الله - تعالى - الإنســان ناطقًا مفكرًا، يتوارد عليه من الخواطر والمعلومات ما يجعله مدفوعًا بالضــرورة إلى الإفضــاء بها والإفصــاح عنها، وبناءً على ذلك فالجدل يعد من فطرة الانسـان وخاصسية من خو اصـه التي لا تنفك عنه، لأنه من لوازم النطق والتفكير، فالإنسـان أكثر

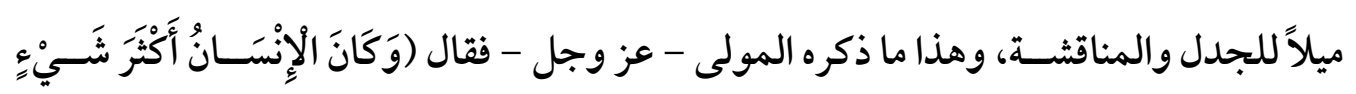

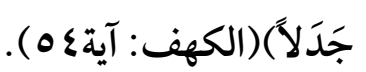

فالجدل لا يمكن أن يخلو منه بشر عنده بيان يعبر به عما يختلج في نفسه من مقاصد وأغراض، بصرف النظر عن كيفية هذا البيان ونوعيته، فهو ضرب من ضروب البيان، وهو قديم في الخليقة، وسـيظل باقيًا إلى يوم الدين، ما دام هناك عقل، ومجتمعات، ومعتقدات، وقضــايا، وتباين في الميول والأهداف، ونفوس بشـرية مجبولة على حب الدفاع عن ذاتها، وتقرير مطالبها، حتى في مواقف القيامة، فإنها لا تتخلى عن هذه النزعة البيانية الإنسانية، كما في قوله تعالى (يَوْمَ تَأْتِي كُلُّْ

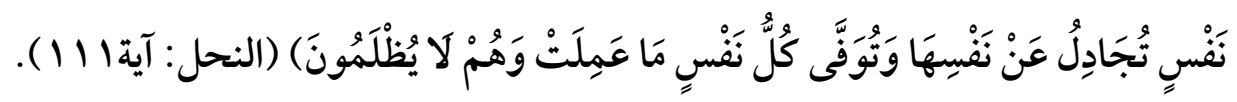
يقول ابن خلدون:" وأما العلوم العقلية التي هي طبيعية للإنسان، من حيث إنه ذو فكر فهي غير مختصــة بملة، بل يوجد النظر فيها لأهل الملل كلهم ويسـتوون في مدار كها ومباحثها، وهي موجودة في النوع الإنساني، منذ كان عمران الخليقة "( (1). والخالق - سـبحانه - يعلم أن من الناس من يبقى مترددًا أو متثـككًا في الحق الذي جاءت به النبوة الخاتمةًأو يكون معاندًا جاحدًا له، مع وضسوح دلائله وصسفاء موارده ومصسادره، ومن ثم

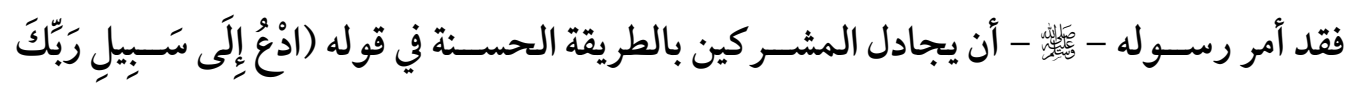

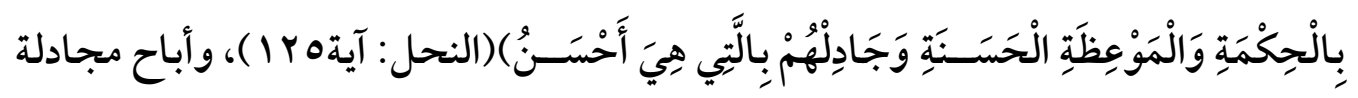

(1) مقدمة ابن خَلدون: عبد الرحمن بن خلدون، دار ابن خلدون، الاسكندرية، د.ت، صهبr. 


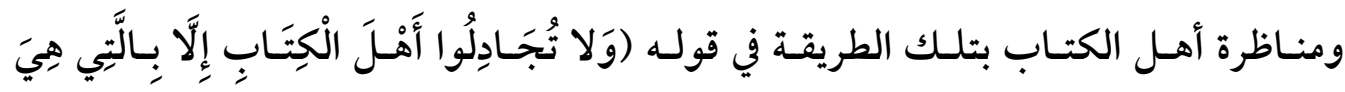

$$
\text { أَحْسنُْ)(العنكبوت: آيةج ع ). }
$$

ومثل هذا من قبيل المناظرة التي تهدف إلى إظهار الحق، وإقامة البرهان على صسحته، وهي الطريقة التي يشـتمل عليها جدل القرآن في هداية الكافرين وإلزام المعاندين، بخلاف مجادلة

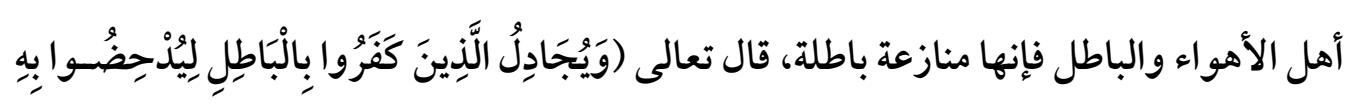

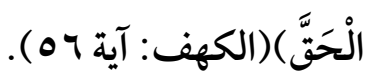

والجدل ســلاح ذو حدين، وقد اشـتبه الأمر على قوم قصـرت علومهم وأفهامهم، فذهبوا ينكرون الجدل والمناظرة ويرون أن ذلك من الأمور الدخيلة على الإسـلام والمسـلمين، فجنى هؤلاء من حيث لا يشـعرون، إذ لم يحرروا أقوالهم، كما لم يفرقوا بين ما يقبله الثــرع وما يرفضـه، وما تقتضــيه ضــرورة الدعوة لدين الله والدفاع عنها بالحجة والبرهان، وبين ما يكون فضولاً من القول وخوضًا في لجج الباطل، بينما يقابل هؤلاء قوم أطلقوا العنان للعقول دون أي قيود أو حدود واعتبروا العقل هو الركيزة الأولى التي تبنى عليها الأحكام ويتفرع عنها الحكم على كل قول أيَا كان مصدره ('). إذن والحالة هذه لابد وأن يكون في الأدلة الشـرعية ما يكشف عن مشـروعية أو عدم مشـروعية الجدل، لأن الإسلام في كل توجيهاته ومعالجاته، إنمَا يتفق مع الفطرة، ويهدي الإنسان فيها للتي

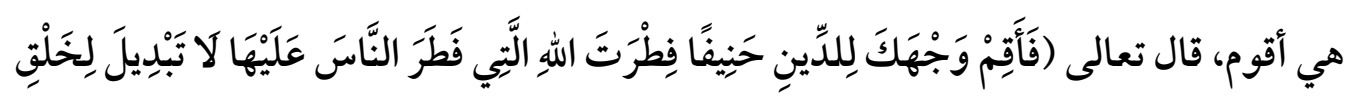

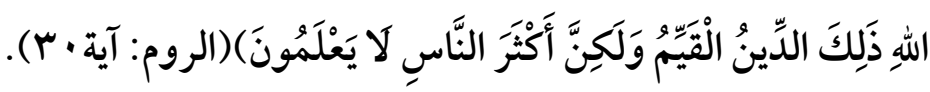
وإن الناظر إلى الأدلة الشرعية التي ورد فيها ذكر الجدل والمجادلة، يجدها على ضربين: الأول: وهو الذي يكون الغرض منه تقرير الحق، وإظهاره بإقامة الأدلة والبراهين على صدقه،

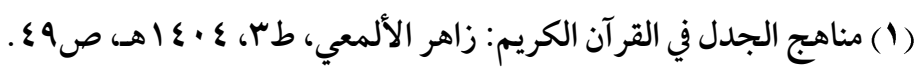




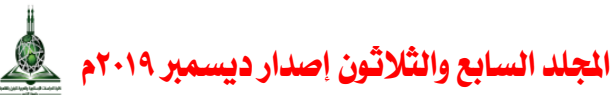

وقد جاءت نصوص الشرع بالأمر به، والحث عليه، والإخبار بأنه طريقة الأنبياء في تبليغ الدعوة

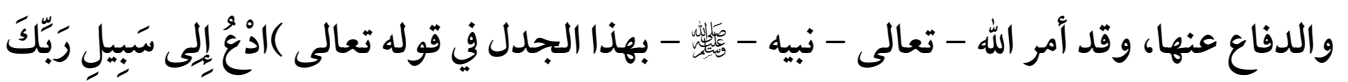

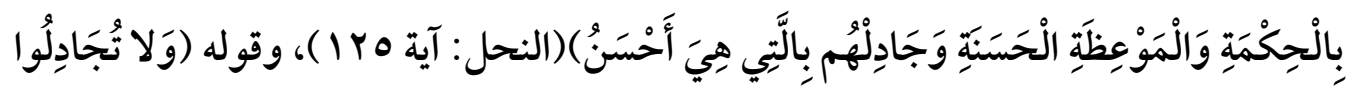

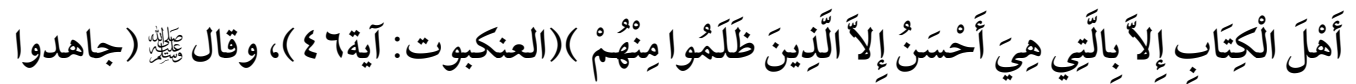

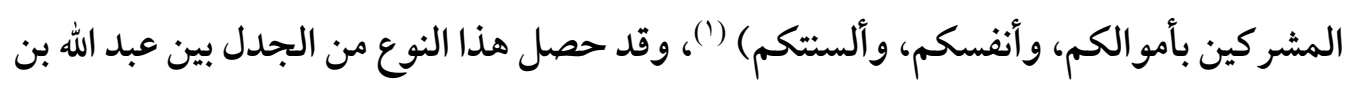
عباس - رضي الله عنهما - وبين الخوارج زمن علي بن أبي طالب - رضي الله عنه - بأمر علي، فأقام عليهم الحجة وأفحمهم، فرجع عن هذه البدعة خلق كثير.

والثاني: هو الذي يكون غرضه تقرير الباطل بعد ظهور الحقّّ، وطلب المال والجاه، وقد جاءت

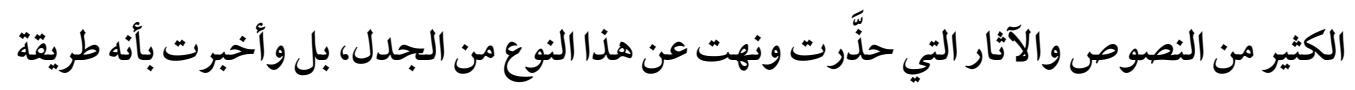
للكفار والمعاندين يريدون به دحض الحق وتقرير الباطل، ومنها: قوله تعالى (وَيُجَادِلُ الَّنِينَ

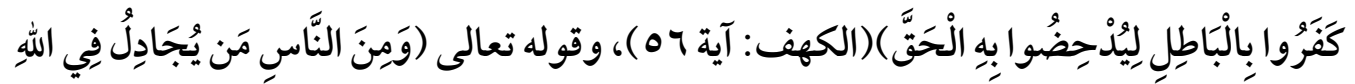

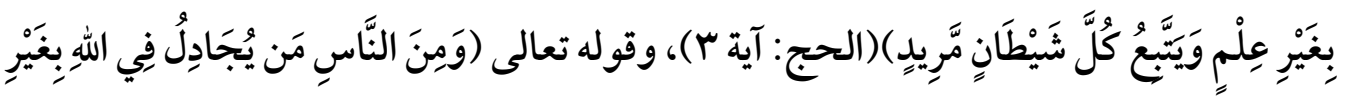

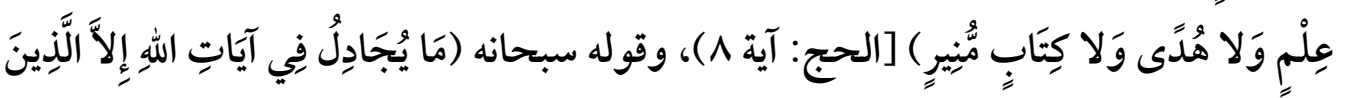

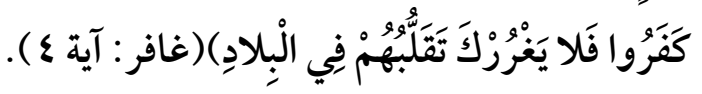
وقد نظر المحققون من أهل العلم إلى هذه النصوص مجتمعة: النصوص التي أمرت بالجدل

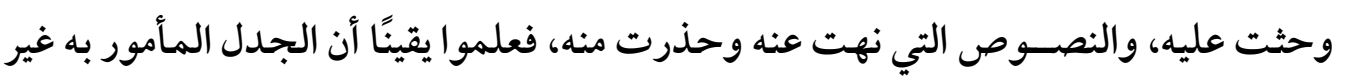
الجدل المنهي عنه، فقالوا: الجدل نوعان: محمود ومذموم، وعلى ذلك تتنزل نصسوص الكتاب

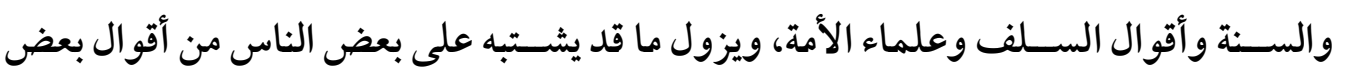

(1) أخرجه الإمام أبو داوود في سننه، كتاب: الجهاد، باب: كراهية ترك الغزو، حديث رقم ع ـ0 Y. 
السلف التي فيها النهي عن الجدل والتحذير منه، ويتبين مقصودهم بذلك (') وتظهر لنا أهمية الجدل من خلال أمر الله - تعالى - باستخدامه في قوله تعالى (وَجَادِلْهُم بِالَّبَّي

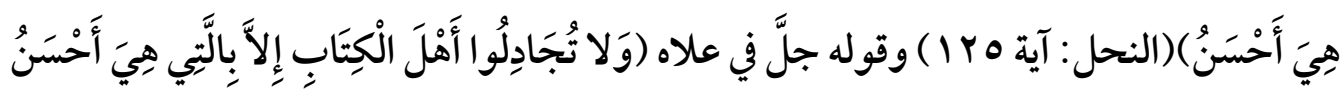

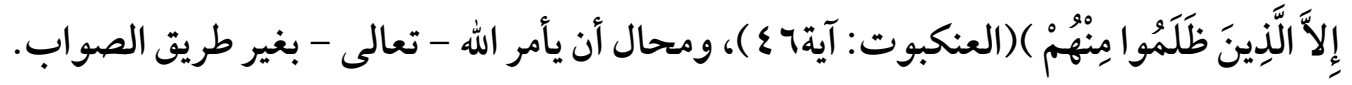

كما تظهر من خلال اسـتخدام الأنبياء - عليهم الصـلاة والسـلام - له في دعوتهم، قال تعالى

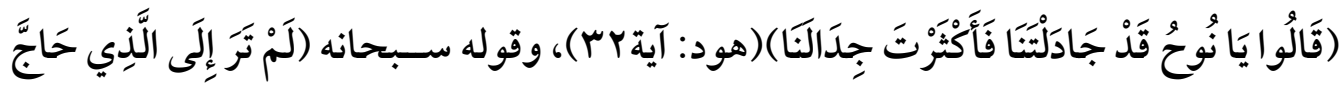

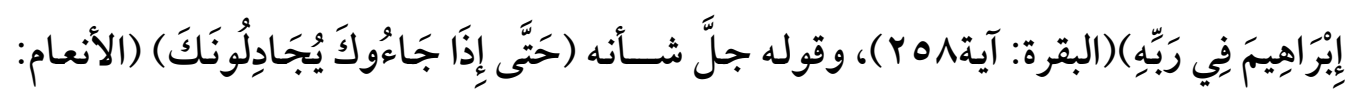

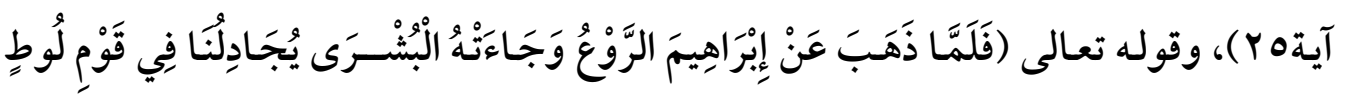
(هود: آية؟ V)، فكل نبي كان يناقش قومه ويجادلهم، ويبين لهم طريق الحق بالأدلة الواضـحة البينة.

كذلك تظهر من خلال أنه أمر فطري جبل عليه الإنسان، يصدر من الصالح والطالح، والكبير

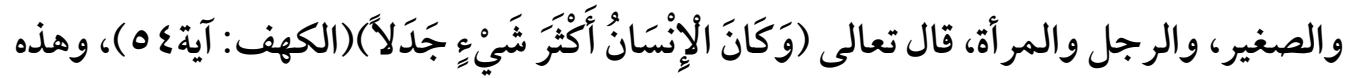
الأمور كلها لابد من ملاحظتها ومر اعتها.

ولهذا بعد أن قسّـــم الإمام الجويني - رحمه الله - الجدل إلى محمود ومذموم، واســدل على النوعين بنصــوص من الكتاب والســنة، قال - عقب اســـلاله على النوع المحمود - :" وهذه الألفاظ عموم في التوحيد والثريعة، وهي - أيضًا - سيرة الرسل - عليهم السلام - مع أممهم،

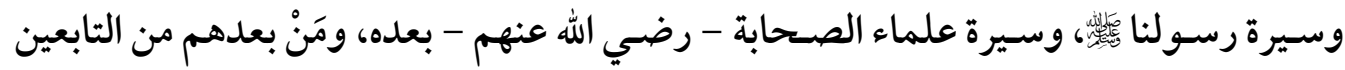
وأتباعهم إلى يومنا هذا، وعليه عادة العقلاء في أديانهم ومعاملاتهم ومعاشر اتهم، ويفزع العقلاء

(1) منهج الجدل والمناظرة في تقرير مسائل الاعتقاد: عثمان على حسن، دار إشبيليا للنشر والتوزيع، السعودية، - b 


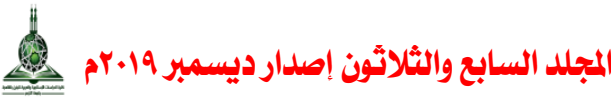

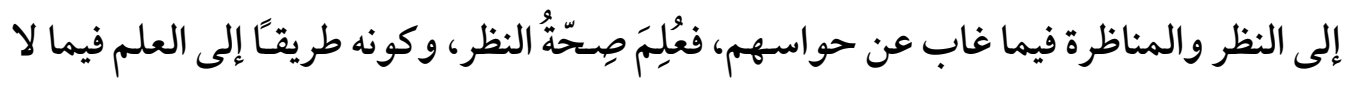
يكون طريق الحس وخبر التواتر طريقًا له " (1).

وما أجمل ما صسرح به الإمام ابن الجوزي عن أهمية معرفة علم الجدل حينما قال:" إن معرفة

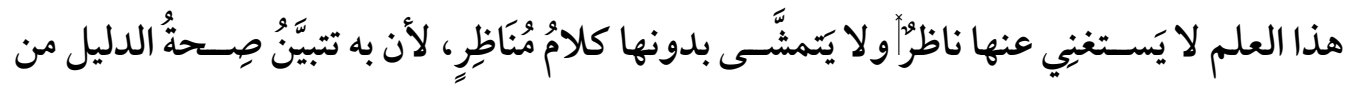

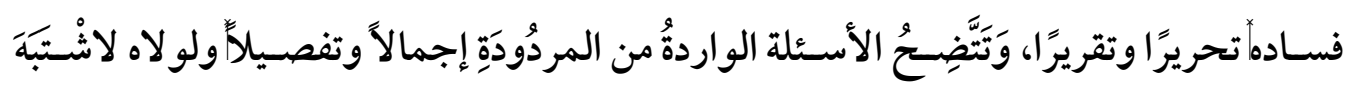

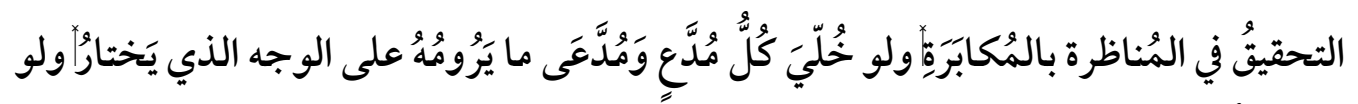

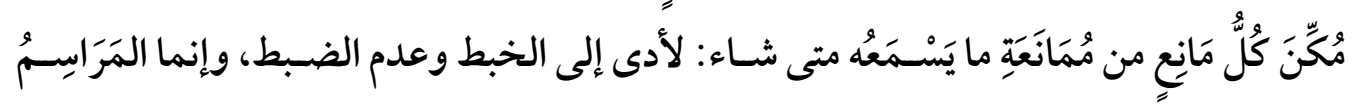

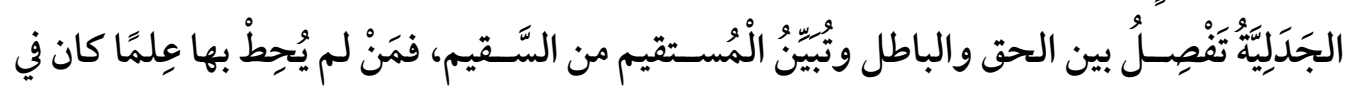

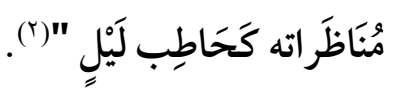

بل إن الإمام ابن حزم - رحمه الله - وصف من يرفض الجدل على العموم، ويدعو إلى إبطاله

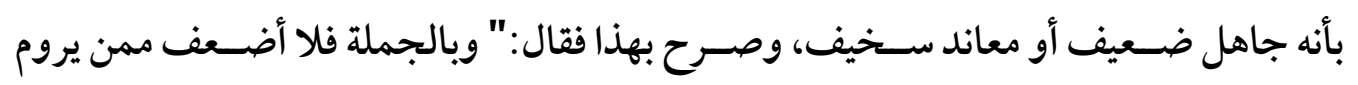

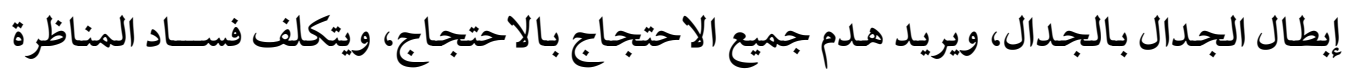

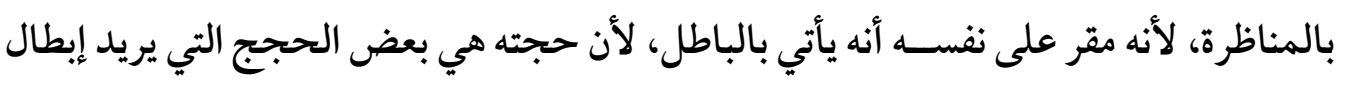

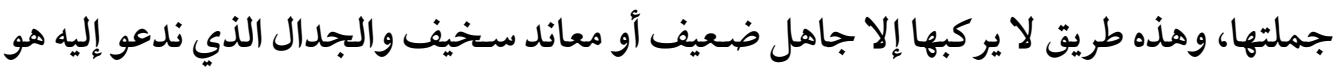
طلب الحق ونصره وإزهاق الباطل وتبينه "(·). ومن خلال هذا العرض يتبين لنا بيانًا لا لُبس فيه أن إنكار الجدل وذمه مطلقًا فيه تعســـ

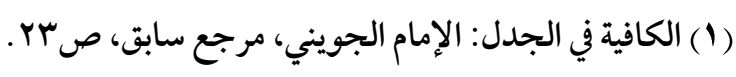

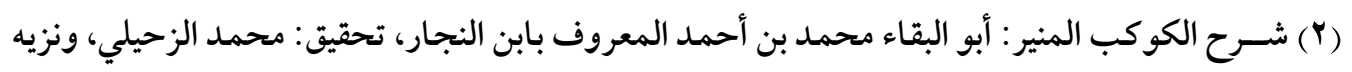

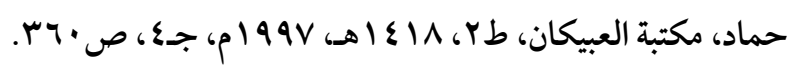

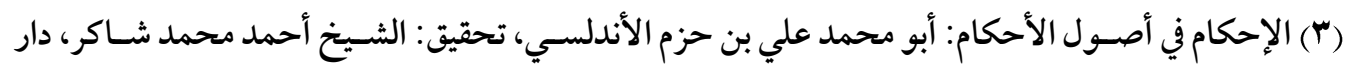

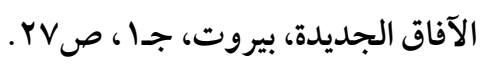


ومكابرة للحق والواقع، وقبوله والدعوة إليه مطلقًا فيه أيضًـــا تعسـف ومكابرة، فإن الجدل تارة يكون بالحق وتارة يكون بالباطل، ودليل ذلك ما ذكرناه من نصــوصٍ من الكتاب والســة تأمر بالجدل وأخرى تنهى عنه، فعلمنا يقينًا أن الجدل الذي تأمر به هذه النصــوص غير الجدل الذي تنهى عنه، إذ لا تعارض بين النصـوص في حقيقة الأمر، فالجمع بين تلك النصـوص الواردة من الكتاب والسـنة وأقوال سـلف الأمة يكون بحملها على ما يناسـبها من حالات الجدل بالحق أو حالات الجدل بالباطل، وهذا هو المنهج الصحيح الذي يؤيده العقل والنقل. وإن من ملامح وسطية هذا الدين وكونه تنـــزيلاً من رب العالمين، أن تعامل بتوازن واعتدال

وواقعية مع طبيعة الإنسـان وما جبل عليه من هذا الجدل الغالب في جنسـاّف فلم يقبله مطلقًا، كما لم يرفضه مطلقًا، فكان أن وجه ربنا - تبارك وتعالى - إلى الجدل وندب إليه، لكن بقدر الحاجة وعند الضرورةًّة وبشكل غير الذي اعتاده الناس وربما مارسوه وعرفوه وفق أهوائهم وشهواتهم| إنه باختصــارً و كما عبر عنه كتاب ربنا - جل شــأنه - بأوجز لفظ وأجزل عبارة (بالتي هي أحسـن)، فهو منهج قائم على الاعتدال، أســــــه الحكمة والموعظة الحســة، وعماده اللين والرفق في غير ضعف، كل ذلك من أجل الوصول للإقناع وإقامة الحجة. 


\section{الغخاثمـــ}

بعد أن انتهيت بحمد الله - تعالى - وتوفيقه من موضسوع هـذا البحث، والذي جاء بعنوان (أفكار الخوارج بين الماضي والحاضر: عرض ومناقشح)، أختم الحديث بذكر أهم النتائج التي توصلت إليها من خلاله، وهي كالتالي:

- الخوارج هم الذين خرجوا على الإمام على - رضسي الله عنه - بعد قبوله التحكيم في موقعة صفين، ومن وافقهم ورأى آرائهم من الناس إلى يوم الدين فهو منهم. - بدأت نشـأتهم بانفصــالهم عن جيش الإمام على رضسي الله عنه، وخروجهم عليه في موقعة صفين بعد التحكيم.

- للخوارج ألقابُّ ومُسمَّيَاتُ كثيرة نسبة لعدة أمور، ومن هذه الأسماء ما يرتضونه ويفتخرون به، كالخوارج والمُحَكَمة والحَرُوْرِية، ومنها ما لا يرتضونه ويرفضونهونه كالمارقة. - تعددت وتثـعبت فرق الخوارج، ومن ثم تباينت أقوال مؤرخي الفرق في تعداد فرقهم، لكن يبقى القدر المتفق عليه بين الجميع أن كبار فرق الخوارج لا يتجاوز ســت فرق، من أشــهرها: الأزارقة، والنجدات، والصفرية، والإباضية، وكثرة الأعداد إنما نشأت من تعدد وانقسام داخل كل فرقة من هذه الفرق.

- هناك عدد من الأصسـول والقواســـم المشـتر كة التي اجتمع عليها عامة الخوارج من أهمها: الخروج على الإمام الجائر، ورفض التحكيم، وتكفير مرتكب الكبيرة.

- تزداد خطورة التكفير وتظهر بصـورة أكثر وضسـوحًا فيما يترتب عليه من آثار، لعل من أهمها: تنفيذ حكم الردة علي صاحبه وهو القتل، ووجوب التفريق بينه وبين امر أثه، وعدم جريان أحكام المسـلمين عليه عند موته، والحكم عليه بـالعذاب واللعنة والخلود في النار، وحبوط عمله، وحرمانه من رحمة الله - تعالى - ومغفرته. 
- لا يحكم على الثــص بالكفر حتى تجتمع فيه جميع شـروط التكفير، من العلم بتحريم هذا ئ المكفر، ومن التعمد والاختيار لفعله، وحتى تنتفي عنه جميع الموانع التي ذكرها أهل

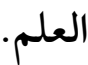

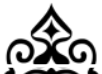

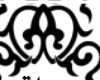

- إن ظاهرة التكفير ليست جديدة على المجتمع الإسلامي، بل إنها تمتد إلى العصر الإسلامي الأول، وتحديدًا إلى ما بعد معركة صِــفِين ونشــوء فرقة الخوارج، والتي يمكن اعتبارها أول حركة تكفيرية ودموية عرفها التاريخ الإسلامي.

- إن ظاهرة الغلو قديمة قدم الرسـالات السـماوية، إذ تمتد جذورها إلى القدم، وهى سـمة في الأمم الماضـية وليسـت خاصـة بهذه الأمة، فكما أنه وجد في هذه الأمة غلو، فقد كان في الأمم الغابرة غلو أيضًا، ومن ثم فإن الغلو ليس خاصًَّا بالمسلمين وحدهم دون سواهم، بل هو منهج له أسبابه وعوامله، التي لا ينفك عنها أي مجتمع بشرى. - الغلو ليس دائمًا دليلاً على خطأ المذهب أو الدين، وإلا لكانت كل الأديان والمذاهب باطلة، لعدم وجود مذهـب أو دين - كما سـبق بيانه - إلا وفي أتباعه غلاة متطرفون، ولذلك فإنه من الغلو والتطرف أيضًا أن نلغي مذهبًا أو منهجًا ما، لمجرد وجود من غلا وتطرف فيه. - مع أن الخوارج كانوا أهل صسيام وصـلاة وتلاوة للقر آن وصـدق في الحديث، لكنهم تجاوزوا حد الاعتدال إلى درجة الغلو، وقد قادهم هذا الغلو إلى مخالفة قواعد الإسلام، بما تُمِليه عليهم عقولهم، فارتكبوا صورًا كثيرة من الظلم والاعتداء والإرهاب بسبب غلوهم في دين الله تعالى. - جنحت فرقة الخوارج نحو الثــدة والغلظة، مبتعدة عن نصــوص الثــرع التي تأمر بالرفق والرحمة وتؤَّد أهميتهما، ضاربة بها عُرض الحائط، ومؤسسة نظامًا جديدًا في التعاملات قائمًا على الغلظة والشدة والعنف، حتى صار التعمق في الدين والتشدد والغلظة فيه من أكبر سماتهم. - الجدل ظاهرة إنسـانية منه ما هو محمود وما هو مذموم، ووصسفه بهذا أو ذاك يتوقف في المقام 


\section{اليجلد السابع والثلاثون إصدار ديسمبر 19.0.}

الأول على الهدف المنشــود من ورائه والأدلة المسـتخدمة لتحقيق ذلك، فإذا كان الهدف منه

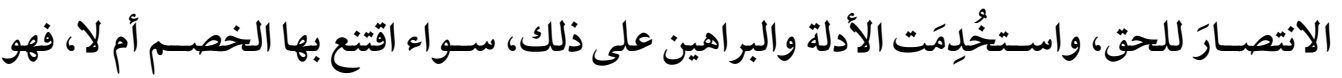
جدل محمود، وما كان بخلاف ذلك فهو جدل مذموم. - الجدل من أهم سـمات الخوارج التي اشتُهروا بها، فكثرة المراء، والإسراف في الجدال، كان من أسباب صرفهم عن تعقّل الحُجج وإدراكها.

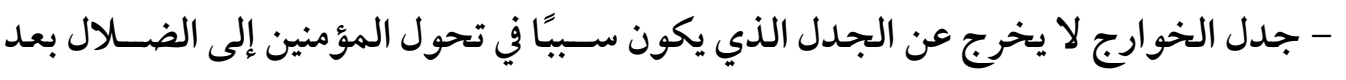

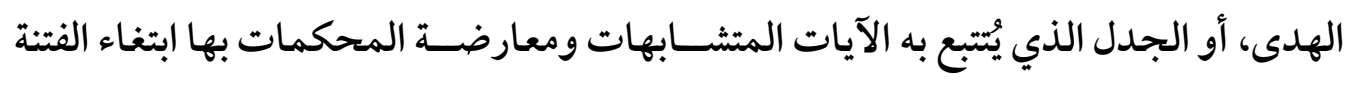

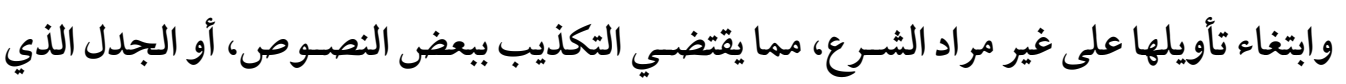

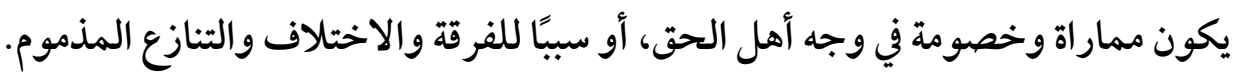
- الوسطية هي إحدى الخصـائص العامة للإسـلام، وإحدى المعالم الأسـاسية التي ميز الله -

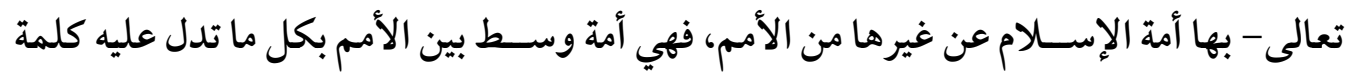

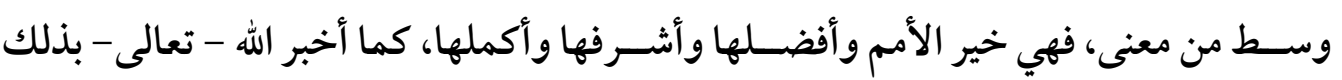
عنها، وهي أعدل الأمم، ولذلك أعدها الله لتكون شاهدة على الناس. - وهذه الوسطيَّة ليست محصـورةً في جزئية من الجزئيات، بل ولا في ركن من الأركان، وإنما

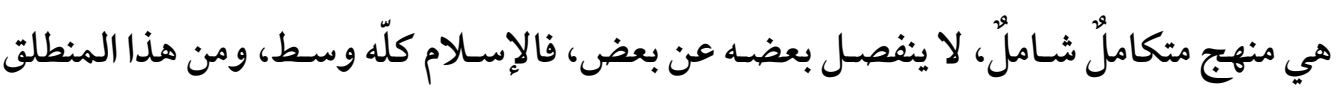

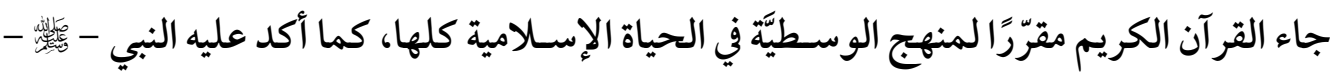
في سنته نظريًّا وعمليًا.

وأخيرًا أحمد الله - عز وجل - على توفيقه إياي للكتابة في هذا الموضــوع، فله الفضـل كله،

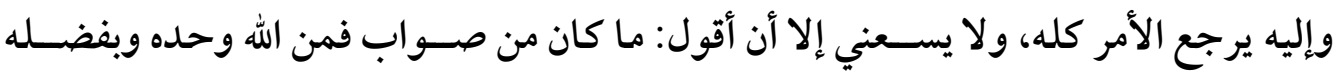

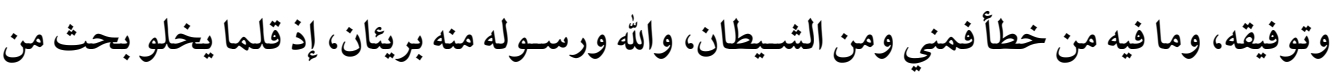




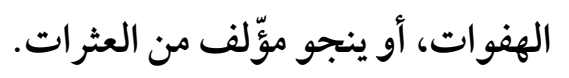

وأسـأل الله العظيم رب العرش العظيم أن يجعله لوجهه خالصَّا، ومن النار منجيَّا ومخلصَّـا،

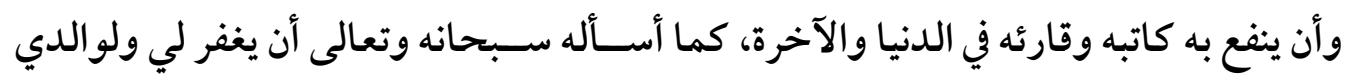




\section{مراجـــع البحث}

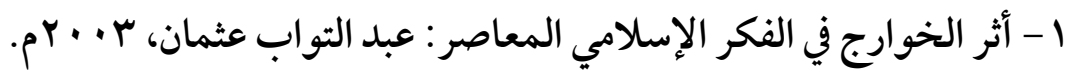
Y - إحكام الأحكام شـرح عمدة الأحكام: تقي الدين أبو الفتح محمد بن علي المعروف بابن

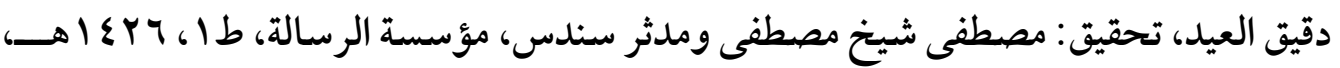
p.o

بـ- أحكام القرآن: أبو بكر الجصــاص، تحقيق: عبد السـلام محمد علي شــاهين، دار الكتب

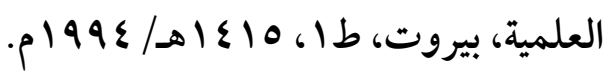
ع - أحكام القر آن: القاضسي محمد أبو بكر بن العربي، تحقيق: علي محمد البجاوي، دار إحياء التراث العربي، بيروت، ط أ.

ه- أســـد الغابة في معرفة الصـحابة: أبو الحسـن علي ابن الأثير، تحقيق: علي محمد معوض،

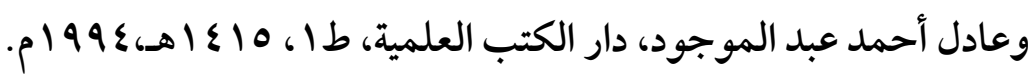

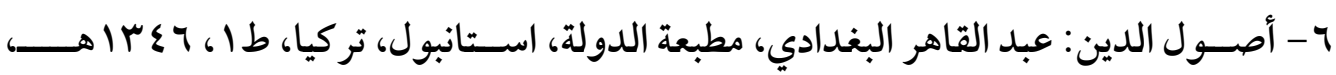
.$\rho 19 r \wedge$ V - اعتقادات فرق المسلمين والمشركين: أبو عبد الله الرازي، تحقيق: علي سـي النشار، دار الكتب العلمية، بيروت، ب + ع اهــ. 1- اقتضــاء الصـراط المسـتقيم: تقي الدين أبو العباس ابن تيمية، تحقيق: ناصـر عبد الكريم

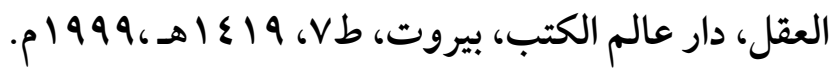
9- الإبانة الكبرى: لابن بَطَّة العُكْبرَي، تحقيق: رضا معطي وآخرون، دار الر اية للنشر والتوزيع،

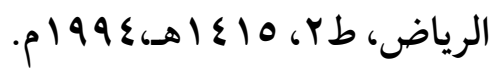
• 1 - الإحكام في أصسـول الأحكام: أبو محمد علي بن حزم الأندلسـي، تحقيق: الثـيخ أحمد محمد شاكر، دار الآفاق الجديدة، بيروت. 1 ا - الاســذكار : ابن عبد البر القرطبي، تحقيق: ســالم محمد عطا، محمد علي معوض، دار 


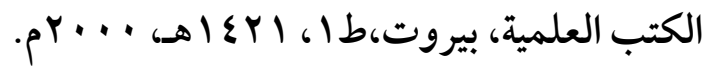

r ا - الإصـابة في تمييز الصـحابة: أبو الفضـل أحمد بن حجر العسـقلاني، تحقيق: علي محمد

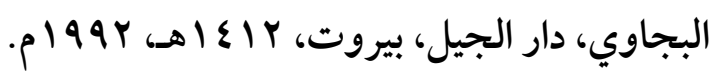

ما - الاعتصـام: إبر اهيم بن موسى الشـهير بالشـاطبي، تحقيق: سـليم بن عيد الهلالي، دار ابن

ع - الأغاني: أبو الفرج الأصفهاني، تحقيق: سمير جابر، دار الفكر، بيروت، طץ.

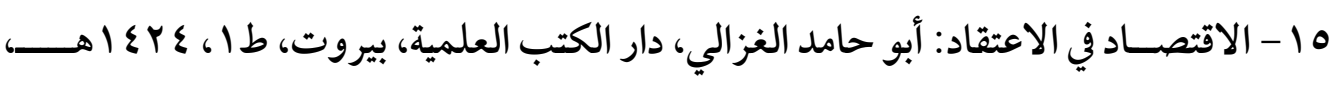

17 - الأم: محمد بن إدريس الثــافعي، تحقيق: رفعت عبد المطلب، دار الوفاء، المنصـورة، . $Y \cdots+16$ IV - الباعث على إنكار البدع والحو ادث: أبو القاسـم شـهاب الدين الدمشـقي المعروف بأبي

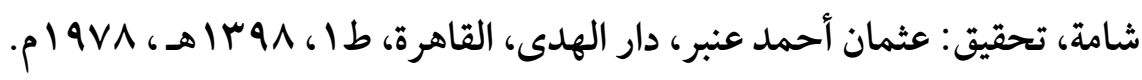
1 1 - البداية والنهاية: أبو الفداء إسـماعيل بن كثير، تحقيق: علي شـيري، دار إحياء التراث

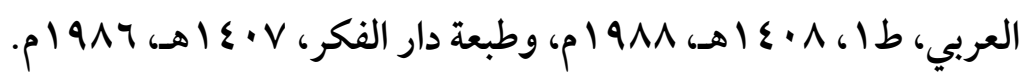
9 19 - البيان والتبيين: للجاحظ، دار ومكتبة الهلال، بيروت، سج \& أهـ. • . - التبصــير في الدين وتمييز الفرقة الناجية عن الفرق الهالكين: أبو المظفر الأسـفراييني،

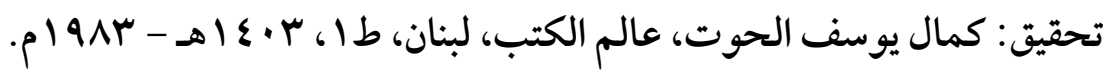
ا ا - التكفير أخطاره وضـوابطه: أبو عبد الله الخطيب، الكلية الأوروبية للدراسـات الإسـلامية،

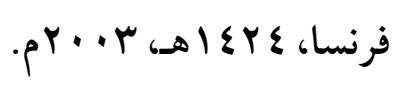

Y Y - التكفير جذوره، أسبابه، مبر راته: نعمان السامرائى، المنارة للطباعة والنشر، بيروت، ط Y، . $19194,01 \varepsilon \cdot 4$ rY - التكفير وضوابطه: منقذ محمود السقار، رابطة العالم الإسلامي. 


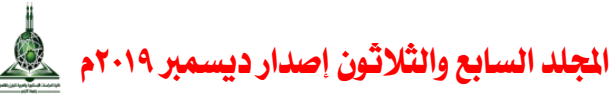

§ Y- التمهيد لما في الموطأ من المعاني والأســانيد: أبو عمر يوسـف بن عبد البر، تحقيق: مصـطفى بن أحمـد العلوياً ومحمـد عبد الكبير البكري، وزارة عموم الأوقـاف والثــؤون

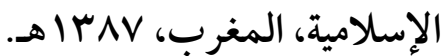

ه P- التببيه والرد على أهل الأهواء والبدع: أبو الحســين المَلَطي العسـقلاني، تحقيق: محمد زاهد الكوثري، المكتبة الأزهرية للتراث، مصر.

جr - الحوادث والبــع: أبو بكر الطرطوشسى، تعليق: على حسـن الحلبى الأثري، دار ابن

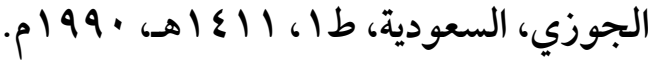
YV - الخوارج (تاريخهم وآراؤهم الاعتقادية وموقف الإســلام منها) : غالب عواجى، رســالة ماجستير، جامعة الملك عبد العزيز، كلية الشريعة، 99 أهـ.

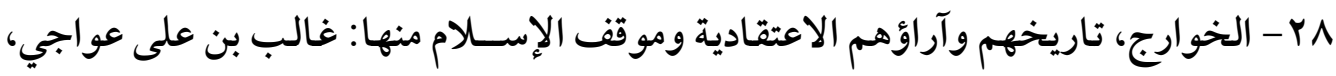

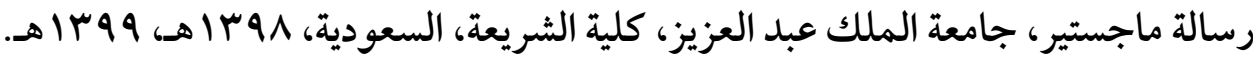
qץ - الخوارج، مناهجهم وأصولهم وسماتهم: ناصر بن عبد الكريم العقل، دار القاسم للنشر،

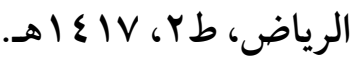
• • إ- السيل الجرار المتدفق على حدائق الأزهار : محمد بن علي بن محمد الشوكاني، تحقيق: محمود إبراهيم زايد، دار الكتب العلمية، بيروت، ط ا، ه ه ـ أهـ. اس الصسحاح: أبو نصـر إســماعيل الجوهري، تحقيق: أحمد عبد الغفور عطار، دار العلم

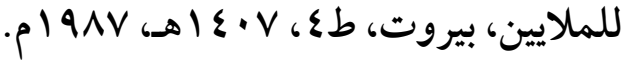
r r الصلاة وأحكام تاركها: ابن قيم الجوزية، مكتبة الثقافة، المدينة المنورة.

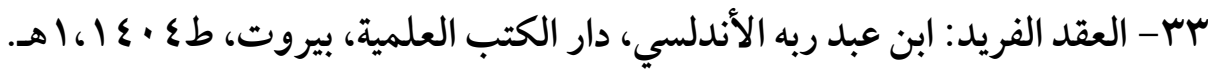
ع ـــ الغلو في التكفير المظاهر ـ الأسباب ـ العلاج: أبو حسام الدين الطرفاوي.

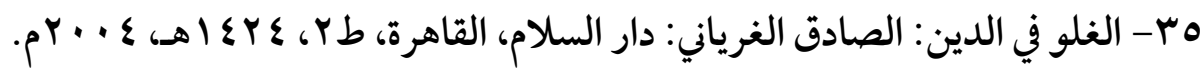
דr - الغلو في الدين: على عبد العزيز الشبل، دار الشبل، الرياض، طا، IV I I اهـ. 


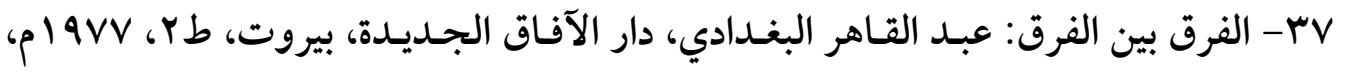
وطبعة، مؤسسة الحلبي للنشر والتوزيع، القاهرة، تحقيق: طه عبد الرؤوف سعد. ^ץ- الفروق: أحمد بن إدريس بن عبد الرحمن القرافي، وزارة الأوقاف السـعودية، السـعودية،

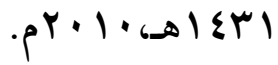

هץ- الفصــل في الملل والأهواء والنحل : أبو محمـد بن حزم الأندلسـي، مكتبة الخـانجي،

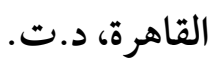

• ع - الكافية في الجدل: الإمام الجويني، تحقيق: فوقية حسـين محمود، طبعة مكتبة عيسىى

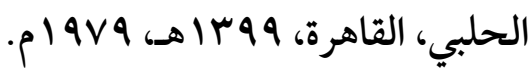

اء - الكامل في التاريخ: أبو الحســن بن الأثير، تحقيق: عمر عبد السـلام تدمري، دار الكتاب

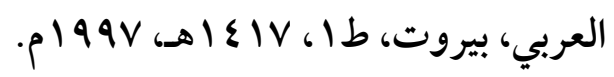

ץ ـ - الكامل في اللغة والأدب: أبو العباس المبرد، تحقيق: محمد أبو الفضل إبر اهيم، دار الفكر

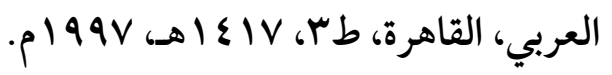
بع - الكامل في اللغة والأدب: أبو العباس بن يزيد المبرد، تحقيق: محمد أبو الفضــل إبراهيم،

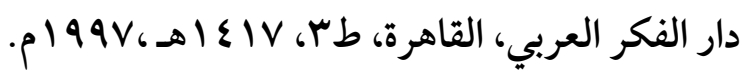
؟ - الكثــاف عن حقائق غوامض التنزيل : الإمام الزمخثــري، دار الكتاب العربي، بيروت، ط ط، V. 1 اهـ. 0ـ - المصباح المنير : أحمد بن محمد الفيومي، المكتبة العلمية، بيروت. جـ - المعجم الكبير: أبو القاسـم الطبراني، تحقيق: حمدي بن عبد المجيد السـلفي، مكتبة ابن تيمية، القاهرة، طY. V - المفردات في غريب القرآن: الراغب الأصــفهانى، تحقيق: صــفوان عدنان الداودي، دار

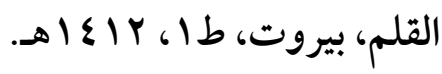
^ـ - المفهم لما أشكل من كتاب تلخيص مسلم: الإمام القرطبي، تحقيق: يوسف علي بدوي 
9 - الملل والنحل: محمد بن عبد الكريم الثــهرســاني، تحقيق: محمد سـيد كيلاني، دار المعرفة، بيروت، ع + ع أهـ. • ه - المثثور في القواعد الفقهية: أبو عبد الله بدر الدين الزركثـي، وزارة الأوقاف الكويتية،

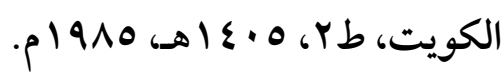

1 ه - المنهاج شـرح صسحيح مسـلم بن الحجاج: أبو زكريا يحيى النووي: دار إحياء التراث

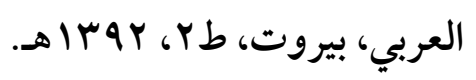
ro - المنهاج شـرح صسحيح مسـلم: أبو زكريا محيي الدين النووي، دار إحياء التراث العربي،

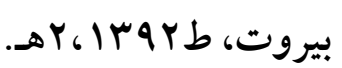

rه - المواقف: عضـــد الدين عبد الرحمن الإيجي، تحقيق: عبد الرحمن عميرة، دار الجيل،

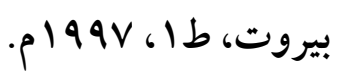
§ه- تاج العروس: المرتضى الزَّبيدي، تحقيق: مجموعة من المحققين، دار الهداية. هـ - تاريخ الجدل: الشيخ محمد أبو زهرة، دار الفكر العربي، القاهرة، طل ـ ع به ام.

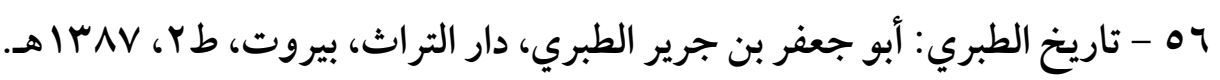
OV - تاريخ المذاهب الإسلامية: الشيخ محمد أبو زهرة، دار الفكر العربي، القاهرة. 1ه - تاريخ المذاهب الفكرية: الشيخ أبو زهرة، دار الفكر العربي، القاهرة.

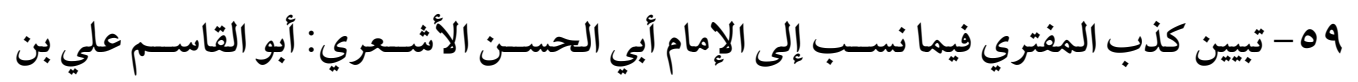
الحسن المعروف بابن عساكر، دار الكتاب العربي، بيروت، طس، ع • ـ اهـ. • . - تفسـير القرآن العظيم: أبو الفداء إســماعيل بن عمر بن كثير تحقيق: ســامي بن محمد

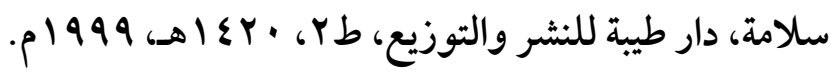
الج - تفسـير القرطبي: الإمام شـمس الدين القرطبي، تحقيق: أحمد البردوني وإبر اهيم أطفيش،

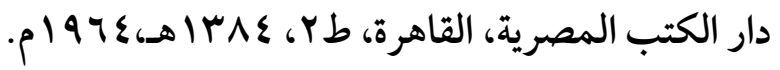


rآ- تلبيس إبليس: عبد الرحمن بن علي أبو الفرج بن الجوزي، تحقيق: الســـد الجميلي، دار

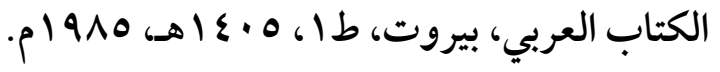
ها - تهذيب اللغة: محمد بن أحمـد بن الأزهري، تحقيق: محمد عوض مرعب، دار إحياء التراث العربي، بيروت، ط| + . . ب، ام.

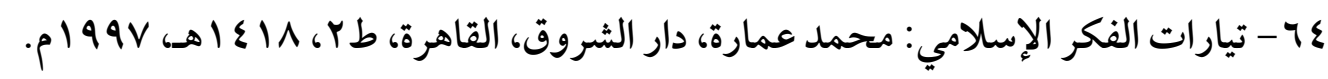
هـ - تيسير الكريم الرحمن في تفسير كلام المنان: عبد الرحمن بن ناصر السعدي، تحقيق: عبد

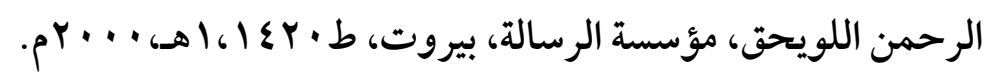
צج- جـامع البيان في تأويل القرآن: محمـد بن جرير الطبري، تحقيق: أحمـد محمـد شـــاكر،

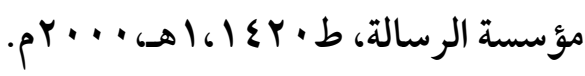
VIV - جمهرة أنسـاب العرب: لابن حزم الأندلسـي، تحقيق: مجموعة من العلماء، دار الكتب

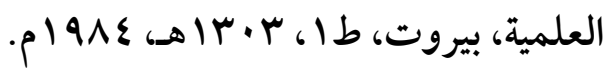
^^ף- حماية المجتمع المسـلم من الانحر اف الفكري: مجلة البحوث الإســلامية، السـعودية،

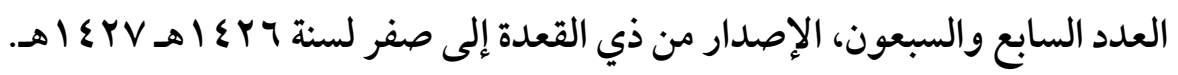
9 4 - روح المعاني: شهاب الدين الألوسي، تحقيق: علي عبد الباري عطية، دار الكتب العلمية،

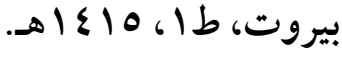
• - - روضـة العقلاء ونزهة الفضهلاء: أبو حاتم محمد بن حبان الدارمي، المحقق: محمد محي الدين عبد الحميد، دار الكتب العلمية، بيروت.

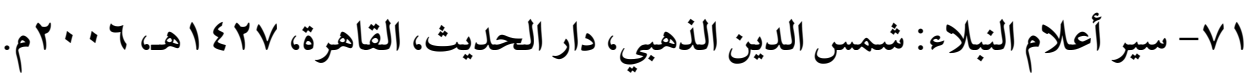

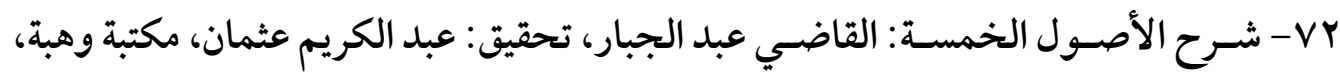

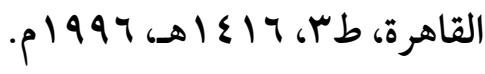
rV- شـرح الكوكب المنير : أبو البقاء محمد بن أحمد المعروف بابن النجار، تحقيق: محمد

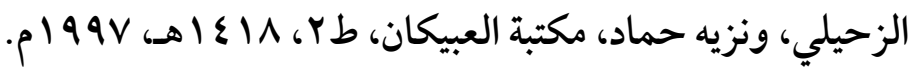


ع V- ظاهرة الغلو في التكفير : يوسف القرضاوى، مكتبة وهبة، القاهرة، ط || | | ، اهـ، • 99 |م. ه V- ظاهرة الغلو والتكفير : الأصــول، والأسـباب، والعلاج: ناصـر بن عبد الكريم العقل، دار كنوز إشبيليا، الرياض، هY \& أهـ. TV- عمدة القاري شرح صحيح البخاري: بدر الدين العينى، دار إحياء التراث العربي، بيروت، د.ت.

-VV

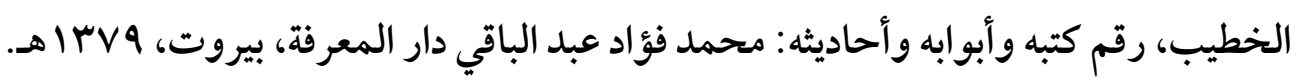
1 - فتح الباري شـرح صسحيح البخاري: أحمد بن حجر العسـقلاني، تحقيق: محمد فؤاد عبد الباقي، ومحب الدين الخطيب، دار المعرفة، بيروت، و 9 I ا هـ. 99- فتح القدير : الإمام محمد بن علي الثــوكاني، دار ابن كثير، دار الكلم الطيب، دمشـق،

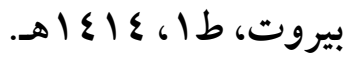
• 1 - فجر الإسلام: أحمد أمين، دار الكتاب العربي، بيروت، 979 (م)، ط. 1. ا 1- فرق معاصـرة تنتسـب إلى الإســلام وبيان موقف الإســلام منها: غالب عو اجي، المكتبة

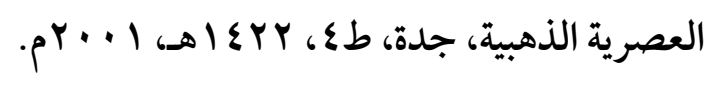

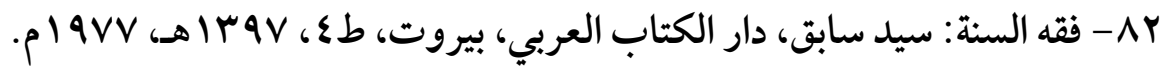
میر- فيصـل التفرقة بين الإسـلام والزندقة: أبو حامد الغزالي، تحقيق: محمود بيجو، طال، . ع^- كتاب الإيمان: أبو عُبيد القاســم بن سـلالّم، تحقيق: محمد نصــر الدين الألباني، مكتبة

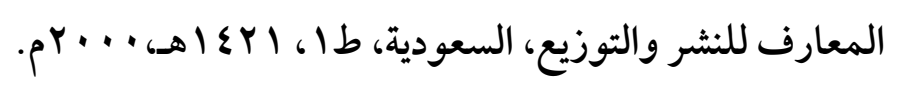
هی- كثــف الأســـرار: علاء الدين البخاري، تحقيق: عبد الله محمود محمد عمر، دار الكتب

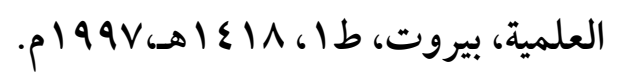

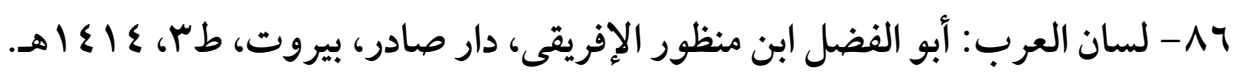


NV مجموع الفتاوى: شـيخ الإســلام ابن تيميه، تحقيق: عبد الرحمن بن محمد بن قاســم، مجمع الملك فهد لطباعة المصحف الشريف، المدينة النبوية، السعودية ، 17 ـ | هـ/ 1990 ام. 11- مدارج الســالكين: محمد بن أبي بكر ابن قيم الجوزية، تحقيق: محمد المعتصــم باله

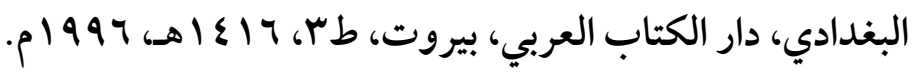
ه1 - مِرْعَاة المَفَاتِيحِ شرح مشكاة المصابيح: أبو الحسن المبار كفوري، إدارة البحوث العلمية

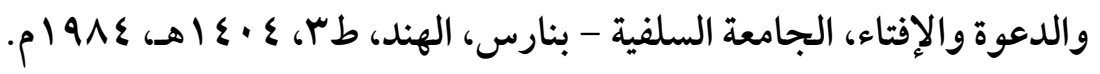

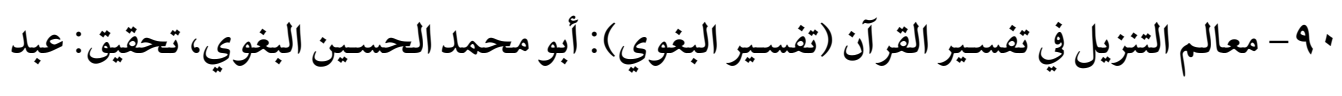
الرزاق المهدي، دار إحياء التراث العربي، بيروت، ط ا، ، بع أهـ. 19 - معاني القرآن وإعرابه: أبو إسحاق الزجاج، تحقيق: عبد الجليل عبده شلبي، عالم الكتب،

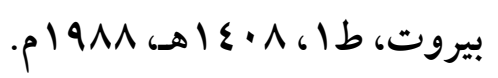

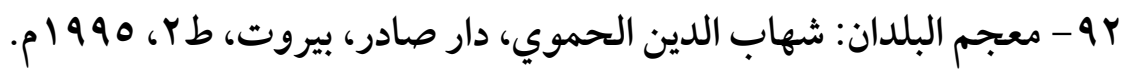
به - معجم مقاييس اللغة: أحمد بن فارس بن القزويني، تحقيق: عبد السـلام محمد هارون،

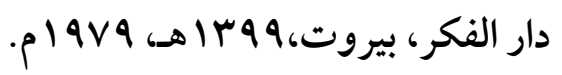
§ه - مفــاتيح الغيـبـ: الإمـام فخر الـدين الرازي، دار إحيـاء التراث العربي، بيروت، طس، .

ه 9 - مقاصــد الثــريعة الإسـلامية: الطاهر بن عاشـور التونسـي، تحقيق: محمد الحبيب ابن

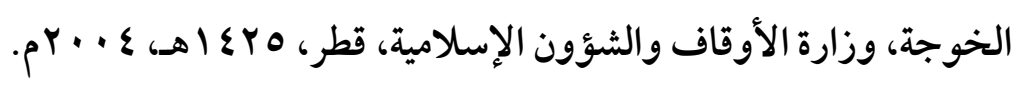
ج ه- مقالات الإسلاميين: أبو الحسن الأشعري، تحقيق: هلموت ريتر، دار فرانز شتايز، مدينة

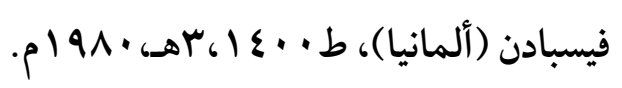
9V - مقدمة ابن خَلدون: عبد الرحمن بن خلدون، دار ابن خلدون، الاسكندرية، د.ت.

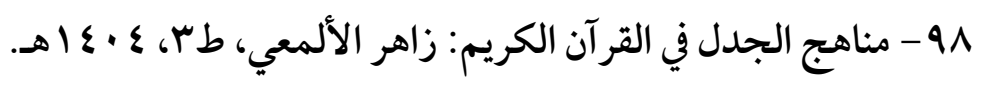
9 - منهاج السـنة النبوية: تقي الدين أبو العباس بن تيمية، تحقيق: محمد رشـاد سـالم، جامعة 


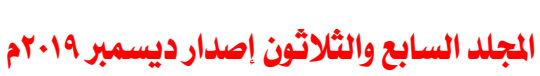

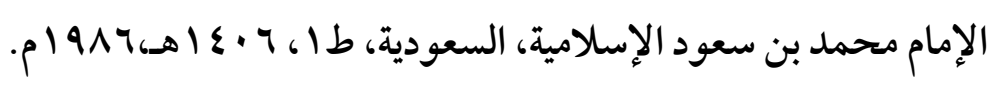

. . . - منهج الجدل والمناظرة في تقرير مسائل الاعتقاد: عثمان على حسن، دار إشبيليا للنشـر

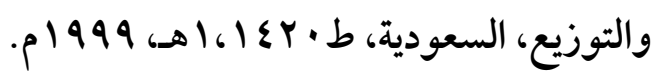
1 - 1 - نصــيحـة أهـل الحـديـث: أبو بكر الخطيـب البغـدادي، تحقيق: عبـد الكريم أحمـــ الوريكات، مكتبة المنار، الزرقاء، طا ، 1 • ع أهـ. r • 1 - نوادر الأصــول في أحاديـث الرسـول الرحمن عميرة، دار الجيل، بيروت، د.ت. r • 1 - وسائل علاج ظاهرة التَّكفير : عاصم بن عبد الله القريوتي، دار العلم، السعودية. ع · 1 - وفيات الأعيان: أبو العباس شمس الدين بن خلكان، تحقيق: إحسان عباس، دار صادر، 


\begin{tabular}{|c|c|c|}
\hline رقم الصفحة & المأوضوع & $p$ \\
\hline 1114 & 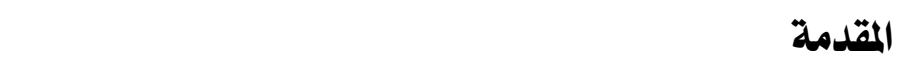 & 1 \\
\hline 119. & المبحث الأول: التعريف بالخوارج وفرقهم وأفكارهم & r \\
\hline 1191 & المطلب الأول : تعريف الخوارجونشاتهم & $r$ \\
\hline 1191 & الخوارج لغة واصطلاحًا & $\varepsilon$ \\
\hline 1191 & نشأتهم & $\bullet$ \\
\hline 1194 & المطلب الثاني ؛ ألقاب الخوارجوشرقهم & 7 \\
\hline 1191 & أولاً: ألقاب الخوارج الخاب & V \\
\hline $\mid r+1$ & 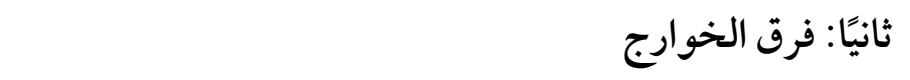 & $\wedge$ \\
\hline Ir.r & المطلب الثالث: المبادئ العاملة للخوارج & 9 \\
\hline ir.r & أولاً: الخروج على الإمام الجائر. & $1 \cdot$ \\
\hline$r r+\Lambda$ & 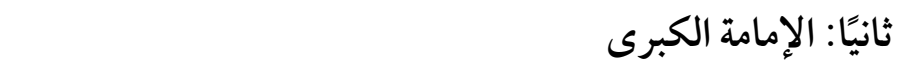 & 11 \\
\hline$|r|$. & ثالثًا: رفض التحكيم & ir \\
\hline$|r| \mid$ & رابعًا: تكفير مرتكب الكبيرة & ir \\
\hline IrIr & المبحث الثاني: أفكار الخوارج بين الماضي والحاضر & $1 \varepsilon$ \\
\hline IrIE & المطلب الأول ؛ ثاهرة التكثير & 10 \\
\hline irio & تعريف التكفير & 17 \\
\hline irir & أسباب ظاهرة التكفير & IV \\
\hline Irrr & الآثار المترتبة على التكفير & 11 \\
\hline IYYE & موانع التكفير & 19 \\
\hline IYYA & الخوارج وظاهرة التكفير & $r \cdot$ \\
\hline
\end{tabular}


المجلد السابع والثلاثون إصدار ديسمبر 19. Pr م م ب

\begin{tabular}{|c|c|c|}
\hline Irrr & كيفية علاج هذه الظاهرة & r) \\
\hline IrEY & المطلب الثاني ؛ ظاهرة الغلو & rr \\
\hline IrEY & تعريف الغلو & r \\
\hline IYEY & جذور الغلو ونشأته & $r \varepsilon$ \\
\hline iro. & 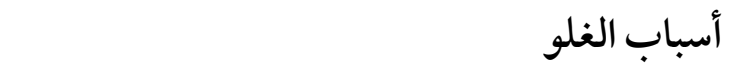 & ro \\
\hline Iror & الخوارج والغلو & ry \\
\hline Iry. & علاج ظاهرة الغلو & $r v$ \\
\hline Irmr & المطلب الثالثه ثاهرة الشدة والغلثة & $r \wedge$ \\
\hline IrmY & المطلب الرابع : ثاهرة الجدل وميلهم إليه وقوتهم ثيه & rq \\
\hline irry & المبحث الثالث: وسطية الإسلام & r. \\
\hline Irr & وسطية الإسلام & 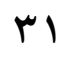 \\
\hline IrrA & أولاً: موقفه من ظاهرة التكفير & rr \\
\hline IYAE & ثانيًا: موقفه من ظاهرة الغلو & r \\
\hline IrAM & ثالثًا: موقفه من ظاهرة الشدة والغلظة & $r \xi$ \\
\hline Irar & رابعًا: موقفه من ظاهرة الجدل والميل إليه & ro \\
\hline 1799 & الخاتمة والنتائج & ד r \\
\hline $\mid r \cdot r$ & 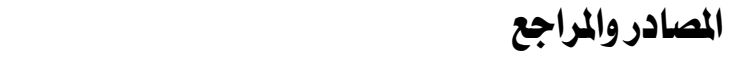 & rv \\
\hline Irir & 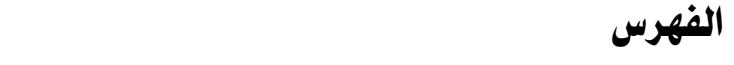 & $\mu_{\Lambda}$ \\
\hline
\end{tabular}




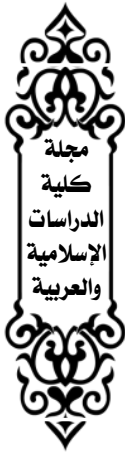

